UNIVERSIDADE DE SÃO PAULO

FACULDADE DE FILOSOFIA, LETRAS E CIÊNCIAS HUMANAS

DEPARTAMENTO DE LETRAS CLÁSSICAS E VERNÁCULAS

PROGRAMA DE PÓS-GRADUAÇÃO EM LITERATURA BRASILEIRA

STEPHANIE DA SILVA BORGES

O teatro político brasileiro e as diferentes faces do seu engajamento

Versão Corrigida

São Paulo 
STEPHANIE DA SILVA BORGES

O teatro político brasileiro e as diferentes faces do seu engajamento

\section{Versão Corrigida}

Dissertação de Mestrado apresentada ao Programa de Pós-Graduação em Literatura Brasileira do Departamento de Letras Clássicas e Vernáculas da Faculdade de Filosofia, Letras e Ciências Humanas, da Universidade de São Paulo, como parte dos requisitos para obtenção do título de Mestre em Letras (Literatura Brasileira).

Orientador: Prof. Dr. João Roberto Faria.

São Paulo 
Autorizo a reprodução e divulgação total ou parcial deste trabalho, por qualquer meio convencional ou eletrônico, para fins de estudo e pesquisa, desde que citada a fonte.

Catalogação na Publicação

Serviço de Biblioteca e Documentação

Faculdade de Filosofia, Letras e Ciências Humanas da Universidade de São Paulo

B 732t

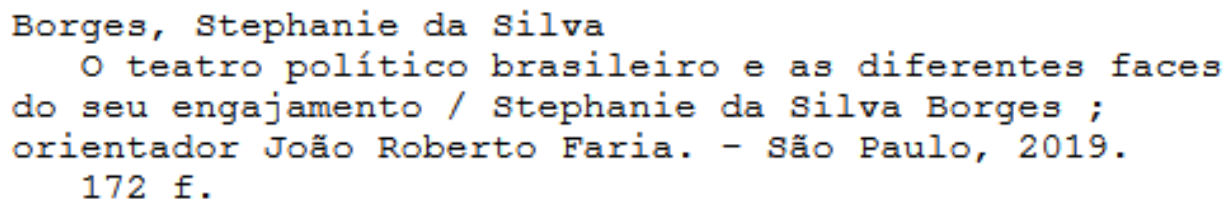

1. Teatro político. 2. Engajamento. 3. Teatro de Arena. 4. Teatro Oficina. 5. Ditadura. I. Faria, Joâo Roberto, orient. II. Título. 


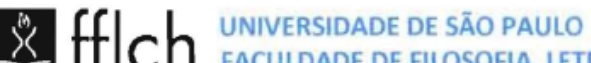

FACULDADE DE FILOSOFIA, LETRAS E CIÊNCIAS HUMANAS

\section{ENTREGA DO EXEMPLAR CORRIGIDO DA DISSERTAÇÃO/TESE}

\section{Termo de Ciência e Concordância do (a) orientador (a)}

Nome do (a) aluno (a): Stephanie da Silva Borges

Data da defesa: 16/09/2019

Nome do Prof. (a) orientador (a): Prof. Dr. João Roberto Gomes de Faria

Nos termos da legislação vigente, declaro ESTAR CIENTE do conteúdo deste EXEMPLAR

CORRIGIDO elaborado em atenção às sugestões dos membros da comissão Julgadora na sessão de defesa do trabalho, manifestando-me plenamente favorável ao seu encaminhamento e publicação no Portal Digital de Teses da USP.

São Paulo, 04/11/2019

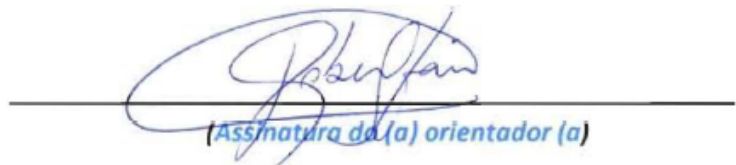


Este trabalho é dedicado às memórias de Augusto Boal e Gianfrancesco Guarnieri. 


\section{AGRADECIMENTOS}

Chegando ao destino final deste mestrado, vejo o quanto agradecer será insuficiente, tendo em vista toda a rede de suporte que tive. Escrever uma dissertação pode ser difícil e desgastante, ao menos para mim, há alguns anos afastada da vida acadêmica. De fato, este texto só existe graças à força de vontade que me obriguei a ter e à confiança e carinho das pessoas que me rodeiam.

Primeiramente, agradeço aos meus pais, Jubimara e Eduardo, pelo apoio em todos os momentos, mas principalmente por me ensinarem o gosto dos livros e por sempre terem me proporcionado as condições e o incentivo aos estudos - da graduação à França, da segunda graduação até São Paulo.

À FFLCH e à USP, pela afetuosa receptividade e enorme contribuição para minha formação acadêmica, em termos de estruturação das minhas descobertas.

Ao Prof. Dr. João Roberto Faria, com quem o meu encontro foi de fundamental importância, pela orientação acolhedora e disponível (sem deixar de ser rigorosa e organizada), pelos estímulos intelectuais e críticos ininterruptos e pelos conhecimentos, convicções e confiança compartilhados durante os anos de pesquisa.

Ao CNPq, pela bolsa concedida, sem a qual a minha mudança para São Paulo teria sido impossibilitada.

Aos professores da banca - Maria Sílvia Betti, Luiz Fernando Ramos e Homero Vizeu Araújo -, que me honram por acompanharem o meu trabalho desde o exame de qualificação e/ou desde a Iniciação Científica, ainda na UFRGS, sempre com leituras generosas, avaliações críticas consistentes e considerações decisivas para o decorrer dos estudos.

Ao meu companheiro na viagem e no enfrentamento da vida, Octávio, um alicerce na jornada da pós-graduação e um grande parceiro de reflexão, que me inspira a dar valor às vitórias e ter força para levantar de eventuais derrotas.

Aos amigos (de São Paulo, de Porto Alegre e o de patas), por me oferecerem suas amizades reconfortantes, conselhos, trocas, ajudas solidárias, parcerias de pensamento e momentos de fôlego ao longo da trajetória do mestrado.

Aos alunos que tive o prazer de encontrar nesses poucos anos como professora, por me mostrarem a aprendizagem na prática de ensinar e abrirem meus horizontes.

Aos teatros Arena e Oficina, por suas obras e feitos tão necessários - a razão de tudo isso. 
A gente vai contra a corrente Até não poder resistir Chico Buarque. 


\section{RESUMO}

BORGES, Stephanie da Silva. O teatro político brasileiro e as diferentes faces do seu engajamento. 2019. 172 f. Dissertação (Mestrado) - Faculdade de Filosofia, Letras e Ciências Humanas, Universidade de São Paulo, São Paulo, 2019.

A presente pesquisa de mestrado tem como objeto de estudo o teatro político brasileiro do pós-64 (ocasião do golpe civil-militar) e suas consequentes ramificações no campo da esquerda, visto que, embora apresentassem finalidades aparentemente comuns dentro desta mesma tendência de oposição e, ainda, resistissem às arbitrariedades da censura ditatorial, alguns dos principais dramaturgos e grupos teatrais do período mencionado acabaram envolvidos em um interessante embate ideológico, pois a noção de engajamento ampliava-se na época - o conceito teve origem na esquerda; no entanto, apresenta muitas nuances. Portanto, sem esgotar noções teóricas de engajamento político ou literário em teatro, julga-se importante clarificar o termo com propriedade e não adotar integralmente as concepções dos autores da literatura engajada do pós-guerra, embora estes sejam considerados em suas perspectivas políticas, filosóficas e estéticas. Assim, tendo em vista o conceito como chave de leitura, pretende-se mapear o engajamento de duas companhias teatrais brasileiras politicamente atuantes na década de 1960, Teatro de Arena e Teatro Oficina, examinando detidamente as realizações de Arena Conta Zumbi (1965) e de Roda Viva (1967-1968).

Palavras-chave: Teatro político. Engajamento. Teatro de Arena. Teatro Oficina. Ditadura. 


\begin{abstract}
BORGES, Stephanie da Silva. Brazilian political drama and the different perspectives of its engagement. 2019. 172 f. Dissertação (Mestrado) - Faculdade de Filosofia, Letras e Ciências Humanas, Universidade de São Paulo, São Paulo, 2019.

The present research has its object of study in the political drama in Brazil post-1964 (when the civil-military overthrow) and its consequent ramifications in the left-wing field, since, although they had seemingly common left-winged purposes in the same opposition tendency and, yet, resisted to the arbitraries of the dictatorial censorship, some of the main playwrights and theatrical groups in the aforementioned period ended up involved in an interesting ideological clash, for the notion of engagement was expanded at the time - the concept was originated in the left wing; however, it presents many nuances. Therefore, without exhausting theoretical notions of political or literary engagement in drama, it is important to clarify the term properly, instead of fully adopting post-war engaged literature authors' concepts, even though they are considered in their political, philosophical and aesthetic perspectives. Thus, bearing in mind the concept as the reading key, one intends to map the engagement of two political active Brazilian theatrical companies in the 1960s, Teatro de Arena and Teatro Oficina, examining the performances of Arena Contra Zumbi (1965) and Roda Viva (19671968).
\end{abstract}

Keywords: Political drama. Engagement. Teatro de Arena. Teatro Oficina. Dictatorship. 


\section{SUMÁRIO}

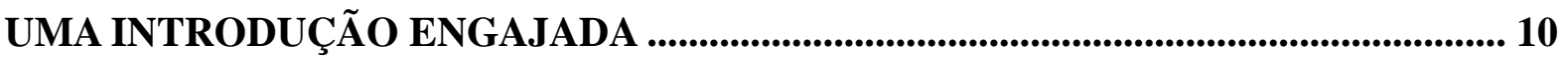

1 ONDE ESTÃO OS ENGAJAMENTOS? ................................................................................. 16

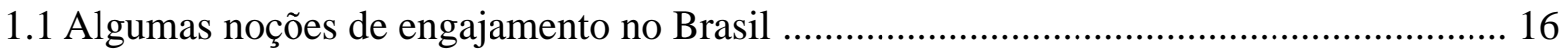

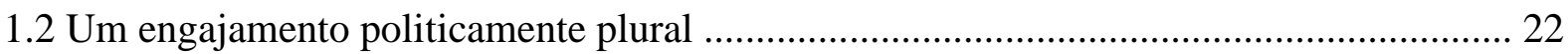

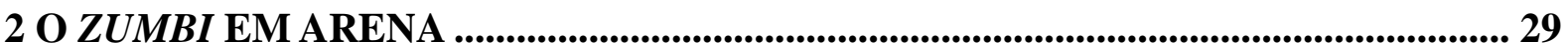

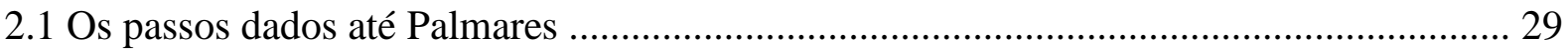

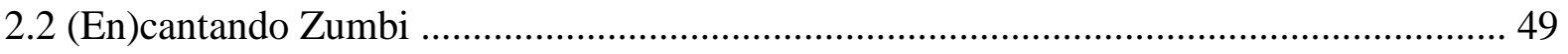

3 E EIS QUE CHEGA A RODA VIVA “OFICINEIRA" ......................................... 100

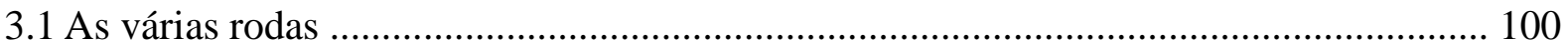

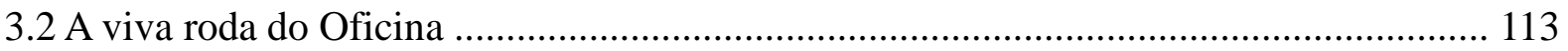

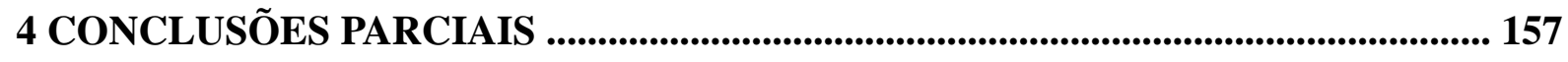

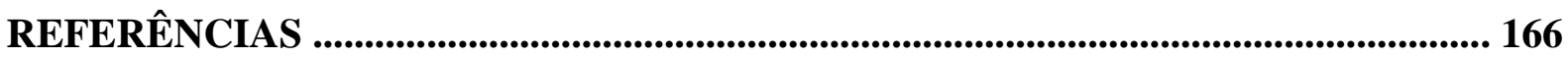




\section{UMA INTRODUÇÃO ENGAJADA}

Esta dissertação se propõe a analisar algumas respostas da arte de contestação à repressão, através de duas companhias teatrais, com o objetivo de aprofundar os estudos sobre o teatro político feito no Brasil à época ditatorial e suas diferentes formas de engajamento, pretendendo contemplar paralelamente distintos pontos de vista levados à cena. Para isso ser posto em prática, determinados elementos foram selecionados e problematizados ao longo da pesquisa: primeiramente, o próprio conceito de engajamento, compreendido como parte de movimentos culturais da época e, depois, dois grupos teatrais que representaram com excelência o espírito do período, se utilizaram de diversas maneiras dos trabalhos de seus autores e exploraram um tipo particular de engajamento intrínseco, concebendo duas atitudes perante o teatro, o que acabou ditando ideológica e esteticamente as suas dramaturgias e montagens de espetáculos, deixando importantes heranças até a contemporaneidade. Portanto, dentre os teatros que priorizavam o protesto contra o regime autoritário e/ou que começaram a tomar posição frente à perplexidade da cultura e da sociedade, o Teatro de Arena e o até então aliado Teatro Oficina se destacam, para além da presença do Grupo Opinião, a partir de 1964 - coligado, em parte, ao Arena e ao já esfacelado Centro Popular de Cultura (CPC), o Opinião foi o primeiro a responder ao golpe civil-militar.

De tal modo, houve uma tensão permanente entre tais perspectivas artísticas: o engajamento simpático com o público do Teatro de Arena, ao revisar a história nacional, e a exposição brutal da desagregação burguesa do Teatro Oficina, radicalizando a realidade. Consequentemente, refletiram-se duas correntes estéticas e políticas bem diferentes dentro da arte dita de esquerda, conforme enfatizou Schwarz (1978) na própria época, através de um relato feito "no calor da hora", o qual impulsionou o presente estudo - o pesquisador pensou o país em estado de apreensão, terminando por classificar as companhias referidas como antípodas. $\mathrm{O}$ argumento pode parecer duvidoso, à primeira vista, mas construiremos o seu sentido durante este trabalho.

Considerando o período específico da segunda metade da década de 1960, já após o estabelecimento da ditadura, fica claro que o Arena e a figura de Augusto Boal se guiavam mais pelo caminho do teatro engajado dito esclarecido, sendo contra a arte pela arte, os malefícios do capitalismo e, obviamente, o entretenimento preconizado pela direita (segundo alguns "arenistas", o Oficina e o Tropicalismo proporcionavam isso). Por outro lado, o Oficina, de José Celso Martinez Corrêa, de modo progressivo, se encantava mais pela linha irracional e se punha contrariamente ao didatismo ineficaz (pelo viés da educação popular), 
característico do teatro político de esquerda mais tradicional, a quem se mostrava um adversário violento.

Sendo assim, pretende-se adentrar os universos cênicos de Arena conta Zumbi (1965), de Gianfrancesco Guarnieri e Augusto Boal, peça que tomou como pretexto a história nacional ligada à escravidão para evocar outra suposta revolução - à luz do que se passava no presente, logo após o golpe -, e Roda Viva (1967-1968), com autoria de Chico Buarque, que escancarou os bastidores e a vida cruel do artista posto na indústria cultural, estendendo a crítica ao público em seu espetáculo, estreado no ano seguinte. Enfim, visa-se explorar, sobretudo, os respectivos engajamentos (políticos) dessas realizações, mas, também, os temas abordados por analogia, as concepções cênicas e textuais empregadas, as linguagens e as questões vanguardistas pertinentes ao momento, tais como as inovações proporcionadas no palco pelos "motivos para se fazer teatro" e as apropriações do texto teatral, porquanto a arte cênica tenha permanecido a serviço da esquerda desde antes do endurecimento do regime militar.

Além disso, é importante esclarecer que a pesquisa é modulada, principalmente, em torno das obras de Boal (texto e encenação) e de Zé Celso (encenação autoral). Então, para efeito de argumentação, na análise, não faz grande diferença o fato de o diretor do Oficina ter sido chamado separadamente para o trabalho em Roda Viva, no qual reescreveu no palco a dramaturgia de Chico Buarque sem o seu grupo, pois o espetáculo resultou em um carnaval ofensivo para militares e público em geral, ou seja, o engajamento, a concepção e o método utilizados não mudaram, são do Oficina. Entretanto, a independência não é totalmente irrelevante, como apresentaremos em pormenor ao estudar a montagem: nela, acoplados a algumas figuras do Oficina, novos atores cariocas deram corpo ao importante coro; consequentemente, isso deu origem a dois padrões de conduta no seio da companhia, provocando uma certa tensão no elenco e um posterior esfacelamento. A propósito, alguns atores foram se retirando do grupo após o processo de entrada do coro de Roda Viva, porque o irracionalismo teria tomado conta do coletivo.

Ainda, recorrendo à ótica de Prado (2009) para nomear teatro político como tal, podese afirmar que, no Brasil, o teatro com este caráter irrompeu durante a década de 1950 e ganhou força na de 1960, sobretudo em São Paulo, quando a dramaturgia brasileira estava na ordem do dia com peças e autores nacionalistas e, mesmo, militantes, refletindo o engajamento da cultura do período como um todo. Como se sabe, após o golpe de 1964, apesar da presença da censura sobre a arte, muito se tematizou contra a ditadura em cima dos palcos (teatrais e musicais), uns dos únicos lugares onde ainda era possível expressar opiniões 
e fazer resistência à repressão, evidentemente, com cautela e apoio do público. Desse modo, pode-se projetar que a nossa dramaturgia política se difundiu especialmente no período de dez anos nos quais se afirmou o paradoxo "schwarziano" entre o autoritarismo político da direita e o questionado domínio cultural da esquerda, de Eles Não Usam Black-Tie, texto e espetáculo “popular” do Arena, de 1958, até a montagem “oficineira” de Roda Viva, em 1968.

Nesse sentido, os contatos atuais com a historiografia do teatro político nacional podem se efetivar pela pluralidade da cultura esquerdizante, a qual deixou legados e realizou um extrapolar de limites especial: por exemplo, as peças a serem visitadas a seguir não são as mais teorizadas dos seus respectivos grupos, mas, guardadas as relevâncias, elas se tornaram ações reveladoras de duas tomadas de posição com potencial para serem classificadas como políticas, hoje em dia, conforme até o momento se viu - em um dos textos, há a nova forma dramática posta em prática pelo Arena (didaticamente expondo a história de uma resistência libertária), e, no outro, temos o segundo sopro revolucionário do Oficina (mostrando o caráter autêntico de seu encenador, marcante mesmo fora da companhia).

Por conseguinte, não se faz necessário propor uma abordagem demasiado histórica do teatro político nesta dissertação, uma vez que isso já foi realizado com excelência pelos críticos Décio de Almeida Prado, Yan Michalski e Sábato Magaldi, pelo orientador deste trabalho, João Roberto Faria, por revistas como a Dionysos e por historiadores da cultura, como Marcos Napolitano e Marcelo Ridenti - apenas para citar alguns exemplares, entre outros materiais indicados na bibliografia. Ademais, há um panorama histórico do teatro dos anos ditatoriais em meu Trabalho de Conclusão de Curso, concebido em 2012 no Instituto de Letras da Universidade Federal do Rio Grande do Sul, intitulado "Machado e Chico: dois dramaturgos no espelho da história". Fora isso, julga-se importante lembrar que o assunto “Arena e Oficina”, em geral, foi bastante estudado; porém, não com o horizonte adotado aqui: além de ter selecionado obras não tão visadas como foram Show Opinião, Arena Conta Tiradentes e $O$ Rei da Vela, esta pesquisa busca certa originalidade em percorrer as diferenças da esquerda artística no início do regime militar.

Assim, justificando a escolha dos temas e adiantando a problemática de um dos lados estudados, é imprescindível encararmos o Oficina enquanto uma companhia de esquerda, embora o grupo seja logicamente muito questionado pela esquerda mais tradicional. E por que essas críticas, então mútuas entre as companhias, passaram a existir no cenário teatral? Quais eram os graus distintivos de engajamento no fazer teatral, quanto à parte prática? Quando eles começaram a surgir (lembrando que Zé Celso e Boal já haviam trabalhado juntos anteriormente ao golpe de 1964) e como se manifestaram nos espetáculos e textos escolhidos 
aqui? Por que os dois diretores não partilharam mais as suas principais ideias a partir daqueles anos pós-golpe? Esses são alguns questionamentos a serem seguidos, encaminhando as argumentações exploradas até a reflexão final. Então, através de um texto autoral e musical do Arena e outro pertencente a um dramaturgo ainda incipiente (como Chico Buarque era na época), apropriado pelo líder do Oficina, considerações sobre as montagens e suas recepções também são importantes para avaliar o caso.

Geralmente, tende-se a enxergar a esquerda política com um só contorno - e a artística mais ainda -, apesar de hoje sabermos da existência de várias vicissitudes dentro de um movimento, consolidadas cada vez mais após as eleições de 2014 e o golpe de 2016, vinculado ao impeachment da presidenta Dilma Roussef. Contudo, quando olhamos para o passado, a tendência ao bloco nos assalta: artistas na luta armada, empenho com base na união e arte panfletária são alguns dos chavões; todavia, os engajamentos, mesmo sendo políticos, não funcionam todos da mesma maneira. Dessa forma, ao refletirmos sobre o Teatro Oficina atual, depois da sua reabertura (Teatro Oficina Uzyna-Uzona), não é problemática a afirmação de que o grupo é claramente politizado e engajado na esquerda, mesmo sendo discutíveis os seus enlaces episódicos com a indústria cultural ocorridos com o tempo. No entanto, se pensarmos no Oficina antes do seu fechamento de 1974, não seria possível classificá-lo tão de imediato, o que é um impasse importante para o presente trabalho: Zé Celso e seu conjunto de artistas não se consideravam propriamente engajados, mas sim à margem da esquerda; nesse sentido, não costumamos dirigir - nem negar - o conceito de engajamento a teatros como o Oficina (mais violento e radical), que foi desenvolvido no contrapé do Arena (mais imiscuído em dramaturgia e política), montou famosas obras estrangeiras até 1966 e, posteriormente, se ligou às vanguardas, colocando-se em um viés diferente ao do teatro político tradicional ou mais pedagógico, isto é, posicionando-se não fora dessa esfera, mas em uma evolução da resistência teatral, dentro da qual oferecia uma nova maneira de contestar o status quo. $\mathrm{O}$ Arena - não esqueçamos, também criticado pelo militante CPC por ser mais empresa do que agente de uma cultura popular -, quando concebeu os musicais, igualmente contestou a situação política, querendo dar uma resposta certeira ao golpe civil-militar; já o Oficina, com o seu conhecido desbunde, acusou as classes médias, tomando uma outra atitude em relação ao que estava posto pela sociedade enquanto valores (família, casamento, entre outros), propondo, dessa forma, uma maneira diferenciada de se opor à ditadura e ao sistema políticoeconômico vigente.

Ao mesmo tempo, de início, visa-se mostrar algumas formas pelas quais o conceito de engajamento já foi pensado, e, nesse caminho, ao nuançar os seus sentidos, o estilo do Oficina 
poderá ser tranquilamente chamado de engajado, não somente pelo fato de a sua arte não ser desengajada, alienada ou adepta da "arte pela arte" (política à sua maneira, se desamarrarmos o argumento), mas porque a companhia vai além disso, sendo teoricamente "infectada" por ideias comunistas (vide alguns de seus membros, militantes do temerário Partido Comunista Brasileiro, o PCB, e o seu repertório, composto por obras russas) e politicamente críticas, muitas vezes, dos mesmos alvos que a esquerda restante, como a burguesia progressista, o país militarizado e o capitalismo imperialista. Logo, ambos os pontos de vista demonstraram uma arte que toma partido, contestadora e engajada na sua realidade social, unicamente apresentando os problemas não do mesmo modo, utilizando linguagens cênicas contrastantes e tornando rico o debate ${ }^{1}$.

Portanto, ao incluir os dois teatros no polo da arte política de protesto (que faz algo a respeito do estado das coisas vivenciadas), busca-se explorar essas abordagens através das peças escolhidas - uma de autoria, outra de apropriação ressignificante -, a serem lidas e relacionadas com o conceito expandido. Este, por sua vez e no caso desta dissertação, teria a ver com todo tipo de teatro que procura passar uma mensagem, principalmente de viés político: seja o CPC da UNE, com as peças de agitprop; seja o Arena, nos musicais; seja todo o teatro voltado ao nacional-popular; ou ainda, o caminho explosivo tomado pelo Oficina a partir de 1967, acentuando a cisão na esquerda e os diferentes caminhos tomados. No fim das contas, a questão é discutir como os grupos transmitiram "algo", pois um teatro político, fundamentalmente, convence o espectador de alguma coisa - que o capitalismo é injusto, que o sistema de governo é cruel, que devemos nos levantar das cadeiras, entre outras coisas.

Por fim, é importante salientar as etapas do processo: ao focalizarmos o teatro político associado ao conceito plural de engajamento, a ideia imediatamente seguida, no Capítulo 1, é a de expor brevemente algumas noções teóricas sobre o termo (conectadas ao fazer literário e/ou teatral), de acordo com alguns pensadores do século XX, finalmente apresentando uma ideia própria a ser ponderada durante as análises posteriores das peças. É forçoso ressaltar ainda que, após modular o termo engajamento para trabalhar com as vozes envolvidas, não se aplicará o conceito, propriamente dito, aos espetáculos, mas se testarão as possibilidades

\footnotetext{
${ }^{1}$ Trazer o trabalho de Zé Celso junto da palavra engajamento poderia constituir um problema, porque há quem veja no boom do Oficina uma vanguarda conservadora, representada pelo espetáculo O Rei da Vela; portanto, o diretor não seria alguém que faz uma produção à esquerda, podendo, ao contrário, ser acusado de transformar o teatro e suas batalhas em mercadoria, conforme acontecera com o Show Opinião. Assim, tendo em vista que o conceito se liga, mais diretamente, a um pensamento de esquerda, como caracterizar a montagem de Roda Viva com esse termo? Antes, $O$ Rei da Vela provocou uma reviravolta na esquerda, e Zé Celso, até então considerado um aliado, quando o montou, não concordou com o pensamento esquerdista, polemizando-o e forçando-o a fim de também atingir os costumes sociais. Em consequência, lidaremos com isso, que não é "tudo a mesma coisa", usando as nuances da palavra engajamento, as quais nos permitem estendê-la.
} 
desses trabalhos a partir deste ponto de vista. Por conseguinte, nos Capítulos 2 e 3, expor-seão os estudos realizados sobre as companhias selecionadas e suas respectivas peças e montagens, enfatizando as ideias de base crítica dos grupos e as apreciações dos textos escolhidos, visitando os “engajamentos antípodas". Para isso, o olhar sobre os objetos partirá da perspectiva da recepção, por um levantamento de críticas especializadas e depoimentos sobre a época, além de pesquisas precedentes a esta - um cotejo feito sem exaustão, contando com contribuições teórico-críticas primordiais e de referência, empregadas para moderar o paralelo. Finalmente, através dos dois diretores centrais, a dissertação exibirá conclusões parciais acerca das políticas levadas a cabo pelos seus teatros, tais como trazidas no corpo do texto então apresentado. Afinal, quais elementos estas obras teatrais exibem para serem consideradas engajadas?

Por último, sabendo que as mensagens artísticas mais diretas à ditadura civil-militar de um esquerdismo "suspeito, conservador e atrasado", como disse o tropicalista Caetano Veloso em entrevista à Rede Globo, em 2018 - também postas em prática pela cultura, não eram exatamente as cenas causadoras de maiores incômodos sociais, tudo se resumirá no modo pelo qual a investigação será conduzida, levando em conta as ideias de engajamento apresentadas (usadas como chave de leitura) e onde isso pode estar presente: nos textos, nos espetáculos e nas posturas. 


\section{ONDE ESTÃO OS ENGAJAMENTOS?}

\subsection{Algumas noções de engajamento no Brasil}

Retomando os argumentos da introdução exposta acima, ao pensar no período cultural envolto pela ditadura civil-militar e nas diferentes relações com o público, postas em prática pela arte de esquerda, pode-se afirmar que não houve uma simples contrariedade entre as políticas do Teatro de Arena e do Teatro Oficina, mas uma evolução do estado de engajamento em suas produções.

É sabido que as artes do espetáculo (teatro, cinema e música) estiveram à frente da vida cultural brasileira na época de "relativa hegemonia cultural da esquerda no país", enfatizada por Schwarz (1978, p. 62) em um conhecido ensaio; advindo do teatro de esquerda o primeiro grupo - o Opinião - formado para protestar contra a ditadura, regime que pôs as liberdades em suspensão. Assim, liderados pela arte dramática, conforme Gomes (1968, p. 7), os movimentos artísticos passaram a incomodar quem detinha o poder.

Ainda na década de 1950, perante o predomínio do capitalismo, a tomada de consciência política do nosso subdesenvolvimento provocou o surgimento de inúmeros artistas de esquerda, ligados ou não ao Partido Comunista e à militância, que já produziam obras socialmente preocupadas - essa consciência do subdesenvolvimento gerou uma literatura engajada. Como ratificação, Candido (1989) mostra a ideia da consciência política do escritor da época em relação a problemas que os indivíduos de esquerda queriam ver superados no Brasil. No teatro, a pluralidade de tendências cedeu à reflexão da temática social nacional; no entanto, a reação aos anos 40 não foi primeiramente ideológica, mas barateadora e experimental, através do nascimento do Teatro de Arena. Nele, o clima eufórico do desenvolvimento juscelinista e a ascensão de um pensamento de esquerda se fizeram sentir quando Augusto Boal retornou ao Brasil e se juntou ao grupo, recém fundido ao Teatro Paulista do Estudante (TPE, comprometido com ideias políticas de esquerda), e passou-se a discutir o teatro esteticista e burguês do Teatro Brasileiro de Comédia (TBC) - as origens do Arena serão revisitadas durante esta dissertação. Logo, a presença da realidade brasileira na produção do nosso drama do século XX, identificada e preocupada fundamentalmente com as parcelas mais baixas da população (representação de tipos e costumes populares), surge associada a um nacionalismo realista e crítico, o que leva o teatro à vontade de militar na luta pela solução do atraso do país, propiciando "um caráter político e programático" à arte, como 
dizem Maciel e Andrade (2005, p. 9). Assim, o debate entre conteúdo próprio e forma adequada vinha à pauta antes do advento do Arena.

Com Eles não usam black-tie, peça que inaugurou o ideário nacional-popular (advindo do PC) nos palcos brasileiros e o nosso teatro político enquanto sistema, finalmente se pôs em cena a vida difícil do operário brasileiro, pertencente à classe dita inferior. $\mathrm{O}$ drama de Gianfrancesco Guarnieri, apesar de idealista, foi um estímulo para as melhores condições de produção e para o ganho de audiência, dado o seu sucesso, também fomentando a afirmação de jovens dramaturgos, atores e diretores - ao redor do Arena, eles estavam empenhados na construção de uma necessária e consistente dramaturgia político-social, com linguagem e interpretação brasileiras -, o que coincidiu com a etapa do nacionalismo político. Dessa maneira, segundo Maciel e Andrade (2005, p. 10-13), o teatro centralizado no povo ganhou espaço por meio de artistas inquietos com a situação e de obras que buscavam a perspectiva das camadas populares como ponto de vista e de partida para a criação cênica, tornando as bilheterias atrativas e organizando uma cultura nacional-popular em torno disso.

Conforme Napolitano (2001, p. 104), estando em vigor uma cultura esquerdista e nacional-popular, de aliança entre povo e artista, houve "uma mudança estrutural na linguagem" artística dos espetáculos e tal transformação contribuiu para uma renovação na estrutura da recepção, com um público “jovem, universitário, de esquerda”. Como enfatiza Gomes (1968, p. 12), este veio a se tornar maioria em nossos teatros políticos, incentivando a criatividade e as experiências artísticas no terreno do engajamento, além de ser economicamente benéfico:

\begin{abstract}
Minha tese central é que o conceito de engajamento artístico de esquerda, a partir do final dos anos 50, deve ser pensado a partir dessas mudanças estruturais no campo artístico-cultural como um todo, processo que diluiu a "república das letras" em outras áreas artísticas, vocacionadas para o "efeito", para a performance, para o "lazer". Assim, o conceito de engajamento, tal como delimitado por Sartre - a atuação do intelectual através da palavra (articulada em prosa e ensaio), colocada a serviço das causas públicas e humanistas -, sofreu no Brasil (e em outros países, sobretudo da América Latina) uma releitura, com todos os problemas e virtudes daí decorrentes. Ao contrário do que defendia o filósofo francês, o espaço de atuação privilegiado do artista/intelectual de esquerda brasileiro não foi a prosa ou o ensaio, embora os anos 50 e 60 fossem pródigos também nesses gêneros, mas as artes que apelavam aos sentidos corpóreos, através de imagens, sons e ritmos. (NAPOLITANO, 2001, p. 104)
\end{abstract}

O dinamismo de públicos, formas e conteúdos revela que o teatro engajado dos anos 60 foi extremamente produtivo, atuando politicamente, apesar da censura marcante em pelo menos metade da década. Desse modo, focalizando o lado social, a dramaturgia se agitou ao 
acompanhar o clima de radicalização política do país: o governo de João Goulart dava forças à esquerda, embora o PC ainda estivesse posto na ilegalidade, enquanto o teatro se colocava a serviço direto da conscientização das faixas populares, por exemplo, através das experiências do Centro Popular de Cultura (CPC) da UNE, criado no início da década, onde entravam o didatismo político e a revolução social, via resistência e panfleto. Após o golpe de 1964, com perseguições à esquerda e alguma censura, a arte cênica, identificada pela ditadura como simpática ao antigo regime, ficou sob ameaça, agindo dentro de uma pequena e controlável zona de liberdade: era-se complacente, porque o teatro agia sobre uma plateia reduzida e não imediatamente nas massas; entretanto, os sucessivos êxitos de público e a repercussão dos espetáculos advertiram as autoridades que limitavam a liberdade artística, culminando na primeira onda de repressão contra a arte da época (GOMES, 1968, p. 9).

Deve-se considerar, ainda, o caráter do ato político-social de uma representação por si só, pois toda e qualquer escolha leva o artista a ser participante, a tomar uma posição, como defende Gomes (1968, p. 10), que enfatiza a relevância do teatro diante da ditadura:

\begin{abstract}
Tôda escolha importa em tomar um partido, mesmo quando se pretende uma posição neutra, abstratamente fora dos problemas em jôgo, pois o apoliticismo é uma forma de participação pela omissão. Pois esta favorece o mais forte ajudando a manter o status quo. Tôda arte é, portanto, política. A diferença é que, no teatro, êsse ato político é praticado diante do público. "Essa a característica essencial da função dramática: ela acontece. É presente, não passado. [...]" Êste caráter de ato políticosocial da representação teatral, ato que se realiza naquele momento e com a participação do público, não pode ser esquecido se quisermos entender por que coube ao teatro um papel destacado na luta contra o status quo implantado em abril de 64. O teatro era, de tôdas as artes, aquela que oferecia condições para uma resposta imediata e mais comunicativa. Era também a que possibilitava ao povo, tão insatisfeito quanto os autores e participantes dos espetáculos, desabafar a sua insatisfação, "lavar a alma", desalienar-se.
\end{abstract}

A luta da classe teatral resistente se intensificou em 1965, sob dura censura e com tomadas de posição coletivas, atingindo o auge em 1968, através de greves e manifestações de repercussão - Gomes (1968, p. 12) diz que a arbitrariedade levou até mesmo a uma autocensura de autores e produtores. Opondo-se à ameaça à integridade do teatro, de acordo com Gomes (1968, p. 13), havia a "compreensão da responsabilidade histórica do artista e da função social da arte", comum à nossa nova dramaturgia e importante para o pensamento de que a liberdade é imprescindível na criação de uma obra, devendo o artista cultivá-la em todas as circunstâncias, dentro ou fora de cena. Porém, o medo chegou ao final desse ano de AI-5, relegando grande parte do teatro apenas para a diversão da classe média (com a exceção de 
quem conseguia metaforizar espetáculos e seguir na denúncia), porquanto faltavam clima favorável e liberdade de expressão.

Nesse caminho, segundo indica Napolitano (2001, p. 104-106), a presença de novos segmentos sociais na recepção e a urgência de se construir popularidade aos artistas de esquerda, instalada desde a passagem aos anos 60, ajudariam a realizar os objetivos políticos próprios ao engajamento - o mercado foi um dos caminhos à popularidade da arte engajada, que, depois da homogeneidade inicial, especificou sua audiência conforme cada ramo artístico -, por meio da consolidação de um grande público (imediato, frequente, fiel e ideologicamente próximo) e da ampliação de "circuitos de mercado", o qual se visava profissional e de massa sem desaguar na indústria cultural, agindo sobre o meio estudantil e o popular. Igualmente, Napolitano (2001, p. 109) ressalta que uma parte importante da nossa arte engajada buscou estrategicamente as $\operatorname{massas}^{2}$; por outro lado, a conquista dos jovens e o limite das classes médias garantiam a identificação entre palco e plateia, sendo esta empática à cultura nacional-popular, que "implodiu” entre 1967 e 1968, como o público:

\begin{abstract}
Paradoxalmente, após 64, o teatro de esquerda, marcado por esse espírito cívico de protesto/resistência e pela busca de encenação do otimismo e da crítica da "cultura popular", ampliará seu público, sobretudo entre os mais jovens, potencializando um processo histórico já notável no final dos anos 50. [...] Mesmo enfatizando a "cultura popular" e criticando algumas ilusões políticas da aliança de classes defendida pelo PCB (como a crença na "burguesia progressista"), o teatro de esquerda pós-golpe (Arena e Opinião, sobretudo) ainda manteve a perspectiva básica da "frente" política derrotada em 1964. Até um certo momento, por volta de 1966/1967, seu público fiel parecia homologar essa opção. (NAPOLITANO, 2001, p. 110)
\end{abstract}

Sobre a época, Napolitano (2001, p. 105-106; 121-122) e Gomes (1968, p. 11-12) asseguram que as principais pressões políticas e econômicas sobre o teatro vinham do controle exercido por um público pequeno-burguês, visto que a necessidade de agradá-lo era uma condição para a arte, mas da qual ela também podia se retirar por uma responsabilidade cultural e histórica; assim, uma nova reestruturação se deu na recepção após o nacionalpopular, a partir de 1967, com o teatro indo contra a plateia da camada média, problematizando esse projeto de educação e assinalando a crise na assistência da arte engajada, ocorrida entre 1965 e 1968. Aliás, parte desse público "aprovou” o teatro de esquerda

\footnotetext{
${ }^{2}$ Contra o militarismo imposto, determinados trabalhos artísticos políticos, como os do teatro operário, do Arena, do Oficina, dos CPCs e do Opinião (em alguns, podemos perceber continuidades, muito em função das posições e contribuições de Oduvaldo Vianna Filho), confirmaram a existência de um movimento a partir do qual fazer teatro popular ou alternativo significava assumir uma posição inversa ao teatro comercial (ou teatrão), como diz Paranhos (2017, p. 197-199): nisso, muitos artistas se vinculavam à indústria cultural, enquanto outros buscavam o exílio ou resistiam à modernização industrial - no último caso, periféricos e intelectuais se articulavam a novos movimentos sociais (formados sob a repressão, por sindicatos e comunidades) a fim de pensar a arte de maneira diferenciada.
} 
brasileiro de traços antiburgueses, inclusive aceitando ser agredido por ele - a radicalidade disso habita as peças violentas de José Celso Martinez Corrêa, que, como veremos, por vezes, provocaram mais incômodo do que consciência política ou a desejada tomada de atitude da plateia, mesmo tendo aberto novos rumos pelo rompimento de convenções proposto (GOMES, 1968, p. 12).

\begin{abstract}
$\mathrm{Na}$ medida em que a radicalização política tomava conta da vida nacional, o teatro iniciava um debate que iria explodir no final da década de 60, lastreado por novas questões: para quem se deve encenar? Para o "povo" ou para a "pequena burguesia", público tradicional dos teatros desde o final dos anos 40? Como devem ser trabalhados os dilemas nacionais? Pela emoção, catarse e identificação entre público e palco? Ou pela busca do distanciamento e do choque com a platéia? (NAPOLITANO, 2001, p. 109)
\end{abstract}

De tal forma, "a nova radicalização política", juntamente com uma cisão na intelectualidade esquerdista e uma mudança no meio estudantil - o teatro seria esmagado por essas transformações - finalizou a implosão relativa ao público em 1967, antes da promulgação do AI-5, não sendo este um processo consciente, mas concernente à "construção de uma sociabilidade de esquerda", segundo Napolitano (2001, p. 110-111), que também aponta o fato de a esquerda "hegemonizada" (em torno do PCB) ter se fragmentado a partir disso e a juventude ter se dirigido para uma contracultura; nessa linha, dentre as duas propostas dramatúrgicas mais expressivas desse fim de década, teríamos: o Oficina (sensivelmente crítico à política e à ideologia do partido) e o TUSP (possuidor de uma dramaturgia de resistência e apologia à luta armada), os quais, no final dos anos 60 , vieram a se articular contra a dramaturgia advogada pelo Partidão, ligada ao conceito de "nacionalpopular". Como explica Napolitano (2001, p. 111), os impactos de 1968 desarticularam as certezas sociais e ideológicas de um público coeso e crescente, até mesmo afastando a burguesia dos espetáculos, uma vez que a ousadia da forma, importante para uma renovação teatral, forçava os limites de gosto e assimilação dessa plateia "média".

Ainda, é importante lembrar que, como arte e política se relacionam, o teatro brasileiro muitas vezes esteve preocupado com a função política da arte, algo que Gomes (1968, p. 13) diz não ser contemporâneo e nem uma submissão dos autores esquerdistas a orientações partidárias, mas associável ao engajamento. Logo, no sentido de Landsberg (apud GOMES, 1968, p. 15):

O que denominamos engajamento é o assumir concreto da responsabilidade de uma obra a ser realizada no futuro, de uma diretriz definida para o esfôrço que dirigimos à formação do futuro humano. Conseqüentemente, é o engajamento que realiza 
nossa historicidade humana e querer subtrair-se a êle representa, em geral, a destruição do próprio progresso de nossa qualidade humana.

A qualidade humana (engajada) apontada acima, oposta a uma neutralidade artística, estaria presente na nova dramaturgia do pós-64, inclusive naqueles autores que se afirmavam não engajados, mas que, com conhecimento e denúncia da realidade brasileira, mostraram o contrário, assumindo uma posição (GOMES, 1968, p. 15). Sendo assim, Landsberg (apud GOMES, 1968, p. 16) defende que a qualidade do ato de engajar-se o torna total e livre - o engajamento seria posto em prática pelo "homem integral", possuidor de inteligência e vontade, e constituiria uma decisão pessoal, na qual se "toma consciência de sua responsabilidade”. Então, para Gomes (1968, p. 16), o artista, ao se engajar, não abre mão da sua liberdade e, ao invés disso, a ganha de vez, pois ela é um ato e não um estado, exercido integralmente e continuamente. Essas alegações dialogam com a ideologia de Jean-Paul Sartre, a ser visitada mais à frente neste texto.

Portanto, o atributo engajado do pecebista Dias Gomes, que escreve os acontecimentos enquanto os vivencia, talvez não possa ser efetivo em grupos como o Oficina; no entanto, Gomes (1968, p. 16) julga importante dizer que isso seria uma condição de conhecimento e de expressão da verdade, não um obstáculo a ela. O dramaturgo ainda traz Landsberg (apud GOMES, 1968, p. 17) para afirmar: "O engajamento em uma causa histórica que encarne determinados valôres, longe de ser um obstáculo ao conhecimento, ou de manter-se alheia a êle, é, ao mesmo tempo, uma necessidade da vida moral e um meio indispensável ao próprio conhecimento". Desse jeito, o seu sentido de engajamento, seja na militância geral ou em partidos, definiria um intelectual autêntico da época, uma vez que o não engajamento, a neutralidade da arte pura (também passível de ser encarada como um posicionamento político, numa outra perspectiva), não nos dá a certa percepção de valores e deixa verdades incompletas. Nesse viés, conforme Gomes (1968, p. 17), os novos autores, adotando o teatro como um meio de conhecer e refletir sobre a realidade, chegaram ao engajamento e contribuíram com a ideia de que a arte precisa de liberdade (na vida e no pensamento): para se engajar, o nosso teatro político passou pela etapa de enxergar o teatro enquanto ato de conhecimento.

As discussões acerca da arte política e do teatro engajado, muitas vezes avizinhadas, se efetivaram durante o século XX. Visto isso, a seguir, objetivando visitar um termo carregado de significados e justificar a sua vinculação aos dois diferentes espetáculos e grupos a serem visitados posteriormente, a seção seguinte versará especificamente sobre o 
engajamento para que se perceba as suas nuances, trazendo, no entorno, a ótica de teóricos que discutiram de diversas formas o conceito no processo do engajamento literário.

\subsection{Um engajamento politicamente plural}

A partir das considerações esmiuçadas anteriormente, exporemos um juízo próprio de engajamento em teatro a fim de relacioná-lo mais livremente às análises a serem feitas nos próximos capítulos.

Vimos que teatro político e engajado foram itens excitantes de debates em um período específico. Em geral, sabe-se que o engajamento ligado à literatura (ou ao teatro, no caso deste trabalho) diz respeito a uma criação ou prática diretamente entrelaçada com a política e, dentro disso, corresponde à manifestação de tomadas de posições, diálogos sociais e combates implicados nesse cenário. Logo, um autor engajado faria política na e através da sua arte, como defende o pesquisador Denis (2002). Entretanto, podemos levar em conta o fato de a militância - talvez uma expressão mais apropriada para esta tendência explícita - às vezes divergir do engajamento.

Historicamente, um conhecido modelo de teatro engajado adveio da Revolução Russa. Portanto, o teatro de agitprop já era engajado, segundo o compreendemos. Todavia, como é sabido, a noção foi formulada mais amplamente somente no pós-guerra por Jean-Paul Sartre, para quem, acreditamos que acertadamente, a ideia de responsabilidade foi fundamental, pois um indivíduo deve se responsabilizar pelo que fala e preconiza em liberdade, exercendo-a. Sendo o francês o pensador do engajamento mais referenciado até hoje, ele nos deu uma completa e pioneira explicação teórica sobre a palavra e a prática do artista engajado, apesar de, por vezes, ter adotado um suposto dogmatismo, conduta incansavelmente contestada ou, por outro lado, acatada e debatida, ao ser tratada por pensadores posteriores.

Para o existencialista Sartre (2015), concentrado em questões de quê, como, quando e para quem, o objeto substancial da literatura é o seu conteúdo e é forçoso remeter o significado da prosa (única arte que propõe e permite o engajamento, chamada de "império dos signos") para a realidade externa à obra artística. Com isso, o filósofo argumenta que a literatura se relaciona com o seu autor, pois o ato de escrever é engajado por si só, sendo a literatura desencadeada pela ação da palavra: situado no seu tempo, o escritor precisa se engajar totalmente na escrita, porque lida com significados, intervindo na sociedade (as palavras são atos expressivos que a alteram) e conduzindo os leitores - um escritor livre escreve para homens livres, a relação estabelecida entre eles pelo livro é constituída em 
liberdade e com responsabilidade e, por fim, juntos ambos compõem os sentidos. Em suma, um autor escreve a fim de se posicionar frente à atualidade, desvendar o mundo aos homens, exercer liberdade (necessária à criação) e se engajar por ela - também incluindo a liberdade do leitor, visto que a escolha tocante a este determina a seleção do tema sobre o qual escrever, devendo este leitor, igualmente, se engajar por inteiro, completando a obra. O engajamento sartriano seria, então, desde a imersão do escritor em si e em sua realidade histórica, até, dentro disso, a exposição do mundo para os seus contemporâneos através da instrumentalização da linguagem e do exercício da liberdade, levando a recepção à consciência da sua situação. Por excelência, o engajamento existiria em uma sociedade sem classes (sem autoritarismos e estabilidades); porém, como isso não é viável, quem escreve deve gerar uma arte engajada por meio de algumas medidas de literatura da praxis, como: angariar mais público real, principalmente entre operários, desvencilhar-se das raízes burguesas e ir contra o Partido Comunista, que pode diminuir a sua liberdade.

Isso posto, objetiva-se, aqui, fugir de uma definição simplista frequentemente proposta para a literatura e para o teatro engajados. Como foi dito, a arte engajada é uma arte que toma partido, contestadora e empenhada na sua realidade social; ou seja, não se conforma com o estado das coisas e intenta criticá-lo. No teatro, mais especificamente, o termo tem a ver com todo tipo de texto dramático e/ou espetáculo cênico que procura passar uma mensagem politizada ou política - algo conscientemente mais explícito -, estando os seus artistas filiados ou não a algum partido político (a política não é necessariamente partidária), antes adeptos ou contrários a alguma causa. Ainda, como o engajamento não é anacrônico, mas criação própria do século XX, principalmente do final dos anos 40 e início dos 50, foi gerado em uma situação específica e muito historicizado, ligado a uma época e a um tipo de arte, sobretudo de cunho político e esquerdista. Tendo isso em vista, é possível afirmar que o conceito é, por origem, de esquerda, e que, artisticamente, em nosso país, surgiu vinculado a um teatro de teor sócio-político, atento à sua internalização - forçando o argumento, a possibilidade de uma literatura se engajar à direita, ou melhor, ter funções em causas diversas, é admissível. Neste último caso, no entanto, não se costuma empregar o termo engajamento, propriamente dito, o qual deve estar no lugar certo, utilizado por agentes de esquerda. Consequentemente, a expressão "literatura empenhada", divulgada por Antonio Candido, seria um bom sinônimo. Outra opção é a "literatura de engajamento", expressão aproveitada por Denis (2002, p. 12), concernente a uma atividade trans-histórica, uma vez que sempre houve uma literatura defensora de princípios. No Brasil, a discussão artística aberta nos fins da década de 1950 e começo da de 1960 era entre engajamento e alienação: então, quem possuía consciência de 
subdesenvolvimento achava que a literatura deveria ir além, fazendo crítica social e se engajando.

Portanto, o ato de se engajar pode ser considerado uma adoção de posição ocorrida a partir de uma reflexão ou interferência crítica, tencionando romper com a situação dada para propor uma nova (até mesmo com relação à arte criada). Tal acontecimento não é incomum no teatro do período ditatorial brasileiro, o qual foi capaz de aproximar perspectivas diversas, como as abordadas na presente dissertação, que conceberam o engajamento e expuseram ideias ecoadas até hoje. Tudo isso se dá porque a arte demanda ações, atuações e atitudes aproximadas (politizadas, políticas, militantes e participantes), percepção esta que dialoga com o pensamento de Augusto Boal (2013, p. 13): “[...] todo teatro é necessariamente político, porque políticas são todas as atividades do homem, e o teatro é uma delas. / Os que pretendem separar o teatro da política pretendem conduzir-nos ao erro - e essa é uma atitude política". Assim, acredita-se que o teatro brasileiro de caráter político é, em si, integralmente envolvido com certos sentidos de engajamento, sendo praticamente impossível julgarmos esquerdista uma arte não tida como engajada.

A respeito da ligação do teatro político com o engajamento, temos, neste trabalho, ambos agindo mutuamente implicados; porém, pode haver um teatro de atribuições políticas e interesses mais inclinados para a direita, por exemplo. Entretanto, se deixarmos o viés puramente filosófico de lado (de predisposição do sujeito), o engajamento claramente se liga à esquerda, como é sabido; logo, para o senso geral sobre o engajamento na literatura, só seria engajado o artista de esquerda, comprometido com uma causa específica - ele faz da sua arte um instrumento de conscientização cujo horizonte é a revolução socialista. De mais a mais, no debate entre o teatro político e o engajamento, dissemos que a consciência do subdesenvolvimento brasileiro levou a uma arte engajada - isso em teatro, mas igualmente em literatura de prosa e poesia. Desse jeito, o drama, durante o século passado, passou a ser não somente uma maneira de encenação da realidade para simples entretenimento, indicando ser também uma vitrine de novos lugares e vozes políticas, como forma de interpretação do real. Ademais, é interessante salientar que, nos anos 50, 60 e 70, apesar da censura, a dramaturgia brasileira demonstrou uma ativa produção política, assentada em espetáculos que traziam à tona a insatisfação quase generalizada em meio à classe artística. Por isso, a sua importância é ímpar.

Nesse sentido, o teatro brasileiro do pós-64 é claramente de resistência, mais crítico da ditadura direitista e engajado nessa luta em específico. Contudo, o engajamento teatral ocorrido anteriormente ao golpe civil-militar de 1964 (talvez, mais verdadeiramente engajado) 
possuía um traço marcante de resistência política não menor que o do seu sucessor, ao propor, entre outras emendas, uma sociedade sem classes, mudanças político-econômicas, revolução popular e críticas ao capitalismo, tal como Bertold Brecht havia feito. Por aqui, o CPC e o próprio Teatro de Arena conceberam esse germe, o qual, pouco depois do estabelecimento do autoritarismo, focalizou em fazer objeção ao regime que impedia a ascensão da esquerda. Consequentemente, houve uma forte oposição à ditadura civil-militar a partir do sonho de uma geração esquerdista, a essa altura desmantelada. O contexto, principalmente no final dessa década, já na época de ouro do Teatro Oficina, era de guerras e contrastes, como capitalismo versus comunismo, influenciando toda a arte de contestação.

Além disso, para um teatro que demonstra querer o engajamento, é importante não entrar no sistema puramente comercial, mantendo a sua coerência crítica ao realizar análises sociais - a questão ganhou relevância durante o andamento da década de 1960. Então, qualidade e apelo popular sugeririam o equilíbrio perfeito para se atingir um público considerável (os festivais são uma alternativa disso), uma vez que o engajamento acontece também, e sobretudo, na plateia, devendo esta ser popular, embora se possa ter leituras díspares de uma obra, feitas por sujeitos de classes distintas - o texto se concretiza na recepção, dependendo do leitor/espectador. O grande problema do teatro de esquerda, ainda hoje, é que apenas as pessoas de esquerda vão assistir a peças. Em compensação, para fins de convencimento e opinião, seria necessário ter a consciência de Eric Bentley (1969), de "se mostrar" a quem não concorda e/ou a quem se está "atacando", , ação que o Oficina por vezes pareceu realizar (concernente à classe média burguesa), diferente do Arena, que se expôs, apesar das tentativas, mais na sua zona de conforto e em comunhão com o seu fiel público estudantil. Dentro disso, a questão da forma é imprescindível de ser pensada.

Por esse viés, Theodor Adorno (1973) problematiza a relação forma-conteúdo, pois lhe incomoda a colocação do conteúdo acima da forma de uma obra. Realmente, não se costuma creditar um teatro carente de forma arquitetada, ou que se proponha, primeiramente e acima de tudo, falar contra ou a favor de algo. Este é o dilema do autor engajado: ele precisa facilitar e refletir sobre a face formal da sua produção; porém, se focar a sua arte somente nisso, vai se tornar formalista; ao contrário, se for conteudista, não atingirá quem deveria com a sua

\footnotetext{
${ }^{3}$ Fora o mérito, ligado ao engajamento, dado por Bentley (1969) ao fato de o teatro ser realizado em um palco, ele atesta que esse gênero não é apenas dramaturgia engajada, mas uma representação de reação imediata em seus destinatários, em quem impactos são provocados. Como Sartre, o teórico ata o engajamento à política; por conseguinte, a circunstância crítica de um trabalho cênico ser feito contra alguma coisa ou alguém notório é destacável. Ainda, Bentley diferencia a Arte pela Arte (Esteticismo) e o Engajamento, estendendo o último conceito, pois até mesmo o silêncio poderia ser político, no que tange às escolhas estéticas; no entanto, ele se pergunta se estaria chamando a todos os escritores de engajados (o que devemos atentar para não fazer) e filtra isso mediante a politização do artista, presente na obra.
} 
mensagem. Por exemplo, a forma do teatro de Brecht, elogiado por alguns pesquisadores, foi positivamente deliberada pela esquerda, que viu nela um caminho para o teatro engajado de atributos artísticos - indício não substancialmente presente em todo o teatro político, já que as boas intenções sociais podem esbarrar nas especificidades da recepção e na parte formal ineficaz, ocorridas quando a mensagem não chega, quando não se tem o domínio dos códigos ou quando não se adequa a ideia ao público.

Logo, literatura só é literatura pela forma, não pelo conteúdo. Com base nessa afirmação, se uma obra concilia bem a forma, que tem valor em si, com um conteúdo social, ela cumpre uma função, sem perder de vista a sua força estética. Alguns escritores alcançaram essa conjunção de beleza e crítica; outros, quando partiram do princípio do conteúdo, como os cepecistas, não demonstraram grande qualidade formal, no máximo, para efeito de praça pública. Já Brecht, geralmente (não totalmente, porque há peças didáticas, não feitas para serem encenadas, entre as suas criações) equilibrou forma e conteúdo, embora estivesse distante do que prefere Adorno (1973) - de acordo com ele, peças que pesam pelo conteúdo e que não têm beleza estética não resistem ao tempo. Surpreendentemente considerando Beckett engajado, o teórico trabalhava com a ideia da recepção; portanto, é primordial perceber em qual contexto ele enxerga este autor como engajado: a desesperança presente no texto dramático depende do público para ter esse sentido de engajamento; ou seja, Adorno quis dar um exemplo radical de como qualificar um texto aparentemente apolítico enquanto texto político, porquanto isso descende sempre da época e da representação da obra (como é encenada, lida e recebida).

Ao debater literatura engajada e literatura autônoma (não extremamente opostas, em decorrência dos envolvimentos com a realidade empírica), Adorno (1973) critica a dramaturgia de Sartre - segundo ele, simples teoremas de sua filosofia existencialista que enviam conceitos para fora da forma - e a sua teoria, pela ênfase dada aos temas e à política, pois essa remissão ao exterior não seria artística, uma vez que o conteúdo da literatura não é central e se deveria ver a lei formal na dialética dos movimentos interno e externo à obra. $\mathrm{O}$ engajamento adorniano é, por princípio, fundamentado sobre a forma: um escrito desenvolvido em linguagem autocrítica e didática, não visando a significados fora dele e no qual importa a vivência experienciada por personagens e leitores, seria literatura engajada com forma livre e autônoma. Tal engajamento se dá na resistência da linguagem e de seu sentido pelo movimento de atuação, tocando o outro pela experiência de ler (isso também remete à realidade do leitor), não pelos significados prontos. Desse modo, Adorno (1973) vai na contramão de Sartre, porque a temática política poderia prejudicar o engajamento 
adorniano: o escritor e suas intenções são irrelevantes para se pensar a literatura, implicando a forma como a obra se desdobra e significa com os seus elementos internos, estando ela engajada formalmente, em razão de o conteúdo variar socialmente.

Assim sendo, quando o Arena apresentou Tartufo, no começo da ditadura, todo mundo via ali um texto engajado; depois, em direção ascendente, a companhia concebeu Arena Conta Zumbi para levantar o povo contra o regime e manter um nível de mobilização pela semelhança de situações históricas. Diante disso, é interessante visitar a fortuna crítica do espetáculo, tendo ele sido bastante julgado pela crítica de esquerda (que não viu o trabalho com bons olhos), pelo fato de supostamente pecar pela forma, mesmo contendo pesquisa significativa - há a simplificação de personagens e a prática de um maniqueísmo provavelmente exagerado, reduzindo o conflito e dando margem a condenações, como mostraremos. Por outro lado, a plateia o reverenciou; então, com isso, defendendo a peça ao falar da estética popular ambicionada, Boal provavelmente acertou quando privilegiou o seu espectador (já e também politizado). Imediatamente, em Arena Conta Tiradentes, o diretor quis sofisticar a pesquisa formal, entrando a fundo no Sistema Coringa, método que não recebeu a adesão de críticos para quem Brecht e Stanislavski não combinam.

Por conseguinte, a ideia de engajamento artístico adotada aqui se atrela, naturalmente, à política, pensada em termos de tomada de posição; assim, entendemos como engajada a arte largamente vinculada às preocupações político-sociais do período em que se dá - no caso deste estudo, há um teatro que age em consonância com os propósitos da esquerda (a oposição) relativamente à ditadura civil-militar e ao imperialismo capitalista, reagindo contra o regime, desoprimindo a população, denunciando os abusos, entre outras coisas. Dessa maneira, a arte deve ser engajada como um instrumento de afirmação do humanismo, o que só acontece a partir da evidência dada à vida do povo; nisso, a literatura dramática e o teatro devem contribuir com mudanças na mentalidade coletiva e na estrutura social, atentando para a autonomia necessária e para a forma trabalhada de como se chegar até a sua meta.

Finalmente, é pertinente questionar onde situaremos o engajamento. Primeiro, há os tópicos da preconização da liberdade (Sartre), da política expressamente exibida em cena (Bentley) e da preocupação formal (Adorno). Pretendendo conjugar o que faz mais sentido das teorias antevistas, sabemos ter no engajamento uma concepção muito historicizada, própria da segunda metade do século XX e mais de esquerda, como já foi dito - embora se possa ultrapassar a historicidade para considerá-lo uma questão de predisposição do sujeito (como está sugerido em Sartre), em uma perspectiva sem tempo definido, havendo empenho. O desafio, portanto, é tornar o engajamento operacional nos capítulos a seguir, adequando-o 
para os espetáculos e as situações descritas: como visitar as peças levando em conta essas facetas do conceito com o qual se trabalha? Onde as peças mostram serem exemplos de teatro engajado e em relação a quê? Reiterando: antes do golpe de 1964, o engajamento era claro nos espetáculos críticos ao mundo capitalista, mas, depois, não se criticou mais exatamente isso e sim a ditadura como um todo. O engajamento, então, é o elemento demonstrativo de que o golpe civil-militar acirrou as contradições do capitalismo (concentração de renda, desigualdade social, entre demais fatores), não expressando somente uma contrariedade ao governo ditatorial como resultado. Logo, através de paralelismos, apreciaremos duas peças teatrais engajadas (a seus modos) que tencionavam fazer sólidas críticas às estruturas política, econômica e social brasileiras - seja indo ao passado colonial a fim de falar do presente, aproveitando-se até de discursos opressores para atualizar a montagem; seja fazendo referência a um outro sistema aniquilador, o cultural. 


\section{O ZUMBI EM ARENA}

\subsection{Os passos dados até Palmares}

Seguindo os rumos da pesquisa, neste capítulo, pretende-se explorar o mundo de Arena Conta Zumbi, texto dramático escrito por Augusto Boal e Gianfrancesco Guarnieri, em 1965, e montado no mesmo ano pelo Teatro de Arena. A partir dessa peça, objetiva-se enfatizar o engajamento do grupo, atentando para o contexto de sua concepção, já na última fase, propriamente dita, do Arena e três anos antes da estreia do espetáculo que analisaremos em seguida, Roda Viva. Sendo assim, o percurso a ser feito - através de uma leitura própria e detida do texto de Arena Conta Zumbi e considerações sobre o espetáculo, além de contribuições teórico-críticas de estudos anteriores, algumas críticas especializadas imediatas, artigos e entrevistas dos próprios agentes envolvidos, a serem comentados nesta seção - será conduzido no sentido de mostrar as inferências analógicas propostas pela peça: uma guerra de quase cem anos e muito anterior a 1965 que traz à tona o que estava acontecendo no momento de concepção da obra, logo após o golpe civil-militar, mas ainda antes de a história ditatorial ficar mais repressiva com o AI-5.

Como é sabido, durante quase duas décadas, o Arena foi um participante de relevo em nossa vanguarda teatral e artística (porque se abria para outras atividades culturais), promovendo a crítica e a resistência ao regime militar, mas também sendo alvo dele - seja em função de seus trabalhos coletivos, seja por seus fins políticos em teatro, ou ainda por pensamentos, também formais, de seus artistas de esquerda, em uma época fragmentada. Tendo isso em vista, primeiramente julga-se indispensável esclarecer que o Teatro de Arena passou por algumas fases em seu trabalho, estabelecidas de acordo com técnicas e ideias postas em prática, sendo possível afirmar, hoje em dia, que cada uma dessas etapas liga-se à formação progressiva de um caráter politicamente engajado (com níveis de diferença entre si). Boal (2013, p. 166) classifica o Arena, que, sem cultivar um só estilo, como os clássicos Centro Popular de Cultura (CPC) ou Teatro Brasileiro de Comédia (TBC) "dos áureos tempos", é tido como revolucionário (título cuja adequação questionamos parcialmente, no entanto, acertado para introduzir-nos às fases da companhia, visto ter sido dado em função dessa existência): “O seu desenvolvimento é feito por etapas que não se cristalizam nunca e que se sucedem no tempo, coordenada e necessariamente. A coordenação é artística e a necessidade, social.” (BOAL, 2013, p. 166). A reconstrução histórica da companhia já fora realizada por alguns estudiosos teatrais, mas alguns de seus pontos são notáveis e podem 
contribuir com as nossas afirmações futuras. Sábato Magaldi (1984, p. 7-8) resume o significado do Arena no teatro brasileiro, sublinhando a sua força influenciadora:

O Teatro de Arena de São Paulo evoca, de imediato, o abrasileiramento do nosso palco, pela imposição do autor nacional. Os Comediantes e o Teatro Brasileiro de Comédia, responsáveis pela renovação estética dos procedimentos cênicos, na década de quarenta, pautaram-se basicamente por modelos europeus. Depois de adotar, durante as primeiras temporadas, política semelhante à do TBC, o Arena definiu a sua especificidade, em 1958, a partir do lançamento de Eles Não Usam Black-Tie, de Gianfrancesco Guarnieri. A sede do Arena tornou-se, então, a casa do autor brasileiro.

O êxito da tomada de posição transformou o Arena em reduto inovador, que aos poucos tirou do TBC, e das empresas que lhe herdaram os princípios, a hegemonia da atividade dramática. De uma espécie de TBC pobre, ou econômico, o grupo evoluiu, para converter-se em porta-voz das aspirações vanguardistas de fins dos anos cinquenta. A tendência expressa pelo Arena tornou-se vitoriosa, marcando a linha seguida pelo Grupo Opinião, no Rio de Janeiro, e influindo no repertório escolhido pelo TBC, desde 1960.

Em sua formação, em 1953, como a primeira companhia de teatro de arena profissional do Brasil, posta em prática por José Renato, juntamente com Geraldo Matheus, Sérgio Sampaio e Emílio Fontana, saídos da Escola de Arte Dramática (EAD) e já com pesquisas e exercícios iniciais sobre esta forma teatral ${ }^{4}$, que fomentaram a fundação do grupo, o Arena não foi primeiramente pensado para ser um núcleo artístico político ou nacionalizador, mas sim um lugar cênico alternativo ao luxuoso e elitista TBC - a quem se contrapunha, mas do qual originalmente também herdou elementos, como o repertório eclético, apesar do barateamento das produções. Assim, contando com um espaço simples para a ação cênica, como explica Magaldi (1984, p. 8), essa "dessacralização do tradicional teatro" e a oportunidade de termos a arena como forma fizeram com que também se apresentassem espetáculos em outros tipos de sala e que possíveis teatros aumentassem em quantidade. Após percorrer clubes, sindicatos, escolas, etc., deu-se a aquisição da sede própria do Arena, em fevereiro de 1955, que abriu as portas com A Rosa dos Ventos, de Claude Spaak. Ainda, depois de uma exibição para o presidente Café Filho, no Palácio do Catete, instaurou-se o Teatro de Arena do Hotel Glória do Rio, que não resistiu por muito tempo, mas que auxiliou na expansão do Arena, conforme enfatiza Magaldi (1984, p. 15).

\footnotetext{
${ }^{4}$ Magaldi (1984, p. 10-11) diz que a semente do Teatro de Arena foi plantada na EAD, "um laboratório experimental" criado por Alfredo Mesquita, em 1948, escola pioneira ao montar textos mundialmente consagrados por aqui, recente celeiro de onde saíam atores profissionais (algo novo para a época), muitos dos quais iam para o TBC, e um lugar onde nasciam pesquisas em arte, o que também veio a questionar este teatro; lá, José Renato deu vida à primeira montagem em arena feita no Brasil, dirigindo um texto de Tennessee Williams, O Demorado Adeus, orientado por Décio de Almeida Prado e inspirado pelos "fundamentos teóricos do teatro de arena, que dispensa o aparato das salas especializadas", lido nos estudos da americana Margo Jones. Tendo em vista o bom resultado, a estreia da companhia como tal se deu em abril de 1953, com a encenação de Esta Noite É Nossa, de Stafford Dickens, no antigo Museu de Arte Moderna.
} 
Logo, em 1956, o elenco do Teatro Paulista do Estudante (TPE) juntou-se ao do Arena, que escasseava, para que se tivesse um conjunto "estável" e outro "volante", trazendo ao grupo as contribuições de Oduvaldo Vianna Filho e Gianfrancesco Guarnieri - atores envolvidos com a veia e a vida política e estudantil desde cedo, que estrearam na companhia em Escola de Maridos, de Molière. Além disso, um novo diretor, Augusto Boal, assumiu um posto por indicação do crítico Sábato Magaldi para partilhar trabalhos e compromissos com José Renato, o iniciador do econômico teatro, que estava trabalhando em televisão - ademais, José Marques da Costa já havia cooperado na direção. Recém-chegado da Universidade de Columbia, Boal estudara dramaturgia e encenação com grandes nomes (como John Gassner), embora não possuísse muita experiência cênica, contando principalmente com os seus estudos sobre Constantin Stanislavski. A respeito da primeira peça dirigida por este no grupo, Ratos $e$ Homens, de Steinbeck, que obteve sucesso e foi encenada pelos atores do TPE, em outubro do mesmo ano, Magaldi (1984, p. 20-21) ressalta a parceria:

\begin{abstract}
Ratos e Homens assenta em definitivo, também, a colaboração entre os remanescentes do primitivo elenco do Arena e o do Teatro Paulista do Estudante, que já vinha, com a Federação Paulista de Teatro Amador, organizando cursos e difundindo a idéia de formação de grupos teatrais em colégios, por exemplo. A presença de Gianfrancesco Guarnieri e de Oduvaldo Vianna Filho, do Teatro Paulista do Estudante, representava para o Arena "esta juventude que chegava ao teatro, marcada pelas lutas nacionalistas, pela radicalização ideológica, pela percepção da política como atividade que todos praticavam, conscientes (ou não). E era isto que deveriam trazer para o teatro", conforme declarou o próprio Vianninha [...].
\end{abstract}

O Arena se reconfigurou sob a nova liderança: a definidora combinação do diretor carioca com os jovens politizados do TPE, congregando ideias parecidas sobre teatro, ajudou a moldar progressivamente o futuro artisticamente engajado do Arena, pelo qual este ficou conhecido. Boal (2013, p. 166-167) refere-se à época do início da junção - "Em 1956, o Arena iniciou sua fase 'realista'." -, negando o teatro que se fazia em São Paulo, basicamente o do tipo TBC: com muito dinheiro investido, o TBC proporcionou a junção da elite com a classe média em seu público, o que logo se demonstrou inconciliável ${ }^{5}$; já o Arena queria ser um teatro mais próximo da plateia que tinha, sem as ditas estrelas e com personagens abrasileirados:

\footnotetext{
${ }^{5}$ Em Tentativa de análise do desenvolvimento do teatro brasileiro, artigo de 1959, Boal (1981, p. 8-10) ensaia a descrição da evolução do nosso teatro moderno a partir da São Paulo dos anos 40, de acordo com seus três "saltos qualitativos" e "variações quantitativas" até aquele momento ("O teatro alienado", "O teatro simplesmente brasileiro", no qual estaria o seu grupo, e "O teatro popular"), e, localizando o Teatro de Arena dentro disso, de certa forma, o texto vai em direção ao seu engajamento.
} 
A primeira etapa do Arena veio responder às necessidades desta ruptura, e veio satisfazer a classe média. Esta fartou-se das encenações abstratas e belas e, à impecável dicção britânica, preferiu que os atores, sendo gagos, fossem gagos; sendo brasileiros, falassem português, misturando tu e você.

O Arena devia responder com peças nacionais e interpretações brasileiras. Porém, peças não havia. Os poucos autores nacionais de então preocupavam-se especialmente com mitos gregos. [...] Estávamos interessados em combater o italianismo do TBC, mas não ao preço de nos helenizarmos. Portanto, só nos restava utilizar textos modernos realistas, ainda que de autores estrangeiros.

O realismo tinha, entre outras vantagens, a de ser mais fácil de realizar. Se antes usava-se como padrão de excelência a imitação quase perfeita de Gielgud, passávamos a usar a imitação da realidade visível e próxima. A interpretação seria tão melhor na medida em que os atores fossem eles mesmos e não atores. (BOAL, 2013, p. 167)

Igualmente, nesta etapa, após a primeira peça e os contatos iniciais com Stanislavski, Boal, pensando em uma forma mais naturalista de representação, promoveu o Laboratório de Interpretação, no qual, recebendo também atores de fora, se buscava uma interpretação mais brasileira, a partir do realismo praticado pelo método Stanislavski, que fazia vir do ator o sentimento do personagem (algo inspirado no trabalho do Actor's Studio, conhecido por Boal, ao perseguir um "estilo norte-americano"). Conforme aponta Boal (2013, p. 167), no Laboratório explorou-se muito Stanislavski:

O palco tradicional e a forma em arena divergem em suas adequações. Podia-se pensar, inclusive, que fosse o palco a forma mais indicada para o teatro naturalista, já que a arena revela sempre o caráter "teatral" de qualquer espetáculo: plateia diante de plateia, com atores no meio, e todos os mecanismos de teatro sem véus e visíveis: refletores, entradas e saídas, rudimentos de cenários. Surpreendentemente, a arena mostrou ser a melhor forma para o teatro-realidade, pois permite usar a técnica de close-up [...].

[...] Quanto à interpretação, o ator reunia em si a carência do fenômeno teatral, era o demiurgo do teatro - nada sem ele se fazia e tudo a ele se resumia. (BOAL, 2013, p. 168)

O diretor russo sempre foi uma inspiração para Boal, conforme o próprio dizia, e, ao investigá-lo, adveio ao grupo um estilo distinto ao do TBC, inclusive no modo de falar: "Espetáculo brasileiro significava sermos nós mesmos. Não fazíamos considerações de classe, sistema social etc. Apenas isso: memória emotiva. [...] Nós éramos mais parecidos aos nossos espectadores.” (BOAL, 2000, p. 142).

Diante do grupo reformulado e unido, a preocupação com um teatro político, de questionamento da realidade brasileira ganhou importância, mas o primeiro resultado disso surgiu apenas em 1958: os textos encenados ainda não eram nacionais por excelência; todavia, frente ao possível e próximo fechamento do teatro (após excursões fora da cidade, ocupação do espaço por outros grupos e expressões e dispensas de atores), José Renato resolveu 
promover um último e digno espetáculo, demandando um texto de Guarnieri para tal empreitada - era o começo de tudo, não o fim do fazer regular tão desejado, com Eles Não Usam Black-Tie, que obteve enorme sucesso, estimulou o orçamento e deu esperanças de futuro ao grupo, afirmado por meio deste espetáculo, em que se começava a abordar o país criticamente, despertando empatia. Na contramão, como Boal mostra em sua biografia, também houve críticas, julgando que os atores viviam a história, não a interpretavam - isso quanto a este e a outros trabalhos. Sem entrar em pormenores, cumpre dizer que esta peça se ligou ao momento do "nacional-popular" nas artes e colocou a perspectiva do povo brasileiro, através dos operários, no centro da cena e do enredo. Outras rupturas viriam, pois a noção de povo ainda era, de certa forma, genérica, e falava-se de maneira distanciada com e sobre essas pessoas. No entanto, o êxito da realização relaciona-se à origem do Seminário de Dramaturgia de São Paulo: em 1957, deu-se o curso de Dramaturgia, mais informalmente e aberto, que veio a se organizar em 1958, após Black-Tie, virando o Seminário de Dramaturgia, prática conduzida por Boal (com a presença de outros ministrantes eventuais) para o grupo e alguns artistas convidados a se profissionalizar. A missão, preocupada em valorizar as temáticas nacionais e explorar artifícios de dramaturgia, revelou novos e significativos autores para o nosso teatro e reforçou o encanto em torno da consolidação do dramaturgo nacional - algo a que outras companhias também visaram, tendo este caminho sido aberto; assim, basicamente todos os dramaturgos jovens que iniciaram os seus trabalhos na etapa seguinte foram tocados pelos debates oriundos do Seminário, deveras politizados. Ainda quanto ao projeto desenvolvido durante 1958 e 1959, Boal (2013, p. 168-169) fala da urgência de "uma dramaturgia que criasse personagens brasileiros para os nossos atores", o que foi feito debaixo de certo ceticismo e a partir do sucesso de Eles Não Usam Black-Tie 6 . Depois disso, Boal passou a ministrar Dramaturgia na EAD.

Prado (2009, p. 61-62) enfatiza o então novo teatro brasileiro de autores nacionalistas e militantes, politização que ele afirma ter ocorrido num período de amadurecimento do gênero, na passagem entre as décadas de 1950 e 1960, o que corrobora o engajamento político teatral em uma época de se repensar o formal e o social; a seu ver, o Arena estaria antenado aos "imperativos da década" e seria, por aqui, o responsável pela nacionalização do teatro:

\footnotetext{
${ }^{6}$ Também, é importante dar relevo aos debates sobre o teatro brasileiro que se intensificavam, mais programaticamente desde a peça de Guarnieri, no campo da crítica teatral e nas próprias reflexões dos artistas envolvidos com a criação cênica do tempo. O pano de fundo dessas trocas era a situação política interna e externa: a guerra fria, o acirramento da oposição direita versus esquerda, a política desenvolvimentista de Juscelino, o nacionalismo crítico (do ISEB), a consciência do subdesenvolvimento, o anti-imperialismo, a luta de classes, entre outras ocorrências já levantadas no capítulo anterior.
} 
O elenco de Franco Zampari [o TBC] havia influenciado mais pelo exemplo, pela prática, ao contrário do Teatro de Arena, que não só teorizou com abundância, através de notas de programa, entrevistas, prefácios de livro, como procurou sempre reescrever em benefício próprio a história recente.

[...] Não foi, todavia, a forma "teatro de arena", embora ela obrigasse a uma reformulação completa das relações quer entre os atores em cena, quer entre estes e o público, que deu prestígio ao conjunto. (PRADO, 2009, p. 62-63, inclusão e grifos nossos)

O auge só se deu com o acréscimo dos três jovens artistas já mencionados, que se influenciaram mutuamente e deram cara ao Arena: Boal, que vinha dos EUA com o playwriting (técnica textual) e o método Stanislavski (técnica de interpretação, de "veracidade psicológica") na bagagem; e Vianna Filho e Guarnieri, membros de linhagens de artistas de esquerda, de movimentos estudantis e do TPE, que defendiam a presença da "realidade política nacional” na arte teatral (PRADO, 2009, p. 63).

\begin{abstract}
A grande originalidade, em relação ao $\mathrm{TBC}$ e tudo o que este representava, era não privilegiar o estético, não o ignorando mas também não o dissociando do panorama social em que o teatro deve se integrar. Desta postura inicial, deste "engajamento" palavra lançada pouco antes por Sartre - é que adviriam os traços determinantes do grupo, o esquerdismo, nacionalismo e o populismo (em algumas de suas acepções), a tal ponto entrelaçados que apenas a abstração conseguirá separá-los. (PRADO, 2009, p. 63)
\end{abstract}

Portanto, a etapa que se inaugura com os textos, em sua maioria, saídos do Seminário, foi chamada de "fotografia" e seguiu a tendência da fase anterior quanto à interpretação realista, mas pretendeu, sobretudo, falar dos problemas do Brasil por meio de textos brasileiros. Dela, Boal (2013, p. 169) destaca:

Em fevereiro de 1958, começou. Eles não usam black-tie, de Gianfrancesco Guarnieri, foi a primeira, e ficou todo o ano em cartaz até 1959. Pela primeira vez, em nosso teatro, o drama urbano e proletário.

Durante quatro anos (até 1962), muitos estreantes foram lançados [...].

Foi um longo período em que o Arena fechou suas portas à dramaturgia estrangeira, independentemente de sua excelência, abrindo-as a quem quisesse falar do Brasil às plateias brasileiras.

Esta etapa coincidiu com o nacionalismo político, com o florescimento do parque industrial de São Paulo, com a criação de Brasília, com a euforia da valorização de tudo nacional.

As peças tratavam do que fosse brasileiro: suborno no futebol interiorano, greve contra os capitalistas, adultério em Bagé, vida sub-humana dos empregados em ferrovias, cangaço no Nordeste e a consequente aparição de Virgens e Diabos etc.

O estilo pouco variava e pouco fugia do fotográfico, seguindo demasiado de perto as pegadas do primeiro êxito da série. Eram as singularidades da vida o principal tema desse ciclo dramatúrgico. E esta foi a sua principal limitação: a plateia via o que já conhecia. Ver o vizinho no palco, ver o homem da rua ofereceu de início grande prazer. Depois, todos perceberam que podiam vê-los fora do palco sem pagar entrada.

A interpretação, nesta fase, continuou o caminho já trilhado antes, continuou 
Stanislavski. Porém, antes, a ênfase interpretativa era dada a "sentir emoções"; agora, as emoções foram dialetizadas e a ênfase passou a ser posta no "fluir de emoções".

Além da sistematização do método de interpretação, dessa fase, Boal (2013, p. 170) ressalta o ingresso de Flávio Império no grupo, dando as primeiras contribuições cenográficas ao Arena; no entanto, encaminhava-se o fim do ciclo: foram muitos os seus ganhos (a dramaturgia nacional aumentou em número e conquistas, inspirada pelo Arena, além de começar a praticar "um teatro mais brasileiro e menos mimético"); entretanto, houve a inconveniência da repetição das obviedades: “Queríamos um teatro mais 'universal' que, sem deixar de ser brasileiro, não se reduzisse às aparências. O novo caminho começou em 1963." (BOAL, 2013, p. 170).

Nesse tempo, início dos anos 60, com obras e finanças sendo limitadas por seu pequeno espaço, mais viagens se fizeram necessárias, sabendo-se que o público desejado, o povo do campo (o "povo autêntico", conforme Boal reiterava), estaria no Nordeste, para onde o Arena foi em determinado momento. Ao mesmo passo, a preocupação social aumentou dentro da companhia e a busca pelo povo (em se fazer uma arte com e para este público) foi algo importante a ser pensado, incluindo-se nisso os equívocos desta aproximação, como a ausência desta gente dentre a plateia frequente (onde predominava a classe média), o emprego de diálogo a qualquer custo, por parte do grupo, e a conscientização popular autoritária.

Ainda com relação a esses fatos e a essas buscas esporádicas, é importante ressaltar a cisão ocorrida no início da década de 1960. O Arena foi apresentar o seu repertório no Rio de Janeiro e, diante disso, Vianinha e Chico de Assis resolveram permanecer na cidade, pois já não estavam totalmente de acordo com a linha profissionalizante e "afastadora" do povo com a qual se conduzia o Teatro de Arena: “A insatisfação floresceu também no Arena, e se começou a pensar em formas alternativas de teatro, o que implicaria, necessariamente, em abandonar a estrutura profissional, voltar ao amadorismo. Guarnieri e eu queríamos continuar profissionais." (BOAL, 2000, p. 178). Nesse tempo, José Renato, também tencionando popularizar-se, foi estagiar no Théâtre National Populaire (TNP) e o grupo se fragmentou: no Rio, alguns componentes envolviam-se com membros do Partido Comunista (PC) e iniciavam um novo grupo, e, em São Paulo, a Revolução na América do Sul era encenada. O próprio Vianna Filho, que se relacionou mais diretamente com segmentos do PC e foi um dos fundadores do CPC da UNE, já se referiu ao tema da separação, visto que, permanecendo a amizade, suas concepções de arte política (engajada e popular) diferiam das ideias do grupo paulista. É interessante visitarmos uma entrevista de Guarnieri, concedida a Fernando Peixoto, em que ele fala sobre o CPC com um olhar "de fora", uma vez que este era originalmente um 
projeto do TPE, não do Arena:

O Arena já realizava seu trabalho em outras bases, ainda que tudo estivesse muito próximo, muito interligado. [...] Agora, no Arena, em relação ao problema do CPC, o que discutíamos muito era o seguinte: éramos contra um tipo de dramaturgia panfletária, que era chamada de popular, mas para nós não era popular, era só panfleto mesmo, despido de qualquer atrativo, de qualquer consequência efetiva em termos de teatro. Um trabalho que achávamos eminentemente político, mas que só teria validade na medida em que o confronto de forças já estivesse num ponto que permitisse esse tipo de luta artística, transformando a utilização da fórmula dramática. Reduzindo-a a uma espécie de teatro de trincheira. Aí poderia ser válido. Agora, nas condições existentes, achávamos que não era aquele o caminho. O que se deveria procurar não era a dramaturgia imposta de cima para baixo, como eles faziam, paternalista. E antidemocrática mesmo, achávamos também. No Rio, eles pensavam o contrário. Isso gerou uma série de polêmicas interessantes. Mas de nível. Quer dizer, ninguém queria ficar se agredindo, eram discordâncias de posição. O que a gente buscava era se entender. Enfim, o problema era, no fundo, de nível mesmo: pode chegar um determinado instante em que seja necessário aquele tipo de trabalho. Mas no geral, ou no caso específico daquele momento, a gente não concordava. No geral, você não pode jamais esquecer que, fundamentalmente, qualquer forma de expressão artística exige uma dedicação a ela, um cuidado com ela. Com a própria forma de expressão, sim, porque é aí que ela adquire força para atingir. Senão, não atinge nada. Ela passa a confundir. E acho que precisávamos de um conhecimento bem mais profundo da própria realidade, de um levantamento mais explícito e claro. Precisávamos de um trabalho de aprofundamento mais coordenado. (GUARNIERI, 1985 , p. 55)

Não se pretende adentrar a fértil e breve história do CPC durante esta dissertação, o que já foi executado por autores como Fernando Peixoto e Edélcio Mostaço, por exemplo. Contudo, abriremos espaço, no presente texto, para confrontar argumentações de alguns artistas e intelectuais comprometidos nesse processo - tanto da separação do Arena e do surgimento do CPC, quanto da questão da busca pelo povo ou pelo caráter popular da arte -, que expuseram suas atitudes frente ao caráter engajado (possivelmente) atribuído ao Arena, exibido na vinculação ao público, na concepção das peças e no posicionamento contra o regime militar.

Do Arena ao CPC, de Vianinha, texto publicado em 1962, versa intrinsecamente a respeito da sua saída de um grupo para a formação do outro, o que teria a ver com a problemática empresarial do Teatro de Arena. No entanto, através disso, vemos um exame pessoal sobre o momento do próprio teatro no país, assim como sobre o componente artístico popular e os motivos da criação do CPC, unido culturalmente à política. Primeiramente, Vianna Filho (1983, p. 90-91) diferencia a média empresa (ainda sem "uma política cultural") da grande empresa, afirmando que o Arena não se encaixa em nenhuma das alternativas, porque, deslanchando como "o simpático teatrinho", melhor lidou com as condições econômicas e sociais e teve como base uma plateia politizada, identificada com a situação: 
"Um público que via muito mais Brasil nos esforços culturais de conscientização do que nas realizações externas e desvinculadas". (VIANNA FILHO, 1983, p. 91) Com isso, Vianna Filho (1983, p. 91) diz que a simpatia foi se definindo como atuação (engajada, diríamos) e que esse processo se dava ao passo em que companhias sem autenticidade se vendiam formalmente enquanto o Arena vendia matérias, questionando-se a partir da sua fiel audiência. $\mathrm{Na}$ sequência, ele discorre longamente sobre a cisão do Arena e podemos antever a razão de sua saída, a escassez de massas:

\begin{abstract}
O Teatro de Arena, porém, trazia dentro de sua estrutura um estrangulamento que aparecia na medida mesmo em que cumprisse a sua tarefa. O Arena era porta-voz das massas populares num teatro de cento e cinquenta lugares... O Arena não atingia o público popular e, o que é talvez mais importante, não podia mobilizar um grande número de ativistas para o seu trabalho. A urgência de conscientização, a possibilidade de arregimentação da intelectualidade, dos estudantes, do próprio povo, a quantidade de público existente, estavam em forte descompasso com o Teatro de Arena enquanto empresa. Não que o Arena tenha fechado seu movimento em si mesmo; houve um raio de ação comprido e fecundo que foi atingido com excursões, com conferências etc. Mas a mobilização nunca foi muito alta porque não podia ser muito alta. E um movimento de massas só pode ser feito com eficácia se tem como perspectiva inicial a sua massificação, sua industrialização. É preciso produzir conscientização em massa, em escala industrial. Só assim é possível fazer frente ao poder econômico que produz alienação em massa. O Teatro de Arena, esbarrando aí, não teve capacidade, naquele movimento, de superar esse antagonismo. O Arena contentou-se com a produção de cultura popular, não colocou diante de si a responsabilidade de divulgação e massificação. Isto sem dúvida repercutiria em seu repertório, fazendo surgir um teatro que denuncia os vícios do capitalismo, mas que não denuncia o capitalismo ele mesmo. O Arena, sem contato com as camadas revolucionárias de nossa sociedade, não chegou a armar um teatro de ação, armou um teatro inconformado. Guarnieri, Boal podem ou não escrever peças de ação, mas um movimento de cultura popular não pode depender de talentos pessoais - é preciso que a empresa tenha uma existência objetiva de tal tipo que a obrigue a mobilizar todos os seus elementos na criação de um tipo de teatro. Uma empresa que seja sustentada pelo povo para, objetivamente, ser obrigada a falar e ser entendida por esse povo. Um movimento de cultura popular usa o artista corrente, usa uma ideologia de espetáculo que precisa pertencer à empresa, e não aos seus representantes individuais. Nenhum movimento de cultura pode ser feito com um autor, um ator etc. É preciso massa, multidão. (VIANNA FILHO, 1983, p. 93)
\end{abstract}

Considerando que o papel da arte é possibilitar ponderações da sociedade sobre si, Vianna Filho (1983, p. 94) realiza uma autocrítica relacionada ao teatro popular (controvérsia estética e política): não concordando com as fronteiras do realismo, ele afirma ter ido à procura de "uma nova forma" sem pensar em "um novo conteúdo", alienando-se, ao que adiciona, ainda, "a passividade humana” de suas peças, bem como das realistas. Importando o entendimento, o autor sentencia que os instrumentos de sensibilização suscitados por uma peça precisam constar nela mesma, não em um saber anterior e exterior presumido no público: 
É preciso um teatro ajustado à capacidade intelectual do povo brasileiro. Um teatro com formas já consagradas pela percepção popular. A forma nova será nova historicamente, será nova em relação à situação cultural da sociedade - não será necessariamente nova na história da arte. (VIANNA FILHO, 1983, p. 94)

É viável pensarmos que o CPC não fez exatamente isso (ao focar especialmente no conteúdo das obras), mas a revisão crítica do autor ainda é válida. A partir disso, o final do texto de Vianna Filho (1983, p. 95) enviesa pelo caminho de mostrar o que poderia vir a ser um "teatro político popular" ideal para ele (ultrapassando o teatro de viés social, o qual contrapõe "os critérios morais e as necessidades morais"), mais fabular e menos subjetivo: "Um teatro de criação e não de imitação do real. Um teatro otimista, direto, violento, sátiro e revoltado como precisa ser o povo brasileiro.” (VIANNA FILHO, 1983, p. 95).

Ulteriormente, com o desbaratamento dos CPCs em função do golpe civil-militar de 1964, o artista mostrou posição política mais moderada, embora tenha se mantido à esquerda (com o PCB, no qual era filiado), até mesmo se abrindo ao caráter mercantil da cultura, características notáveis em passagens de Um pouco de pessedismo não faz mal a ninguém, texto de 1968.

Já Guarnieri, durante a referida fase de mudanças, deu a entender o que buscava com relação à arte teatral. No ensaio-manifesto $O$ teatro como expressão da realidade nacional, falando sobre teatro político em 1959, Guarnieri (1981b, p. 6) dá o tom de uma problemática exposta ao profissional de teatro, na época: a falta de dramaturgia própria inviabilizava a criação de um teatro brasileiro, também um anseio do público; no entanto, a juventude envolvida com teatro já investigava formas de versar sobre o país - remetendo-nos a ideias engajadas de Sartre e àquelas explanadas no primeiro capítulo deste trabalho. Nessa perspectiva, há a defesa de uma dramaturgia nacional - mais ainda - da que reflete conteúdos de classe, sendo animador, para este pecebista, diante do seu projeto, o surgimento de novos autores (viabilizado pelo Arena):

A obra dos novos autores brasileiros demonstra claramente a necessidade geral de tratar de temas sociais, problemas de nosso povo em nosso tempo, o que nos dá a medida de quanto nossa juventude se aflige com os problemas atuais e quanto os artistas jovens procuram participar dessas lutas.

Quando nossos autores chegarem ao ponto de amadurecimento que lhes permita uma consciente definição em sua obra, teremos uma dramaturgia que refletirá realmente um conteúdo de classe - seja da classe dominante, seja da classe explorada. Uma tomada de posição é indispensável, pois de nada valem subterfúgios mascarados de "objetivismo", "visão apolítica dos fenômenos", "exigências psicológicas das personagens", etc. para ocultar atitudes reacionárias e contrárias aos mais altos interesses de nossa gente. $\mathrm{O}$ que se exige é que os autores transmitam mensagens com plena consciência delas. Não podemos admitir tergiversações. 


\begin{abstract}
A falta de uma tomada de posição política e ideológica em quem procura exprimir em sua obra artística os problemas de seu tempo e de seu povo resultará numa perplexidade diante de suas lutas. Os caminhos se embaralharão, as soluções aparecerão enevoadas, uma profunda angústia sobrevirá, pois é a marca dos indefinidos em nosso tempo. Uma definição pessoal se impõe [...]. (GUARNIERI, 1981b, p. 6-7)
\end{abstract}

Para o ator e dramaturgo Guarnieri (1981b, p. 7), a escolha pelo "meio termo" seria inviável e a decisão andaria ao lado do que se sugere ser uma posição política de atuação junto ao povo. Nada mais engajado... Logo, defendendo a cultura popular, o autor argumenta a favor de uma dramaturgia de debate dos problemas enfrentados pelo proletariado e, igualmente, que a análise da realidade social, política e econômica deve ser feita com base na análise marxista:

\begin{abstract}
Não vejo outro caminho para uma dramaturgia voltada para os problemas de nossa gente, refletindo uma realidade objetiva do que uma definição clara ao lado do proletariado, das massas exploradas. Para analisarmos com acerto a realidade, para movimentarmos nossos personagens em um ambiente concreto e não de sonho, o único caminho será o aberto pela análise dialético-marxista dos fenômenos, partindo do materialismo filosófico. Não há caminho de conciliação. Não há meios de fugirmos a uma definição político-ideológica se quisermos realmente, como artistas, expressar com exatidão o meio em que vivemos. Portanto, não há possibilidade de uma definição do artista em sua arte sem que antes se defina como homem, como elemento da sociedade, como participante ativo em suas lutas. (GUARNIERI, 1981b, p. 7)
\end{abstract}

Portanto, manifestando o seu pensamento engajado, e em certa medida também o do Arena, ao defender as presenças da realidade e do tempo atual no teatro, a ultrapassagem de uma cultura mais tradicionalista, o contato e a elucidação junto às massas e o auxílio artístico ao desenvolvimento social, o que Guarnieri (1981b, p. 7) expõe é a urgência da ligação do artista e da arte com o povo, sendo este o sonho de "teatro popular" (que demandaria ações estatais) a ser feito às classes mais populares - uma questão política, mas ainda longínqua, havendo antes outras prioridades que o teatro poderia amparar (obstáculos, quando se pensa em levar arte a todos). Por conseguinte, enquanto não atingem as massas, podemos concluir que os espetáculos deveriam ser feitos para a minoria pagante de ingresso e, sempre que possível, poderiam ser realizados para as massas.

Com relação a esse alcance, Prado (2009, p. 98-99) aponta que o "empenho político" do teatro, em dado momento, entrou em descompasso com os limites de tamanho e público (presentes no Arena), insuficientes para uma revolução em larga escala; dessa forma, o contato mais direto com o povo e com a luta popular se fazia necessário para alguns agentes de teatro, que visaram, com a criação do CPC, em 1961, por exemplo, a uma transformação 
social pelo viés artístico: este grupo era, em função de seus fundadores, descendente do Arena, ao qual se opunha, pois, com o teatro coletivo e efêmero, subordinava a arte à política em função da revolução que pretendia promover, sem preocupações profundas com o lado financeiro, somente com a educação do povo por um objetivo maior. Assim, o traço popular cepecista difere-se substancialmente das noções do Arena (centralizadas nos pensamentos de Boal e Guarnieri), principalmente nas questões formal e profissional.

Considerando os sinais de desunião da esquerda de então, no teatro sócio-político:

\begin{abstract}
Os anos imediatamente anteriores e posteriores a 1964 enfatizavam a dramaturgia política, ainda mais que a social. Se não era esse todo, nem talvez o melhor teatro, foi sem dúvida aquele em que a comunidade teatral, representada por suas facções mais combativas, melhor se reconheceu. O país dividia-se e ninguém, autores ou público, críticos ou intérpretes, aceitava ficar à margem dos acontecimentos. A idéia de que a arte é sempre engajada, por ação ou omissão, por dizer sim todas as vezes em que se esquiva a dizer não ao status quo, fornecia o diapasão pelo qual cada um afinava o seu instrumento.

[...] A aliança entre teatro e povo, era o que todos pretendiam cimentar, mas por motivos e sob formas diversas, ora em bases poéticas, ora em bases políticas, ora para o bem do teatro, ora para o bem do povo. [...] Outros enxergavam no palco um veículo precioso a quem desejasse ministrar à "massa trabalhadora" (expressão de Vianinha) as noções de que ela necessitava não só para se defender como para contra-atacar no momento oportuno. (PRADO, 2009. p. 97; 100)
\end{abstract}

Ficam evidentes os receios que acometeram Boal na busca pelo povo. Corroborando isso, Prado (2009, p. 100-101) mostra esse "interlocutor ideal do teatro" e sua inspiração transformadora (não formal), como era geralmente considerado o povo, permanecendo passivo a respeito das mensagens teatrais, que vinham de cima para baixo, autoritariamente, e poderiam não ser recebidas. Então, por mais que não visasse a um contato imperativo, o Arena empreendeu-o com o fim de fazer esse povo chegar à consciência de si mesmo e da sua força. Via compromisso e empolgação, após Black-Tie, o alargamento de público e locais de apresentação se deu na direção dessa recepção popular a ser conquistada (com a ajuda de organizações culturais) ${ }^{7}$.

A contradição populista do Arena, rechaçada pelo CPC (e por ele mesmo, em autocríticas), nos lembra a dos escritores burgueses do século XIX (mencionada por Sartre), os quais, não querendo mais se ligar exclusivamente às classes médias, mas sem deixar o profissionalismo de lado, acabavam sendo sustentados por estas, sendo incompatível a sua ideia de popularização com o ordenado do proletariado destinado à cultura. Para sanar tal

\footnotetext{
${ }^{7}$ A aproximação com as massas, um tópico central para o teatro do período, também foi uma preocupação durante o processo de desenvolvimento do engajamento do Teatro Oficina. Este, por sua vez, também teve suas fases, não tão exaustivamente classificadas quanto as do Arena; entretanto, pode-se dizer que a partir de $O$ Rei $d a$ Vela se iniciou o período mais relevante do grupo, no qual houve aproveitamento de elementos da contracultura. Ademais, nele se localiza a peça a ser lida no próximo capítulo.
} 
entrave, necessita-se de apoio empresarial e/ou estatal, algo escasso em tempos ditatoriais no meio da arte esquerdista, e que, quando houve, limitou as realizações. Outro contrassenso ligado ao povo é o fato de que, embora o teatro de preocupação social com ênfase nas classes trabalhadoras queira se destinar a elas, este não lhes concedeu os chamados "meios de produção", sempre nas mãos das camadas médias - isso fez com que o Arena não unisse, em sua expressão, a burguesia e o povo, para quem se apresentava. Sendo assim, podemos afirmar que a companhia não atingiu a total popularização teatral ambicionada (na época de Zumbi, com um público ideologicamente cúmplice, frente aos perigos, isso foi até mesmo ultrapassado por outras prioridades), não havendo, ligada a si, uma produção de fato feita pelo e para o povo, embora o seu legado tenha sido passado a outros grupos, fomentando o teatro engajado e popular posterior.

Continuando a recuperação da trajetória, é importante mencionar que José Renato, ao ir para o Teatro Nacional de Comédia, em 1962, vendeu o Arena para Boal, Guarnieri (em seu retorno, após a partida com Gimba), Flávio Império, Juca de Oliveira e Paulo José, então sócios. Estando o quinhão da autoria nacional mais estável em nosso teatro, sem ser preciso se afirmar ininterruptamente, a companhia seguiu o seu fluxo inventivo, sendo uma de suas destacáveis características a consciência não acomodada de saber que o fim de uma fase abria espaço para uma proposta inédita. Assim, ainda antes da mudança política brusca, o grupo se propôs a nacionalizar os clássicos ditos universais, de qualquer lugar e tempo, não perdendo de vista o jeito brasileiro ao dramatizar os textos. Como dizia Boal, nenhum clássico seria universal sem antes ser brasileiro: os textos não precisavam ser nacionais para refletirem a brasilidade e a universalidade (defendia-se que a vida do ator fazia parte do espetáculo), através das quais se buscaram feições e tom próprio, nacional (como no Laboratório e no Seminário), indo-se não pelo caminho do naturalismo, mas por ecos em outros lugares e pela metáfora. Nesse período, portanto, começam os trabalhos alusivos do Arena, mais conscientemente, pois, adaptando em maior ou menor grau os textos nacionalizados, visava-se à adequação com determinados fatores sociais da nossa realidade - no geral, a recepção entendia a intenção metafórica naturalmente, presente em todas as peças nacionalizadas, em algum grau. Quanto a essa etapa, Boal (2013, p. 170) comenta que alguns clássicos foram nacionalizados temporalmente na etapa seguinte: “A 'nacionalização' era feita diversamente, dependendo dos objetivos sociais do momento." (BOAL, 2013, p. 170). Como exemplos, temos A Mandrágora, montada para tematizar o poder; Melhor Juiz, o Rei, concebida com modificações significativas para incitar o povo à ideia de justiça popular (praticada por um camponês ao invés de um rei); e Tartufo, feita sem qualquer modificação, porque, ao falar 
sobre a hipocrisia religiosa, o seu enredo traduzia o momento pós-golpe (em que o nome de Deus era constantemente evocado pela direita), mostrando-nos o ludíbrio do qual é capaz a combinação de política e religião. Este último espetáculo, em que o público antevia o seu país, "reabriu" o Arena, em setembro de 1965, após a parada obrigatória da temporada de $O$ Filho do Cão por causa do golpe, do consequente questionamento frente ao momento político e à situação econômica e da nova ocorrência de quase encerramento do teatro. Para que se pudesse radicar no nosso tempo e lugar, tratavam-se esses textos como
se não estivessem radicados à tradição de nenhum teatro de nenhum país. [...]
Pensávamos naqueles a quem nos queríamos dirigir, e pensávamos nas inter-relações
humanas e sociais dos personagens, válidas em outras épocas e na nossa. Claro que
chegávamos sempre a um "estilo" - porém nunca aprioristicamente. Isso nos dava a
responsabilidade de artistas criadores e nos retirava os limites da macaqueação.
[...] Ainda no terreno interpretativo, outra ênfase foi deslocada. Cada vez mais
passou ao primeiro plano a interpretação social. Os atores passaram a construir seus
personagens a partir de suas relações com os demais, e não a partir de uma discutível
essência. Isto é, os personagens passaram a ser criados de fora para dentro.
Percebemos que o personagem é uma redução do ator, e não uma figura que paira
distante e flutua até ser alcançada por um instante de inspiração. (BOAL, 2013, p.
171-172)

Conforme Boal (2013, p. 172), a fase anterior, da fotografia, fechava-se excessivamente "na exaustiva análise de singularidades", e esta, a da nacionalização dos clássicos, amarrava-se "à síntese de universalidades": "Uma apresentava a existência não conceituada; outra, conceitos etéreos. / Era necessário tentar a síntese.” (BOAL, 2013, p. 172).

A etapa dos musicais pretendia ser uma solução sintética e, sobretudo, uma reafirmação política do grupo, porque se localizou exatamente depois do golpe civil-militar não que o grupo já não tivesse se politizado antes desse acontecimento; porém, nesse momento, os seus objetivos ligavam-se profundamente aos desdobramentos do estabelecimento da ditadura (por exemplo, em como fazer alusão e opor-se a isso), que, no início da fase, em Zumbi, era um regime visto como passageiro. Ainda, estava-se sob os influxos do Show Opinião (muito em função de Boal, que o dirigiu, incentivando o investimento nessa veia), no caso, um show, diferentemente de Zumbi, o primeiro espetáculo teatral de resistência mais direta à ditadura, segundo o vemos hoje em dia.

Como é de conhecimento público, o regime militar bloqueou (pouco a pouco e não imediatamente) aquilo que vinha sendo feito em nosso teatro desde o fim dos anos 50 e início dos 60 , de caráter popular. O teatro de viés político contava, principalmente, com o próprio Teatro de Arena, que, a partir de Eles Não Usam Black-Tie, discutiu os malefícios do capital e a estrutura social, e com o CPC, apresentando peças de agitprop de esquerda, debatedoras do 
imperialismo e do capitalismo - não custa lembrar que este grupo, pretendendo fazer um teatro transformador e esclarecedor das massas populares, colocando-se próximo a elas, foi desmantelado com o golpe. Após o estabelecimento do regime, em 1964, o Arena interrompeu suas atividades até vir a montar Tartufo, de Molière, conforme vimos, um texto estrangeiro pertencente à fase de nacionalização dos clássicos. O Teatro Oficina, um aliado da esquerda artística que encenava mais peças estrangeiras, também parou a temporada na qual montava Gorki, naquele momento. A primeira e necessária resposta da arte à ditadura, como é sabido, foi o Show Opinião, do Grupo Opinião (formado a partir de membros do CPC), em que se promovia a catarse política e a visão crítica da realidade. No Rio e em São Paulo, os artistas pensavam em como responder ao novo regime e eis que se deu o "show-verdade", como chamou Boal (2000, p. 224-228) em sua biografia: nele, cantores cantavam as suas histórias, tentando se aproximar do povo, e uma forma surgia - queria-se focar na ideia do que era passado, mais do que na música, porque esta realização inaugurou uma fase de protesto teatral.

Nos documentos deste espetáculo, há uma amostra do que viria nos próximos projetos de Boal, pois, muito envolvido no processo, ele defendia o engajamento. Com suas experiências mais solidificadas, o diretor defendia a presença da realidade na arte, demanda também vinda do público, mesmo que houvesse vacilo na busca de certezas, como expôs Magaldi (1984, p. 66-67), erigindo-se “o espetáculo do homem de teatro brasileiro" como um todo necessário, a partir disso. Nesse momento, ficava clara a existência de um só caminho para o teatro político brasileiro poder florescer: ser uma frente de resistência. Liberdade, liberdade, de Millôr Fernandes e Flávio Rangel, montado pelo Grupo Opinião, seguiu com a crítica. O Arena, em São Paulo, após retomar os trabalhos e passar por um período de indecisões, presenciou a chegada de Opinião à cidade, mas continuou com a nacionalização e começou a pensar em uma nova maneira de se alinhar ao teatro de resistência, prática que aconteceu com Arena Conta Zumbi, estreada em $1^{\circ}$ de maio de 1965, um ano e um mês depois do golpe. Iremos explorar melhor os aspectos dessa obra na seção a seguir, mas, desde já, é importante dizer que, ao narrar a luta de Palmares por liberdade, tema da peça, Zumbi equivaleu o passado colonial da história negra ao confronto com a ditadura do presente, estabelecendo relações com a situação do país na época de escritura do texto bem claras para a sua audiência, composta majoritariamente por estudantes e artistas de esquerda. Inclusive, como se verá, paródias de discursos políticos ganharam espaço dentro da dramaturgia, em que é mostrada a novidade formal do aproveitamento do teatro épico brechtiano, aspecto a ser visitado - a grande ruptura da proposta é o fato de a história ter sido mais narrada do que vista no palco, além da adequação da técnica de desvinculação ator-personagem ao teatro político 
proposto. Fora isso, alguns outros recursos facilitavam a compreensão da mensagem pelo público, característica que rendeu algumas críticas à direção, até mesmo por setores da esquerda (em dúvida entre a satisfação estética e esquemática) - no entanto, há uma mitologia em torno da suposta simplificação formal do Arena, que foi desmentida por críticos e, na medida, incansavelmente defendida por Boal, com o maniqueísmo da peça e a ocorrência da música de protesto, pois ele reforçava que a raiz de um espetáculo assim era popular e que essas saídas estariam de acordo com as suas finalidades de esclarecer o conflito, ou seja, o diretor apostava na eficácia politicamente engajada do trabalho apresentado. De fato, há muita comunicabilidade em Zumbi e o seu consequente sucesso foi considerável, validando a estratégia empregada pela esquerda para "ajudar" didaticamente a plateia burguesa, o seu povo agora, a entender os acontecimentos recentes com mais clareza. Zumbi era um musical enraizado no presente, o qual contestava em tom de luta.

Por outro lado, a censura cresceu durante a ditadura (Opinião e Zumbi tiveram cortes), estando presente em tudo o que se direcionasse a um público, avançando, em 1966 e 1967, rumo aos anos de recrudescimento do AI-5. O momento, contudo, mostrou-nos não somente as preocupações dos autores em relação ao conteúdo de suas peças, mas, também, o desenvolvimento de novas formalizações estéticas para apresentar essas matérias e reflexões políticas da melhor maneira, aproximando ficção e realidade. Ligado a isso, é interessante ver que, porquanto a crítica direta ao plano contextual não era permitida, a volta ao passado alusiva ao presente e as metáforas empregadas (praticadas sobretudo por Guarnieri, nos anos de chumbo) foram impecavelmente utilizadas diante da limitação da liberdade de expressão. Seguindo nessa passagem de tempo dos musicais, Boal (2013, p. 173) dá importância a Zumbi, falando respectivamente sobre forma e conteúdo:

Zumbi propunha-se a muito e o conseguiu bastante. Sua proposta fundamental foi a destruição de todas as convenções teatrais que se vinham constituindo em obstáculos ao desenvolvimento estético do teatro.

Procurava-se mais: contar uma história não da perspectiva cósmica, mas, sim, de uma perspectiva terrena bem localizada no tempo e no espaço: a perspectiva do Teatro de Arena e de seus integrantes. A história não era narrada como se existisse autonomamente: existia apenas referida a quem a contava.

Zumbi era peça de advertência contra todos os males presentes e alguns futuros. E, dado o caráter jornalístico do texto, requeria-se conotações que deveriam ser, e foram, oferecidas pela plateia. Em peças que exigem conotação, o texto é armado de tal forma a estimular respostas prontas nos espectadores. Essa armação e esse caráter determinam a simplificação de toda a estrutura. Moralmente, o texto torna-se maniqueísta [...]. [...] também, no caso de Zumbi, o texto deveria ser amparado pela música, que, nessa peça, tinha como missão principal preparar ludicamente a plateia para receber as razões contadas. 
Ainda sobre o desmantelamento de convenções, Boal (2013, p. 173) menciona a empatia em Zumbi, que deveria ser retomada através de um sistema: "Não podendo identificar-se a nenhum personagem em nenhum momento, a plateia muitas vezes se colocava como observadora fria dos feitos mostrados.” (BOAL, 2013, p. 173). Isso já dá uma dimensão do distanciamento brechtiano residente na peça, a nosso ver, combinável a um certo estágio de identificação.

Retomando a linha progressivamente politizada do Arena até 1967, Boal (2013, p. 173) é crítico quanto ao momento:

Cada uma de suas etapas sempre ligadas ao desenvolvimento social do Brasil. Quando a fase nacionalista do teatro foi sucedida pela nacionalização dos clássicos, o teatro chegou ao povo, indo buscá-lo nas ruas, nas conchas acústicas, nos adros de igrejas, no Nordeste e na periferia de São Paulo.

De popular e gratuita, quando se conseguia subvenções, algo já inviável com a "morte" anunciada do teatro (situação agravada também por crises), a arte pode vir a ser elitizada quem detém o poder não deseja um teatro popular -, o que precisa ser refutado pelos artistas, conforme Boal (2013, p. 173-174), os quais devem sempre buscar-se no povo.

A respeito da época, Magaldi (1984, p. 71-72) destaca a existência de outros musicais feitos pelo Arena (talvez menos importantes), os quais tiraram proveito do sucesso do primeiro ou da fama crescente dos artistas envolvidos, tendo sido 1965 um bom ano para o grupo, que, visando propor a reafirmação de um teatro brasileiro, novamente urgente, e um reacerto de direções, montou outro Seminário diante do novo cenário político, em 1966, entretanto, de duração curta (apesar de este ter dado ensejo a um manifesto). Arena Conta Tiradentes, segundo musical importante, pertencente a esta fase do Teatro de Arena, está na mesma linha de Zumbi, mas foi formalmente mais organizado: a intenção transparente da companhia foi a de aproximar o fracasso da esquerda, já parcialmente consciente disso em 1967 (ano de feitura e estreia do referido espetáculo), da Inconfidência Mineira, pois ambos foram movimentos que "tinham tudo pra dar certo" e não deram ${ }^{8}$. Havia também a tentativa de conjugação entre elementos naturalistas e épicos (grosso modo, Stanislavski e Brecht), nem sempre bem estimada pela crítica, e o estabelecimento do Sistema Coringa, aperfeiçoado após ter-se ensaiado algumas de suas técnicas elementares no primeiro musical, como veremos à frente, visto que Zumbi ainda não possuía sistematicamente o Coringa: "Em Zumbi,

\footnotetext{
${ }^{8}$ Principalmente no tempo de Tiradentes, o Arena se agitou perante à problemática do papel de artistas e intelectuais em tempos socialmente sombrios, uma vez que, geralmente, estes guardavam o direito de refletir e receitar saídas, nada fazendo na prática - situação com a qual os "arenistas" se identificavam, pelo menos, até 1968, ano do encanto pela luta armada.
} 
todos os atores representavam todos os personagens: a distribuição de papéis era feita em cada cena e sem nenhuma constância; procurava-se mesmo evitar qualquer periodicidade na distribuição dos mesmos papéis aos mesmos atores.” (BOAL, 2013, p. 186).

Considerando esse conjunto, a fase musical do Arena convergiu com um projeto de crítica incisiva do teatro, voltando a trazer o povo brasileiro (representado simbolicamente) para o centro dos espetáculos. Não obstante, sempre tão requerido como público, o povo ia cada vez mais sumindo do quadro artístico; logo, sem conseguir se manifestar, acabava afastado da cultura. Juntando-se os dois espetáculos, é possível ver que as revoltas contadas pelo Arena, assim como as lutas da esquerda artística e política contra a ditadura, sucumbiram pelo simples motivo de não se poder fazer "revolução" sem a presença do povo (uma crítica ao PC presente nas peças) - tão buscado por Boal em períodos anteriores, o povo foi encontrado de forma enviesada pelo CPC no contato direto, prática essencialmente inviável após o estabelecimento do autoritarismo.

Outros traços importantes do imediato pós-golpe, dentro do qual Zumbi e Tiradentes se inserem, foram a relativa hegemonia cultural esquerdista e exatamente o caráter conciliatório do partido citado: os elos perigosos condenados no palco pelo Arena têm como referência mais óbvia as alianças comunistas com parte da burguesia progressista, acordadas antes de 64, algo que se demonstrou uma péssima estratégia depois, quando tal classe pôde se aliar a setores mais altos e conservadores da direita. Schwarz (1978, p. 61-62) ressalta esses pontos: como sabemos, apesar da repressão em diversos setores, o golpe de 1964 - defensor do capitalismo e em oposição ao socialismo - rompeu com a continuidade de um "governo populista", mas não com o grande espaço da esquerda no campo da cultura, o que aumentou nos anos seguintes:

\footnotetext{
A sua produção é de qualidade notável nalguns campos, e é dominante. Apesar da ditadura da direita há relativa hegemonia cultural da esquerda no país. [...] Em suma, nos santuários da cultura burguesa a esquerda dá o tom. Esta anomalia - que agora periclita, quando a ditadura decretou penas pesadíssimas para a propaganda do socialismo - é o traço mais visível do panorama cultural brasileiro entre 64 e 69. Assinala, além de luta, um compromisso. (SCHWARZ, 1978, p. 62)
}

Os seus agentes, segundo Schwarz (1978, p. 62), foram "grupos diretamente ligados à produção ideológica", também os consumidores dessa cultura de esquerda, constituindo, assim, um mercado considerável que fabricava obras para si mesmo (além de materiais de outra ordem para outros círculos) - a explicação para isso é que o golpe interrompeu com violência o convívio entre "o movimento cultural e as massas" de operários citadinos e 
camponeses, por exemplo; contudo, economizando ataques aos intelectuais socialistas, pelo menos até 1968, “[...] não impediu a circulação teórica ou artística do ideário esquerdista, que, embora em área restrita, floresceu extraordinariamente" (SCHWARZ, 1978, p. 62). Esse pensamento de esquerda, ao mesmo tempo limitado e incisivo, para Schwarz (1978, p. 62-63), possibilitou a formação, numa pequena burguesia, "de uma geração maciçamente anticapitalista"; porém, em 1968, ao contrário de 1964, a violência e a censura deitaram sobre a produção cultural, até porque a recepção (de face estudantil) já era uma "massa politicamente perigosa”. Enquanto sociólogo, Schwarz (1978, p. 63-65) aponta para o fato de o PC, a mais conhecida organização de esquerda, ser antes anti-imperialista do que anticapitalista e ter feito uma má avaliação do momento histórico e uma aliança arriscada junto à burguesia (concebendo o seu "marxismo patriótico", avizinhado ao "populismo nacionalista"), sendo os seus principais equívocos de conciliação sumarizados pelo ensaísta: apesar de ter transmitido às massas ideias de relações entre "dominação imperialista" e "reação interna", o partido justificou, com a parte prática disso, a derrota para o golpe - dentro das "classes dominantes", diferenciava "um setor agrário, retrógrado e pró-americano" de um "industrial, nacional e progressista", a quem os comunistas se juntavam para combater o outro, mas, antes disso, dever-se-ia destacar o antagonismo dessas classes com relação aos próprios comunistas; então, desprestigiado pela burguesia, o PC fez de suas alianças um "vasto movimento ideológico e teórico", sendo surpreendido pelo golpe (tal como o presidente, segurando-se no partido e pego repentinamente pelos militares): "Em consequência chegou despreparado à beira da guerra civil. Este engano esteve no centro da vida cultural brasileira de 1950 para cá, e tinha a tenacidade de seu sucesso prático.” (SCHWARZ, 1978, p. 65). Logo, Schwarz (1978, p. 66) desnuda "a deformação populista do marxismo", que, ligando-se ao poder e se espalhando como tese, incidiu sobre as artes e as ciências humanas - nesse caso, a cultura esquerdista virou um negócio -; portanto, com uma política reformista, base de questionamentos feitos principalmente após a implementação da ditadura, o PC não parece ter validado o marxismo de uma boa maneira:

Em consequência, a tônica de sua crítica [da cultura] será o nacionalismo antiimperialista, anti-capitalista num segundo momento, sem que a isto corresponda um contato natural com os problemas da massa. Um marxismo especializado na inviabilização do capitalismo, e não nos caminhos da revolução. (SCHWARZ, 1978, p. 67, inclusão e grifos nossos)

Por último, Schwarz (1978, p. 67-68) assevera a ideologização de um pensamento esquerdista que se submete ao "sistema de conciliações". 
Ainda em 1967, tendo em vista a carência de auxílio monetário governamental, iniciou-se a prática do Núcleo 2 do Teatro de Arena, uma experiência com novos diretores e um elenco paralelo. Quanto ao período subsequente aos musicais, iniciado em 1968 (ponto alto da guerra pela liberdade de expressão, no momento derradeiro em que ainda seria possível obtê-la durante a ditadura), não se inaugurou nenhuma nova fase na companhia, cuja disposição, entretanto, marcou um posicionamento engajado definitivo: cientes de que a ditadura viera "para ficar" e que a censura não recuaria diante de quem expusesse a realidade, mas também sob muitas incertezas, a partir da proposição de Lauro Cézar Muniz, artistas paulistas (juntamente com o Arena) organizaram a I Feira Brasileira de Opinião, um espetáculo-painel, contando com artes de diversas frentes (teatros de segmentos diferentes, artes plásticas, música, cinema, entre outros) e realizando uma colagem de várias manifestações artísticas, inaugurada sob muita censura e consequente resistência:

\footnotetext{
Não sabíamos o que fazer. Cada qual tinha a sua opinião. Qual a certa? Por isso, pensamos em uma feira que seria a das opiniões.

[...] O caminho caminhado se via comprido - muito havia a caminhar. Antes de olhar em frente, vimos trás: ao Arena havíamos dado repertório com nossa cara e voz; depois do espelho realista, nos vimos na metáfora clássica; com o CPC de Santo André, espectadores escreveram peças e personagens e, coroando a libertação, invadiam o palco, atores e personagens. Veio o golpe; recuamos: cantores voltavam a cantar a si mesmos, cada um representando muitos; Zumbi nos permitiu a síntese nós, agora, contando a nossa História.

[...] Devíamos responder: O que pensa você da arte de esquerda? Nós nos perguntávamos para que existíamos. Serviríamos para alguma coisa, suaves artistas, naqueles tempos de guerra? Questionávamos nossa arte, função na sociedade, identidade, nossas vidas. (BOAL, 2000, p. 253-255)
}

Com heterogeneidade e, até mesmo, divergência de ideias, dissipada pela contagiosa coragem, a famosa declaração de Cacilda Becker por "desobediência civil" deu início aos trabalhos, informando que não mais se respeitaria a censura, trazendo à tona a união dos artistas de São Paulo, principalmente (ao decretarem greves em teatros para se juntarem à Feira no Ruth Escobar), e fazendo valer a liberdade de expressão democrática, impulsionadora do acontecimento da Feira. Houve a proibição da estreia e a sua perseguição onde fosse ser representada, dentro e fora da cidade; por fim, o espetáculo acabou sendo liberado momentaneamente por um juiz de esquerda, diante do que começaram ações mais violentas ao teatro (como invasões, sequestros e atentados); depois, ocorreu um habeas corpus, o qual permitiu apresentações e desencadeou clandestinidades - o ataque a Roda Viva, as bombas de gás no Arena, os estudantes da plateia virando seguranças e os atores se armando, tudo em clima de medo, porém, de efusão política. Ademais, como dizia Boal, a 
ética na arte não o satisfazia de todo, mas os artistas não podiam se calar diante da repressão; por outro lado, ao tentar se defender e se engajar nessa luta (a qual a esquerda achava que venceria), o Arena acabava se afastando mais do povo tão desejado e não percebia esse isolamento da classe média, camada de pertencimento dele e do seu público. No texto do programa da Feira - em que também se realizaram assembleias -, Boal dá a medida do seu engajamento, então a cara do Arena no final da década de 60: vendo a cultura internacionalizada e pregando a luta armada, proclama-se contra a arte sobretudo mercadológica e não brasileira em essência, como o Tropicalismo, condenando essa vertente supostamente "vendida" e pouco nacional - aí há uma crítica clara ao Oficina. Visitaremos este texto ainda no presente trabalho.

A partir do que foi dito, vimos o surgimento do Teatro de Arena, em 1953, e uma definição progressiva, comprovando a importância dos passos dados durante a sua história, também enfatizada por Magaldi (1984, p. 8): primeiro, como o nosso teatro vinha indagando um estilo próprio, estudou-se maneiras de "comunicar a fala do autor" (com destaque para a prosódia, falseada pelos antecessores do TBC); depois, a nacionalização dos textos clássicos se impôs ao final da fase fotografia, propondo relacionar-se com a contemporaneidade nacional; logo, a experiência agregadora dos musicais seguiu-se e intercalou-se a isso, apesar do repertório que viabilizava a separação das etapas; portanto: "Da implantação inicial do realismo, o Arena passou ao abrasileiramento do teatro épico de Bertold Brecht." (MAGALDI, 1984, p. 8-9). O passo derradeiro foi o do Teatro Jornal, no Areninha, oferecido pelo Núcleo 2 e debruçado sobre eventos próximos, expondo contrariedade ao regime militar juntamente com um público ativo (ensinava-se a fazer teatro, proliferando técnicas como uma herança a ser deixada). Nessa tentativa de popularização, o exercício de Brecht e de outros conceitos já usados fomentou o espírito que Boal levou para o seu Teatro do Oprimido, concebido na prisão. Finalmente, o grupo se diluiu com o agravamento da ditadura, em $1971^{9}$, enquanto alguns artistas seus estavam na luta armada e quando se deram o encarceramento e o exílio do seu líder, Augusto Boal.

\section{2 (En)cantando Zumbi}

Arena Conta Zumbi faz parte de um período de eclosão de espetáculos musicais brasileiros, ocorrido após o advento do golpe civil-militar de 1964 e que contou, ainda, com

\footnotetext{
${ }^{9}$ O prédio do teatro, por sua vez, pertence hoje ao Serviço Nacional de Teatro (SNT) e abriga o Teatro de Arena Eugênio Kusnet, preservando ao menos a importância história da companhia.
} 
os não menos importantes Show Opinião, abrindo esse filão, Liberdade, liberdade e Arena Conta Tiradentes. Conforme o objetivo deste trabalho, de mostrar, através dessa peça, o caráter politicamente engajado do Teatro de Arena ligado ao momento histórico, veremos que o espetáculo permitiu e participou do clima de trocas ideológicas e culturais (muito misturadas, nesse tempo) entre o seu público, visando à resistência ao regime opressor que se impunha.

Contando com texto autoral de Augusto Boal e Gianfrancesco Guarnieri e música de Edu Lobo (além das colaborações de Ruy Guerra e Vinícius de Moraes nas letras de Reza e Ganga Zumba, respectivamente), o espetáculo musical foi dirigido por Boal - sem autoritarismo, positividade marcante em sua direção crítica - e teve sua estreia no próprio Teatro de Arena de São Paulo. Do prestigiado elenco do grupo, originalmente faziam parte da montagem tanto atores iniciantes como alguns já experientes: Gianfrancesco Guarnieri, Dina Sfat, Lima Duarte, Marília Medalha, Vanya Sant'Anna, David José, Anthero de Oliveira e Chant Dessian. A direção musical ficou a cargo de Carlos Castilho (contando com os músicos Luiz Fernando Manini, Melchior Sawaya Netto e o próprio Castilho), a cenografia e o figurino foram de Flávio Império (já atuando como freelancer para o Arena), a iluminação criada por Orion de Carvalho, a produção arranjada pela atriz Myriam Muniz e a montagem realizada por Antonio Ronco. O espetáculo seguiu para o Rio de Janeiro, no segundo semestre do mesmo ano, com direção artística de Paulo José, direção musical de Dorival Caymmi Filho e elenco e equipe reformulados. Como a peça obteve grandes aplausos de público e crítica, foi apresentada muitas vezes posteriormente à temporada de estreia, já estendida em um ano e meio, sendo a "carta na manga" do Arena, que, com o orçamento apertado, não hesitava em reapresentá-la também em excursões no exterior (Estados Unidos, México, Peru, Uruguai e Argentina, junto com o Teatro Jornal, além do Festival de Nancy, na França) - essas, organizadas a partir de 1969, acabavam se esticando com o êxito da peça e se davam graças à acolhida de países críticos ao AI-5. É interessante lembrar que Zumbi foi encenado na Broadway, anos depois, mesmo sendo um musical ideológica e esteticamente diferente dos americanos, os quais buscavam o final feliz e o entretenimento, sendo ele mais ligado à história e ao paralelismo entre dois tempos, com o seu teor político pioneiro.

O enredo de Arena conta Zumbi, segundo adiantamos, traz à luz a luta por liberdade e a resistência à escravidão, no século XVII, por parte dos negros do Quilombo dos Palmares, sempre sugerindo a analogia crítica deste combate histórico (que durou de 1630 a 1694) com os dias contemporâneos à peça: “A anunciada história 'que se parece ao presente' é uma recriação poética do episódio de Palmares." (CAMPOS, 1988, p. 70). Tendo como base o 
romance Ganga Zumba, de João Felício dos Santos - faz-se um profundo aproveitamento do seu volume, inclusive de cenas, que proporcionam elementos como a fala diferenciada dos escravos, uma mescla de expressões africanas e português estropiado, conforme informa Roux (1991, p. 193) -, o texto também utiliza, por vezes, a pesquisa histórica de Edison Carneiro e lança mão de documentos diversos, ainda que contrariando-os eventualmente.

Guarnieri, em entrevista a Fernando Peixoto, destacou as necessidades, sentidas dentro do Arena, de alterar a forma teatral. Ademais, ficam visíveis a contribuição fecunda de Edu Lobo (espécie de ponto de partida para o trabalho), que chegava ao teatro e potencializava as demandas de criação, e o livro de João Felício dos Santos, que deu ensejo à narração da história palmarina e ao começo da pesquisa. Por fim, em sua fala, vê-se o clima feliz que permeou a concepção toda, coletiva e coordenada pelos autores (até do texto), algo muito comentado pelos artistas que dela fizeram parte, e igualmente, vemos como foi o trabalho de escrita com Boal e o início do sistema de encenação proposto:

\begin{abstract}
A gente sentia que precisava mudar a forma narrativa. Não era uma discussão nova, mas se aguçou neste período, sobretudo depois que chegou o Edú Lobo, que veio chamado antes do tempo, por precipitação do Luiz Vergueiro, Edú veio, achando que existia um texto pronto para ele musicar, mas a gente não tinha nada. A não ser a inquietação. A gente sentia a necessidade de romper com o que fazia antes. Eu tinha a idéia da "sala de visitas". Você pega três atores numa sala de visita e se eles quiserem eles contam uma história, passando do passado para o futuro, do campo de futebol para o Himalaia. Surgiu a magia do "conta". E Edú começou a cantar músicas novas para a gente. Cantou uma sobre Zumbi. A gente passou uma noite de loucura pela cidade e às 8 da manhã estava na praça da República comprando o livro de João Felício dos Santos, Ganga Zumba. Resolvemos contar a história da rebelião negra. Arena Conta. Começamos a pesquisar. Boal chegou. Todos juntos. O elenco junto. Foi uma fase em que tudo se transformava, e a gente também. Dentro da maior alegria, da maior euforia. Todo mundo rompendo com coisas, até no nível pessoal, e todo mundo buscando coisas novas. Época de euforia e alegria mesmo. E Boal organizando o trabalho coletivo. Na hora de escrever, ficamos eu e ele. Foi a primeira colaboração mesmo, em nível de dramaturgia. E a primeira vez que ele dirigiu um texto meu. Quer dizer, nosso, porque meu, mesmo, ele só encenou Animália. Fizemos a escrita final. Não era uma feitura de texto apenas. Pois o texto já supunha uma estrutura cênica, um espetáculo. Era imaginado para um palco vazio, para poucos atores. Era inclusive uma necessidade de produção, que a gente assumia e procurava assimilar no nível da escritura. (GUARNIERI, 1985, p. 57-58)
\end{abstract}

Quanto à "criação coletiva coordenada", Campos (1988, p. 71), tendo assistido ao espetáculo na ocasião de sua montagem, menciona "a diversidade de subsídios" que nele havia, achando imprescindível o engajamento compartilhado com o público para que tudo fizesse sentido: “As contribuições começam pelos textos de que se serve a peça, no final de contas uma vasta colagem, e vai até a participação do público, sem cuja cumplicidade muitos significados se perderiam." (CAMPOS, 1988, p. 71). 
Inicialmente tão inquieto com os aspectos do espetáculo quanto com a conexão deste com a realidade do seu público, Boal fala da sua aversão à "burocracia artística" e reforça a coletividade desde o primeiro verso de Zumbi, em sua biografia:

Como arte coletiva, a formação de equipe é imprescindível, rigor contratual ou laços
afetivos, mas tem que existir.
Existiu, em minha vida, em ocasiões e motivações diversas. Quando eu e Guarnieri
escrevemos e Edu Lobo musicou Arena conta Zumbi, sempre juntos, ensaiando
partes do texto e músicas que iam ficando prontas. À noite, Tartufo de Molière e,
depois do jantar, até de madrugada, íamos autores e atores pra minha casa. Guarnieri
e eu nos revezávamos na Olivetti, os outros em volta, dando sugestões, Edu trancado
em outra sala, compondo.
Juntos criamos essa unidade, esse coração, não só porque éramos família, mas,
ideologicamente, estávamos juntos, lutando contra a recente instalação da ditadura
cívico-militar, que tantos matou e tantos danos irreparáveis causou. (BOAL, 2000, p.
157)

No programa da peça, Boal e Guarnieri (1965) assinam o texto Vivemos um tempo de guerra a fim de dar uma ideia do contexto geral ao espectador. Falando primeiramente de formas novas - existentes em outros círculos, para a então realidade mutável - e das agitações do tempo, além de criticar a imobilidade comum do teatro, os autores sugerem que Zumbi estaria de olho nas mudanças:

Nesta etapa do seu desenvolvimento o Arena desconhece o que é o teatro. Queremos
apenas contar uma história, segundo a nossa perspectiva. [...] Somos um grupo de
gente boa, diretores, atôres, técnicos, autores, eletricistas, porteiros, bilheteiros.
Somos quase vinte. Pensamos parecido. Esta gente reunida, usando o material
disponível, vai contar uma história que tem moral escondida. Uma história que,
esperamos, vai ajudar todo o mundo a entender melhor as coisas ocorridas, e as que
estão acontecendo. Que deve ajudar todo o mundo a ver com maior clareza. (BOAL;
GUARNIERI, 1965)

Sobre a técnica inovadora e os materiais utilizados, Boal e Guarnieri (1965) entregam que há certa "imaginação" na história (ou ficcionalização), tendo em vista as lacunas dos elementos históricos e a grandiosidade que seria requerida pelo espetáculo, se fosse este tradicionalmente realizado:

Dêstes fatos concretos surgiram as novas técnicas que estamos usando em ARENA CONTA ZUMBI: personagem absolutamente desvinculado de ator (todo mundo faz todo mundo, mulher faz papel de homem sem dar bola prá essas coisas, etc.), narração fragmentada sem cronologia, fatos importantes misturados com coisa pouca, cenas dramáticas junto a documentos, fatos perdidos no tempo e notícias dos últimos jornais, anacronismos variados. Só uma unidade se mantém de todas quanto até hoje foram proclamadas: a unidade da idéia. Só uma idéia orientou a criação do texto e do espetáculo. Esta é a idéia contida no texto do bispo de Pernambuco: "o hábito da liberdade faz o homem perigoso". Esta é a idéia: queremos ser livres. (BOAL; GUARNIERI, 1965) 
Considerando a pesquisa e a política implicadas, podemos reafirmar a vontade do grupo de narrar uma história com propriedade, acreditando que nesse fato se originou a sua forma nova, posteriormente convencionalizada em sistema, como veremos adiante. Por fim, ao comparar Zumbi com o espetáculo Opinião, em relação ao enclausuramento a um "fato concreto", os autores expõem o seu objetivo: "Em Arena Conta Zumbi procuramos ir além: usar o fato concreto, mas tendo sempre presente a necessidade de universalização dos dados apresentados.” (BOAL; GUARNIERI, 1965). Portanto, fica clara a existência das alusões, mas o que se enfatiza é a busca pela liberdade e a tentativa de universalizar tal tema.

Além de caracterizar Zumbi pelo tom político (tocante aos momentos em torno do militarismo) e atentar para alguns de seus contrassensos conteudísticos e formais, Costa (2016, p. 119-120) parece enaltecer o trabalho graças ao viés admitido nele para a exposição da problemática da escravidão, que parte da perspectiva do negro e questiona a subordinação histórica deste, revisitando e promovendo um novo exame da nossa história, possivelmente ligando-a às "lutas populares":

\footnotetext{
Posta entre parênteses a situação política em que foi criada, a peça corresponde a uma das mais sérias tentativas, no âmbito do teatro moderno brasileiro, de pôr em cena uma forma de luta contra a escravidão, com a vantagem de adotar o ponto de vista do escravo e de desafiar, por este ponto de vista e pelo recorte histórico (a tática dos quilombos), ideias até então correntes sobre a passividade com que os negros se submeteram à condição escrava - ideias cuidadosamente cultivadas e estendidas aos trabalhadores em geral. [...] Por outro lado, Zumbi em alguma medida é também expressão do movimento intelectual de revisão da história do país, ocorrido em sintonia com o ascenso das lutas populares desde os anos 1950 [...]. (COSTA, 2016, p. 119-120)
}

Costa (2016, p. 123) destaca a opção dos dramaturgos de não focar a peça no personagem Zumbi (como Santos fizera em seu livro), abordando a trajetória da genealogia do rei Zambi; outras qualidades apontadas pela estudiosa são a organização na linha de Brecht e o uso da pesquisa histórica de Edison Carneiro, sobretudo a respeito dos homens brancos, sendo que partes de materiais históricos lá contidos foram dramatizadas e desmentidas, frente à crítica, inapta por ignorar as fontes, que chamou Zumbi de maniqueísta, conforme já revelamos, mesmo este sendo um espetáculo de traços épicos. Aliás, Costa (2016, p. 123) diz que a peça toda - texto, espetáculo, encenação -, ao falar da "luta pela liberdade" (narrando a vida do quilombo desde a captura de seu rei até a sua destruição completa), foi concebida tomando-se "lições aprendidas com o teatro de Brecht", como evidenciaremos à frente, às quais o Arena já vinha sendo introduzido desde antes dos musicais, convergindo com o 
sistema de encenação originado a partir daqui.

Finalmente, em Zumbi, a companhia assumiu a classe média em si mesma e no destinatário da mensagem urgente:

Zumbi foi a cristalização das experiências que havíamos feito. Sabíamos que não
iríamos dialogar com o povo. Mostraríamos a nossa cara.
[...] Em Zumbi, outra vez, a metáfora. Usamos a República Negra formada por
escravos que se libertavam - os capturados ainda escravos, escravos permaneciam
em Palmares, que ocupava superfície maior do que a Península Ibérica. Palmares se
desenvolveu por um século no nordeste do país até ser destruído por uma coligação
de portugueses e holandeses, quando o seu poder comercial ameaçava a hegemonia
branca. Palmares resistiu até o último homem. Numância. (BOAL, 2000, p. 230; 232)

Nossa leitura de Arena Conta Zumbi se deterá sobre os pontos julgados como relevantes em seu enredo e texto, ressaltando-se cenas, situações e trechos que possam contribuir com a ideia de engajamento exposta pelo Teatro de Arena, naquele momento decisivo da história política; depois, destacaremos determinados elementos do espetáculo, em suas estratégias e inovações, com o mesmo fito - embora as matérias por vezes se misturem. Faz-se esta sugestão para efeito de organização do presente trabalho. Eventualmente, e sobretudo ao final do capítulo, outras contribuições serão aproveitadas a fim de corroborar ou colaborar com os argumentos apontados; além disso, exporemos um breve apanhado sobre o teatro épico, teoria com a qual o espetáculo dialoga.

Abrindo o debate, portanto, a peça se divide em dois atos, sendo o primeiro um pouco maior do que o segundo e subdividido em cenas nomeadas. O primeiro ato inicia com uma rubrica indicativa sobre o ritmo, o som do atabaque e a entrada dos atores (no roteiro, diz-se que entram "como jogadores de futebol em campo" e que se dirigem também à plateia), os quais devem permanecer em cena durante toda a peça e fazer diversos personagens - cada um deles possui a sua "máscara" de comportamento, o seu jeito de agir, para ser identificado pelo público. Adiante, falaremos mais de tais aspectos trazidos pelo espetáculo, conforme indicaram os autores no seu programa - uma semente do chamado Sistema Coringa, esquema desenvolvido através de Arena Conta Tiradentes. Seguimos agora com o elenco entoando o canto inicial. Como é sabido, a música é muito presente e, reforçando os argumentos apresentados, tem um papel de destaque no engajamento de viés "pedagógico" que o grupo propõe desde o começo:

1 - O Arena conta a história

pra você ouvir gostoso, quem gostar nos dê a mão ] bis.... e quem não, tem outro gozo. ] 


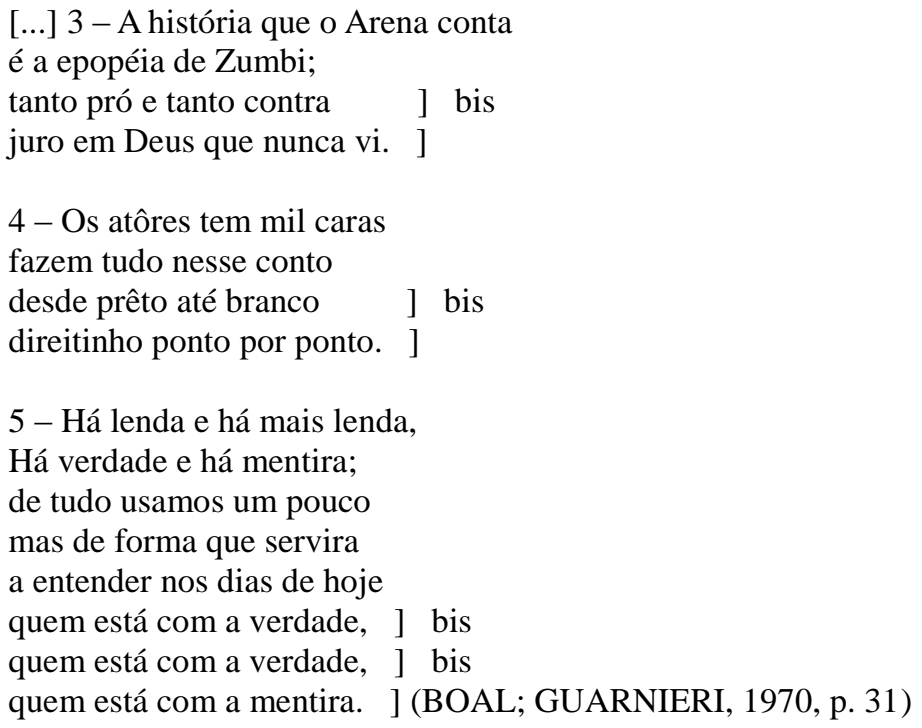

Nesse canto, aparentemente descontraído, o elenco se apresenta e enuncia a maneira pela qual a história será contada ao público, em consonância com o título da peça e os objetivos expostos no programa: o ponto de vista será o do Teatro de Arena; também, já se deixa clara a aproximação do conteúdo vindouro em relação ao momento presente (época logo posposta ao golpe civil-militar), isto é, a intenção metafórica do enredo que versa sobre uma "epopeia"; ademais, explica-se, no texto, o rodízio de atores nas diferentes personagens aspecto a ser revisado. Com um certo nível de provocação, os intérpretes dizem haver verdades e mentiras no que contarão da lenda, com o propósito sempre justificável de compreensão daquilo que se vive. Os versos finais do canto, inclusive, parecem se destinar a irritar os militares, tendo em vista o fato de a mentira (propositadamente) estar ao lado deles e não com a esquerda. Ao final disso, indica-se a escuridão do quadro e, por causa do tom de voz baixo do coro, sugere-se o sentimento de medo, o que também dialoga fortemente com o clima pós-golpe. O fim da cena já introduz a violência física, fazendo referência direta ao açoite (à tortura física), situação na qual estaria o escravo (e preso) Zambi - rei de Palmares, como depois saberemos, conforme a sequência do texto indicará ${ }^{10}$.

A primeira cena propriamente dita vai explorar a violência física do açoite: o canto repete o nome do rei e a história contada (por um ator) lembra-nos dos mortos no confronto, sendo muito maior o número dos que lutam pela liberdade, de modo geral, do que os da

${ }^{10}$ É importante salientar que a história de Palmares e a linha de sucessão de seus reis (a ordem Zambi - Ganga Zona - Ganga Zumba ou Zumbi), é contada pelo texto adotando uma perspectiva sem grandes preocupações históricas, não sendo impreterivelmente necessário o conhecimento prévio e aprofundado do tema para a compreensão da peça, cujo objetivo não é a representatividade do negro e a valorização das questões identitárias, mas a contrariedade à ditadura - o seu fim é politicamente engajado. Assim, vimos que os autores usaram diferentes materiais de base para apoiar os personagens, havendo uma predominância, inclusive na genealogia, das sugestões do livro de Santos. 
guerra de Palmares - a batalha, com períodos de trégua, durou por volta de um século, segundo o texto. Consequentemente, a peça diz pretender homenagear a todos os lutadores por liberdade, grupo dentro do qual o Arena e o seu público se incluíam. O cantador ${ }^{11}$, primeiro personagem a aparecer com fala designada (e sobre o qual a rubrica faz questão de reforçar o fato de ser interpretado por mais de um ator), chama a atenção do público para a imaginação e começa a contar a história aludindo ao contexto africano de 1600, de onde vêm os navios negreiros com os personagens que aparecerão em seguida, como o Rei Zambi. O elenco mimetiza a embarcação e desde já, em função do amontoado de gente, é impossível não lembrar dos porões policiais. O coro sublinha a cena, e, ao final, temos Zambi, amarrado ao centro do barco, posição relacionada à tortura; no entanto, ele demonstra grande coragem e responde ao coro, falando da família que ficou em Luanda - as separações forçadas são destacáveis aqui, igualmente perpassando o tempo presente -, mas, também, sempre revoltado, incita a rebeldia negra, que não vem. O coro, por sua vez, canta a saudade da terra, de Luanda, remetendo-nos ao romântico poema Canção do exílio, de Gonçalves Dias, ao falar nostalgicamente da natureza; porém, paralelamente canta a revolta, a "quebra" de tudo ao redor, pelo incômodo da saudade e da vontade de voltar.

A segunda cena se passa no espaço do mercado de escravos, onde a crueza da compra e da venda é personificada no mercador: ali, a gente negra é produto (com valor monetário), material e volume, como os "terroristas" antiditadura eram um número de presos. O cantador, então, vai contar do açoite de Zambi nas terras de um senhor. Neste momento, há um didatismo ímpar do elenco, em consonância plena com o seu propósito engajado de esclarecer o público por um viés político-social: o texto indica que três atores explicam cientificamente o procedimento da tortura, por intermédio de slides (opcionais, segundo o roteiro), uso decorrente da assimilação de Brecht, como veremos. De resto, é relevante salientar que as técnicas de tortura usadas frequentemente e desenvolvidas na ditadura civil-militar brasileira foram ensinadas a torturadores de outros regimes autoritários sul-americanos, tamanha a eficácia de nossos "carrascos". Por fim, dois atores terminam a cena comicamente: eles aproximam esta vida de provações à vida de Cristo, como se fosse uma coisa boa, fazendo um aproveitamento enviesado de um texto do Pe. Antônio Vieira (cujo nome é proferido por todos

\footnotetext{
${ }^{11}$ Além de mencionar, enquanto heranças presentes em Zumbi, a "revista musical" (no nivelamento de crítica e humor) e o teatro político mundial - agitprop, Piscator e Brecht (no didatismo como fim) -, outra tradição sugerida por Campos (1988, p. 83-85) é a da "cultura popular" brasileira, a qual, apesar de não reger a politizada peça, pode ser percebida através do cantador - elemento narrativo (mas não um narrador), que, como vimos, explica ao público a ação a ser encenada - e da métrica da cantiga nordestina, usada para contar: "Zumbi não se identifica, enquanto projeto, com a crítica simplista e ingênua ou episódica. Aqui o circunstancial é inserido em uma fábula que quer transcender o momento e se dirige, mais do que à crítica, que é apenas um de seus componentes, à análise política." (CAMPOS, 1988, p. 85).
} 
e possivelmente seria um traidor, nessa visão) e da referência ao catecismo, forma "amigável" de convencer historicamente os negros a trabalharem para os brancos e "contribuírem" para as riquezas do país. Diante da energia e do vigor dos escravos, portanto, o branco tem suas ferramentas de controle, como os castigos do cativeiro e as ideias de convencimento, que, no entanto, não interrompem as fugas.

A passagem seguinte é curta e todos se perguntam onde está Zambi, antes de se darem conta da fuga do rei. Nisso, o narrador irrompe para contar a história das fugas e da resistência negra, pois os negros fugidos da violência lutavam por "um futuro sem senhor" em um mundo em liberdade e igualdade, ideal também da esquerda política contrária ao regime militar em voga - neste trecho, a tortura é nomeada como tal, aproximando ainda mais o contexto da peça ao contexto do espetáculo:

NARRADOR: Negros de todos os lugares procuravam as matas fugindo desesperados. Horror a chibata, ao tranco, às torturas. Buscavam no desconhecido um futuro sem senhor. Enfrentavam todo perigo. Fome, sêde, veneno, flechas dos índios, capitães do mato. Agonia pela liberdade. Idéia de ser livre. (BOAL; GUARNIERI, 1970, p. 33)

Por conseguinte, mostrando os personagens negros nas matas, tendo as fugas sido incentivadas pelo episódio de Zambi, a peça nos põe frente a uma questão provavelmente inimaginada, de acordo com o motivo do texto: a incerteza que a ideia de liberdade traz; assim, a abolição como a conhecemos, sancionada pela Lei Áurea, não levou em conta as necessidades dos escravos em um novo tipo de vida. Talvez mantendo essa crítica em vista, a celebração da liberdade se depara com o impasse do personagem Nico, um escravo possivelmente conformado com a sua condição, que conversa com alguns companheiros, expondo-lhes o receio de ser livre, pois não sabe como será o seu futuro e para onde irá, visto que, pelo menos onde estava, ele tinha onde dormir e o que comer. Os restantes, querendo convencê-lo, expõem a utopia da liberdade no desconhecido e o que podem vir a construir nela, mais uma vez exaltando a riqueza da natureza, a ser reforçada na Canção das dádivas da natureza, que menciona alguns elementos naturais (muitos deles, de origem indígena). $\mathrm{Na}$ música, o jogo estabelecido entre Nico e o elenco (às vezes, todos cantam, outras vezes, somente as moças ou os moços) é de antagonismo: as barreiras com relação à fuga são desmanteladas pelas belezas naturais, mas pode-se concluir que Nico sempre "puxa" o otimismo geral em direção ao seu pessimismo, perguntando o que mais há e dizendo não saber lidar com o que tem "lá" (entre fauna, flora, comidas e pessoas). O desfecho da ação nos demonstra intenção cômica, uma vez que Nico pergunta se se poderia "ter mulher" nessa mata 
cheia de qualidades (e o sentido sexual é sugerido), ao que todos respondem não, sendo esta a única resposta negativa; com essa falta, o escravo diz preferir o cativeiro e todos concordam, conferindo humor ao debate - este é o gancho para a ação do sequestro das escravas (situação que soa como positiva também a elas): de pronto, dividem-se as negras em 20 ou 40 "pra cada um"; contudo, a discussão de uma moral machista e misógina não ganha peso na argumentação geral da peça, visando-se antes à descontração do texto, que aborda outros assuntos políticos com mais objetividade - tendência suposta em Nico, simbolizando os esquerdistas mais atingidos pela violência ditatorial.

O quadro seguinte dialoga com o anterior: o título, ao também nomear o samba tocado (Samba do negro valente e das negras que estão de acordo), já indica a opressão e a objetificação da mulher negra, se o analisarmos contemporaneamente:

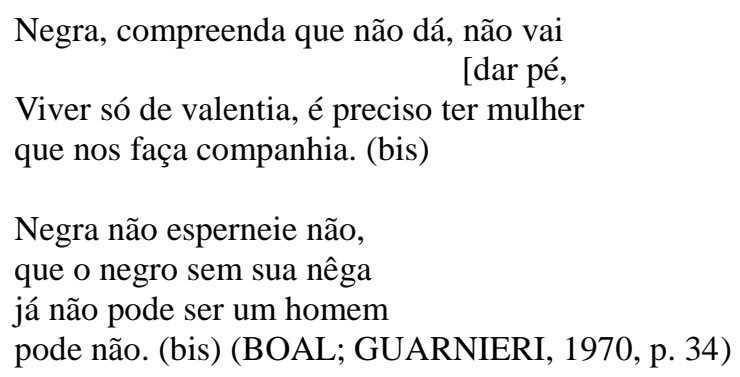

Como podemos ler, canta-se que a mulher é uma necessária companhia, não sendo possível ao escravo somente se contentar com a liberdade; fora que o verso "negra não esperneie não" deixa sugerida a violência sexual e a imposição da vontade do homem, não o "acordo" para que esta fuja com ele; assim, diferentemente do personagem Nico, convencido a fugir, as negras, sem opção, tiveram de aceitar - como o negro deveria aceitar os desmandos do branco. Além disso, novamente aludindo politicamente à situação contemporânea ao espetáculo, ainda que de longe, é possível enxergarmos o fantasma da tortura, na qual as presas políticas eram, muitas vezes, sexualmente violentadas. Continuando: visto os personagens estarem "entre iguais", negros e negras, a cena ganha um tom cordial e a violência parece ser velada em razão do "carinho". Nesse momento, as negras ganham voz na canção, demonstrando o abuso sexual, mas somente o do branco (este traço de realidade é histórico na formação do Brasil: a miscigenação por meio de relações entre senhores e escravas, geralmente não consentidas, porém, tidas como “obrigatórias" ou "normais"); por fim, elas entrariam em acordo com o "seu nêgo" para também serem felizes. Outro ponto importante a ser frisado e que não estava em jogo na década de sessenta é o afeto e a sexualidade sendo dramatizados somente entre homens e mulheres, portanto, demonstrando a 
limitação da igualdade pregada pelo engajamento político - a heteronormatividade do lado negro e, como se demonstrará, a homossexualidade, sugerida sempre do lado branco, enquanto item de humor. Ligado a isso, sabe-se que o Arena, como grupo, e mesmo Boal, não eram muito abertos à homoafetividade; todavia, aqui, pode-se entrever os códigos de compreensão entre o Teatro e o seu público, já mencionados ao falarmos da falta de alcance das peças político-populares.

Campos (1988) aborda essa incongruência, entre outras. Frente ao fato de Zumbi não necessariamente "desvendar os mecanismos capitalistas e a luta de classes", propósito do conflito que visa simbolizar, Campos (1988, p. 77) afirma que a moralidade sobressai do texto em função da falta de investigação das justificativas dos dois lados da guerra (embora componentes como a liberdade e a dependência da metrópole ensaiem motivos) e da afirmação recorrente da luta digna; desse modo, ela tece críticas ao entendimento da peça, cujos elementos ligam-na a um momento e a um público deveras específico (com quem partilha imagens, referências críticas e, mesmo, preconceitos não vistos como tal) ${ }^{12}$. Por outro lado, a nosso ver, essa é uma restrição necessária ao engajamento pretendido, se pensarmos em termos sartrianos de historicidade:

\begin{abstract}
A superficialidade da análise política responde, em parte, a uma limitação autoimposta de atender ao imediato, fazendo de Zumbi uma peça datada, já pelo insistente recurso a alusões que se perdem para quem não tenha proximidade com os acontecimentos. Os melhores lances de humor - e a comicidade é um dos maiores trunfos do espetáculo - se dão sobre referências a fatos próximos. Algumas passagens, inclusive, tiram seu efeito de um comportamento afetivo muito particular a certos grupos.

[...] Também particularidades não-intencionais prendem Zumbi a seu tempo. A uma platéia de hoje certamente não agradaria, por exemplo, o tratamento que, na peça, se dá à sexualidade. (CAMPOS, 1988, p. 77-78)
\end{abstract}

Assim sendo, com desproporções de abordagem no tocante à sexualidade (tomando-se como referência os nossos dias) - a heterossexualidade inquestionável e procriadora do negro e a homossexualidade como tópico ridicularizador, incutida ao homem branco -, Campos (1988, p. 78) ressalta a característica restritiva da peça a tempo e espaço imediatos, o que delimita também uma "capacidade evocativa" em função dessas aproximações, apesar da boa abrangência da temática da liberdade: "De fato, desbastando-se as circunstâncias, resta a fábula genérica da luta do oprimido contra o opressor e a visão lírica de um mundo construído

\footnotetext{
${ }^{12}$ Muito provavelmente, a recepção atual não daria o mesmo significado das plateias de 1965 a Arena Conta Zumbi, que, encarada como uma montagem inadequada, poderia até ser julgada como politicamente incorreta, levando-se em conta as tomadas de humor com indícios machistas e homofóbicos e a situação de o elenco, formado por atores brancos, representar personagens negros, efetuando uma apropriação oportunista da causa negra.
} 
pelo trabalho e pela alegria da liberdade." (CAMPOS, 1988, p. 78).

Seguindo na peça, a rubrica seguinte quebra o clima de concordância e indica a vingança dos brancos (por meio de tiros), uma vez que estes não queriam perder as negras roubadas. Ao ouvirem os estrondos, os negros ponderam sobre as mortes ocorridas no seu grupo e pela desistência em vez da resistência, porque não haveria nada no lugar para onde iriam e seria preciso trabalhar duro na construção dos quilombos - a crítica à abolição parece retornar aqui, na forma de dúvida e debate. Nesta cena, irrompe Zambi, já como o rei de um povo fugido, e tudo se dispõe de maneira que ele dialogue e seja aclamado por todos; enfim, o seu discurso preconiza a liberdade do negro e o trabalho livre na construção de um mundo novo para ser deles, não dos brancos:

ZAMBI: Pois que Zambi é rei, Zambi: vai dar as ordens. É no trabalho que um dia a gente pega o sol com a mão. É no trabalho que se faz o mundo mais de jeito. Em cada coisa que a mão livre do negro encostar novas coisas vão nascer. Não vamos viver só das coisa já nascida, das coisa que Deus deu. Vamos fazer o mundo mais de nosso jeito. (BOAL, GUARNIERI, 1970, p. 35)

A continuação disso, em canto, expõe os elementos a serem cultivados e as atividades a serem feitas (entre materiais, animais e vegetação). Ao final, Zambi demonstra fé (provavelmente cristã), pois toda a riqueza e a gente que ali estavam pertenceriam ao dono Deus, a quem todos agradecem.

Com o título de "Ave Maria", o quadro que se segue vai corroborar isso: Zambi e o coro rezam, evocando todas as "graças" das quais dispõem para viverem bem. Devido ao título e à execução da oração, nota-se que o cristianismo se mistura à religião afro, congregando os diferentes. Nesse ínterim, Zambi pede perdão por crimes cometidos pelos seus companheiros (como mortes, assaltos, roubos, entre outros), "pecados" listados por todos num crescente da cena, cujas repetições são marcantes, com a justificativa de que eles perdoaram os seus senhores. Aqui, tem-se mais uma boa insinuação do regime ditatorial brasileiro, ocorrida quando os presos políticos ou perseguidos comunistas eram tidos como "terroristas" pelos militares.

Na cena seguinte, aborda-se o lado branco do conflito, o qual, cada vez perdendo mais escravos, pede ajuda ao governador da capitania de Pernambuco, Dom Pedro de Almeida (conforme indicado, um homem designado por Deus): as reclamações são de baixo nível e vão desde a importância do número de negros fugidos e "roubados" até a queixa de estes terem levado consigo as negras dos seus prazeres, que não fugiriam, segundo os senhores de terras - entretanto, sabemos que sim, visto elas serem social e fisicamente violentadas pelo 
homem da casa grande. Eles noticiam ao governador a valentia dos escravos e enfatizam o dinheiro perdido, frente ao que Dom Pedro ordena a recaptura e demanda as contas exatas para isso - o Tesoureiro expõe com crueza os números a serem gastos por cada cidade na empreitada. A fala final do governador vai demonstrar desde já a fé cristã sendo usada para o mal (ligada ao dinheiro da capitania), pois Deus e a estabilidade das contas poderiam perdoar os negros, em uma espécie de contravalor moral. Ainda, o cantador, sempre como quem conta a história, indica que as recapturas custariam mais aos senhores brancos do que novas importações, então, "quem fugiu teve perdão", e a solução viria pela água. No fechamento do trecho, o coro canta sobre um navio negreiro que chega, cheio de escravos e violências, para compensar cada fugido, imagem sobre a qual se impõe novamente a da ditadura civil-militar a truculência do regime se mostrou mais agressiva após a promulgação do AI-5, via tortura escancarada, mas, desde 1964, as restrições sociais e artísticas agrediam a liberdade do sujeito.

No plano seguinte, o cantador expõe o carregamento de escravos no qual vinha o angustiado Ganga Zona, "negro de real linhagem", e Gongoba: durante uma conversa entre eles, fica-se sabendo que os dois formam um casal e da intuição pessimista dela, indicandolhe que irão se separar ao chegarem no seu destino, cada um sendo designado a um branco diferente; o companheiro, otimista com seus planos, fala de Zambi (seu avô) com esperança, pois este será procurado tão logo descerem no Brasil - por vezes, a cena é interrompida por uma "voz" e pelo eco do coro, lembrando o mar -; Gongoba acha bonito o sonho do parceiro e chora, encaminhando o quadro para a expressão do seu lamento. A desesperança é um outro elemento marcante na esquerda política, após as pessoas terem se dado conta que a ditadura vinha para ficar, sentimento também comum aos presos políticos, sendo que, mesmo no começo do regime militar, este já habitava a alma de alguns militantes, descrentes nas forças e organizações esquerdistas. Graças à adequação da peça pelo engajado grupo, a plateia, possivelmente, se identificou à tristeza de Gongoba quanto ao seu futuro incerto. Na música iniciada ali, Canção para Gongoba, Ganga Zona quer fazer a mulher parar de chorar e dá a entender o surgimento futuro de alguém bom (um filho deles, embora isso não seja dito); igualmente, através de canção, todos cantam sobre a construção de Palmares, momento no qual o trabalho é muito enfatizado por repetições marcantes e quando Zambi é chamado de rei do lugar:

Trabalha, trabalha, trabalha, irmão

Trabalha, trabalha, de coração.

Palmares tá grande, Palmares cresceu,

com a fôrça do braço do negro que

[sabe o que é seu. (BOAL; GUARNIERI, 1970, p. 38) 
Nessa cena, o rei faz um breve discurso, mostrando a prosperidade e o crescimento de Palmares, havendo já certo tempo que ele fora para lá e tendo formado vários quilombos - a peça se mostra resumida, nesse sentido -; no mesmo caminho, ele saúda e chama cada um e, enfim, incita-os ao trabalho e à liberdade: todos cantam sobre isso, o trabalho servindo ao negro enquanto defesa, ocorrendo também alguns diálogos, entremeados pela música e sempre demonstrando essa cooperação dentro do quilombo, ao mesmo tempo em que outras coisas relacionadas à sua expansão se davam, como os nascimentos, os casamentos e os batismos. Por exemplo, em subcenas cômicas, os negros expõem os seus "nomes de escravo" e ganham nomes novos; logo, um diálogo entre um companheiro e o negro Segé nos bota frente à questão da poligamia: ele é casado com cinco mulheres (e tem filhos com todas elas), tudo dentro da lei, como faz questão de dizer, algo que é exposto com humor para enfatizar como Palmares ia se desenvolvendo rapidamente, por meio de crianças que viriam a ser a sua continuação no futuro, e não pelo viés da problematização da poligamia, mas da prosperidade. O fechamento da cena nos leva ao encontro de uma parte imprescindível do enredo: o trabalho livre do negro dava muitos frutos, e, antevendo vantagens econômicas, os brancos comerciantes desejaram comprá-los (algumas cidades são mencionadas como compradoras de mercadorias quilombolas); assim, com as vendas, os negros adquiririam armas daqueles para defesa própria, e o elo comercial se estabeleceria entre os diferentes.

A próxima etapa do texto versa sobre esse comércio de troca. Segundo o cantador, Palmares produz muita coisa; logo, nessa relação de compra e venda, o branco quis se aproximar do negro explorado, sugerindo relações de amizade. Aqui, por sua vez, entra a voz dos brancos, algo muito marcante na peça: o espaço de fala em prosa desses homens livres parece ser sempre possibilitado, apesar do maniqueísmo e dos traços ruins designados a eles, pois os negros, no texto, possuem mais voz em canções e versos, deixando os brancos predominarem no tom épico e ficando eles com o dramático - esta característica voltará a ser estudada na posterior abordagem dos gêneros manipulados. Portanto, cantando, os comerciantes parecem ser os "bons brancos", que valorizam o trabalho do quilombola, negro vindo de tão longe, para quem vendem armas e com quem supostamente se entendem. Ainda na cena anterior, temos a deixa para a pacificidade: 


\begin{abstract}
pra cada cana vendida, se compra muita espingarda pra defender nossa vida.
\end{abstract}

Negro vende e branco compra branco vende e negro compra, branco dá e negro dá,

é um danado de trocar. (BOAL; GUARNIERI, 1970, p. 39)

Entretanto, o cantador nos traz o contraponto dessa relação, porque não há paz total: os donos das sesmarias desejam a guerra, não essa harmonia intencionada pelos comerciantes. Os senhores, então, declaram quererem de volta aquilo que lhes pertenceria, os corpos dos negros fugidos; ao mesmo tempo, a paz sugerida seria falsa aos seus olhos, significando "a vitória do subversivo", algo a nunca ser admitido. Nesse rumo, o termo utilizado, "subversivo", derivado de subversão, ressalta um outro paralelismo com o presente, já que esta também foi uma palavra-chave na ditadura para classificar os perseguidos, comunistas ou não, artistas ou não. Logo, a exortação às lutas vem ao palco na forma de um tipo de grito de guerra. Os comerciantes cristãos, negando apoio ao conflito, indicam proteção aos negros e agem como um canal de comunicação entre os extremos; os negros, por sua vez, continuam cultuando o trabalho (repetidamente, no tocante ao texto) e sendo iludidos por essa ajuda em formato de defesa; no entanto, confiando no laço, eles cantam o desejo de parar de comprar armas e a notícia do aumento de preços das suas mercadorias, achando que serão bem compreendidos pelos aliados, o que, na verdade, ocasiona uma reviravolta na ação geral; obviamente, os comerciantes tomam o partido contrário: eles mencionam a sua fé cristã novamente e querem punição contra essa rebeldia, finalizando a aliança amigável pela mudança de atitude.

\title{
CORO DE NEGROS:
}

Trabalha, trabalha, trabalha, irmão que o branco vai nos defender, contra o branco que nos quer perder, mas armas não é preciso não por isso chega de comprar, agora vamos só vender, os preços temos de aumentar o branco vai nos entender.

\section{COMERCIANTES:}

Nós os brancos comerciantes, nos guiamos pela bíblia o livro santo prevê êste caso no Evangelho de Ezequiel:

- Com a rebeldia não há concórdia. Punir com firmeza é uma forma de demonstrar misericórdia. (BOAL; GUARNIERI, 1970, p. 40) 
$\mathrm{Na}$ sequência da canção, os dois grupos brancos se unem para acabar com a "subversão" e novo grito vem à tona, agora pela destruição do povo negro. Neste ponto, sugere-se a metáfora com o maior potencial de ter sido bem compreendida pela recepção da peça, a das alianças do Partido Comunista com determinados setores progressistas da burguesia, ocorridas antes do golpe e que acabaram sendo prejudiciais à esquerda - como trouxemos ao expor o argumento de Roberto Schwarz. Ademais, a alusão da peça é crítica, pois parte da esquerda não aprovava essas aproximações, ou seja, a união seiscentista ocorrida e a virada de posição dos comerciantes foram usadas para representar a crítica do Arena às arriscadas alianças do partido: “A história, aqui, foi simplificada e teve um desfecho precipitado aparentemente para fins de demonstração do teorema de setores da esquerda que criticavam a política de alianças do PCB no pré-64.” (COSTA, 2016, p. 125).

Apontando para o fato de a aliança comercial empregada na obra ser historicamente verídica, Campos (1988, p. 76-77) afirma, contudo, não ter sido esse o motivo da destruição dos quilombos, apesar de esta ser a leitura suscitada pelo grupo, a fim de que, perseguindo referências à situação contemporânea, se criticasse a conciliação definidora entre esquerda e burguesia - no entanto, esta é uma ponderação branda, dado que o elo equivocado, no texto, é visto como sinal de "generosidade" ingênua dos escravos (de quem se assume o ponto de vista), por consequência, não se incutindo culpas individuais quanto ao movimento fracassado nem opções para ultrapassá-lo, sendo a consciência dele já suficiente para o levante da militância:

Para muitos, já o vimos, essa aliança atreladora [PC e burguesia progressista] teria sido a principal causa da desarticulação das forças populares diante do golpe militar. Assim também entendem os contadores de Zumbi e tiram a lição: os diversos setores da classe dominante podem ter contradições entre si, mas não tão fundamentais que os impeçam de se unirem caso o povo ameace de algum modo seus interesses. Os setores "amigos do povo" só o são enquanto este servir a suas ambições, caso contrário, são capazes de se somarem aos grupos sociais mais retrógrados para esmagar o inimigo fundamental. Com isso, critica-se uma direção incorreta dada ao movimento político. Não se apontam, no entanto, responsáveis pelo erro de condução. Na peça do Arena, a simpatia estende-se sem restrições aos derrotados, como se todos só muito tarde tivessem alcançado a compreensão de sua falha e esta fosse consequência, não de uma análise insuficiente e incorreta dos fatos, mas de uma generosidade, traço positivo que só deve ser afastado devido à malícia e violência do inimigo.

[...] Em Zumbi, o ângulo de visão pretende ser o do povo derrotado, o de todos os empenhados na luta, tornando-se, assim, coletiva a responsabilidade por erros e acertos. No mau destino, unificam-se os que participaram, de algum modo, de seu traçado e todos são redimidos pela mensagem positiva semelhante à que se vira em Eles Não Usam Black-Tie [...]. [...] em Zumbi tudo se passa como se a compreensão do erro fosse o bastante para sua superação e reversão da derrota. Não se indicam novos rumos, mas se insiste na continuidade de uma luta que, conforme a 
dedicatória, “dignifica o ser humano". (CAMPOS, 1988, p. 76-77, inclusão e grifos nossos)

Depois disso, outra tomada se impõe e se dá a narração das derrotas dos brancos nas primeiras investidas contra Palmares: o Capitão João Blaer, junto do seu diário de viagem, é apresentado como o homem designado para ir aos quilombos destruir tudo e recuperar os negros rebeldes. Desse modo, expõe-se dia a dia os seus feitos, que são, porém, meio ridículos, acontecendo somente no décimo segundo dia o seu encontro com os quilombolas, pois ele parece procrastinar bastante - tal como os policiais contrafeitos a fazerem parte do golpe civil-militar, que serviam a um dever. As analogias continuam e a plateia, até onde se sabe, percebia-as facilmente. Enfim, o décimo terceiro dia seria o da volta após a ruína, passagem na qual os soldados são tratados como efeminados pelo Arena, tamanho o escarnecimento dos "feitos". Quanto a esse episódio de 1645, porquanto os autores, via pesquisa, verificaram que nem tudo poderia ser verdade nos documentos históricos antevistos, decidiram eles desmentilos, diminuindo os valentes heróis brancos por via cômica, inclusive requerendo, no roteiro, que a atuação os mostrasse "fresquíssimos todos, afetados, artificiais". A cena seguinte, intitulada "Cacos oficializados", relaciona-se a esta situação, havendo números romanos indicativos da sua justaposição à cena do diário: nela, demonstra-se certo preconceito do texto no mesmo sentido da anterior (xenofóbico e homofóbico), mas isso não entra em questão na crítica política do espetáculo. O que se enfatiza, com intenção de humor, ridicularizando os brancos, são alguns estrangeiros (possivelmente soldados) conversando sobre os lugares e as naturezas conhecidas no caminho e misturando idiomas em suas falas ao contarem como foi a expedição.

Costa (2016, p. 125-126) chama o referido trecho de "interregno holandês" e nele destaca o receio da recepção com relação à passagem, tudo em função do desenho pejorativo empregado no retrato dos brancos em questão (com clara ridicularização de sexualidade), o que explicaria as derrotas sofridas; ainda, como a encenação queria desnudar a falsidade dos materiais históricos, empregou-se uma determinada atuação, conforme apontamos, não dando lugar para o entendimento geral de que o exemplo técnico era brechtiano:

Numa cena muito mal recebida, por lançar mão inclusive de alguns preconceitos discutíveis (a caracterização dos holandeses como efeminados), Boal e Guarnieri, até mesmo pelo recurso às bichices no palco, procuraram sintetizar o fracasso das expedições holandesas (foram duas, historicamente) - o que significou um longo período de sossego para os palmarinos. Além disso, apoiados nos documentos do livro de Edison Carneiro, os dramaturgos aproveitaram o ensejo para ilustrar o caráter mentiroso da maioria dos documentos sobre essa guerra. A direção, recomendando aos atores que fossem "fresquíssimos todos, afetados, artificiais", 
acabou provocando mais protestos do que observação do problema exposto e impediu a percepção de que a cena foi tecnicamente inspirada em recursos como os utilizados por Brecht em A alma boa de Setsuan e já experimentados por Vianinha e Chico de Assis na Mais-valia, assim como pelo próprio Boal em sua Revolução na América do Sul. (COSTA, 2016, p. 125-126)

Logo, o cantador irrompe novamente para noticiar ao público que Ganga Zona, parente do rei do quilombo, está a caminho, preso em um navio, sendo mais tarde destinado a uma senzala e separado de Gongoba (então grávida, fato do qual ele não fazia ideia) - este recurso, comumente nomeado como "quebra da quarta parede", será comentado posteriormente. Prosseguindo: na chegada do Ganga, surge um capataz empurrando os negros do navio para o seu dono, D. Fernando, um homem supostamente melhor, mas ameaçador aos escravos. No diálogo "secreto" ocorrido entre um outro negro e Ganga Zona, no caminho para as terras deste senhor, fica-se sabendo que o dono não é um bom sujeito e que seria praticamente impossível fugir de suas terras depois de chegar a elas; assim, o negro influencia o neto de Zambi a sair logo e diz ser encarregado, por seu avô, de resgatá-lo e enviá-lo aos quilombos. Tal é o plano de fuga exposto pelo cantador, elemento seguido por uma oração de Ganga Zona.

A última ação deste ato se inicia com a formação do quadro: são indicados música seiscentista e cantador, bem como o painel de uma festa no palácio do governador. É interessante observar que os ambientes são raramente indicados pelo texto; no geral, a sucessão se dá naturalmente - as passagens ocorrem com base em elementos visuais (luz, som, ações, entre outros) e nas palavras do texto -, visto não haver cenários elaborados no espetáculo, do que melhor falaremos adiante. Mostra-se também, sob muita bajulação, Dom Ayres Bezerra, capitão a quem o público é apresentado: fica sabido que este homem lutou contra os negros e, dentre os seus, foi o único sobrevivente; todavia, não temos acesso a essas batalhas durante a peça. Na sequência da reunião entremeada por quadros de humor, o mordomo apresenta a todos o governador Dom Pedro de Almeida e, em tal ponto, o efeito cômico para zombar dos ricos senhores retorna, demonstrando a figura imponente a dificuldade de falar e respirar (ele chega, até mesmo, a dormir durante o seu discurso), além de o texto indicar "improviso" aos atores. O atrapalhado governante finalmente consegue elogiar Portugal contra os holandeses e quanto às suas conquistas pelo mundo, pois, ironicamente, o seu objetivo é a liberdade; a partir daí, sempre aclamado, ele vai discorrer contraditoriamente sobre a liberdade e pela escravidão, enfatizando a inferioridade do povo negro (como se o seu racismo fosse "vontade de Deus") e chegando ao absurdo de dizer que “a escravidão dignifica o negro". Passado isso, não seria forçado o argumento de que a sua 
fala é anacrônica, se considerarmos os pronunciamentos militares mais sórdidos, nas preparações da tomada de poder:

DOM PEDRO - Há algo melhor que a liberdade? Não há. A liberdade é a glória de uma coroa, a glória dos bem nascidos. (*) Mas póbres valôres da nossa sociedade se se admite que o negro, naturalmente inferior, por vontade de Deus destinado ao cativeiro, que não o infelicita, mas ao contrário, o humaniza - a escravidão dignifica o negro! integrando-o na sociedade na posição que lhe compete. Eis a ameaça que pesa sôbre o Brasil. (BOAL; GUARNIERI, 1970, p. 42)

Os outros presentes, em concordância, contam-lhe sobre a sociedade que os negros querem, ou ainda, "ameaçam" construir, muito melhor do que a deles, e alguém sugere uma lei contra a mestiçagem, suposto radicalismo ao qual Ayres se opõe (aqui, a sacada é cômica), como se o fato de eles serem portugueses lhes desse o direito adquirido sobre os corpos das negras. Assim, a famigerada "infiltração negra" - em mais uma clara aproximação da peça do Arena com o regime político do seu tempo, sugerindo a referência à expressão "infiltração comunista" - era um perigo e se deveria alertar os compatriotas. Quanto a isso, Dom Pedro pensa em uma nova campanha contra o terror, contando com as mulheres para tal tarefa.

Como na ditadura brasileira, a conquista da opinião pública era algo essencial nessa missão, dado explorado na ação seguinte, dando-lhe nome: na cena, que começa ao som do internacional iê-iê-iê (ocorrência negativa, conforme examinaremos ao listar os gêneros musicais), canta-se contra os negros, representantes de um perigo iminente (oposto à tradição, provavelmente europeia e cristã, e às filhas brancas, a quem eles seriam violadores e malvados). Os enunciados da peça se avizinham aos de militares dos anos de repressão que surgiam, pois eles tentaram convencer a população veementemente, sobretudo a mais alienada, da positividade do regime imposto e da criminalidade de seus opositores da esquerda e dos "libertinos" (artistas), muito através dos meios de comunicação de massa (rádio e TV). A partir de então, mudando o foco, o cantador vai discorrer sobre o nascimento de Ganga Zumba, "filho rei", fruto do amor de Ganga Zona e Gongoba - a escrava não fugira aos açoites da fazenda à que chegara, mas "deu a luz um filho grande", o qual ela escondia ser herdeiro de um ganga. Antão, como o menino é chamado, só agora fica sabendo de sua origem, devendo ir para Palmares viver sob a proteção e os ensinamentos de guerra do rei Zambi, seu bisavô, para depois ele mesmo vir a governar os seus: 
Consequentemente, temos a presença de sinhá Clotilde em cena: esta, ao ver uma agitação, ordena ao feitor o açoite de Gongoba, que sente já poder morrer, visto ter cumprido a sua missão na vida, conceber Ganga Zumba; nisso, o coro intervém cantando baixo a música do açoite. Em seguida, a sinhá está junto a um padre e, através do discurso de ambos, pode-se inferir uma censura à Igreja, porque a religião reiteradamente foi utilizada por gente mal intencionada, ligando-se a algum poder: segundo ambos os personagens, que se creem bondosos (uma ironia ácida do texto), é necessário haver repressão aos escravos, os quais não são mais como antes (homens fortes e mulheres "parideiras"). Nesse momento, todos somos avisados da morte de Gongoba em decorrência da tortura, alguns versos da música do açoite voltam com o coro, e a metáfora é forte, referindo-se aos dias de repressão iniciados no contexto presente do espetáculo. Diante disso, Clotilde e o padre, pessoas horríveis, continuam a conversar normalmente: ele lamenta a morte da negra, que ficara sem a extrema unção, e a sinhá sente "uma pitadinha de remorsos", do que o padre faz questão de liberá-la, culpando somente o feitor e novamente demonstrando a ironia absurda do texto nesta passagem. Isso deixa claro que o branco, principalmente se detém poderes, sempre se livra das penas - mais uma similaridade com a situação dos militares, cuja maioria não era punida pelas violências deliberadamente cometidas em nome do Estado. Ao final, os dois ponderam sobre uma negra substituta e o coro engrandece a canção do açoite ali entoada ( $O$ açoite bateu), como se fizesse um epílogo da vida da escrava. O quadro triste muda e diz-se que Ganga Zumba foge correndo e parecendo feliz, até ser alertado por alguém para ter cuidado: através da conhecida canção Upa, negrinho, todos cantam o seu crescimento, pensam no seu destino, que infelizmente é apanhar, e lhe dão ensinamentos, indicando também uma aguardada liberdade.

Na cena seguinte, ao som de rufos, Dom Pedro se informa sobre as perdas dos seus homens, concernente às batalhas contra os negros (nas quais houve muitas mortes e raptos de mulheres brancas), ato que é seguido pelo seu oferecimento de um acordo de paz aos quilombos, aceito por Zambi. O momento pacífico e festivo, graças à ausência de mortes futuras, é, porém, interrompido pela agressividade eclodida na música do quadro que se inicia. De imediato, outro acontecimento decisivo e transformador do andamento da peça se dá: um arauto da coroa nos comunica a destituição de Dom Pedro e nomeia Dom Ayres de Souza de Castro como o novo governador da capitania, parecendo sarcasmo a sua qualificação enquanto "dono e senhor de atos enérgicos e resolução": 
ARAUTO - Em nome de sua Alteza real que Deus Guarde e da Coroa Portuguesa, faço saber a todos os moradores desta capitania que hoje, dia $1^{\circ}$ de julho de 1788 , hei por bem destruir a Dom Pedro de Almeida do seu cargo de Governador, para o qual nomeio Dom Ayres de Souza de Castro, dono e senhor de atos enérgicos e resolução. (BOAL; GUARNIERI, 1970, p. 45)

Assim sendo, o coro, anteriormente feliz, canta o golpe a Dom Pedro - de novo, as lembranças contextuais não enganam: no Brasil de Jango, não havia perfeição, mas o presidente era de esquerda (não revolucionário, como dizia Boal) e tínhamos progressos consideráveis antes de 1964, fato desmantelado pelos acordos do golpe civil-militar, ocorrido no ano anterior ao da presente peça. As semelhanças continuam: nesta passagem, em sua posse, Dom Ayres expõe uma intenção de governo impopular e toma posição contrária à ideia de independência - o trecho é basicamente colado de um pronunciamento do governante ditador Castelo Branco (aqui parodiado), em outra referência direta à realidade concreta impassível, frente à qual o texto nos coloca:

DOM AYRES - Senhores, da discussão nasce a sabedoria. Opiniões diversas devem ser proclamadas, defendidas, protestadas. O dever do Governador dessa Capitania é a todos ouvir, porém deve agir exclusivamente segundo lhe ordena sua própria consciência individual. Sejamos magnânimos na discussão, mas duros na ação. Plurais na opinião, singulares na obediência de minha ordem. Descontentes haverá, e sempre. Um govêrno enérgico toma medidas impopulares de proteção à coroa, não aos insatisfeitos. Meu governo será impopular, e assim, há de vencer, passo a passo dentro da lei que eu mesmo hei de fazer. Senhores, vós guerreais como quem faz política. Eu farei política como quem guerreia. Vossas entradas são derrotadas pela pluralidade de opiniões e partidos de pensamento. Minhas entradas serão vitoriosas pela unicidade do ataque. A independência é necessária na teoria, na prática vigora a inter-dependência. Não é aqui, neste Brasil, que as decisões políticas devem ser tomadas: é na Metrópole, nossa Mãe Pátria, a quem devemos lealdade, a quem devemos servir como vassalos fiéis. Nossos bravos soldados valentemente lutaram contra o estrangeiro holandês. Nossos heróis formavam um belo exército: já não necessitamos de exército. Necessitamos de uma força repressiva, policial. Unamonos todos a serviço do rei de fora, contra o inimigo de dentro. (BOAL; GUARNIERI, 1970, p. 45-46)

Nesse ponto, o espírito da retomada guerra transparece. Em contrapartida, o final do ato é marcado pelos dizeres do coro sobre a celebrada chegada de Ganga Zumba a Palmares, onde a felicidade em relação ao acordo de paz ainda reina, algo corroborado pela música, que incita as idas para o quilombo - enquanto as mudanças ocorrem do lado dos brancos, permanecem sendo ignoradas pelos quilombolas. Logo, o cantador se dirige à plateia, rompendo novamente a parede imaginária, e anuncia o intervalo com o objetivo de que todos descansem.

O segundo ato de Zumbi é iniciado por dois cantadores: um anuncia o término do intervalo (promovendo a mesma aproximação com o público utilizada no encerramento do ato 
anterior), pois os atores continuarão contando "a estória em bom contato" sobre a guerra entre ex-escravos e homens brancos; já o segundo expõe o contraponto latente entre a paz dos quilombos, com o bom trabalho e a felicidade de Ganga Zumba, e os arranjos da cidade, que armava um plano para surpreender o inimigo. Diante dessas organizações de ataque, como não lembrar das mancomunações militares, precedentes a 31 de março de 1964, indo com tudo para desbaratar o governo democrático de Jango? Na peça, o coro atesta o clima de planejamento, trazendo-nos a figura austera de Ayres e o seu anúncio: ele nomeia Fernão Carrilho, homem engrandecido por ele, como Capitão-Mór de Campo com o fim de "prender, torturar, castigar e matar" - exatamente como a tortura policial veio a realizar nos anos de regime autoritário que se seguiram e que começavam a mostrar uma dura face em 1965. Em todo esse processo, é importante destacar o caráter legal incutido, confirmado pela presença de um escrivão na cena, ou seja, o capitão tem licença para matar livremente, em mais uma aproximação com o contexto político sessentista. Nisso, o coro traz à tona o que comumente é dito sobre a nomeação e o quanto todos se sentem perdidos sobre o que fazer imediatamente, tendo em vista o medo do recomeço das batalhas. Logo, acontece um diálogo entre Carrilho e Capistrano, através do qual ficamos sabendo da declinada de participação de muitos dos homens prometidos para a guerra, assim como dos fornecedores de armas. A partir disso, Carrilho discursa aos soldados disponíveis, incitando-os à guerra e rebaixando os "escravos e covardes"; ainda, Dom Ayres ordena a primeira batalha contra os supostos traidores, a cidade de Serinhaém, que lhe negara auxílio; por fim, o coro canta a guerra do branco contra o branco, dando continuidade à dúvida a respeito do futuro (as repetições no texto marcam a importância do assunto). Quanto a isso, recordemos que a incerteza do porvir já viera ao texto junto da personagem Gongoba, agora morta, e nas falas biográficas do próprio Boal, na ocasião da Feira, pré-AI-5.

O segundo ato não tem divisão de cenas expressamente, então, tentar-se-á dividi-lo em quadros de ação a fim de realizar uma melhor exposição. No quadro que se instaura, temos um diálogo prosaico entre o crescido Ganga Zumba e Dandara, sua companheira, seguido pela Canção de amor sem letra e por outra conversa, agora entre ele e um negro, o qual parece interromper a cena para anunciar a ida do capitão para Serinhaém, o estrago total lá feito e a captura de Ganga Zona, seu pai. Isso posto, o coro grita sobre a morte do negro (genericamente), havendo, na retomada do diálogo, o anúncio da morte de Ganga Zona. Frente à inação e à velhice do rei Zambi, Dandara sugere que o parceiro tome providências, mas ele se opõe a tal conduta, sendo a sua fala final muito semelhante à da esquerda política brasileira pré-golpe - enquanto se perde em seus valores, ele menciona um momento bom de 
se viver: "GANGA ZUMBA - E foi na hora que nóis estava mais calado, no melhor viver da vida correndo. Pra nóis não tem descanso.” (BOAL; GUARNIERI, 1970, p. 48). O coro ainda adentra a cena para cantar a música do açoite, tortura repetida na vida do negro e do esquerdista político, tal como acontece com a canção mencionada durante o espetáculo. $\mathrm{O}$ final da presente ação é um dos pontos de maior engajamento da peça, porquanto demonstra o cansaço do negro de sofrer violências e a ideia de luta contínua como uma saída de resistência a isso, a situação em que foram colocados os indivíduos:

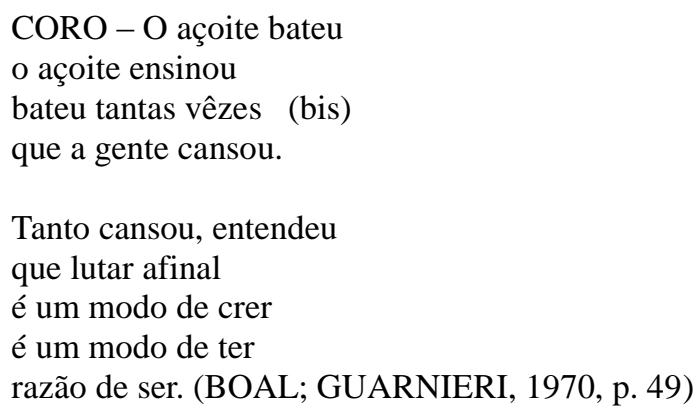

Em Tempo de guerra, o trecho alusivo à falta de júbilo também tem caráter repetitivo e é muito importante como argumento dessa canção, que retornará ao final da peça:

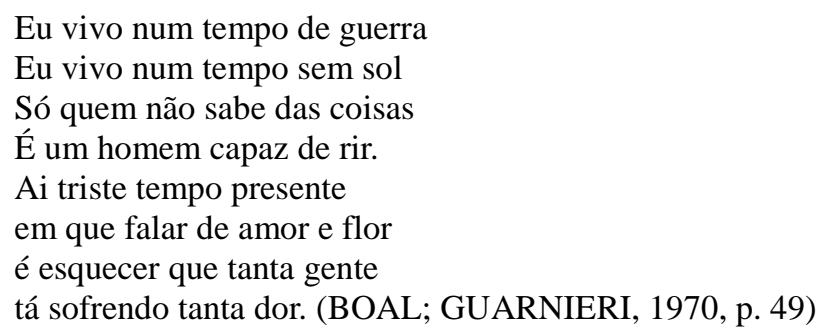

Nessa passagem, Zambi se dirige ao bisneto Ganga Zumba, filho do finado Ganga Zona, para dizer-lhe que ele será o futuro rei de Palmares (somente quando "reis velho cufá primeiro"), pois ele mesmo está velho, e dar-lhe muitos conselhos (inclusive no tocante ao que este teria a aprender com os brancos, que constituíram um governo), destacando-se a sua linguagem mais oral - este traço já aparecera pontualmente, sobretudo nas falas dos negros, não sendo o seu uso aleatório, antes advindo dos materiais de base adotados pelos autores, como apontamos. A seguir, ele enfatiza o "tempo de guerra", de tristezas e gente sofrida, onde a diversão não tem lugar - diversas relações se sobrepõem com o clima de repressão que ganhava corpo em 1965: 
gente no tempo da revolta. Assim passei os tempo que me deram pra vivê. Eu me levantei com a minha gente, comi minha comida no meio das batalha. Amei, sem ter cuidado... Olhei tudo que via, sem tempo de bem ver... Assim passei os tempo que me deram pra viver. A voz da minha gente se levantou e minha voz junto com a dela. Minha voz não pode multo mas gritá eu bem gritei. Tenho certeza que os donos dessas terra e Sesmaria ficaria mais contente se não ouvisse a minha voz... Assim passei os tempo que me deram pra viver. (BOAL; GUARNIERI, 1970, p. 49)

Novamente em um chamamento à luta, o coro canta o tempo obscuro, e Zambi continua a discursar como quem se despede, lembrando-se das coisas que viveu - suas falas finais, entremeadas à letra da canção, são inspiradas em um poema de Brecht, Aos que vão nascer. Além do mais, o trecho deixa subentendido o fim da vida de Zambi e demonstra a resistência do triste presente em tom exortativo, quer dizer, o grupo se dirige ao público inconformado com as derrotas políticas, engajando-o diante disso com esperança. Após a retomada do coro de Tempo de guerra, Zambi se fere com um punhal para que o jovem parente assuma o trono; portanto, ele morre sem conhecer a terra do futuro, de possível paz. A morte é cantada, em seguida, e uma volta sua fica sugerida em cada criança nascida no quilombo. Finalmente, Ganga Zumba assume posição contra os brancos, pela igualdade e a favor da luta em honra de Zambi, desejando vingar os seus antepassados: imediatamente, ele ganha poder e é aclamado Zumbi.

No quadro seguinte, temos um diálogo entre Ayres e o Bispo de Pernambuco, no qual, mais uma vez e principalmente aqui, a religião do branco se mostra perversa: parecendo argumentar contra, o religioso profere coisas terríveis a respeito da figura do "paulista" (ou "bandeirante") Domingos Jorge Velho, o novo comandante encarregado de combater Palmares, após Carrilho ter sido o primeiro a conseguir vitórias para os portugueses. Segundo o texto, este seria um homem mau e selvagem, casado e infiel (tendo várias índias concubinas), vilão e caçador de índios; por isso, o sujeito ideal para a empreitada, conforme conclui positiva e absurdamente o padre, congratulando a decisão do governador. Logo, o homem mencionado, que nos lembra os militares torturadores (uma vez que o roteiro pinta-o como “o mais repugnante possível”), entra na conversa: a sua fala "Estado e Igreja em perfeita harmonia!" nos indica incisiva crítica dos autores a essa situação, por intermédio de algo que ocorria escancaradamente no Brasil pós-golpe, este, um acontecimento político muito apoiado por setores religiosos. Campos (1988, p. 75-76) também aborda a atuação pérfida da Igreja nos anos sessenta, colocada ao lado da extrema direita ditatorial, que tomava o poder do Estado (as "marchas-com-deus-e-a-família" e as condenações à "infiltração comunista" são exemplos assustadores disso), um fato presente na peça através da “dominação ideológica", executada pelo uso do texto de Vieira e por "trechos dos Evangelhos 
fundamentando as opções interesseiras", no tocante aos comerciantes cristãos, além do fato de que é o bispo quem dá o aval ao bandeirante destruidor de Palmares.

Continuando, Domingos faz suas exigências ao governador e demonstra a ambição de querer ele próprio fundar uma cidade como pagamento; Ayres, por sua vez, cobra os planos de guerra, diante do que ele, ironicamente, diz pretender a paz, expondo a sua estratégia de guerra bacteriológica: o ideal seria isolar os inimigos das trocas mercantis e matá-los de fome, por doenças (mediante negros contaminados por pestes a serem enviados aos quilombos) e com incêndios (aos que insistissem na resistência), realizando "um nôvo tipo de guerra". A tenebrosa conversa se finda com Ayres elogiando os bons defensores paulistas e o bispo se mostrando racista e a favor do extermínio do povo negro, dado que a liberdade era vista como um perigo - neste caso, há um comentário de base da peça, conforme citado pelos autores no programa, acrescido de nova analogia com o regime militar, concernente ao pensamento extremista. A religião, num caso e noutro, é um tipo de abono para a guerra, até porque o bispo concede a benção a Domingos, ficando ao lado dos portugueses.

Sobre o surgimento de Domingos Jorge Velho na peça, ele se dá através da colagem de excertos de um documento pouco modificado (uma carta permeada por elogios, enviada do bispo de Pernambuco ao rei, aqui transformada em conversa entre o religioso e Ayres), o que Costa (2016, p. 130-132) mostra ter saído da pesquisa de Carneiro e ter exposto o mal-estar causado na recepção pela "encenação de documentos" históricos - a pesquisadora dialoga com a posição crítica de Décio de Almeida Prado (ainda a ser examinada) quanto ao maniqueísmo do texto na oposição dos personagens, um recurso melodramático através do qual o Arena atingiu o seu propósito:

Temos aqui um outro caso de emprego das lições brechtianas que teve o poder de irritar corações paulistas. A simples encenação de documentos produzidos no século XVII pela própria classe dominante levou Décio de Almeida Prado a escrever, muitos anos depois, que isso era prova de maniqueísmo e ingenuidade dos dramaturgos e do conjunto da esquerda [...]. (COSTA, 2016, p. 131)

Referente ao "episódio da disseminação da varíola" (a doença não é nomeada na peça), rico em recursos e relacionado a Domingos Jorge Velho, Costa (2016, p. 132-133) afirma que nele são elegidas como base a literatura de João Felício dos Santos e a síntese como opção esclarecedora: “Como o 'plano de paz' de Domingos Jorge Velho sintetiza aproximadamente vinte anos de guerra, Boal e Guarnieri trataram de incluir nele também a 'tática da guerra bacteriológica' [...]." (COSTA, 2016, p. 132); ademais, esse uso do material literário ou lendário, em detrimento da pesquisa (possuidora de valas e inverdades, mas da qual também 
foram representados trechos na íntegra), foi priorizado pelos autores, segundo expusemos na questão da linhagem palmarina.

Encerrados os últimos acordos, o coro retorna, agora expondo um "ritual litúrgico em honra da primeira investida" contra Palmares, mais uma vez demonstrando os laços de um dos polos do conflito com a instituição religiosa: o ponto de vista do branco prega o extermínio do negro pela reza, além de fazer menções a Deus; os cantadores, em contraponto, exibem o lado dos negros, que se protegiam como podiam enquanto o valente Ganga Zumba tomava a frente do combate diante do clima de ódio, dor, mortes e fé no novo rei, ele mesmo (enviado por Deus). Em tom exaltado, ele chama os seus à batalha e à resistência, ao que cada quilombo responde - a cena faz lembrar das revoluções republicanas -; ainda, tendo em vista as primeiras derrotas brancas, todos desdenham de Domingos, o qual nem pertencia ao lugar, mas fora chamado para matá-los. O coro do culto retorna, querendo o fim dos negros (chamados de "demônios") e relacionando fé e guerra novamente, pois fala muito em nome de Deus - isso é entremeado pela confabulação dos soldados sobre o medo de pegar as doenças dos negros empesteados. Na sequência, o coro dos negros grita, conclamando Zumbi dos Palmares: o quadro mostra-o ordenando providências para o confronto (com armas envenenadas e sacrifício dos doentes para ir em direção aos brancos), ao passo que Domingos ordena os seus soldados (ele arrebanha índios comprados com "fumo e cachaça" para morrer primeiro, no fronte, e depois organiza as filas). Sabe-se, finalmente, das primeiras vitórias brancas. O coro do culto e o tema dos negros se intercalam: o primeiro, mostrando neutralidade entre bons e maus, noticia a vitória de "frieza, fôrça e inteligência"; o segundo chama Zumbi, que, por um lado, quer resistir e lutar até o fim e faz um apelo aos irmãos dos quilombos, e, por outro, ficando com a ausência de respostas, autointitula-se "Zumbi dos Palmar" e ordena a luta aos restantes - atitude, ao final, inútil, já que sabemos não haver saída. Frente a isso, o coro entoa a morte do negro (através do retorno de outro canto) e se pede a rendição de Ganga Zumba ao cativeiro. Finalmente, a canção Venha ser feliz volta a tocar enquanto Ganga Zumba, parecendo emocionado, discursa de maneira semelhante ao bisavô, evocando os feitos e sofrimentos de sua vida "por querer liberdade", expressão que é repetida por todos os companheiros:

GANGA ZUMBA - Eu vivi nas cidades no tempo da desordem. Vivi no meio da gente minha no tempo da revolta. Assim passei os tempo que me deru pra vivê. Eu me levantei com a minha gente, comi minha comida no meio das batalha. Amei sem tê cuidado... olhei tudo que via sem tempo de bem ver... por querer liberdade. A voz de minha gente se levantou. Por querer liberdade. E minha voz junto com a dela. Minha voz não pode muito, mas gritá eu bem gritei. Tenho certeza que os dono 
dessas terra e sesmaria ficaria mais contente se não ouvisse a minha voz... Assim passei o tempo que me deru pra vivê. Por querer liberdade. (BOAL; GUARNIERI, 1970, p. 54)

Aqui, compreende-se que os negros se entregaram sem a intenção de fazer isso, não havendo final possível a Zumbi senão a morte de Palmares inteiro, então subentendida; os fatos que a relatam, num crescente ritmo, acontecem rapidamente - esta é outra crítica feita ao andamento da peça. Ademais, a canção chamada de engajada durante a presente análise, Tempo de guerra, também retorna no encerramento exortativo do espetáculo, que afirma o seu compromisso politicamente engajado diante da situação brasileira imediata com o elenco se prostrando para a plateia, de joelhos e punhos cerrados (conforme informa o roteiro), simbolizando os negros derrotados e a interminável resistência:

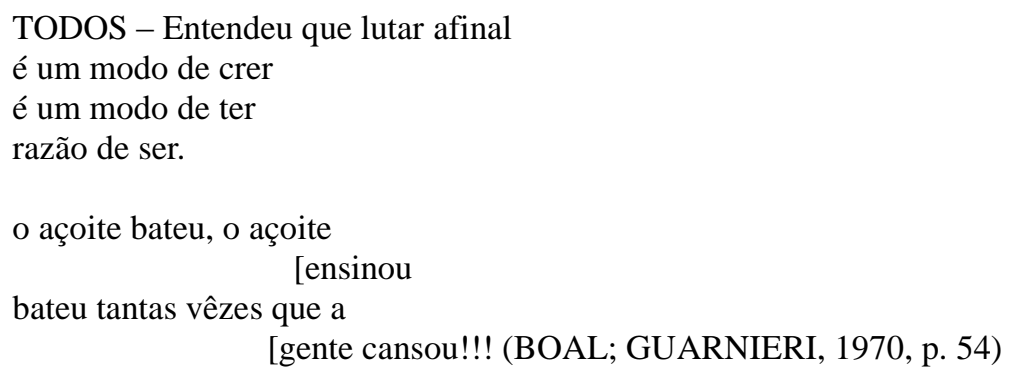

Tal processo é seguido por um ator que conta e anuncia o final do espetáculo, ressaltando a fidelidade do que foi contado ao acontecido na história (discutível, visto que sabemos da existência de ficção e condensação) e reforçando o distanciamento brechtiano presente no espetáculo.

Ao longo do enredo, como pudemos ver, reside uma esperança, talvez infundada, no próprio engajamento de parte da nossa esquerda política da época (representada analogamente pelos escravos), que não admitia o perigo do golpe civil-militar e o baque sofrido com isso, reduzindo-o a uma passagem superável pela luta (tópico comentado por Schwarz, que ainda visitaremos), porém, frente ao qual não era possível fazer muita coisa, em termos concretos. Tal ambivalência marca a obra em vários momentos, pois o fim trágico e o engajamento por um porvir parecem inconciliáveis. Quanto a isso, Campos $(1988$, p. 73) caracteriza o fim da peça como exemplar, com o lado negro sempre em exaltação da resistência (não aceitando sucumbir), contando-se, inclusive, com a canção sobre um vindouro mundo bom e livre, dirigida ao público. No entanto, como a ruína ocorre, seria possível ao público entrever as razões disso e aprender com a desgraça - aspecto didático por excelência: 
Apesar da insistência nos passos da tragédia, a peça não leva ao horror diante da derrota, mas se encerra, ao contrário, por uma exortação onde se afirma a validade da luta.

[...] Existe, desde o início da peça, o cuidado de reduzir o significado da derrota, tomando-a não como definitiva, mas como um episódio na guerra que ainda se pode vencer.

[...] A exortação à continuidade da luta sustenta-se em parte na descrição idílica desse mundo livre onde "o homem ajuda o homem", mas o que principalmente a justifica é a tentativa de compreender e mostrar as causas da derrota, as quais, em suma, podem ser reduzidas à desproporção das forças que se enfrentam: de um lado, a malícia e a violência armada do branco; do outro, a ingenuidade, o desejo de paz, para usar uma expressão brechtiana, a "bondade desarmada" do negro. (CAMPOS, 1988, p. 73-74)

Ligado a isso, é pertinente elencar algumas opiniões sobre as finalidades de Zumbi. Campos (1988, p. 74) destaca as vitórias dos negros, ávidos por liberdade, nos primeiros conflitos em Palmares; todavia, logo, “os negros se deixam vencer”, segundo o teor da peça, ao confiarem em alguns elos mentirosos (fato sobre o qual cai a culpa) e se enfraquecerem para a pesquisadora, com quem estamos de acordo, isso dialoga com o paralelismo a 1964 e a intenção de fomentar a resistência no tempo presente, objetivos da peça:

Não é gratuita essa visão dos fatos. Como nos previne a proposição da peça, "de tudo usou-se um pouco, mas de forma que servira a mostrar, nos dias de hoje, quem está com a verdade, quem está com a mentira" (p. 31). A fábula tem caráter exemplar, endereço certo e, para tanto, motivos bem calculados. A inserção de diversas referências ao presente relembra constantemente a que época se devem ajustar as lições extraídas do evento narrado: o episódio de Palmares será a metáfora dos acontecimentos de 1964. Pretende-se analisar o golpe de abril, a derrota das forças populares, expondo suas causas de modo a subsidiar uma atitude de resistência. (CAMPOS, 1988, p. 74)

Por outro lado, pensando nos anacronismos de Zumbi, ali adequados à história contada, para Costa (2016, p. 134), é possível que a peça diga respeito ao contexto de 1964, mas ela defende, acertando o tempo, que se alegorizam sobretudo os conflitos democráticos ocorridos antes do golpe, havendo desajustes na aproximação (pela desigualdade entre a resistência centenária de Palmares e a da esquerda antimilitarista dos anos sessenta, para ela, praticamente nula); em 1965, a ditadura ainda era vista como temporária, sem possuir o peso histórico que teve, então, o público se via facilmente nos fortes quilombolas:

Por este ajuste da perspectiva cronológica, veremos que Zumbi pretendeu ser uma alegoria das lutas travadas no período anterior a 1964, não podendo o seu desfecho ser comparado ao golpe militar sem que se incorra em mistificação. A razão mais evidente é conhecida demais: enquanto Palmares foi exterminado depois de cem anos de luta e sucumbiu após resistir lutando a vinte anos de escalada militar, em 1964 os golpistas simplesmente não encontraram nenhum tipo de resistência organizada e por isso puderam executar suas metas ferozes (prisão e matança de lideranças populares) com relativa facilidade. Como se sabe, o principal efeito desse 
contravapor sobre a esquerda foi a total desmoralização de suas direções institucionalizadas - o PCB e o PTB, resultado histórico que só vai aparecer como problema, tratado em forma alegórica, na próxima peça do Arena, Tiradentes. Em Zumbi ainda se trabalha com a impressão de que 1964 não passava de um acidente de percurso, por isso a imediata identificação do público com os valorosos guerreiros palmarinos, que lutaram até o último homem e ainda deixaram de herança para os pósteros uma entidade como Zumbi, assemelhada a um orixá (no sentido das teogonias iorubás). (COSTA, 2016, p. 134)

Destacando o perfil dos frequentadores do Arena na época, na maioria estudantes de esquerda, constatamos que a respeito do "lado bom" ou do "herói”, tomadas de posição na estrutura da peça, os negros são personagens já considerados positivamente pelo público, e, porquanto a sua imagem deve significar fora da cena, ela é identificada naturalmente com a esquerda política (através do coro), deixando os brancos representarem os militares. Costa (2016, p. 134-135) trata com naturalidade a identificação ocorrida, já prevista pelos autores; entretanto, a pesquisadora faz uma colocação com a qual não concordamos, embora seja válida: a de que o paralelo entre as intervenções democráticas (anteriores ao golpe) e quilombolas, “[...] determinando, no texto e no espetáculo, uma discutível organização dos materiais (tópicos, episódios, técnicas etc.) resultou numa obra estética e politicamente falsa." (COSTA, 2016, p. 135).

Diante do uso majoritário da fonte literária e tentando descobrir o motivo de "o complexo lado palmarino da história” (predominantemente na retaguarda) ter sido “empobrecido" pelos autores, até mesmo na questão de gêneros teatrais, Costa (2016, p. 135136) vê nisso uma mistura "de paranoia e má-fé", algo que resulta em uma apreciação um tanto desajustada do processo ditatorial por parte do Arena, com a intenção, na peça, de fazêlo ser análogo ao combate seiscentista. Posto que reconheçamos a importância da obra, sabemos que aproximar um esboço de movimento democrático do pré-64 (e quase que inexistente depois do golpe a ser respondido) a um conflito de resistência histórica pode ser generalizante e acabar diminuindo a epopeia negra, ou seja, conta-se a história da guerra por liberdade, indo rapidamente até o seu fim devastador, mas desvia-se de lutar, simbolizando uma resistência política que não acontecia de fato:

Paranoia, porque não há outro nome para a pretensão de identificar um processo de três anos de luta declarada (da vitoriosa luta pela legalidade, que garantiu a posse de João Goulart, à derrota de 1964) a uma guerra sangrenta que levou aproximadamente cem anos para restabelecer a ordem escravocrata em Pernambuco. E má-fé, porque essa identificação forçada exigiu o rebaixamento da estrutura dos palmarinos, sobretudo no aspecto militar, transformando sua organização, sua inteligência tática defensiva e ofensiva e, enfim, suas providências práticas em angelicais votos de boas intenções. A injustiça tem mão dupla porque nem mesmo as lutas do pré-64 ficaram apenas nas declarações de intenções. Mas é uma injustiça 
altamente reveladora da generalização apressada que estava em curso nos "balanços" elaborados após o golpe: como as direções sucumbiram à derrota sem luta em 1964, da constatação desse fato à alegação de que não houve lutas no período anterior basta dar um passo - que, de um modo geral, com mais ou menos ênfase, tanto a esquerda quanto a direita deram. O primeiro passo do Teatro de Arena de São Paulo foi Arena conta Zumbi, produzindo esta espécie de paradoxo que procuramos reconstituir: a pretexto de contar a história de um dos nossos mais importantes processos de luta pela liberdade, Zumbi evitou justamente os episódios da luta propriamente dita, restringindo-se a encenar o seu capítulo final, em que são dizimados os que queriam "apenas" a liberdade, em evidente contradição com o $1^{\circ}$ de abril de 1964.

A ideia de que Zumbi é uma resposta ao golpe militar contém implícito um grão de mistificação. Supõe a avaliação de que o "acidente de percurso" não foi uma derrota e, impertérritos, os guerreiros da véspera continuam a postos para os próximos enfrentamentos. Assim Zumbi foi entendida, como já tinha acontecido com Opinião. $\mathrm{E}$, por isso, ambas as peças foram festejadas como a senha para uma resistência política que não tinha acontecido nem estava acontecendo. Quando o nosso teatro político começa a se dar conta de que em 1964 o caminho democrático, apenas entrevisto nas lutas que Zumbi não conta, estava definitivamente bloqueado para a nossa história, a própria ideia de resistência já tomava outros rumos. E o teatro, longe de resistir, começaria a abandonar as frágeis conquistas do teatro épico. (COSTA, 2016, p. 136)

Além de objetar a ausência de área comum entre os dois lados da guerra, para ser possível medir essas forças, e de demonstrar a fraqueza política do texto, visto que a afirmação da luta recai em ideologia, Campos (1988, p. 88-89) critica a realização como um todo, a qual não correspondeu ao que constava em seu programa, sobretudo quanto à falta de função elucidativa dos fatos e porque concretizou uma catarse (empreendida por terror e riso), “[...] principalmente se em nome dos recursos épicos contidos na peça esperarmos dela uma postura racional que suscite uma reação do mesmo nível no espectador.” (CAMPOS, 1988, p. 89). Contudo, isso pode ser entendido se tivermos em mente a circunstância de este espetáculo ter sido o primeiro a fazer um exame do que se vivia após o golpe civil-militar, sendo concebido pouco tempo depois disso; melhor dizendo, para Campos (1988, p. 89-90), é válida a intenção trazida com a peça de acalmar os ânimos, que, exaltados, poderiam desunir uma possível resistência, antes de realmente agir - a peça agrega e exprime as solicitações da época e da plateia por meio do teatro mais conscientemente do que ocorrera com Black-Tie, pois, como é sabido, a sua recepção estável era constituída de massa engajada politicamente, que compartilhava do mesmo arsenal ideológico que o Arena, todos querendo investir contra o desmonte autoritário ao que vinha sendo criado socioculturalmente antes da ditadura. A união se dava satisfatoriamente através do espetáculo:

A esse propósito vêm servir o desrespeito com que se tratam os textos e personagens históricos, a caracterização do inimigo com traços de boçalidade e decrepitude, o figurino que impõe um modelo que serve à contestação jovem. Não é gratuito o humor grosso como o dos "cacos oficializados" [...]. São elementos que se somam 
ao ritmo frenético, à exibição da plasticidade dos corpos, à simplicidade das canções, no vitupério a uma ordem rançosa e na afirmação de padrões novos. (CAMPOS, 1988, p. 90)

Naquela atmosfera de entusiasmo, talvez estranha, na qual a peça foi feita e encenada (referida em entrevistas), examinando-se o que se passava no cotidiano ditatorial de fora do teatro, essa parcela artística e esquerdista, a que o Arena e o seu público pertenciam, foi se ensimesmando cada vez mais e, conforme Campos (1988, p. 90), rompendo com a reles realidade a que visava destruir e contra a qual sempre incentivava a luta dos seus - embora não se soubesse da possibilidade de fazê-lo, se ela viria a sucumbir ou se só ficaria no plano das ideias, como geralmente ficavam as propostas das classes médias e dos reduzidos teatros. Segundo dissemos, este aspecto foi até mesmo referenciado por Boal, na época da Feira, em que as coibições e violências estavam prestes a explodir, como um fator de afastamento entre o Arena (e os estudantes burgueses) e o tão procurado povo. Campos (1988) fecha o seu estudo com algumas considerações a respeito dessa conjugação e da felicidade rebelde do tempo de Arena Conta Zumbi, além de falar sobre a sua tentativa de alegre lucidez.

Visto isso, por agora, faremos o levantamento de alguns elementos concretos do espetáculo, seguidos pelas concepções formais pensadas por Boal na direção, relevantes para que possamos visualizar melhor o engajamento do Arena. Para começo de conversa, fora a movimentação, que é de muito valor - considerando-se o pequeno elenco utilizado -, quanto à indumentária, temos todos os atores neutramente vestidos com calças jeans claras (brancas) do tipo "lee", como informa o roteiro, botas pretas e "camisas esporte" de manga (cada um com uma cor). O uso dessa roupa, projetada por Flávio Império, o mesmo artista responsável pelo cenário e que só conheceu a peça em seu estágio quase final, a nosso ver, facilita o entendimento da recepção sobre o jogo proposto pela própria encenação (a qual trazia ingredientes como, por exemplo, o desempenho de todos os personagens por parte de todos os atores). Ainda, o depoimento do cenógrafo ressalta o fato de ele ter brincado com a condição de classe média dos integrantes do teatro (ao contar aquela história), também o fazendo quanto ao cenário minimalista, composto por três praticáveis (um ao fundo do palco e dois aos lados, menores) e um tapete grande e vermelho:

Quando eu cheguei, estava pronto. Eles me mostraram o espetáculo. Ainda estava cru, mas estava todo estruturado. E quando acabou, eu morri de rir. Falei: "Parece um bando de intelectuais, no tapete do pai, tomando uísque e conversando sobre o povo..." E a cenografia que eu fiz, foi exatamente essa. Conversando com o Boal, ele falou: - Olha, é isso mesmo, você tem toda razão, faça.

Mexi pouco com a estrutura do teatro, resolvi revestir o chão, de um tapete caro, de nylon e bem felpudo, inclusive brilhante, uma coisa cafona de turco rico. 
Era um tapete vermelho bem grande, que a gente ganhou, e forrou o piso inteiro. E era vermelho de propósito, como uma brincadeira. E a roupa de todos eles era uma roupa que a pequena burguesia usava para ir nas universidades: calça Lee, blusão e blusa de couro [na verdade, botas de couro]. Como eram sete atores/cantores peguei as cores do arco-íris e distribuí - cada um ficou com uma camiseta de uma cor sobre as calças de brim branco. Então ficou essa idéia, a peça se passava como se fosse na sala de visita de uma família burguesa e rica contando a história do povo.

Zumbi tinha muito poucos elementos de cena. A música e a poesia tinham um caráter totalmente descritivo, elas contavam como eram as coisas e os próprios atores, na coreografia, criavam movimentos no espaço abstrato que ajudavam a descrever o lugar da ação, como quando faziam os gestos da ação de plantio. (IMPÉRIO, 1985, inclusão e grifos nossos)

Acerca do uso dos jeans em Zumbi, é interessante refletir sobre a fala de David José, em entrevista a Izaías Almada, na qual ele dá o tom político das escolhas de Flávio Império e discorre sobre o fato de este item não contradizer a forma e as ideias do grupo e do espetáculo, mesmo que a roupa estabeleça relações com a americanização e a massificação cultural, justamente em um tempo de afirmação nacional - contraditoriamente, a indumentária poderia ser considerada transgressora, ligada ao surgimento do rock:

O período de 1964 a 1968 foi um momento de ruptura. Os anos 1960 são anos de ruptura, não só no Brasil, mas em todo o mundo. A Guerra do Vietnã, o maio de 1968 na França, a invasão da Tchecoslováquia. O maniqueísmo então era evidente: ou você era um burguesinho ou era uma pessoa de esquerda. A ruptura se deu contra a perspectiva de construção de uma sociedade mais igualitária, a partir de uma concepção socialista. Digamos que o "espírito da época" ainda continha um grande pendor antiimperialista, antiamericano. [...] E o Arena continuava ali, firme, preparando uma peça sobre Zumbi, sobre a escravidão e a colonização portuguesa, uma reflexão sobre a falta de liberdade, um libelo contra a ditadura. Um dia, durante os ensaios, surgiu o problema de como seriam os figurinos dos atores. O Flávio Império, um dos nossos maiores cenógrafos e figurinistas, muito inteligentemente, sugeriu que o elenco todo, oito atores e atrizes, usassem jeans, os jeans americanos mesmo, importados, com botinha de couro e camisetas coloridas, nada mais americanófilo, pois, naquele momento...

[...] Essa foi, na altura, a grande sacada do Flávio Império, que todo o grupo, incluindo o Boal, compreendeu e aceitou. Se os adolescentes e os jovens da época se identificavam culturalmente com a Jovem Guarda, com o rock'n'roll, com a guitarra elétrica, ainda com os Montgomery Clifts, James Deans e Marlon Brandos do cinema americano, com seus jeans, camisetas, botinhas e casacos de couro, com aquela cultura importada do Texas de Bush e da dourada Nova York, era uma síntese de forma e conteúdo ver o Lima e o Guarnieri de jeans e botinha de couro, de camisetas coloridas. Aquilo era moderno, mas o que se discutia era a liberdade, a luta dos negros em Palmares como metáfora do que se vivia no Brasil naquele momento. Não era Nova York, era o Brasil da ditadura, era o Brasil do Teatro de Arena ou como era visto pelo Arena. (LESSA MATTOS, 2004, p. 114-115)

Ademais, ouvindo-se o áudio da peça, torna-se indiscutível a alta qualidade musical do espetáculo, majoritariamente de autoria do então jovem compositor Edu Lobo, que brindou a montagem com vitalidade, brasilidade e instantes poéticos, conforme enfatizou Roux (1991, p. 196-197). Na fase dos musicais, o Arena explorou muito essa veia, vendo na música uma 
confirmação para as ideias que apresentava no palco, principalmente as políticas, e acabou auxiliando, com isso, o desenvolvimento da MPB, simultâneo aos musicais, pois algumas das músicas feitas para espetáculos tiveram vida independente depois das temporadas. Na peça em questão, certos sentidos vindos do texto, como a distinção entre os dois lados do conflito, são ratificados pelos gêneros das músicas tocadas durante a representação, o que garante o predomínio, dentre os personagens negros, dos ritmos africanos, da MPB e do samba, e entre os brancos, de hinos religiosos e do iê-iê-iê vindo de fora (isso lhe confere negatividade em função do imperialismo), por exemplo. No entanto, apesar de a canção ser muito elogiada, Prado (1987, p. 68), em crítica feita à peça ainda em 1965, aborda esse ponto, para ele, um tanto prejudicial, conquanto enalteça como adequados outros elementos técnicos do espetáculo, segundo ele, "agressivo e inteligente", como a forma de "contar" e a competência do elenco (com destaque para os atores Dina Sfat e Guarnieri, também notados por João Apolinário): para o crítico, a música de Edu Lobo acaba por "abafar o texto" da peça e comprometer o equilíbrio do conjunto, não obstante possuir comunicabilidade, uma vez que a música no teatro serviria antes para suplementar o texto quando preciso fosse "uma mais poderosa expansão lírica ou satírica":

\footnotetext{
Por outro lado, entretanto, o título é perfeito: a história não é vivida mas apenas narrada pelos atores. Estes não se apresentam como personagens mas como narradores, atuando sempre coletivamente. A mesma pessoa - Zumbi, por exemplo é representada por este ou aquele intérprete, dependendo das circunstâncias e sem nenhum prejuízo para a clareza do espetáculo. É uma técnica original e bastante efetiva dramaticamente. O cenário compõe-se somente de dois ou três acessórios e um opulento tapete vermelho, que faz as vezes de pano de fundo: Boal, como encenador, tende cada vez mais a projetar os atores sobre o chão.

[...] Arena Conta Zumbi lembra freqüentemente um comício político cantado e dançado: um frenesi de movimentos, de rumor, com muito poucas perspectivas realmente novas. Sound and fury - será esse por acaso o novo ideal do nosso teatro de esquerda?" (PRADO, 1987, p. 68)
}

Boal (2013, p. 174) considera Zumbi o grande sucesso do Arena - artístico e de público -, tanto por ter se desconstruído com a abordagem histórica que sugeriu, por meio de dois conflitos análogos e "uma ótica moderna", quanto pela renovação formal praticada, porque até então os esquemas eram geralmente restritivos, contrariando uma evolução estética: 'Zumbi culminou a fase de 'destruição' do teatro, de todos os seus valores, regras, preceitos, receitas etc. Não podíamos aceitar as convenções praticadas, mas ainda era impossível apresentar um novo sistema de convenções." (BOAL, 2013, p. 174). Assim sendo, uma amostra disso é o emprego pontual das "convenções do teatro naturalista": conforme diz Boal (2013, p. 174-175) e como vimos, o Arena, principalmente entre 1956 e 1960, ligou-se 
bastante à linha realista, que, em dramaturgia e interpretação, estava de acordo com a "necessidade social e teatral" de retratar a aparente "vida brasileira", valendo-se da fotografia; mas, como o grupo não é estética e ideologicamente estanque, havia disponibilidade para a adoção de demais esquemas que convergissem com as demandas "estéticas e sociais" deste "teatro atuante" na realidade, o que aconteceu a partir de Zumbi (com algumas técnicas básicas):

Zumbi, primeira peça da série “Arena conta...”, descoordenou o teatro. Para nós, sua principal missão foi a de criar o necessário caos, antes de iniciarmos, com Tiradentes, a etapa da proposição de um novo sistema. A sadia desordem foi provocada por quatro técnicas principais que se usaram. (BOAL, 2013, p. 175)

Dessa forma, dentro da relevância de Arena Conta Zumbi enquanto renovação formal em nosso teatro, deve-se destacar novamente o fato de este ser um espetáculo no qual Augusto Boal, como diretor, pôs em prática os elementos básicos do que seria mais tarde o Sistema Coringa, método de encenação desenvolvido como tal no musical histórico seguinte, Arena conta Tiradentes.

Concernente às quatro técnicas presentes em Zumbi e já desenhadas durante o presente texto, podemos mencionar, juntamente com Boal (2013, p. 175-177), a primeira, conhecida como desvinculação entre ator e personagem, que acontecia desde o surgimento do teatro (na Grécia, a tragédia era representada por um elenco pequeno com máscaras) e em cujo exercício, para os musicais, foi preciso abdicar da ascendência realista do grupo e da consequente investigação dos atores por um personagem em específico, uma vez que, na desvinculação, nenhum papel é interpretado sucessivamente e relacionado a um intérprete, todos eles podendo fazer todos os papéis - certos preceitos brechtianos praticados, a serem retomados logo mais, ligam-se a isso, reforçando a coletividade e a ação de "contar" contida no título da peça. Assim, o público identifica os personagens pelas máscaras gestuais ou traços, logicamente menos especializados, o que leva o elenco a um trabalho de diferenciar o essencial e o circunstancial em cada personagem. Portanto, dialoga-se com Brecht, que pregava o ponto de vista único sobre um personagem, entre os atores; no entanto, a técnica se diferencia do distanciamento épico, no qual o personagem pertencia a um ator, pois, em vez disso, os papéis transitam de um a outro:

No nosso caso, tentamos também a utilização de uma máscara; não a máscara física, mas sim o conjunto de ações e reações mecanizadas dos personagens. [...] Em Zumbi, independentemente dos atores que representavam cada papel, procurava-se manter, em todos, a interpretação da "máscara" permanente de cada personagem interpretado. 


\begin{abstract}
Assim, a violência característica do Rei Zumbi era mantida, independentemente do ator que interpretava em cada cena. A "aspereza" de Don Ayres, a "juventude", de Ganga Zona, a "sensualidade", de Gongoba etc., igualmente não estavam vinculadas ao tipo físico ou características pessoais de nenhum ator. É verdade que as próprias aspas já dão uma ideia do caráter genérico de cada "máscara". [...] Porém Zumbi era texto maniqueísta, texto de bem e mal, de certo e errado: texto de exortação e combate. E, para este gênero de teatro, este gênero de interpretação adequava-se perfeitamente.

[...] em Zumbi - e isto não é qualidade nem defeito - cada momento da peça era interpretado "presentemente" e "conflitualmente", ainda que a "montagem" do espetáculo não permitisse esquecer a presença do grupo narrador da história: alguns atores permaneciam no tempo e no espaço dos espectadores, enquanto outros viajavam a outros lugares e épocas.

Resultava daí uma "colcha de retalhos" formada por pequenos fragmentos de muitas peças, documentos, discursos e canções. (BOAL, 2013, p. 175-176)
\end{abstract}

Para Rosenfeld (1982, p. 13), em tal funcionamento, chamado de épico ou narrativo, há pouca distinção entre os personagens para além da máscara comportamental e do caráter típico de um conjunto de pessoas. Através da feitura da totalidade dos personagens e dos conflitos pelo elenco inteiro, intercalados nos papéis, Boal (2013, p. 177) afirma o caminho aberto à segunda técnica, a perspectiva una do grupo narrador, propiciando-se uma interpretação coletiva do acontecimento: "todos os atores agrupavam-se em uma única perspectiva de narradores. O espetáculo deixava de ser realizado segundo o ponto de vista de cada personagem e passava, narrativamente, a ser contado por toda uma equipe, segundo critérios coletivos [...].” (BOAL, 2013, p. 177).

Juntamente com Campos (1988, p. 79-80), é válido dizer que Zumbi, querendo-se "um grande espetáculo épico com bem poucos recursos" - crítica que a pesquisadora traz -, angariado com os itens necessários, é cenicamente inovador, interligado em torno da desvinculação, ou seja, do fato de não haver personagens fixos a atores (a cenografia é minimalista e o elenco usa figurinos homogêneos, visto que a peça se desenrola por meio de narração em conjunto, dispensando-se a diferenciação de papéis pela indumentária ou por ambientes, porquanto esta é dada sobretudo por gestos de comportamento), podendo-se obter "um desempenho épico e um caráter coletivo para a narração" ali proposta, com a expressão social de um grupo e um ponto de vista unificado de interpretação; ainda, como lembrou o programa do espetáculo, essa técnica propiciou a "interpretação coletiva" desejada e foi barata e eficaz para a companhia, mesmo não sendo originalmente sua; por outro lado, como a desvinculação do Arena só mobilizou um pequeno elenco (o qual, apesar do encolhimento, com muita movimentação, conseguiu bons efeitos), ela acarretou a diminuição das particularidades dos personagens e do conflito e, por conseguinte, uma generalização, que podemos relacionar ao já muito comentado maniqueísmo da dualidade da peça, contrapondo 
“oprimidos" cordiais e "opressores" detestáveis; contudo, a esquematização foi simples e teve resultados satisfatórios.

Dando sequência às inovações, Boal (2013, p. 177) explica "a terceira técnica de criação de caos", a combinação de gêneros e estilos diversos em uma mesma peça, algo por vezes julgado como uma arriscada mistura ou como falta de limites, mas, em contrapartida, um aspecto bem acolhido pelo público enquanto rompimento formal significativo:

Dentro do mesmo espetáculo percorria-se o caminho que vai do melodrama mais simplista e telenovelesco à chanchada mais circense e vodevilesca.

[...] Também em estilo, e não apenas em gêneros, instaurou-se o salutar caos estético. Algumas cenas, como a do Banzo, tendiam ao expressionismo, enquanto outras, como a do Padre e da Senhora Dona, eram realistas, a da Ave-Maria simbolista, a do twist beirava o surrealismo etc. (BOAL, 2013, p. 177)

Quanto à qualidade da pluralidade de estilos - que sabemos dirigir-se à atuação -, Campos (1988, p. 81-83) ressalta o aproveitamento de gêneros "do farsesco ao lírico" de Zumbi, em que as cenas foram pensadas separadamente, formando um conjunto de pequenos cosmos; de resto, nisso também reside a distinção entre os dois núcleos de personagens, ficando os gêneros superiores e poéticos direcionados aos escravos, e o baixo cômico, a ironia, a paródia e o prosaico (como dissemos, com mais espaço aparente de fala e diálogo, não intencionalmente) aos brancos - o traço humorístico se situa igualmente no núcleo oposto, só que de forma menor e "pura", não farsesca: a referida especialista ainda afirma que Zambi é claramente trágico, pois pode ser considerado um herói que passa por provação e punição após uma falha (ele confiou no acordo com os brancos e cometeu suicídio por não ver outra saída), fora a existência de suas intervenções poéticas, recheadas de versos, e a presença do coro. Portanto, essa técnica também se liga ao maniqueísmo, tendo sido a diferenciação de gêneros e estilos criticada por ter qualificado epicamente o lado branco e dramaticamente o negro, conforme expusemos durante a peça.

A quarta e última técnica presente em Zumbi é talvez a mais óbvia, o uso da músicapara Rosenfeld (1982, p. 14), adequada em estilos e técnicas saídos do teatro épico -, o que não aproxima propriamente este espetáculo de um musical tradicional, não obstante a experiência breve do diretor com o gênero:

A música tem o poder de, independentemente de conceitos, preparar a plateia a curto prazo, ludicamente, para receber textos simplificados que só poderão ser absorvidos dentro da experiência simultânea razão-música. [...] pela forma simples com que a ideia está exposta, ninguém acreditaria que este "é um tempo de guerra" se não fosse a melodia de Edu Lobo. (BOAL, 2013, p. 177-178) 
De mais a mais, cabe reiterar que muito se falou sobre a comunicabilidade com a plateia que a música pode exercer em um espetáculo, sendo este um dos seus objetivos ao fazer todos entenderem melhor (e comprarem) as ideias passadas através do seu emprego - a sistematização dessa técnica em teatro revelou influência épica, segundo Roux (1991, p. 195196).

Campos (1988, p. 86) faz algumas considerações a respeito da música de Zumbi, aproximando-a do aspecto popular e distanciando-a das "intenções didáticas", pelo fato de, mesmo conduzida por intérpretes não especializados, integrar a plateia pela via do sensível ao espetáculo; no entanto, a pesquisadora se dá conta do caráter didático, o qual a companhia se esforça em exibir também por meio das canções, uma vez que uma postura do público deve ser suscitada - aspecto intimamente relacionado ao feitio épico, como veremos:

O espetáculo quer, sob todas as formas, provocar uma conduta determinada no espectador. Este deve aderir à poética saga dos negros, empunhar a bandeira da continuidade de sua luta e repudiar aquele inimigo, monstruoso pela violência, mas distanciado e relativizado pela força do humor. (CAMPOS, 1988, p. 86)

Com todas as técnicas em mãos e fazendo progredir formalmente o seu grupo, Boal (2013, p. 178-179) diz que Zumbi deveria "sintetizar as duas fases anteriores" à dos musicais, no plano estético: quanto à época do realismo, por exemplo, ele aponta que o dado importante, durante um período, expunha-se a inutilizar uma obra, pois ela se torna dispensável se parecida demais com a realidade empírica reproduzida, havendo pouca margem no naturalismo para o conhecimento e para análises e interpretações mais firmes; contrariamente, na nacionalização dos clássicos, a exclusividade era das ideias (na forma de fábulas e personagens simbólicos), empregando-se elementos a fim de pôr em prática a aproximação do enredo com a contemporaneidade, o que poderia não acontecer facilmente:

Havia que sintetizar: de um lado o singular, de outro o universal. Tínhamos que encontrar o particular típico.

O problema foi em parte resolvido utilizando-se um episódio da história do Brasil, o mito de Zumbi, e procurando-se recheá-lo com dados e fatos recentes, bem conhecidos pela plateia. Exemplo: o discurso de Dom Ayres, ao tomar posse, foi escrito quase que totalmente tomando-se por base recortes de jornais de discursos pronunciados na época da encenação.

A verdadeira síntese, é certo, não se lograva: conseguia-se apenas - e isto já era bastante - justapor "universais" e "singulares", amalgamando-os: de um lado a história mítica com toda a sua estrutura de fábula, intacta; de outro, jornalismo com o aproveitamento dos mais recentes fatos da vida nacional. A junção dos dois níveis era quase simultânea, o que aproximava o texto dos particulares típicos. (BOAL, 2013, p. 179) 
O que se sucederam, como é sabido, foram as correspondências entre o elemento mítico e o momento histórico presente, além de, como um divisor de águas, para Boal (2013, p. 179), Zumbi ter finalizado uma destruição e começado uma renovação formal teatral. Em seu material teórico, o diretor deixou determinadas elucidações sobre o Sistema Coringa ${ }^{13}$, um método pensado em um momento de crise do teatro e em função de demandas estéticas, políticas e sociais por reformulações:

Coringa é o sistema que se pretende propor como forma permanente de se fazer teatro - dramaturgia e encenação. Reúne em si todas as pesquisas anteriores feitas pelo Arena e, nesse sentido, é súmula do já acontecido. E, ao reuni-las, também as coordena, e nesse sentido é o principal salto de todas as suas etapas. (BOAL, 2013, p. 179)

Assim sendo, sabemos da ocorrência de elementos brechtianos (ou épicos), em Zumbi, sobretudo porque o espetáculo, que conta com mais processos de narrativa do que de interpretação dramática, põe em relevo "o efeito de distanciamento" pensado pelo dramaturgo alemão Bertold Brecht, mencionado, por vezes, no exame da peça. Nela, os atores contam a longínqua história de Palmares com a inclusão das analogias referentes ao tempo e à realidade contemporâneos à montagem - aspecto já visto -, logo, destruindo a quarta parede (como alternativamente chamamos a ilusão teatral) para promover a reflexão crítica do público sobre as problemáticas levantadas.

A seguir, não se pretende examinar toda a teoria épica de Brecht (influenciadora da forma e do engajamento do Teatro de Arena), dado que há material de referência que o faz; contudo, achamos necessário repassarmos alguns de seus pontos pertinentes à construção de Zumbi a fim melhor os relacionarmos às indicações incluídas ao longo do presente texto, principalmente na análise da peça discutida.

Considerando o quadro de diferenças entre teatro dramático e teatro épico, percebe-se o desejo de Brecht de desencadear esteticamente a crítica sobre alguma faceta da vida no palco e que esta contagiasse politicamente o público; assim, pelo efeito de distanciamento, a representação distanciaria artisticamente as ações desse público, oferecendo-lhe uma opção

\footnotetext{
${ }^{13}$ Neste trabalho, fora o aparecimento das quatro técnicas experienciadas em Zumbi (a desvinculação de ator e personagem, a perspectiva única, o ecletismo de gênero e estilo e o emprego da música), não aprofundaremos o exame do Sistema Coringa, até porque este ainda não estava presente na referida peça. No entanto, é relevante observar o fato de o método advir das solicitações dos próprios textos teatrais dos musicais (simultâneos ao desenvolvimento do sistema), das carências materiais do Arena, como a precariedade econômica e espacial (isso também diz respeito ao uso de poucos atores), e da urgência em contar e fazer referências ao presente, o que acabou proporcionando as novidades técnicas. Na sequência, Brecht foi praticado junto a Stanislavski, e a empatia foi retomada em Tiradentes, peça que mostrou as funções Protagônica e Coringa. Contudo, há a afirmação de que o emprego do esquema para a montagem de todo e qualquer espetáculo pode ter sido o "pecado" de Boal, pois o seu uso, coerente e original como teoria, na prática, pode se demonstrar negativamente repetitivo.
} 
crítica diante do que vê, antes evitando, igualmente pelo viés artístico, uma atmosfera irreal e a provocação de um "estado de alma", ou melhor, de um transe ou ilusão que retirasse o público do seu lugar real. Como vimos, essa quebra de fantasia (aparência e intenção de realidade) está presente em algumas passagens de Zumbi, mostrando-nos uma atitude dirigida ao espectador para que ele atinja consciência e pense com menos emoção sobre a encenação este é o efeito. No entanto, como a emoção não está anulada, também se manifesta na peça (só não acreditamos que seja possível chegar à catarse, como Campos aponta), justamente por este ser um trabalho que referenciou um momento político delicado e que, ao provocar reflexão sobre isso, desencadeou uma efusão de sentimentos passados do elenco para o espectador, visto ambos serem das mesmas classes sociais e viverem praticamente a mesma realidade.

Retornando à teoria: ao investigar o distanciamento brechtiano, Rosenfeld (1985, p. 155), nota que um olhar com este efeito se aproximaria ao do historiador ("ver em termos históricos"), estimulando o "estado de surpresa" frente ao saber. Para isso, Brecht desenvolveu algumas técnicas (elas dialogam com as de Boal, em algum nível): “Todas elas se ligam à concepção fundamental do teatro épico, isto é, à idéia de introduzir uma estrutura narrativa que, já como tal, implica o 'gestus' da serena e distante objetividade do narrador em face do mundo narrado." (ROSENFELD, 1985, p. 155-156).

Entre os "recursos literários" usados por Brecht em nome do distanciamento, além da narrativa estrutural, Rosenfeld (1985, p. 156-157) destaca a ironia e a paródia, recursos linguísticos, geralmente cômicos e de estranhamento, que pressupõem certa falta de sensibilidade e menos envolvimento daquele que ri (o público não identificado). Como observamos, isso está presente na peça do Arena, marcando o lado branco da guerra.

Quanto a "recursos cênicos e cênico-literários", tem-se: “[...] títulos, cartazes e projeções de textos os quais comentam epicamente a ação e esboçam o pano de fundo social." (ROSENFELD, 1985, p. 158). Esses itens, diz Rosenfeld (1985, p. 158), não fazem propriamente parte da ação a se desenrolar, comentando-a paralela e distanciadamente com o fito de provocar o pensamento. Em Arena Conta Zumbi, há alguns desses elementos, como os slides explicativos dos instrumentos de castigo e a presença dos atores que introduzem o intervalo e o início do segundo ato.

Rosenfeld (1985, p 158-159) ainda realça os lances grotescos em cena e os seus favorecedores, como "o estilo de movimentação", advindo de influências diversas (Meyerhold, teatro asiático e Commedia dell'Arte), e o uso das máscaras "parciais” (motivadas pela última tendência mencionada), que praticamente apenas deformava "as classes superiores" - mais 
um elemento brechtiano relacionável a Zumbi, em que, redizendo, os senhores e soldados foram criticamente ridicularizados por meio de recursos cômicos, usando-se máscaras comportamentais nos atores para isso. No tocante ao cenário, Rosenfeld (1985, p. 159) aponta o fato de este não contribuir para com a ilusão ou a ação, "apenas a comenta", contando-se somente com elementos necessários e podendo-se parodiar a ação - tal como foi feito na simplicidade cenográfica da peça de Boal e Guarnieri -; já a iluminação deve clarear o espaço cênico a fim de proteger o didatismo.

Por sua vez, os "recursos cênico-musicais" fazem "[...] o autor se dirigir ao público através de coros e cantores.” (ROSENFELD, 1985, p. 159). Em Brecht, Rosenfeld (1985, p. 160) salienta que a música também tem o potencial de comentar o texto, posicionar-se frente a ele e lhe aumentar a perspectiva, interrompendo a capacidade de deslumbramento da ação, tendo as canções diversas funções: umas dirigidas para o espectador, com gestus demonstrativo e quebrando a quarta parede; outras para a plateia e demais personagens; umas compõem o contexto e perpassam a ação; outras não têm a ver com a ação, mas promovem uma ruptura de atmosfera e têm o poder de desencadear reflexões. Em Zumbi, há comentário e narração pelo caminho da canção; todavia, pode-se admitir haver paralelamente o envolvimento do público na atmosfera cênica.

Por fim, dizendo que uma atuação "tradicional", na qual o intérprete se identifica com o personagem que faz, anularia os demais métodos na busca do distanciamento, Rosenfeld (1985, p. 161) aborda, sempre à luz do Organon brechtiano, o recurso do "ator como narrador", com quem a sensação de ilusão e empatia do público é eclodida, mas que propõe a identificação (em sua preparação) para chegar ao distanciamento:

\footnotetext{
O ator épico deve "narrar" seu papel, com o "gestus" de quem mostra um personagem, mantendo certa distância dele. Por uma parte da sua existência histriônica - aquela que emprestou ao personagem - insere-se na ação, por outra mantém-se à margem dela. Assim dialoga não só com seus companheiros cênicos e sim também com o público. Não se metamorfoseia por completo ou, melhor, executa um jogo difícil entre a metamorfose e o distanciamento, jogo que pressupõe a metamorfose. Em cada momento deve estar preparado para desdobrar-se em sujeito (narrador) e objeto (narrado), mas também para "entrar" plenamente no papel, obtendo a identificação dramática em que não existe a relativização do objeto (personagem) a partir de um foco subjetivo (ator). (ROSENFELD, 1985, p. 161)
}

Através do argumento da distância, Rosenfeld (1985, p. 162) reforça essa ideia, pois "o ator-narrador", ao emitir uma opinião referente ao personagem e surpreender-se com suas condutas, arroga uma determinada posição de crítica social, exibindo, com esta, dois "horizontes de consciência" (ao mesmo tempo, conglomerados e dissociados, um de quem 
narra e um de quem personifica) - o do primeiro é maior e ele tudo sabe, o do segundo é mais limitado e ele age circunstancialmente, não fatidicamente; contudo, vemos que, para expressar essa "atitude crítica", o ator deve se valer do gesto (corpo e voz), o "gestus social", o qual não precisa corresponder ao texto do personagem, e sim ao contexto social empregado:

\begin{abstract}
A expressão dos personagens é determinada por um "gestus social". "Por gestus social seja entendido um complexo de gestos, de mímica e (...) de enunciados que uma ou mais pessoas dirigem a uma ou mais pessoas". [...] "O gestus social é aquele que nos permite tirar conclusões sobre a situação social". Devem ser elaborados distintamente os traços que se situam no âmbito do poder da sociedade para, em seguida, serem distanciados, recorrendo-se, quando necessário, mesmo a elementos coreográficos e circenses. (ROSENFELD, 1985, p. 163)
\end{abstract}

Tomando como referência os fins políticos e pedagógicos da peça analisada, efetivamente, fica clara a validade das oposições nela propostas, como, por exemplo, bons e maus, negros e brancos, escravos e senhores, etc., algo que, pela circunscrição, poderia ter lhes enfraquecido em cena (o que não aconteceu, tendo em vista o consequente sucesso da realização) e classificado o texto perpetuamente como simplista e maniqueísta, conforme a crítica da época apontou e Boal não negou.

Dessa forma, no período dos musicais, por intermédio de espetáculos ainda não largamente censurados, "sob a forma de protestos políticos", como diria Prado (2009, p. 70), o Arena assimilou (sem usar diretamente) e adequou estilisticamente o teatro épico de Brecht a novas circunstâncias socioeconômicas. As duas peças do "Conta" "[...] tomavam ambas como pretexto a história nacional para evocar rebeliões sufocadas violentamente ou mortas em seu nascedouro - e não por simples coincidência." (PRADO, 2009, p. 70-71). Referindo-se mais especificamente a Zumbi, Prado (2009, p. 71) aparentemente discorda que o maniqueísmo seja um artifício positivo e ressalta o fato de os negros terem apenas qualidades e os brancos somente defeitos, uma vez que o Arena fez da narrativa palmarina (um tanto desconhecida), localizada "entre o real e o lendário", um bom subterfúgio para combater a ditadura e incentivar a resistência:

[...] os negros do quilombo de Palmares têm unicamente virtudes - vigor físico, sexualidade exuberante, apego às mulheres e aos filhos, amor ao trabalho, disciplina guerreira - e os bancos unicamente defeitos: ou são senis, como D. Pedro, ou de comportamento cênico "o mais repugnante possível” (Domingos Jorge Velho), ou "fresquíssimos todos, afetados, artificiais" (os figurantes em geral). Surpreendentemente, é verdade que lançando mão de recursos ignóbeis como a disseminação da varíola, os brancos vencem. Interpretada à luz do que acabara de acontecer no Brasil, a peça queria dizer apenas uma coisa: nós, da esquerda, nós, o povo, nós, os jovens, somos fortes e puros; vocês, os decrépitos, os impotentes da direita reacionária, só ganham mediante a traição e a torpeza. Um desabafo, portanto, 
ingênuo politicamente, equivalente às injúrias trocadas entre inimigos nas antigas batalhas campais. A esquerda, abalada pela derrota, denegria os adversários, com um marcado toque machista, reafirmando a crença em si mesma. (PRADO, 2009, p. 71)

Além do "fervor cênico" que chegava ao público do Arena, Prado (2009, p. 72-73) observa que, sob o influxo do distanciamento brechtiano, o qual já explicamos, a interpretação tornava-se coletiva (ou circunstancial), baseada na máscara social dos personagens (elemento acrescentado a Brecht e desenvolvido no Coringa, a partir da ideia da máscara física), mantendo-se o comportamento com a troca de atores nos papéis, e não na interpretação de um personagem por um só ator, como é sabido - entretanto, o que era utilizado em ensaios por Brecht, a fim de "objetivar a personagem", é uma técnica encenada nos espetáculos do Arena para se enfatizar o viés social.

Diante disso, retomemos as críticas. No geral, Prado (1987) elogia o trabalho, mas faz objeções - como vimos em relação à música. A principal parece ser (justamente) sobre o evidente maniqueísmo, praticado de acordo com as cores de pele dos personagens, idealizando-os, estratégia positiva para o Arena, conforme destacamos:

\begin{abstract}
Os negros têm o alvor dos anjos: constroem um paraíso de pujança econômica, de justiça social, e ainda por cima com deliciosos toques de erotismo. A fórmula perfeita: o trabalho livre e o amor livre. Em compensação, a alma dos brancos é do negror das trevas de Satanás: arrasam, pilham, esfolam, roubam, matam. Os pretos são valentes, fortes, líricos, sensuais. Os brancos são decrépitos, adamados, pernósticos, ridículos. Surpreendentemente, os brancos vencem. Deve haver alguma coisa que não foi bem contada.

É que a peça não se importa muito com a realidade concreta. A idéia que faz dos homens, no que concerne ao bem e ao mal, é essencialmente religiosa: a vida concebida como a luta entre dois princípios opostos, entre os imaculadamente puros e os irremediavelmente perversos. Nesse universo maniqueísta não há lugar para contingências históricas, circunstâncias sociais, toda essa delicada e complexa textura que determina o modo de ser de uma comunidade. Os negros são idealizados como os índios o foram durante o romantismo. No fundo é a visão tradicional da sociedade, mas com os papéis permutados: os que eram considerados bons - os brancos - passam a ser maus e vice-versa. (PRADO, 1987, p. 66-67)
\end{abstract}

Vários elementos são questionáveis nas colocações acima, como, primeiramente, o duvidoso senso comum a respeito da bondade branca e da suposta maldade negra, o que a peça contraria; depois, a liberdade geral, não tão permitida às mulheres, segundo expusemos na análise. Por conseguinte, a crítica mais dura acontece em seguida, sendo endereçada aos autores, os quais, para Prado (1987, p. 67), queriam "contrapor outros mitos aos mitos burgueses", como o da "superioridade" branca, e acabaram se escondendo atrás da demagogia - esta crítica se avizinha ao comentário de João Apolinário, posto a seguir, no tocante aos elementos evidenciados. 


\begin{abstract}
Acreditam que a luta social se faz através de gigantescas simplificações, cuja finalidade é fortalecer o ardor dos combatentes. E é exatamente isso que não nos agrada em Arena conta Zumbi. A esquerda brasileira tem vivido nestes últimos anos num infeliz conúbio com a demagogia, sempre na esperança de surrupiar-lhe as massas eleitorais, mas tendo de se contentar de fato com o papel subalterno e pouco sugestivo de sustentáculo intelectual de um populismo de péssima qualidade. Em vez de servir-se da demagogia em seu próprio proveito, como pretende, ela é que tem servido de retaguarda ideológica à demagogia. (PRADO, 1987, p. 67)
\end{abstract}

Prado (1987, p. 67) ainda aponta o fato de a peça falar de um assunto (a trajetória de Zumbi e de seus ancestrais) que, sozinho, já seria "revolucionário" - a sociedade escravocrata não aceitaria a ventura de Palmares, fosse pelas perdas causadas ou pela ideia da liberdade negra trazida com isso, acarretando a perigosa sugestão da igualdade de raças, começo de um equilíbrio social -; então, conclui-se que a metáfora feita através da história de Zumbi e das lutas dos negros de Palmares por liberdade e igualdade, com a intenção de pintar esse caráter radical, não foi satisfatória, em termos de engajamento, conforme o crítico:

\begin{abstract}
Esse germe de subversão já era suficientemente forte para dispensar qualquer acréscimo caricatural ou reforço romântico. Os grandes temas da democracia liberdade, igualdade, fraternidade, por exemplo - ainda não perderam a sua carga explosiva, podendo ser tratados sem complacência sentimental e também sem picuinhas de consumo imediato, referências cifradas que só são compreendidas por meia dúzia de iniciados políticos. Há uma certa distância entre o "cabaré literário", à maneira alemã, que vive de alusões aos fatos do dia, e a peça de teatro que, mesmo quando engajada, deve pairar a uma altura um pouco mais elevada, tirando daí a sua força de convicção. (PRADO, 1987, p. 67)
\end{abstract}

Já Apolinário (2013, p. 58), em sua crítica, reverencia a obra quanto à elucidação da história e à verdade da interpretação, embora o final do mesmo argumento pareça negativamente crítico, pois os autores “[...] fundamentam arbitrariamente esse complexo confuso e mutável de mito e realidade e oferecem-nos este espetáculo de teatro." (APOLINÁRIO, 2013, p. 58). Logo, a condenação torna-se mais dura, sendo o espetáculo mais positivo do que a peça enquanto texto:

Zumbi, o mito, assume na sua realidade romântica uma pretensão de tese que não resiste à mínima especulação histórica (processo dialético que os autores irreverentemente não utilizam). É óbvio que não apreciaremos essa mensagem de Amor pela Liberdade com uma fundamentação tão frágil, tão superficial e folclórica. [...] Glorifiquemos nossos irmãos negros, a sua e a nossa liberdade, mas não se troquem os valores concretos por abstrações demagógicas, não se confunda o mito com a realidade, nem se distorça um e outra para atingir um populismo que é panfleto, mas não é arte. Fixemos, pois, que, onde se vê e ouve o negro, deve ver-se e ouvir-se o brasileiro. E onde está ou foi branco, é norte-americano. As calças Lee e as execráveis vestes da Ku-Klux-Klan ajudam a criar o atual ambiente que se pretende retratar. A partir daí, o mistério é mais concreto, a verdade menos 
mistificação e todo o resto mais presente, mais conferível, até mais lógico.

[...] Belo espetáculo, não obstante as dúvidas expostas. [...] A originalidade e a força do espetáculo estão em tudo quanto se recria naquele chão: vozes, gestos, cânticos, tudo se plasma para formar essa pequena maravilha que é Arena conta Zumbi, apenas como realização teatral. (APOLINÁRIO, 2013, p. 58; 61)

Por sua vez, a crítica de Yan Michalski a Arena Conta Zumbi, a qual, em outubro de 1965, Michalski (2004, p. 56) diz ser a segunda ao espetáculo “estimulante, simpático e agradável", é rica em elogios sobre o seu talento, apesar de apontar com contundência os seus presumidos equívocos; entre os primeiros, ele ressalta a circunstância de a peça ter sido concebida "fora dos cânones convencionais", não sendo normalmente classificável: "Zumbi é tudo isso, e não é nada disso. É uma tentativa de criar uma fórmula nova; e uma tentativa realizada - pois a fórmula nova, diferente de tudo que já vimos no Brasil, lá está, a desafiar a definição, a catalogação.” (MICHALSKI, 2004, p. 56-57).

A comunicabilidade em relação ao público, muito intensa por parte dos atores - a despeito de incomodar uns e outros espectadores -, também é valorizada por Michalski (2004, p. 57), assim como as qualidades de "talento e bossa", ligadas a isso, de todos os criadores da peça. No entanto, a principal falha de Zumbi é apontada: “O defeito do espetáculo consiste no fato de que ele acaba confundindo os meios com os fins e mostrando simplesmente a força e a vibração da juventude, mais do que transmitindo alguma coisa através da força e da vibração da juventude.” (MICHALSKI, 2004, p. 57).

Após ressaltar a satisfação de assistir à junção festiva proporcionada, Michalski (2004, p. 57-58) passa a destacar determinados problemas de compreensão de determinados dados da peça (advindos de sua visão pessoal como espectador), algo abrandado na temporada dirigida por Paulo José, ao preço de se reduzir a força dinâmica do conjunto:

A cabeça é que não fica tão bem aquinhoada. O espectador sai do teatro encantado e confuso. Sabe, confusamente, que a história à qual assistiu é a história da luta dos negros pela liberdade, mas as sutilezas e os detalhes dessa luta não ficam lá muito claros no seu espírito. É verdade que já a proliferação dos nomes africanos contribui para essa falta de clareza: o espectador acaba criando uma certa confusão em torno de Zambi, Zumbi, Ganga Zumba, Ganga Zona, Gongoba etc., ainda mais em virtude do recurso empregado que consiste em fazer interpretar o mesmo personagem sucessivamente por diversos atores do elenco. Mas o grande fator responsável pela pouca clareza do espetáculo é, paradoxalmente, a qualidade e a comunicabilidade dos seus meios expressivos. Os autores não previram, obviamente, o efeito de alienação produzido pela esplêndida música e pela ótima mise-en-scène, em função das quais conceberam o seu espetáculo. [...] É possível que, se o texto fosse menos fragmentado, mais equilibrado e menos apressado, ele resistiria melhor à concorrência da música e da movimentação; mas vale a pena lembrar que mesmo Brecht, que deu à música um destaque tão grande nas suas peças, dosava o uso dessa música com economia e adotava o texto cantado apenas para resumir e comentar o conteúdo das cenas recitadas, e não para substituí-las, como acontece em Zumbi. (MICHALSKI, 2004, p. 57-58) 
Outra observação feita por Michalski (2004, p. 58) refere-se à inutilidade dos "recursos fáceis e baratos" presentes na peça, de certa forma incompatíveis com a sua boa execução - como sabemos, Zumbi tinha a intenção de promover conexões entre a luta quilombola por liberdade e outros conflitos libertários, principalmente aquele que se pensava ocorrer durante a ditadura brasileira; porém, essas associações eram bem claras por si só, então, o crítico parece indicar que tais artifícios acabavam subestimando a capacidade de assimilação do público: “Teríamos compreendido a mesma coisa vendo apenas a luta dos negros pela liberdade, sem que fosse necessário oferecer-nos facilidades de gosto duvidoso, tais como a exploração da palavra subversivo, ou o perigo da infiltração negra, por exemplo." (MICHALSKI, 2004, p. 58-59).

Sábato Magaldi foi outro crítico do espetáculo. Em seu livro sobre a história do Teatro de Arena, encontramos muitos elogios e confirmações para argumentos já teorizados:

\footnotetext{
Impressionou-me a violência da montagem. Nada houve entre nós, até aquele momento, que significasse uma condenação tão radical da ditadura instalada pelos militares. Todos os aspectos do golpe são analisados, sem que se poupe um. Política exterior, subserviência aos Estados Unidos, as "marchadeiras", a aliança EstadoExército-Religião, o moralismo pequeno-burguês, a aliança com a corrupção (o exgovernador Ademar de Barros) para combate ao comunismo - tudo é meticulosamente composto, a fim de estimular o espectador no propósito de protesto. A narrativa flui com espontaneidade e inteligência, e as alusões são claramente apreensíveis.

Não há dúvida de que a direção de Augusto Boal enfatizou a caricatura dos brancos, inclusive com meneios adamados nas reuniões palacianas, reservando para os negros apenas os gestos belos e heróicos. Mas tratava-se de enaltecer a resistência de um povo que fugia da escravidão, construindo, em diversos mocambos reunidos no quilombo de Palmares, uma vida semelhante à das aldeias africanas, de onde a cupidez branca os sequestrou. E, por meio da valorização dos oprimidos, Zumbi verberava os que, pela força, empolgaram o poder.

[...] A ação se desenvolve por meio de flashes, em que surgem apenas as personagens necessárias ao progresso da história.

[...] Com essa técnica, não poderia haver aprofundamento de caracteres, mas apenas uma ilustração sumária de fatos que, ao longo de várias décadas, marcaram uma realidade incômoda na História do Brasil. Não houve, também, o intento de reconstituir o sucedido, privilegiando-se as cenas imaginárias que poderiam conotar uma situação semelhante do presente. $\mathrm{O}$ maniqueísmo era, antes, uma forma de aludir pejorativamente ao regime que se substituíra à nossa frágil democracia. (MAGALDI, 1984, p. 67-70)
}

Ademais, em uma tentativa de aproximação do engajamento do Teatro de Arena com os argumentos dos teóricos do conceito, anteriormente visitados nesta dissertação, pode-se concluir que o grupo se torna engajado e sartriano principalmente no que tange à relação com o seu público, já apontada, no sentido de apelar à liberdade deste para receber auxílio na construção da obra exposta - ou seja, compartilham-se noções adquiridas com o espectador, 
que as mantém em sua bagagem. É interessante frisar, também, o fato de as peças "metafóricas" do teatro de Guarnieri serem posteriores aos musicais; assim, a semente cultivada por elas nos anos de maior repressão já estava plantada nessa intenção primeira de fazer alusão ao momento político no qual a liberdade nos faltava, devendo tal ausência ser ultrapassada pela arte. Ainda, no tocante aos teóricos e no que concerne a Zumbi, poderíamos julgar acertada a afirmação bentleyana de que uma peça de "desnudamento" de uma situação ou figura importante só chega ao seu objetivo exatamente pelo fato de ser uma dramatização, de ser teatro - uma arte presente e em contato direto com o seu destinatário, no qual provoca imediatamente os seus efeitos. Reiteremos: no caso, aquilo que o Arena mais ambicionava proporcionar era a compreensão (já filtrada pelo seu crivo interpretativo) do período históricopolítico pela plateia, composta por gente que partilhava de suas posições de esquerda, a fim de responder à ditadura. Por fim, concordando com Adorno (1973), sabemos que não há literatura alguma sustentada apenas pelo conteúdo, então, é possível observar a importância da forma em Arena Conta Zumbi (peça que procurou inovar formalmente, igualmente trazendo elementos de formas antigas), algo que a crítica não se preocupou em ver: como dissemos, porquanto Boal defendia que a arte engajada, para falar às massas, teria de se fazer entender, o seu esquematismo maniqueísta indica ser uma simplificação com esse fim. Nesse caminho, há uma pesquisa formal sendo encaminhada pelo grupo (que chega, logo mais, ao Sistema Coringa e à validação do teatro épico), valorizando o trabalho e não fazendo da obra um resultado sem um objetivo mais alto, de pesquisa e relação dialética com o passado.

De acordo com o posicionamento adotado no capítulo inicial deste trabalho em relação ao conceito de engajamento, acreditamos que a simples razão de o Teatro de Arena ter escolhido criar Arena Conta Zumbi tal como ela é, no contexto do pós-golpe de 1964, revela o desejo coletivo de esclarecer, mostrar, didatizar e promover a reflexão (mais do que o encantamento) sobre o momento e a realidade das pessoas, nisso também residindo o engajamento mais politizado do grupo. Conforme vimos, este foi em busca do povo, durante a sua história, primeiramente informando e passando mensagens; depois, dando-se conta de que o povo brasileiro precisava ter e fazer o seu teatro. Desse modo, antes de fomentar o chamado Teatro do Oprimido, ao que Boal chegou após o trabalho no Arena, conjuntamente, a companhia quis contar algo sobre aquele instante específico de 1965, fazendo referência crítica ao presente amargo (e ainda tateando-o) através do passado, querendo trabalhar politicamente o período vivenciado. Portanto, isso é ser engajado, mantendo-se ou não o foco no dado político, mas objetivando-se a consciência social do público de cidadãos ativos.

A título de fechamento da atual seção, é interessante agregarmos o comentário de 
Roberto Schwarz (1978) sobre o espetáculo estudado e o contexto de seu surgimento, ratificando muito do que dissemos no primeiro capítulo e trazendo a sua experiência sobre o momento. Schwarz (1978, p. 79) diz que "o processo cultural” do pré-64, o qual não vinha se limitando a classes e mercados, foi descaracterizado depois do golpe, quando as formas artísticas, então pensadas para os oprimidos, a quem não se chegava, acabaram oferecendo-se à pequena burguesia (estudantil e artística) e transformando-se em mercadoria, ou melhor, em "símbolo vendável da revolução", formando uma cadeia para a arte engajada - diante do que podemos aludir às contradições do teatro político:

\begin{abstract}
As formas políticas, a sua atitude mais grossa, engraçada e didática, cheias do óbvio materialista que antes fora de máu-tom, transformavam-se em símbolo moral da política, e era este o seu conteúdo forte. O gesto didático, apesar de muitas vezes simplório e não ensinando nada além do evidente à sua platéia culta - que existia imperialismo, que a justiça é de classe - vibrava como exemplo, valorizava o que à cultura confinada não era permitido: o contato político com o povo. Formava-se assim um comércio ambíguo, que de um lado vendia indulgências afetivo-políticas à classe média, mas do outro consolidava a atmosfera ideológica [...]. (SCHWARZ, 1978, p. 79-80)
\end{abstract}

Particularmente, o pesquisador deixa antever que a problemática da hegemonia, dita algumas linhas antes, não é real, mas relativa: o universo da esquerda foi modificado e acabou, no limite, ajudando a estabilizar a ideologia do capital. Entretanto, esse trajeto não foi direto: após o entusiasmo de 1964, certos artistas ficaram receosos perante a presença do protesto na arte, fazendo novas avaliações diante da situação. Dessa forma, conclui-se que as preocupações da esquerda artística na era ditatorial pré-AI-5 diferenciam-se e vão se modificando, isto é, apesar da hegemonia, não é "tudo a mesma coisa": num primeiro momento, com relação ao regime, reage-se ao capitalismo e ao golpe, ali entrelaçados; já ao final da década, o horizonte cultural é mais propriamente mercadológico (um "mal necessário"), fazendo com que as preocupações também se alterem, pois o mercado não tinha sido visto como algo necessariamente ruim para a arte politizada - por exemplo, antes, para sobreviver, o Arena quis se profissionalizar cada vez mais, ao passo que o Centro Popular de Cultura colocou-se do outro lado, correndo os riscos da escassez de apoio ao teatro de esquerda como um todo. Posteriormente, no entanto, a questão da "arte a ser vendida" foi criticada pela esquerda e, além de ter sido colocada no debate de Roda Viva, adesões descaradas ao mercado fossem eventualmente condenadas.

Para Schwarz (1978, p. 80), a aparente "repetição de argumentos" do nosso teatro imediatamente pós-golpe civil-militar, na verdade, indicava resistência e permanência de crenças, sugerindo um caminho aberto; assim, operários não frequentavam teatros, mas havia, 
entre os artistas e o público, de grande maioria esquerdista, um reconhecimento (ou vontade disso) em direção ao povo, fora a ampla pregação contra o regime, o capitalismo e o imperialismo norte-americano: "Daí a importância dos gêneros públicos, de teatro, afiches, música popular, cinema e jornalismo, que transformavam este clima em comício e festa, enquanto a literatura propriamente saía do primeiro plano.” (SCHWARZ, 1978, p. 80).

Como exemplo das anomalias dessa cultura ávida por revolução, com suas vantagens e desvantagens, Schwarz (1978, p. 80) menciona alguns espetáculos teatrais de protesto, encadeados entre si, desse período: "A primeira resposta do teatro ao golpe foi musical, o que já era um achado." (SCHWARZ, 1978, p. 80). Nisso, o Show Opinião (dirigido por Boal, do Arena, "o grupo que mais metódica e prontamente se reformulou") e Liberdade, liberdade, ambos do Grupo Opinião, uniam música e povo brasileiro para combater a ditadura: “Apesar do tom quase cívico destes dois espetáculos, de conclamação e encorajamento, era inevitável um certo mal-estar estético e político diante do total acordo que se produzia entre palco e platéia." (SCHWARZ, 1978, p. 80). Essa excitação geral, logo após o golpe sobre a esquerda, erroneamente demonstra, conforme Schwarz (1978, p. 80-81), uma ausência crítica quanto ao populismo, à consciência e às responsabilidades do fracasso, ainda neste momento, o que vai constituir o "limite estético" do Arena; sobre esse tempo, o ensaio igualmente ressalta que a recepção dos espetáculos começava a contar com numerosos estudantes na plateia, obtendo-se um público "mais politizado e inteligente" (predominante no panorama geral do teatro de vanguarda), portanto: "Em consequência aumentou o fundo comum de cultura entre palco e espectadores, o que permitia alusividade e agilidade, principalmente em política, antes desconhecidas.” (SCHWARZ, 1978, p. 81). As peças políticas, garantindo essa cumplicidade, segundo Schwarz (1978, p. 81), proporcionariam um ambiente favorável ao engajamento, ao "argumento ativo, livre de literatice", modificando-se também o "lugar social do palco".

Tendo em vista a repressão propagada pelos direitistas à "revolução brechtiana", Schwarz (1978, p. 81-82) dá relevância ao público estudantil e a seu movimento, a quem a arte achegava-se (desaguando na formação da "vanguarda política do país"): "Esta combinação entre a cena 'rebaixada' e um público ativista deu momentos teatrais extraordinários, e repunha na ordem do dia as questões do didatismo." (SCHWARZ, 1978, p. 81); já quanto à pertinência das ideias deste, pensando na sua forma, o texto traz à tona algumas considerações a respeito da democratização artística, defendendo tratar-se isso de "transformações sociais e de critério" das quais Brecht era um exemplo - o dramaturgo orientava os atores para a pesquisa de gestos a fim de melhor "devolvê-los ao povo", este enquanto público e origem, estando os gestos presentes na arte e na vida real (conciliadas). $\mathrm{O}$ 
Arena era engajado nessas ideias:

O que é bom na vida aviva o palco, e vice-versa. Ora, se a forma artística deixa de
ser o nervo exclusivo do conjunto, é que ela aceita os efeitos da estrutura social (ou
de um movimento) - a que não mais se opõe no essencial - como equivalentes aos
seus. Em consequência há distensão formal, e a obra entra em acordo com o seu
público; poderia diverti-lo e educá-lo, em lugar de desmenti-lo todo o tempo. Estas
especulações, que derivam do idílio que Brecht imaginara para o teatro socialista na
R. D. A., dão uma idéia do que se passava no Teatro de Arena, - onde a conciliação
era viabilizada pelo movimento estudantil ascendente. A pesquisa do que seja
atraente, vigoroso e divertido, ou desprezível - para uso da nova geração - fez a
simpatia extraordinária dos espetáculos do Arena desta fase. (SCHWARZ, 1978, p.
82)

Entre matéria representada e forma, o sociólogo mapeia estética e politicamente o Teatro de Arena e dois de seus musicais, Arena Conta Zumbi e Arena Conta Tiradentes, beneficiários desse público e clima. Quanto ao primeiro sucesso, foco deste estudo, Schwarz (1978, p. 82) diz que o enredo histórico adotado tratava de "uma fuga e rebelião de escravos", através de práticas compreensíveis e atrativas à recepção, além da inovadora interpretação coletiva, com aproveitamento de gestos - como foi dito, usando-se a luta contra a escravidão para aproximar as lutas populares e o público. Em sua conexão com este, Schwarz (1978, p. 82-83) conta que o Arena parecia reprisar Opinião (tinha-se música e povo contra a ditadura), não havendo crítica ao malogro esquerdista, do qual também participou:

À oposição entre escravos e senhores portugueses, exposta em cena, correspondia
outra, constantemente aludida, entre o povo brasileiro e a ditadura pró-imperialista.
Este truque expositivo, que tem a sua graça própria, pois permite falar em público do
que é proibido, combinava um antagonismo que hoje é apenas moral - a questão
escrava - a um antagonismo político, e capitalizava para o segundo o entusiasmo
descontraído que resulta do primeiro. Mais precisamente, o movimento ia nos dois
sentidos, que têm valor desigual. Uma vez, a revolta escrava era referida à ditadura;
de outra, a ditadura era reencontrada na repressão àquela. (SCHWARZ, 1978, p. 83)

Primeiro, há a destreza do pretexto de se falar do presente, e aí Schwarz (1978, p. 83) demarca, entre outras coisas, a precipitação na adaptação do "material histórico", com os anacronismos postos a nu, como se fossem "uma virtude estética" que mostra o modo e o tema a ser discutido; depois, o enfrentamento de escravos e senhores corresponderia ao conflito entre povo e imperialismo; assim, dissipam-se "as distinções históricas" e cai-se no "lugar-comum", referente ao "direito dos oprimidos" e à "crueldade dos opressores", na conhecida perseguição pela liberdade: "Ora, o vago de tal perspectiva pesa sobre a linguagem, cênica e verbal, que resulta sem nervo político, orientada pela reação imediata e humanitária (não-política portanto) diante do sofrimento.” (SCHWARZ, 1978, p. 83). 
Enfatizando criticamente a junção de Brecht e Stanislavski, Schwarz (1978, p. 83-84) ainda discorre a respeito de Arena Conta Tiradentes, espetáculo fora de nossa alçada, mas que também fez Boal encarar a "dualidade" referida, já com a renovação concluída. Vimos indicada em Tiradentes a existência de um pensamento crítico por parte da plateia, convergindo com um "distanciamento" brechtiano, igualmente havendo, por outro lado, uma "identificação" naturalista stanislavskiana, porque, para Boal, o teatro deveria tanto "criticar como entusiasmar": "A oposição entre os dois, que na polêmica brechtiana tivera significado histórico e marcava a linha entre ideologia e teatro válido, é reduzida a uma questão de oportunidade dos estilos." (SCHWARZ, 1978, p. 83-84).

Nesse momento pós-golpe, considerando o teatro brasileiro mais proeminente, pode-se dizer que as diferenças entre Teatro e Arena e Teatro Oficina começaram a transparecer principalmente ao final da década de 1960, quando este último tendeu mais à linha considerada irracional, conforme examinaremos no capítulo seguinte. A propósito, há entrevistas dos líderes de Arena e de Oficina, respectivamente Augusto Boal e José Celso Martinez Corrêa, na ocasião dos fechamentos de seus teatros - tendo em vista os anos de diferença de um para o outro -, nas quais fica evidente a ruptura ocorrida no teatro político por volta de 1968. Inclusive, sabemos da objeção de Boal a Zé Celso e ao antigo CPC, consubstanciada na organização da I Feira Paulista de Opinião, espetáculo de união da classe artística da qual Zé Celso também participou, em uma época em que a tônica adotada era a de radicalizar os meios artísticos e desobedecer à censura. Assim, no geral, o desafio do teatro do período foi ser criativo e crítico da realidade brasileira frente à crescente opressão.

Portanto, usando recursos descobertos nas fases anteriores e tendo como referência uma história custosa a seus membros, o Teatro de Arena propôs Arena Conta Zumbi. Neste espetáculo original, o escravo toma a frente para representar, por alusão, a plateia de classe média, em sua maioria (diferente do povo "buscado" incansavelmente antes disso), que, dentro e fora do teatro, ajudou a companhia a formar a possível frente ao golpe. Com este desígnio, Roux (1991, p. 196) confirma o fato de o Arena ter definido como estória a ser contada a saga colonial que expôs algumas ranhuras da ditadura cívico-militar, então em voga, com coerência tal para engajar também a recepção diante deste episódio da nossa história política - em suas bases, o regime contava com o reforço do imperialismo americano, do reacionarismo da burguesia, da relação entre a Igreja Católica e o poder corrupto do Estado, do esfacelamento do comunismo e da desigualdade acarretada pelo capitalismo, entre outros fatores elencados durante a análise.

A partir do que foi visto neste capítulo, é pouco relevante sentenciarmos as 
declarações críticas expostas sobre a peça, a saber: se ela versa sobre o momento pré-golpe e as mancomunações e planos precedentes, ou sobre o desmantelamento da resistência após o estabelecimento do regime, ou ainda, se as analogias anacrônicas são ruins, pois sabemos não ter havido resistência efetiva em 1964. É mais interessante observar que o Arena sempre quis fazer parte de um movimento engajado em arte, em vida e em política, em favor do povo e em prol das linguagens brasileiras (sobretudo com obras próprias). Para isso, trabalhou progressivamente, exercitando um engajamento talvez mais diretamente politizado através dos musicais, nos quais se posicionou de acordo com a época, e por meio da Feira, afrontando as temidas consequências do autoritarismo. Com uma arte social e politicamente empenhada, uma forte intenção didática e a exaltação patriótica evidente, o grupo realizou um trabalho teórico admirável e teve como plataforma radical o oferecimento de peças nacionais - a maioria escrita pelos próprios membros -, apesar de também ter apresentado obras estrangeiras em tom nacionalizante. Levando isso em conta, pode-se concluir que o Teatro de Arena associa, então, sentidos mais amplos de engajamento (como foi delineado no primeiro capítulo), em favor das funções da arte, de militância, vista especialmente como partidária, e de teatro político, preocupado em discutir aspectos sociais, sendo quase impossível não o considerar engajado. Por fim, é notável que, embora a companhia tenha renovado a forma teatral, o ponto de partida da arte engajada aqui teria mais a ver com o seu conteúdo, algo que paradoxalmente poderia restringir o alcance da montagem - a política parece ter protagonizado e a estética figurado, no engajamento do período abordado -, o que não se confirmou, dada a eficácia dos projetos. 


\section{E EIS QUE CHEGA A RODA VIVA “OFICINEIRA"}

\subsection{As várias rodas}

A trajetória do Teatro Oficina não foi construída de maneira linear, tal como a do Teatro de Arena (em que uma coisa levou à outra, para ordenar as fases de trabalho), havendo muitas revisões de método e estilo, bem como debates entre seus componentes, sem contar algumas crises (pessoais e sociais), pausas entre projetos e abandono de atividades importantes nomes da companhia, como Fernando Peixoto, Renato Borghi e Ítala Nandi chegaram com o tempo, sem estarem presentes na fundação do grupo, e também se despediram dele durante a sua história de debates e ideias irreconciliáveis. Assim sendo, o atual capítulo se diferenciará do anterior em função dessas ambiguidades: alguns momentos dessa história de autobusca (que possam ter influenciado o porvir) serão levantados até chegarmos em 1968, ano relevante para o exame do trabalho de José Celso Martinez Corrêa em Roda Viva, de Chico Buarque, no qual o reflexo crítico da classe média foi posto a nu. Tal tarefa será cumprida considerando, principalmente, Peixoto (1982), Corrêa (1981) e determinados textos presentes em Martinez Corrêa (1998), além de outros materiais por vezes indicados.

Primeiramente, é importante saber que a Cia de Teatro Oficina nasceu, de forma despretensiosa e amadora, dentro da Faculdade de Direito do Largo de São Francisco, no ano de 1958, formada por alguns alunos de classe média com interesses comuns e horas diárias juntos (Zé Celso, Borghi, Carlos Queiroz Telles e Amir Haddad fizeram parte da sua criação) - os intelectuais não eram diretamente envolvidos com o Centro Acadêmico XI de Agosto, de lutas políticas. O nome Oficina e o símbolo da bigorna advieram das ideias de trabalho e de exercício contínuos (de se conhecer e se libertar): acatando uma visão trabalhista (a mais correta moralmente, na época), a intenção era associar a atividade teatral a qualquer outra, vendo o ator como um operário e não mais alguém com uma vocação ou dom abstrato e sagrado. Como o universo desses jovens era mais ou menos o mesmo, as temáticas iniciais versavam principal e frequentemente sobre as problemáticas da família de classe média brasileira, meio de origem dos fundadores do grupo e da plateia habitual. Ainda relativamente aos inícios no amadorismo, após A ponte e Vento forte para papagaio subir, pode-se dizer que a peça $A$ Incubadeira, de Zé Celso enquanto autor (ele começou como dramaturgo), foi o primeiro sucesso, inclusive financeiro, do Oficina, com foco no plano individual, em tempos de libertação da família. Herdeiros de Arena e Teatro Brasileiro de Comédia (TBC) - em 
termos de preocupações histórico-sociais e ideologias políticas inclinadas para a esquerda, depois, em motivações estéticas e agregação de outras culturas, respectivamente, apesar de se contraporem ao último pela produção europeizada -, entretanto, sem possuir uma sede própria e estabilidades, no máximo tendo vencido um concurso na TV, eles faziam "Teatro a Domicílio", apresentavam-se em night clubs, estreavam em outros teatros (inclusive no Arena) e ensaiavam em um prédio chamado Quitanda, localizado perto do lugar onde veio a estrear e se estabelecer permanentemente a companhia, na rua Jaceguai, no bairro do Bexiga. Nesse tempo, o Oficina já alugava o Teatro Novos comediantes, instalado neste endereço, que antes havia abrigado um teatro espírita.

Quanto às aproximações com o Teatro de Arena, ícone de renovação dramatúrgica, essas não foram raras e começaram logo em 1959, já com um olhar de interesse do pequeno grupo, que angariava sucesso e prêmios, ao profissionalismo e a fusões. Com a descoberta do existencialismo (provedor de liberdade e indagações), em 1960, portanto, pode-se marcar o fim do amadorismo da companhia e o começo das elucidações de sua personalidade diversa e incoerente, havendo as montagens de Fogo Frio, de Benedito Ruy Barbosa, dirigida por Augusto Boal, do Arena, e de A Engrenagem, de Jean-Paul Sartre (de quem já haviam montado As moscas), adaptada do cinema pelo mesmo diretor junto a Zé Celso, seu assistente de direção. Além do crescimento da qualidade, este foi também o trabalho que despertou ações proibitivas e marcou o primeiro embate do Oficina com a censura, dando origem a um ato no Museu do Ipiranga, talvez pelo tom mais político-social escorrido do Arena ao Oficina. Boal chegou a contribuir na formação dos atores do grupo menor, repassando seus conhecimentos estruturais de Constantin Stanislavski em laboratórios e aprofundando-os no realismo: queria-se romper com a interpretação europeia e imperativa legada pelo TBC com uma atuação mais crítica, fazendo um cruzamento com o existencialismo e uso do corpo do ator.

Após tal sequência, as questões de profissionalismo e autonomia e os problemas que os acompanham estavam muito em voga nos debates da companhia e do teatro paulista como um todo, sendo uma das crises sobre o seu futuro exposta em 1961. No mesmo ano, porém, após arrecadações e muito trabalho, a empresa profissional Companhia Teatro Oficina Ltda. inaugurou o prédio alugado renovado e com um palco sanduíche, montando A Vida Impressa em Dólar, de Clifford Odetts, que, depois de severas interdições imediatas, até mesmo do edifício teatral, fez sucesso, abrindo espaço para o debate entre teatro comercial e cultural. Além disso, é notável, por esse tempo, o aumento das preocupações sociais do grupo, embora os fatos principais do período estilisticamente indefinido sejam a admissão de Zé Celso 
enquanto diretor, começando uma escrita cênica criativa e visual, e o início do ciclo de peças americanas utilizadas para pensar a realidade brasileira, impulsionado por Stanislavski e resgatado pelo Oficina em alguns de seus espetáculos posteriores. Todavia, isso não impediu a montagem de uma comédia de Boal, José do Parto à Sepultura, em mais uma aproximação com o Arena. Ainda, o diretor carioca realizou a montagem "oficineira" de Um Bonde Chamado Desejo, de Tennessee Williams, no ano seguinte, $1962^{14}$. Claramente, nessa época, começou a ser desenhado um quadro de vigências concomitantes até a década seguinte: em São Paulo, o Oficina renovava a encenação, e o Arena a dramaturgia brasileira; porém, as radicalizações de um e outro foram distintas, a respeito da transformação social ${ }^{15}$. Apesar dos contatos frequentes, Zé Celso, classificado como pequeno-burguês, chegou a ser escamoteado pelos companheiros de Boal; portanto, suas visões eram divergentes e acabaram se chocando: tido como psicológico e emocional, mas para si mesmo sendo criativo e aspirante a outras classes, o Oficina considerava que o Arena (à exceção de Boal, o mais crítico, humorado e racional do grupo) estereotipava o conceito de popular e padronizava a interpretação de forma paternalista e católica - com um realismo no qual o povo sempre era bom e sofredor, antevisto em Black-tie, falava-se sobre o povo sem pertencer nem se dirigir a ele como público. Considerando isso, adiantemos a discussão final, através da visão dialética de um dos artistas:

\begin{abstract}
Mas Oficina e Arena me parecem uma unidade. [...] Cada vez mais tenho a certeza que, em conflito, se completam. Não apenas porque o Oficina deu seus primeiros passos praticamente dentro do Arena, mas também porque resultou na concretização de uma alternativa irrecusável em determinado período da sociedade brasileira. Não só porque muitos atores ou encenadores ou cenógrafos passaram de um grupo para o outro ou chegaram até mesmo a pertencer aos dois.

[...] Mas certamente os dois ocuparam papéis de modelo e conseqüente hegemonia. É evidente que não tem sentido cair na armadilha redutora da comparação de qualidade ou importância. Oficina e Arena foram duas faces da mesma moeda. Diferenças e divergências nunca impediram um trabalho integrado e em muitos aspectos unitário. Diversidade de composição interna e de projeto de trabalho nunca
\end{abstract}

\footnotetext{
${ }^{14}$ Vendo-se já como empenhado e libertário, o Oficina investigava a renovação da arte e, assistindo ao aprisionamento público do projeto social e nacionalista do Arena, repensou o seu lugar nesse desenvolvimento, sem ignorar os questionamentos filosóficos e políticos, presentes na referida peça.

${ }^{15}$ Entre 1966 e 1967, tivemos um momento em que as cisões se acentuaram; assim sendo, consideramos ter havido no mínimo três correntes à esquerda, desenhadas até a chegada de um confronto artístico mais aberto em 1968, muito em função dos desdobramentos do golpe e da falta de resistência efetiva a este: a Frente Ampla/Legalidade (oposição comportada), a luta armada (esquerda inconformada) e o desbunde. Ligado a isso, temos a ideia de continuidade entre Arena e Oficina, dividindo opiniões: Fernando Peixoto e Roberto Schwarz afirmavam os laços de complementaridade e ambiguidade, respectivamente, entre os grupos; também, para Costa (2016, p. 150-152), após uma companhia esquerdista como o Teatro de Arena ter negado seus feitos anteriores a 1964, radicalizando-se, era esperado que outros grupos teatrais, como o Oficina, até então desconectados disso, fossem "os continuadores críticos dessa luta" - essa foi a sensação até mesmo de membros do Arena, embora não fosse a crença de Boal e Guarnieri, ainda que comumente se acredite no Oficina como "a vanguarda do teatro revolucionário no Brasil", a partir de $O$ Rei da Vela.
} 
se transformaram em contradições verdadeiramente antagônicas: enquanto teoria e prática esta complexa articulação contraditória (que não existia apenas entre um grupo e outro, mas também no interior de cada um) encerra um trabalho políticocultural de extrema riqueza e significado, espelho de uma questão ideológica difícil que, em outro tipo de reflexão, precisaria ser hoje retomada. (PEIXOTO, 1982, p. $11-12)$

Tendo em vista os novos estudos internos do Oficina, em 1962, os chamados "ciclos" de Araraquara (dos primeiros textos, de autoria própria) e americano (pelo qual se gerou a atração de discutir a realidade ligada ao sistema familiar-social) se fecharam de vez para dar lugar a textos russos montados pela companhia. Nisso, frente a uma das tantas crises e da tentativa de repetição exitosa com Todo Anjo é Terrível (Look Homeward, Angel), de Ketti Frings, o espetáculo Quatro num Quarto, com dramaturgia de Valentim Katáiev, salvou o orçamento do grupo, tanto que, até mesmo uma alternância de elencos foi possibilitada, após o recebimento de um prêmio do Sindicato dos Jornalistas. Ademais, o interesse por Pequenos Burgueses, de Máximo Gorki, ganhou relevo em meio a trabalhos não realizados e originou a tradução própria (de Zé e Peixoto) e mais uma futura estreia; entretanto, o sucesso da montagem stanislavskiana só veio após alguns altos e baixos. Por sua vez, em 1963, é relevante destacar a existência do Concurso de Peças e do Curso de Interpretação, dado no Oficina por Eugênio Kusnet, este, apesar das divergências, um diretor de extrema importância para a companhia, principalmente no tocante aos estudos de Stanislavski - contrário ao emocionalismo dos laboratórios, em seu papel formativo, ele legou racionalidade. O Oficina já desenvolvia trabalhos dentro do estilo realista (inclusive, havia feito um curso de interpretação com o diretor e o trabalho com Boal), mas Kusnet sistematizou tal uso, unindo-o ao aproveitamento de Bertold Brecht e fomentando uma interpretação adversa à do TBC ou da Escola de Arte Dramática (EAD), onde o ator seguia os mandos do diretor. O resultado disso foi Aconteceu em Irkutsk, de Alexei Arbnsóv, realizado com alunos dois anos depois, o único espetáculo do "Studio Um” do Oficina.

Conforme é sabido, os períodos pré e pós-golpe civil-militar, ocorrido em 1964, foram de muitas tensões na arte cênica, sobretudo naquela vinculada à nossa realidade social (politicamente falando da classe média), como era o caso de Pequenos Burgueses: a peça entrou em cartaz em 30 de março do ano anterior e foi suspensa em 3 de abril de 1964, sendo seguida por viagens forçadas e modificações dos membros do grupo, mas voltando à temporada no começo de julho do mesmo ano, por meio de pagamentos à polícia e sem a Internacional na trilha. Este espetáculo e Quatro num Quarto foram remontados durante a evolução do Oficina, pois traziam fôlego à trajetória de crises financeiras e revisionais do 
conjunto. Portanto, além de ter feito um enorme sucesso e dizer respeito às próprias realidade e classe social dos artistas (trazendo o trabalho para si) e do público teatral sessentista, já o confrontando criticamente, Pequenos Burgueses mostrou o herói popular, os problemas sociais em torno da companhia e a sua maturidade (com a volta do autoconhecimento), expondo aprofundamento cênico e político nos trabalhos passados e, ao mesmo tempo, emoção e racionalização, contando, nas definições da prática, com elementos de Stanislavski, mas, também, cada vez mais com tópicos brechtianos - algo que veio a crescer na linguagem "oficineira" no esgotamento da corrente anterior.

Fora os percalços com a interrupção de uma peça mais política e estabilizadora (a qual angariou sucesso, prêmios e viagens), o golpe de 1964 trouxe, no lugar da ensaiada Pena que ela seja uma puta, de John Ford, a estreia de Toda Donzela Tem um Pai que É Uma Fera, comédia com texto de Gláucio Gil, de abordagem mais branda, se comparada à de Pequenos Burgueses, visto que o objetivo do Oficina era somente o de não fechar totalmente as portas. Logo, naquele ano, eles conseguiram manter ambos os espetáculos em cartaz; porém, dado o baque político, as questões de "que" e "como" começaram a preocupar os artistas, desejosos de denúncia. Diante disso, adveio uma solução-resposta ao montar Andorra, de Max Frisch, pois esta peça poderia ser encarada como uma alegoria realista daquele nosso momento histórico politicamente autoritário - montagem mais visual, nela, Zé Celso desenvolveu com afinco a sua escrita cênica cada vez mais apurada, dando-lhe tons de protesto em prol da democracia e dos direitos humanos, embora a linha seguida ainda fosse a do "teatro cultural" e não a combativa, também presente no grupo. Na mesma temporada, Brecht entrou pela brecha de Andorra e marcou presença dentro da companhia, sendo muito utilizado em ensaios (e junto a Stanislavski); igualmente, Zé Celso foi para a Europa buscando fazer um contato mais direto com o ideário brechtiano, fato modificador da direção da empresa, pelo menos momentaneamente; de resto, o Oficina foi premiado pela primeira vez fora do país, indo ao Uruguai apresentar Pequenos Burgueses e Andorra e dialogar com outros grupos, aparecendo até na TV local.

No ano seguinte ao golpe, é notável a presença de inúmeras viagens e remontagens realizadas pela companhia, posta em má situação (como uma temporada carioca de Pequenos Burgueses), estando o local físico do Oficina alugado - Tempo de Guerra, de Boal, foi um dos ocupantes do espaço, naquele tempo. Também, um texto importante do repertório "oficineiro", traduzido por Zé Celso e Peixoto, despontou nessa época: Os Inimigos, de Máximo Gorki, primeiramente teve sua tradução censurada, mas depois foi liberado com alterações, o mesmo acontecendo com seus ensaios. Ainda, é pertinente dizer que um repertório baseado em Brecht 
foi ponderado pelo grupo a fim de ampliar o seu público (com $\mathrm{Na}$ Selva das Cidades, Tambores na Noite e Galileu Galilei), porquanto o dramaturgo alemão condizia com as finalidades do Oficina ao pensar em fazer dramaturgia, além da atração crescente por ele em função do material do Berliner Ensemble trazido por Zé Celso de sua viagem. Ademais, as trocas entre os teatros mais relevantes do momento - como eram Arena, Oficina e TBC - se fortaleceram em termos de ocupação.

Os Inimigos data de 1966 e foi uma grande produção que contou com a contribuição de atores convidados, além de uns poucos do Oficina, também indo ao Rio. O valor deste espetáculo deve muito à presença do teatro épico, fato propulsor da discussão de elementos stanislavskianos e brechtianos. Por isso, o ano em questão também demonstrou contradições, incertezas e hesitações do grupo (itens não raros) diante de suas renovações, em uma nova transição em direção ao engajamento, com historicismo e realismo crítico: censurada e liberada, esta peça sobre uma revolução russa não acontecida era claramente mais política e agressiva do que os trabalhos anteriores, dando espaço à luta de classes e aos protestos contra a burguesia progressista (identificada a parte da plateia). Porém, um fato de realidade desmoronou sobre a companhia: em 31 de maio de 1966, tempos de um show de Ary Toledo, o prédio do Oficina pegou fogo, rebocando consigo as primeiras resistências ao golpe. Para lidar com o futuro frente ao incêndio, os artistas programaram uma coletiva, se juntaram a outros nomes da classe artística e receberam muitos apoios, inclusive de políticos - é notável que, antes de se educar politicamente, Zé Celso flertou com a despolitização em tempos de crise, seja em negociações com o Estado ou pedindo verbas ao presidente, nesta ocasião. Deveria ter sido feito um grande centro cultural para reerguer o Oficina, algo, como sabemos, não realizado como planejado. Logo, reavaliando-se e transformando seus espetáculos em mercadoria, o grupo concebeu festivais retrospectivos (no Teatro Cacilda Becker e no Rio de Janeiro, por exemplo), reencenando Vida Impressa em Dólar, Pequenos Burgueses, Andorra e Quatro num Quarto (este, por último com direção de Zé Celso, pois tivemos mudanças de elenco e nos espetáculos, com o tempo).

Em um livro-retrospectiva sobre os anos de repressão nos palcos, Michalski (1989, p. 24-27) constata que o Oficina constituiu "o mais importante grupo em atividade" nos idos de 1966, embora Os Inimigos e Andorra flutuassem entre duas tendências da época, a brechtiana (muito explorada nos conteúdos dessas peças) e a mais anárquica (concernente à elaboração da encenação de Zé Celso, desenvolvida nos anos seguintes) - respectivamente, isso seria o exame metafórico de "temas políticos e sociais" e as disposições estéticas novas e eventuais, origem do "novo teatro": nele, revolucionando a linguagem teatral, os jovens reagiram a 
tradições e valores no teatro, afinados às repercussões da iminente "revolução cultural" ocidental, validando teoricamente suas práticas espetaculares através de estudos de Antonin Artaud, então reconhecido, e de alguns vanguardistas do teatro contemporâneo, como Jerzy Grotowski e o Living Theatre. No limite, pode-se dizer que essas vertentes, vindo à tona animadas por repertório e influências estrangeiras, conseguiram ultrapassar a crise ocorrida no referido ano e denunciada pelo teatro de esquerda.

Durante um período passado no Rio de Janeiro com Quatro num quarto, houve um lapso ocioso durante os dias, quando o Oficina fez alguns cursos, dedicando-se ao avanço intelectual e prático e investigando realidade e cultura brasileiras. Dentre essas atividades, o Laboratório de interpretação, com Luiz Carlos Maciel, foi marcante, pois, mesmo sem métodos e fins específicos, nele, os atores refletiram sobre a então atual insatisfação com o fazer teatral - anteriormente, eles haviam repetido espetáculos sem reagirem politicamente ao momento histórico -, foram até o inverso do conhecido método stanislavskiano, no sentido de experimentação gestual e de exteriorização da crítica à realidade, e releram $O$ Rei da Vela, de Oswald de Andrade, peça de trinta anos que deu ensejo ao espetáculo originário da nova vida da companhia (de revolução cultural, uma libertação própria e de seus embates ideológicos). Antes disso, tinha-se demandado a novos dramaturgos peças relacionadas à realidade do momento nacional para promover uma comunhão entre as artes, mas nenhuma chamou muito a atenção. Sem saber o que buscavam, nem como fazê-lo, os artistas do Oficina finalmente obtiveram as respostas cênicas e sociais procuradas (como tema, linguagem, estrutura, ideologia e objetivo) graças a $O$ Rei da Vela. Zé Celso já conhecia o texto, mas nunca havia se encantado por ele (achava-o panfletário), só ali reconhecendo um novo jeito de descortinar a nossa realidade nacional, formal e ideologicamente - folheando uma revista Time ao trabalhar O Rei da Vela, ele enxergou a peça, na qual sentiu realmente criar pela primeira vez: era o imperialismo americano devorado antropofagicamente pelo Brasil colonizado. Espalhando-se no panorama daquele ano, o espetáculo ainda insuflou um movimento de criação em variadas artes, o "Tropicalismo"

\footnotetext{
${ }^{16}$ Pode-se notar aproximações entre $O$ Rei da Vela e a Tropicália, começada na mesma época, sobretudo em elementos visuais; todavia, é justo observar o fato de Zé Celso não se declarar tropicalista e até ter questionado a existência desta corrente - para ele, criada pela burguesia industrial por meio da mídia (dentro da qual o Tropicalismo exerceu muito poder e o próprio chefe do Oficina representava o teatro contracultural), diante da emergente revolução na cultura. No máximo, o diretor diz ter havido uma convergência geracional de explosões entre movimentos artísticos contestatórios, que buscavam combinar ancestralidades e modas internacionais na arte - tivemos diversas rupturas culturais e sociais, incluindo-se nisso a revolução do teatro, com o próprio Zé Celso se descolonizando e se ligando, ao mesmo tempo, ao seu momento histórico e ao resgate da verdadeira história brasileira. Para além do seu $O$ Rei da Vela, a instalação de Hélio Oiticica, originária do termo "Tropicália", em 1967, a guitarra elétrica e o uso inovador da câmera cinematográfica foram consideráveis. Alguns tropicalistas, por sua vez, já indicaram a influência do espetáculo em seus trabalhos (como Caetano
} 
planos interrompidos, antes, foi igualmente destacável a nova versão de Quatro num Quarto, dando margem a uma nova e mais debochada interpretação, já em direção às descobertas vindas com Oswald, ocorridas quando as pesquisas mudaram a trajetória e interditaram influências antigas. Aquela conjuntura refutava a esquerda pré-golpe e o teatro europeizado, de padrões estéticos e comportamentais institucionalizados, indo no sentido de uma linguagem teatral mais corporal.

Na missão de $O$ Rei da Vela, a equipe desassossegada estudou e destrinchou a realidade do país acossado pelo imperialismo, desde política e economia, até literatura e história, sempre atentando para os desdobramentos burgueses. Ainda, frente ao encanto e à identificação com o filme Terra em Transe, de Glauber Rocha, o Oficina dedicou a peça ao diretor, o qual lhe apresentava "um universo de deboche sacrílego e destrutivo nos programas de Chacrinha.” (PEIXOTO, 1982, p. 62). Portanto, com a carnavalização espontânea como método de reflexão e acreditando-se um grupo à margem, o elenco questionou artistas e intelectuais, revelou novidades à arte e realizou uma nova crítica social à burguesia (principalmente relativa a domínios e torpezas), teoricamente responsável pela derrota de 1964, usando-se de comunistas e social democratas como alvos do enredo:

O Rei da Vela foi uma desenfreada descoberta crítica do Brasil. Uma implacável e impiedosa revisão de valores que começava agredindo a nós mesmos, numa etapa de um vertiginoso processo de libertação de preconceitos e formação cultural colonizada. E terminava agredindo o público, inclusive a chamada elite intelectual e política, porque devolvia uma imagem crítica constituída basicamente de deboche e irreverência, não poupando mitos e estereótipos, investindo com fúria avassaladora contra códigos sacralizados de comportamento. Incorporando a postura livre e anárquica proposta por Oswald de Andrade, nosso espetáculo não conhecia limites em sua ânsia de questionar o que para nós significava a essência do processo ideológico e político tanto da direita quanto da esquerda. Decidimos questionar o público habitual, que nos parecia anestesiado e adormecido, e assim questionar também o próprio teatro. Estávamos todos profundamente sufocados pelas conseqüências cotidianas de 64, atingidos por uma impaciência incontida, atacados de uma rebeldia irada, marcada pela perda de ilusões e pela descrença nos projetos reformistas e pseudo-revolucionários. O Rei da Vela foi uma forma de realizar uma espécie de radiografia do país, revelando sua podridão, seu tecido interno canceroso e assim mesmo resistente, porque se renovava em nossa passividade e em nosso ingênuo conformismo. Transformou-se assim numa bandeira radical, num manifesto político-cultural explosivo e criativo. Todo nosso irrefreável e desmedido vômito ganhou uma estrutura orgânica e trabalhada em seus mínimos detalhes. A liberdade de criação, que diariamente rompia nossos próprios limites, nos revelando inclusive um potencial insuspeito, não ficou caoticamente perdida no improviso, mas, ao contrário, conseguiu ser disciplinada e racionalizada. José Celso, finalmente fiel a si mesmo, alcançou um nível de escrita cênica surpreendente e fascinante. Vomitou seu passado e sua poética pessoal. O elenco lançou-se, num ímpeto estimulante, na elaboração de uma nova postura de interpretação incorporando até mesmo sem

Veloso, que, inspirado, logo lançou o "Tropicália"), e, sobretudo, a ascendência comum de Oswald de Andrade no aparecimento de um movimento em fins de 1967, quando trabalhos articulados se identificavam sem nenhum acordo prévio. Depois, tal processo entrou cada vez mais no corpo e desaguou em uma Roda Viva coral. 
provincianismo, conseguindo somar o aprendizado das sugestões de Brecht a algumas das mais espontâneas e trepidantes manifestações do teatro popular brasileiro. Misturando circo e teatro de revista, ópera e teatro crítico, rigor gestual e avacalhação, ritual e pornografia, protesto e festa. Um ato de ruptura com o passado. Um marco no teatro nacional. (PEIXOTO, 1982, p. 60-62)

Montado em pouco mais de um mês, o espetáculo estreou em setembro de 1967, na reabertura da casa após o incêndio ${ }^{17}$, e, apesar do estilo italiano, inovou com a presença de um palco giratório inspirado em Brecht, admirando ainda mais a plateia, recheada de convidados que haviam contribuído com a agora "Sociedade Civil Cultural Teatro Oficina". Complementarmente, na mesma ocasião, foi aberta uma exposição de fotos sobre o Berliner Ensemble (cedidas pelo grupo) no porão do teatro, a ser visitado durante intervalos. A peça surpreendeu, sendo elogiada pela crítica em geral, mas impactando e combatendo a recepção burguesa tradicional e preocupando os poderosos: a controvérsia e a agressividade desencadearam reações, pois, diante da divisão de crítica e público, as autoridades condenaram o espetáculo, chegando ao ponto de a censura federal modificar o texto e proibir as apresentações após o estabelecimento do AI-5, embora algumas marcações já tivessem sido alteradas (pela suposta "pornografia" do falo de um boneco e de um sorvete). Assim, a temporada de estreia despertou amor e ódio, dando origem ao sucesso, mas, também, a ataques e ameaças verbais, quando a segurança ainda era pouca e as censuras estadual e federal brigavam por autonomia - isso tensionava o trabalho. O Rei da Vela igualmente fez carreira no Rio de Janeiro e na Europa, para onde foi no ano seguinte ao da estreia. Por fim, o Oficina acabava com o teatro cultural e chegava ao seu momento de auge na nossa história teatral, que iria até o seu espetáculo seguinte.

O manifesto escrito por Zé Celso na ocasião de $O$ Rei da Vela deixa clara a sua interpretação da obra de Oswald (como vimos, unindo circo, teatro épico, chanchada, teatro de revista, ópera, tragédia, comédia, crítica, protesto, seriedade, deboche, ritualidade, festa, sexo e muita raiva), fora a empolgação da companhia em torno do autor, possuidor de superteatralidade, poder de síntese e liberdade de criação. A peça de Andrade é desbaratada, atravessada pela autoironia, podendo ser até difícil enxergarmos nela um engajamento profundo ou uma certa coerência; contudo, é ácida no apontamento político - nos anos 30, o capital era o alvo; em 1967, este é a base do regime militar. Dessa forma, o teatro começa a "jogar na cara" da classe média a culpa pela situação, mediante um texto de trinta anos e de uma postura de desancar tudo, bastante tropicalista em seu jeito de se engajar.

\footnotetext{
${ }^{17}$ Para a primeira reconstrução, como o objetivo do Oficina era criar um centro cultural, os arquitetos Flávio Império e Rodrigo Lefèbvre conceberam um teatro a princípio provisório. Em 1983, este lugar foi desapropriado e logo demolido para a realização do projeto de Lina Bo Bardi, o atual edifício teatral da companhia desde 1993.
} 
No teatro de 1967, de acordo com Michalski (1989, p. 28), cresceu a "reação anárquica às pressões" sobre o país, principalmente por meio de O Rei da Vela, a “consagração de uma verdadeira proposta estética e cultural" nova para o nosso teatro, influenciadora da sua geração: ocupando-se da crítica do corrompido capitalismo brasileiro e apartando-se das referências teatrais anteriores, o texto, escrito em 1933 e publicado em 1937, mas nunca montado antes, parecia se adequar à inconformidade dos jovens sessentistas e acabou originando o "espetáculo-manifesto" do Oficina. Além disso, Michalski (1989, p. 30) destaca a qualidade da montagem ao expor "o painel crítico da realidade brasileira", algo que demandou um trabalho analítico minucioso e pioneiro, e "a violenta e grotescamente estilizada escrita cênica" do diretor (combinando farsa, ópera e revista), afinada às suas ideias teóricas.

Em sua reconstrução da historiografia teatral, Prado (2009, p. 101-105) percorre caminho paralelo ao falar das agitações mundiais que deram esperanças políticas e humanísticas e explodiram em 1968, no Maio Parisiense, quando revolução e anarquia motivaram os estudantes: a essa altura, diante da arte sempre revolucionada, o palco era dominado pelo teatro do absurdo, o qual não existiu sistematicamente no Brasil, mas resgatou Artaud e deu vida ao teatro da crueldade ${ }^{18}$; como sintoma, já em meados de 1967 (e crescendo em número em 1969), até mesmo autores teatrais identificados com a esquerda se mostravam descontentes com o nosso teatro político, requerendo uma liberdade diferente para criar personagens também diferentes do normal ("contra a ordem" social, fosse ela burguesa ou esquerdista), assim acolhendo elementos do inconsciente e rompendo com a verossimilhança e "as regras dramáticas" presas à racionalidade. Por essa época, surgia o viés denominado irracional.

Logo, ao afirmar que o vanguardista teatro da crueldade promovia "uma revolução estética a partir do espetáculo", em vez do texto, e contava com a disposição dos encenadores como algo central, Prado (2009, p. 111-112) situa o Oficina enquanto o seu imprescindível exemplar brasileiro - embora essa opinião seja questionável: a companhia teria mostrado já em Pequenos Burgueses a "maioridade" do nosso teatro, possuindo riqueza de meios e qualidades cênicas e ideológicas. Ainda segundo Prado (2009. p. 112-114), o grupo proporcionou, principalmente no seu "apogeu", O Rei da Vela, "o aqui e agora" do teatro brasileiro: por um lado, tínhamos marxismo como luta de classes e como guerra imperialista

\footnotetext{
${ }^{18}$ No "Primeiro Manifesto" do Teatro da Crueldade, Artaud (2006, p. 114) define a própria crueldade: “Sem um elemento de crueldade na base de todo espetáculo, o teatro não é possível. No estado de degenerescência em que nos encontramos, é através da pele que faremos a metafísica entrar nos espíritos".
} 
entre países desiguais (com críticas ferozes ao capitalismo e à dependência dos EUA), sexualidade caricatural afrontando a moral tradicionalmente burguesa, paródias de "antiteatro", "espinafração" oswaldiana diante das derrocadas do levante de esquerda, anarquia na revolução, nacionalismo às avessas e engendrando o Tropicalismo no teatro (uma festa de aceitação do nosso subdesenvolvimentismo), e, usando-se do anacronismo do autor, crítica ao fracasso para o golpe e à burguesia, em vez de ao regime militar - como dissemos na introdução deste trabalho -, chocando a recepção através do foco no sujeito individual e da loucura, pois essa não era a revolta que o teatro político de esquerda (leia-se Arena) estava acostumado a realizar; por outro lado, havia formas primitivas e um espaço de trabalho criativo dado ao encenador, o qual imaginou um universo e explorou principalmente as suas obscenidades.

Tal era a tendência de uma geração agregadora de "arte e revolta", vendo no teatro um ato de revolução e na representação uma vivência, conforme diz Prado (2009, p. 114-115), talvez aludindo à contracultura: sob influências de Grotowski e Living Theatre, com "a frugalidade, o desapego aos bens materiais, o erotismo, a volta à natureza, os tóxicos e laivos do misticismo oriental", o ator desnudava-se (fisicamente e em termos de personalidade), tinha-se o texto como pretexto para as ideias do encenador (quando não era improvisado em tempo de ensaio), incorporava-se o público na encenação cerimonial (sem a "cômoda privacidade" e nem sempre de boa vontade, mas obrigado), e buscava-se espaços, não necessariamente palcos, que propiciassem as "origens ritualísticas e religiosas" do teatro e as muitas relações de palco e plateia (corporais e espirituais). Pelo visto, o pesquisador localizou essa febre em momento distinto do que havia notado o crítico Yan Michalski, ao amplificar o barulho do teatro novo em 1966, até porque, com os estrondos legitimadores provocados pelo Oficina em 1967, realmente se olhou com mais atenção para os movimentos vanguardistas nos anos posteriores, ou seja, a companhia representou bem a passagem do teatro mais textual para o de prática e criação coletiva ou vivenciada.

Prado (2009, p. 115-116) também ressalta a falta de assiduidade desse "teatro sagrado" no Brasil; porém, sem deixar de enfatizar os concorrentes polos de atração do Oficina, dá importância ao que, com elementos disso, realizou Zé Celso no "teatro da crueldade brasileira”, como o próprio chegou a chamar a sua arte nos tempos de Roda Viva:

Dilacerado entre tendências opostas, entre a agressão e a comunhão, entre o político e o estético, entre a racionalidade brechtiana e o misticismo de Artaud, entre ciência e magia, o Oficina, emblema e guia de sua geração, viveu com a maior intensidade as contradições de um momento confuso e generoso, de negações violentas e esperanças desmedidas. (PRADO, 2009, p. 116) 
O Oficina possui veia crítica e isso nunca foi contestável, porém, o espaço do palco “italiano" já não era o bastante para as revoluções começadas ${ }^{19}$. A nova geração do grupo se deu conta disso em 1968 e detonou tal convenção, antes de a cultura popular ser brutalmente arrasada pelo AI-5:

\footnotetext{
"Explode o teatro de coro, a realização aqui e agora da utopia. O sentido de coro se infla com os movimentos de maio na França e nas ruas do Brasil."

Há pontos de contato e antagonismo entre $O$ Rei da Vela e Roda Viva. Elas são na realidade uma só peça, segundo Zé Celso. Enquanto a primeira analisa com violência os velhos clichês, questionando o próprio fazer teatral até então, a outra emerge como resultado "de uma coisa coletiva, parindo uma cultura mais bárbara, brasileira, incubada, que começa a fazer a antropofagia". (CORRÊA, 1981, p. 44)
}

Enquanto O Rei da Vela representava o Brasil na Europa - passou por Florença e Nancy e foi convidado para ir a Paris, diante de interrupções causadas por um maio de 1968 em ebulição, entre bombas e barricadas da revolta estudantil -, Zé Celso retornou para preparar a temporada paulistana de Roda Viva, espetáculo estreante em janeiro no Rio e em maio em São Paulo. Tal incursão fora do país foi financiada pelo próprio grupo, o qual, frente à negativa oficial do Itamaraty por razões morais, pediu vários auxílios e apresentou suas peças mais bem-sucedidas (Pequenos Burgueses, Quatro Num Quarto e Roda Viva) e o Show Oficina, mas não impediu o próprio endividamento e a falta de condições de voltar à Europa para aceitar os convites alcançados pelo sucesso da primeira ida.

O Rei da Vela voltou ao cartaz nos tempos da remontagem de Roda Viva, ao passo que outras ideias já rondavam o pessoal da Jaceguai, como Galileu Galilei, de Brecht, "uma espécie de revisão crítica do processo desencadeado por O Rei da Vela" (PEIXOTO, 1982, p. 72), e Poder Negro, de Everett LeRoi Jones, sopro radical contra a censura, realizado por Fernando Peixoto. A propósito, 1968 foi simbólico quanto à cruzada da arte (libertária e democrática) para sobreviver à arbitrariedade da censura progressiva em nossos palcos: o ano já anunciava ser trágico desde o começo, quando Roda Viva despertou violência em seus opositores (os quais fizeram de tudo para contribuir em seu impedimento), e arte e política se completavam, mas, também, se impugnavam; igualmente no início, nas capitais paulista e carioca, tivemos greves em teatros, atos manifestantes e confrontos de artistas com a polícia, por conta de uma campanha moral e ataques (até a bomba) contra o teatro. O mês de junho deste ano nos mostrou o ápice desse confronto, quando, frente à proibição da I Feira Paulista de Opinião, a classe artística paulista reagiu com protestos - conforme mencionamos no

\footnotetext{
${ }^{19}$ Em O Rei da Vela, havia uma somente ocorrência de descida à plateia, da personagem João dos Divãs.
} 
capítulo anterior -; ainda, as peças revolucionárias do Oficina, O Rei da Vela e Roda Viva, seriam interditadas em 1968, após ultrajes de paramilitares. Para a companhia, 1968 foi claramente atravessado pela violência e pelo caos, fato comprovado pelas montagens e repercussões de $O$ Rei da Vela, Roda Viva e O Poder Negro, que estremeceram terrenos e ecoaram até em outras expressões teatrais.

Querendo pensar sobre as implicações do trabalho cultural e/ou intelectual com a opressão, o Oficina arquitetou um repertório brechtiano aproximado da realidade brasileira e concebeu Galileu Galilei, retornando ao "diálogo crítico" e à tentativa de foco na razão. O ensaio geral deste espetáculo para os censores gerou uma estreia ocorrida junto ao estabelecimento do AI-5, em dezembro de 1968, na qual uma grade separou o palco da plateia, ficando o coro aniquilado, em um palco tradicional, e o teatro em um clima de suspensão. Peixoto, pertencente à ala mais "Arena" do Oficina, achava que a rota desenhada até ali iria ruir, mas que Galileu mostraria um percurso estético e ideológico bom para os tempos sombrios, com crítica social e pensamento sobre a realidade circunscrita, afastando o viés político irracional e radical anterior, isto é, acalmando as iras e expondo razão e ciência.

Apesar do sucesso, o coro voltou a ganhar relevo e deu origem a um racha decisivo da companhia, ocorrido no ano seguinte por causa de tensões e repartições em dois padrões de conduta cultural: transformando a ciência em ritual (advindo do coro de Roda Viva e origem de irracionalidade, a qual voltou com força em Gracias Señor), a famosa cena interdita do Carnaval corroborou divergências existentes, e ainda, a montagem despertou o Oficina, sobretudo Zé Celso, para novas correntes em direção ao misticismo e ao senso comunitário, presentes na contracultura. A história do grupo foi desenvolvida paralelamente ao trabalho de pesquisa e de improvisação desse coro, que foi, por um lado, em direção à busca de novos vínculos com a recepção teatral, e por outro, formar a "marginália" do Oficina, contraposta aos "representativos" atores mais antigos:

As divergências atingiam pela primeira vez, mas ainda de forma bastante atenuada, a própria direção. Certamente esta confusão toda teve sua origem no estado repressivo e sufocante da sociedade brasileira. Internamente o setor mais jovem do elenco pretendia exercitar e impor sua confusa idéia de um impreciso projeto revolucionário e transformador, revoltado contra o sufoco e o autoritarismo. Esta ânsia de destruir mitos e libertar sua espontaneidade criativa não tinha a menor hipótese de viabilizarse no plano sócio-político: o Oficina transforma-se num microcosmo criado a partir do imaginário e a batalha contra a opressão é transferida, por uma associação mecânica, para o interior do grupo. Enfim, a radicalização de um lado provoca a radicalização do outro. Mas, na verdade, até que um equilíbrio bastante razoável manteve a "guerra civil interna" num estágio pouco mais que latente: haviam certamente instantes de acirramento das contradições, de confronto de valores. Mas havia momentos de apoio mútuo e até confraternização. A divisão representativosmarginália era no fundo bastante falsa: o "conservadorismo" e o "revolucionarismo" 
poderiam ser facilmente identificados, naquele instante, naquele elenco, tanto de um lado como de outro. (PEIXOTO, 1982, p. 77-78)

Tendo em vista que o objetivo deste trabalho é adentrar um momento da história do Oficina, dado em 1968 e a ser analisado na seção a seguir, os anos seguintes a isso nos são de menor relevância ${ }^{20}$.

Constituindo uma resistência atuante em várias frentes artísticas (teatro, cinema, música, festivais, televisão, cursos, seminários, performances, atos sociais, livros e jornais), apesar das ameaças do regime político-econômico e da necessidade frequente de arrecadar fundos, o Oficina (e sua loucura bem pensada) atrelou-se demasiadamente a Zé Celso, seu "norte" desde muito cedo, não obstante ele nunca ter guiado o grupo sozinho, mas ser responsável pela sua importância em nosso cenário cultural.

\subsection{A viva roda do Oficina}

Zé Celso já declarou ter nascido realmente para o mundo em 1968, depois de $O$ Rei da Vela e para a feitura de Roda Viva, visto que o ano foi revolucionário em política e cultura e

\footnotetext{
${ }^{20}$ De acordo com estudos específicos sobre a história do Oficina - como Peixoto (1982), Tavares (2006), Silva (1981), Mostaço (1982), Corrêa (1981) e Martinez Corrêa (1998) -, outros elementos politicamente definidores avultaram na trajetória posterior do grupo. A companhia fez um intervalo mais importante em território nacional, em 1974, e seus membros foram trabalhar fora do país (sobretudo em Portugal e Moçambique), voltando em 1979 sob nova roupagem. Entre 1969 e 1974, resumidamente, podemos destacar: a montagem de Na Selva das Cidades, de Brecht, expondo mais batalhas entre coro e representativos; o recrudescimento de influências como Grotowski e Artaud, bem como da radicalidade e da violência; divergências políticas e questões empresariais; uma parada breve, para reorganizações, e a volta, três meses depois, em 1970; o filme Prata Palomares, feito em Florianópolis, com André Farias; a ligação de Peixoto com o Arena, onde se sentia identificado (em viagens e na montagem de Don Juan, de Molière, com Gianfrancesco Guarnieri); visitas e trocas com grupos internacionais (Os Lobos e Living Theatre), durante um tempo de crise e de entusiasmo pelo teatro de envolvimento e de vivência, terminado em debates; o desejo de formar uma comunidade de trabalho, pondo fim ao projeto empresarial, e de viajar, em busca de um trabalho novo; a excursão Saldo para o Salto, com algumas remontagens; a retomada da tendência ao coro, após o afastamento de figuras mais tradicionais da esquerda, como Peixoto, em 1971; o começo das longas filmagens de O Rei da Vela, cujo fim foi em 1974; a importante viagem pelo Brasil, como Comunidade Oficina Brasil, a fim de pesquisar a realidade do povo "ao vivo", no interior e nas periferias (em dez meses); o suposto crescimento do autoritarismo de Zé Celso; o fím da comunidade e das viagens, em 1971; o acontecimento de Gracias, señor, advindo da viagem, em 1972, com coletividade e improvisação coral; experimentos de te-ato, um novo caminho formal; o nascimento do grupo Pão e Circo, de Luiz Antônio Martinez Corrêa, no porão do Oficina; a reabertura dos debates de $O$ Rei da Vela e de Roda Viva diante da classe média com Gracias, señor; a transformação do edifício do Oficina em "Casa de transas", comandada pela contracultura e pela ausência de especificidade artística; a peça As três irmãs, de Anton Tchecov, como resultado das viagens; alguns fracassos e muitas evasões, inclusive a de Renato Borghi; a união de 1973 e 1974 em torno da nova Comunidade Oficina (do) Samba, com vistas a segurar o prédio; o surgimento do grupo Ananke, saído do Oficina; o término do filme de $O$ Rei da Vela, seguido por muitas prisões, a tortura do diretor, invasão e interdição, em 1974, ano do autoexílio. Além dos experimentos de Zé Celso, o único membro original, com outras formas de arte, durante a volta, em 1979, após ter ido a Cannes, a companhia mudou o nome para Oficina Quinto Tempo, e, na década de 1980, na qual começou o interesse de fato pelas lutas populares brasileiras, para o atual Teatro Oficina Uzyna-Uzona. Em 1980, houve uma ameaça de despejo, enfrentada pela vontade do grupo de adquirir o terreno e o prédio, refeito e reinaugurado em 1993, apesar de haver pendências até hoje com os proprietários dos entornos do teatro.
} 
originou um movimento de descolonização expandido até o nível físico - ao diretor, o Tropicalismo também teria a ver com o processo de descolonizar um "corpo social rejeitado". Em tese, Roda Viva é a expressão da primavera de 1968 no Brasil. Ainda sob a ressonância da radicalização estudantil, devido à situação política, da provocação violenta de $O$ Rei da Vela e da máxima oswaldiana "tupi or not tupi", Zé Celso encarnou a função do (seu) teatro do momento: desestabilizar zonas de conforto, ou melhor, desmascarar determinadas representações sociais através de humor, penetração em si mesmo e agressão estética. Isto posto, Roda Viva, conforme o próprio encenador, foi um acontecimento cosmopolítico.

Internalizando essas intenções, o Teatro Princesa Isabel (RJ), e depois, o Teatro Ruth Escobar (SP), foram tomados por treze pessoas que faziam uma revolução (o coro). Portanto, a onda libertária de 1968 emergiu e estampou-se no coro, o legítimo protagonista de Roda Viva: a revolução se dava fisicamente, batendo no corpo, e o coro atuava com uma garra de time de futebol - era um "coro que pega o tempo no corpo", segundo palavras de Zé Celso, em uma conversa descompromissada realizada em Porto Alegre no dia 17 de outubro de 2018.

Além do mais, sem abrir mão de uma convicção com a qual concordamos, o diretor ainda rechaça o adjetivo "irracional", dado pela crítica sessentista tanto para ele quanto para a peça, conforme examinaremos, declarando ter sido deveras racional; nesse sentido, as drogas (ácido) proporcionavam-lhe uma saída apenas momentânea da racionalidade. Anos após ter tomado o partido do "pessoal do coro", da "ralé", no maior racha ocorrido internamente no Oficina, ele defende até os dias de hoje este lado do grupo - levando-se em consideração a remontagem do espetáculo estreada em 2018 pelo Oficina, justamente nessas bases. Logo, durante a rápida e intensa preparação do primeiro Roda Viva, ensaiado em menos de vinte dias intensos, ele encontrou e permaneceu com os atores do coro, numa alegria de estar em cena e fazendo conviver a diversidade deste conjunto, pois o espetáculo mostrou viveza:

\footnotetext{
Sua força estava no coletivo. Foi esse coro que invadiu a cena, impôs seu gosto, sua estética, suas relações de produção e criação. Foi esse coro que avançou sobre o público, ocupou a sala, saiu para a rua e foi empurrado de volta para jaula do palco, através dos dois atentados do Comando de Caça aos Comunistas. (MARTINEZ CORRÊA, 1998, p. 130)
}

Então, quando Zé Celso diz que "o coro dirigiu a peça" e que "o coro estuprou a peça", é possível compreender o clima de feitura, o grau de Tropicalismo do espetáculo em termos coletivos e o quanto o texto buarqueano serviu-lhe de mola propulsora para a revolução necessária de 1968, ano de reestruturações em nível mundial: 
O texto pedia quatro pessoas no coro. Mas quando abrimos os testes para atores cariocas. Veio uma multidão e tomou o espaço, sem saber o que era palco ou o que era platéia, se o ator poderia tocar nas outras pessoas ou não. Era uma geração que trazia em si todas as revoluções. [...] 1968 é um retorno ao paganismo. Para mim, o desbunde foi mais importante do que a luta armada, que eu apoiei, participei e fui torturado por tê-la apoiado. Não me arrependo, foi certo. Mas fazendo um balanço geral vejo que a turma que foi para a luta armada não quebrou os padrões positivistas, os padrões de vida mesmo, não se descolonizou. A descolonização houve no momento onde a gente se re-ligou ao nosso passado arcaico e foi descobrir o índio e o negro na gente, o fã da rádio Nacional, o cara que gosta de música pop, o cara que começou a misturar, comer tudo, comer de tudo.

Roda Viva não foi feito nem pelo Chico, nem pelo Flávio, nem por mim, foi feito por aquela multidão do coro. Os protagonistas não tinham a importância que tinha o coro. Mas na época os fotógrafos eram tão condicionados, que fotografaram só o palco, é raríssimo você ver fotografias do coro, que se espalhava no meio da platéia. (CORRÊA, 1983)

Seguindo a nova corrente ideológica do Oficina, o diretor montou Roda Viva, mas, depois, ele reformulou o movimento da seguinte forma, em 1980:

Roda viva vem com o movimento de massas, com o anarquismo internacional da época, com o movimento de 1968, com a juventude. O rei da vela é movimento dentro do Oficina, uma atitude radical dentro do grupo, seus atores querendo devorar e destruir tudo que os amarrava. Devorar tudo com muita força, com muita violência, apoiados na incubação do popular, teatro de revista, Rádio Nacional etc. Mas, na verdade, muito motivados por um sentimento de vanguarda. Já Roda viva é um passo adiante. É como se $O$ rei da vela fosse um tiro que a gente dava, virando a mesa, abrindo um buraco no sistema cultural brasileiro, denunciando esse sistema, mas deixando um buraco aberto. Por esse buraco passa então Roda viva. Eu vejo assim: $O$ rei da vela no palco, uma coisa de palco; Roda viva uma coisa viva na platéia - as duas montagens formando um quadro só.

[...] Era uma peça da platéia. Uma peça do coro. Quem fez Roda viva foram os meninos que vieram fazer o teste para interpretar o coro. Eles trouxeram para peça o espírito de 68. Foi isso que me fundiu a cabeça, a força dessa turma, a força que tinham os jovens em 68. Um tipo de gente muito inventiva: você não sabia se era homem, se era mulher, se era feio, se era bonito, pobre ou rico... Um bando fez o teste e aquele teste foi Roda viva. E a minha cabeça cresceu muito naquele combate. [...] Para mim, Roda viva é a reviravolta, a revolução do teatro brasileiro. O rei da vela prepara o caminho e Roda viva faz a revolução. E vem de uma maneira bruta. (MARTINEZ CORRÊA, 1998, p. 305-307)

Em uma entrevista mais contemporânea, Zé Celso destaca a grande importância (descoberta posteriormente), para o nosso teatro do século XX, de Roda Viva e do seu coro, este último movimentando-se do palco à plateia, mesclando ficção e vida real e ocupando a obra toda; dessa forma, a peça se torna imprescindível aos olhos do encenador, porque resgata o coro grego, "um coro de protagonistas" que faz da plateia um outro ator, e dá relevância a uma parte subestimada e até pouco registrada nas fotos do espetáculo. Na própria obra do líder do Oficina, tal acontecimento foi marcante, pois ele passou a montar outros coros desse tipo, embora sem as mesmas força e relação com os espectadores - em Galileu Galilei, por exemplo, o vínculo era interdito, visto que os artistas tiveram de ficar no palco e não puderam 
nem olhar para a plateia. Percebendo relações entre as transformações de ídolo, coro e gosto da indústria, ocorridas na peça, o diretor ainda retoma as origens desse coro e libera as suas revoluções, constatando uma roda-viva real: assim como Benedito vira Ben e, depois, Benedito Lampião, o Povo e as macacas de auditório seriam também manifestantes panfletários:

\begin{abstract}
Quer dizer, era essa metamorfose que o mercado daquela época criava. Havia uma grande movimentação cultural. O mercado começou com a Jovem Guarda, a Jovem Guarda caiu fora de moda quando apareceu a música de protesto e o Geraldo Vandré, então veio tudo aquilo, os festivais... E depois disso, veio a repressão para aniquilar. Quando a repressão vai se fechando, o que sobrevive é a Tropicália. Em Roda Viva o Chico constrói uma máquina. E ele só a inventa porque passou por ela. Ele está nela. Nós estamos nela. A peça era muito simples, muito bem escrita, os diálogos muito bons, do tipo Nelson Rodrigues. Com um jeito gostoso de falar. As músicas eram lindas, e já no texto tinha um coro de quatro pessoas.

[...] Mas era um coro em duas dimensões, que não ia para a plateia. Ele ficava no palco italiano, é backing. Quer dizer, ele não é um coro. Porque o que aconteceu de significativo em Roda Viva foi a dimensão que tomou o coro. [...] Depois de uns quinze dias de ensaio eu abri testes para escolher as quatro pessoas. Mas resolvemos ficar com todas que apareceram. Porque elas chegaram e invadiram aquele teatro. Era o teatro Princesa Isabel, um teatro super feio. O coro chegou e tomou conta. Eu estava muito inspirado, estava muito solto, preparado por $O$ Rei da Vela. Tanto que eu considero Roda Viva o segundo ato de $O$ Rei da Vela. As coisas se completam. [...] E Roda Viva retomou ainda mais o tipo de ator que havia na Grécia Antiga, coisa que eu só soube depois quando fui estudar As Bacantes. Eles tinham um fogo forte, e tinham, como dizia o Plínio Marcos, uma coisa extremamente necessária no teatro, que é uma excitabilidade. E cada um deles trazia o embrião de todas as revoluções que foram acontecendo depois, separadamente: a revolução ecológica, a sexual, a religiosa, a estética, a alimentar, a revolução das drogas... Um pouco em cada corpo. Os jovens de 68 pediam a imaginação no poder. E naquele coro emergiu uma força humana que dançava, cantava, que tocava nas pessoas, sem barreiras. Iam para o balcão, para cima, para baixo, se expandiam. E aí nasceu a peça. Uma peça que transcende tanto a autoria do Chico quanto a minha direção. Quer dizer, quem criou a peça foi aquela geração. [...] O coro passou a ser estrela... Eu via que cada indivíduo, mesmo os mais feios, tinha um interesse. (CORRÊA, 2012, p. 5-6)
\end{abstract}

Portanto, na mesma conversa mencionada, Zé Celso pôde concluir que o teatro, nos termos vividos pelo Oficina e pelo grupo que pôs em prática a sua Roda Viva, é uma bruxaria explodida em 1968, após ter vivenciado a crise do teatro e o primeiro sinal revolucionário e antropofágico apreendido em 1967, com O Rei da Vela - ambos os espetáculos radicalizaram a forma e flertaram com a violência.

Como é sabido, Roda Viva foi o primeiro texto dramatúrgico do jovem compositor mpbista Chico Buarque de Holanda, tendo sido escrito por ele em 1967 e montado no ano seguinte pelo diretor do Oficina, convidado juntamente com o cenógrafo Flávio Império (o mesmo de Arena Conta Zumbi, do Teatro de Arena, que, juntamente com Zé Celso, havia convivido com Chico em Os inimigos), também escalado para o trabalho independente. Ademais, poucos intérpretes da companhia estavam presentes em Roda Viva, até porque $O$ Rei 
da Vela ainda estava em atividade quando houve a outra estreia; sendo assim, o grande elenco aclamado por Zé Celso, contando com Heleno Prestes, Antônio Pedro, Marieta Severo, Flávio São Tiago e Paulo César Pereio (Rodrigo Santiago substituiu Heleno Prestes e Marília Pêra substituiu Marieta Severo quando a peça foi para a capital paulista), mesclava cinco atores renomados e treze novos colaboradores, chamados após um teste que encantou a direção e aprovou a todos. Estes últimos, como vimos, foram de extrema importância para a concepção do coro descoberta pelo encenador (de canto, dança e representação; mas, diferentemente da Broadway, com brasilidade e violência), bem como para a mudança chegada ao grupo, o qual sofreu uma significativa cisão interna posteriormente (consolidada a partir de Galileu Galilei e Na Selva das cidades), origem da oposição "ralé" versus "representativos": vindos do Conservatório carioca e, mais profundamente, da classe média degradada, usando-se do corpo como forma de sobrevivência, ainda sem vícios e receios com a arte, porém, demonstrando pouca técnica, a qual era contrabalanceada por espontaneidades e vivacidades necessárias ao momento, os jovens "porraloucas" da "massa" desafiavam os veteranos, detentores de técnicas e cursos de atuação em seus currículos, os quais, como personagens e estrelas, completavam esse quadro agressivo ao público. A parte musical do espetáculo, igualmente composta pelo autor, foi desempenhada pelos músicos orquestrados por Carlos Castilho. Com base em muita confiança e plena criação, o trabalho foi totalmente concebido em conjunto: música, cenários, figurinos, produção e encenação.

Primeiramente, a montagem teve sua estreia no Rio de Janeiro, passando ilesa pela censura (certamente contando com a fama de Chico Buarque para isso) e lá permanecendo por três meses; depois, no entanto, repressões marcaram a temporada paulistana, passando-se a produção da peça de Orlando Miranda a Joe Kantor e à dona do teatro que a acolhia, Ruth Escobar. Consequentemente, o cartaz desfrutou das imagens do autor, já conhecido na música, e do Oficina, companhia do diretor, muito em função do boom causado anteriormente por $O$ Rei da Vela. Sem separar as duas formas de expressão teatral (texto e cena), Zé Celso já reconheceu ser beneficiário de Chico, por sua popularidade e pelo tema atrativo de Roda Viva: "Mas é evidente que o caso da peça se trata de um material de Chico Buarque, o sucesso crescerá. [...] Neste sentido acho que a peça será de imenso sucesso, pois ela trata de um fenômeno nacional e foi escrita por outro fenômeno nacional." (BUARQUE; CORREAA, 1968). A crítica não costumava valorizar o texto buarqueano, pelo menos até 2018 , ano da montagem renovada, feita pelo Oficina Uzyna Uzona. Tido como roteiro servil ao teatro da crueldade brasileiro (termo a ser visitado) de Zé Celso e apresentando vida e morte de um ídolo, o escrito foi liberado sem cortes pela censura, contando apenas com uma taxa 
classificatória de quatorze anos, logo estendida até dezoito anos.

Roda Viva foi a única produção da qual Zé Celso teria participado fora do Oficina, embora se costume atrelar o espetáculo ao grupo, que também o requere e chegou a remontálo recentemente. De fato, a radicalização era oficialmente do diretor, mas a renovação atingiu o grupo inteiro:

O Oficina se confunde bastante com José Celso, mas talvez não a este ponto. Na verdade, Roda Viva não teria sido, naquele momento, produzido dentro do Oficina. A equipe de direção havia ido sem dúvida bastante longe, mas não acredito que aceitasse totalmente aquela experiência ainda mais funda e radical num experimentalismo de agressividade que chegava a provocar e atingir fisicamente os espectadores. Trata-se, é preciso afirmar, de um espetáculo extraordinário. O texto de Chico, que chegou a estar antes em cogitação no Oficina, era apenas um roteiro. Algumas cenas com sugestões estimulantes, outras mais acabadas, outras menos estruturadas. José Celso, depois de $O$ Rei da Vela, teve uma compreensão lúcida e sensível do material que tinha nas mãos. Soube retirar do texto imaturo um espetáculo inesperado e surpreendente inclusive pela coragem de penetrar, sem pudor, no desnudamento do mito. Um ímpeto tribal definia a vitalidade intensa do espetáculo. José Celso concretizou cenicamente a violência de um desabafo autêntico, denunciando uma experiência vivida pelo próprio autor: Roda Viva implacavelmente volta-se contra uma engrenagem que domina, molda e consome seus ídolos, depois de transformá-los em objetos de consumo, utilizados para mistificar a verdade e ajudar a institucionalizar a mentira. (PEIXOTO, 1982, p. 6667)

Reafirmando elementos da peça anterior, a montagem triunfou no Rio de Janeiro, em São Paulo e em Porto Alegre, porque, ao contrário do que se pensava, ela chamava a atenção do público. Todavia, Roda Viva foi proibida nacionalmente pela Censura Federal, por motivos de polêmica e perigo à segurança nacional, e posteriormente vetada por Chico Buarque, estremecido com Zé Celso - punição injusta após as ameaças e ataques sofridos, advindos de ramos da direita até hoje impunes. Pela mesma brecha, O Rei da Vela e a I Feira Paulista de Opinião foram igualmente censuradas e o público burguês afastado pôde retornar tranquilamente às cadeiras da plateia e ao sustento dos cartazes. Dessa forma, embora tivesse havido protestos e alguns abandonos de sessão, não podemos deixar de relatar os revides violentos à Roda Viva, ocorridos antes do AI-5, com maior estardalhaço no Teatro Galpão, do Ruth Escobar, quando da temporada paulistana, herdeira direta do grande sucesso da temporada carioca, e no Teatro Leopoldina, em Porto Alegre. Como se sabe, no primeiro caso, em 18 de julho, após assistir diversas vezes à encenação, cerca de vinte homens, entre os 110 militares e civis envolvidos - identificando-se como parte do Comando de Caça aos Comunistas, congregação miliciana que crescia no país e alertava os governantes -, invadiram o teatro após o término do espetáculo "subversivo" com armas, cassetetes, soco-inglês e bombas de gás lacrimogêneo, e, em três minutos, depredaram o espaço e o equipamento, 
prenderam atores nos camarins e agrediram principalmente as atrizes e parte da plateia restante (eram onze e meia da noite). Entre equipe e público, conseguiu-se deter dois criminosos, nos quais a polícia parece ter dado sumiço ou liberado; ainda, os policiais de guarda na entrada do teatro, já previamente ameaçado, não impossibilitaram a ação atroz, nos levando a acreditar em negligência e em um acordo com os militares, tendo em vista a conhecida contrariedade das autoridades com relação à peça. No entanto, a propaganda gratuita rendeu mais público apoiador e glórias ao tempo restante de carreira do espetáculo, mas, também, endossou ataques morais (sobre violência, imoralidade, libertinagem, obscenidade, pornografia, etc.) iniciados anteriormente, nas comunicações e na política havia debate em Assembleias Legislativas e Câmaras Federais -, ramos defensores morais de Chico Buarque e do próprio teatro. Perante as acusações dos deputados Conceição da Costa Neves, Aurélio Campos e José Carvalhares (de que Roda Viva teria desrespeitado a democracia e as tradições para promover uma revolução social), o diretor respondeu com a lotação das apresentações, desmistificando a moral preconceituosa e hipócrita dos bordéis (ao que o teatro era relacionado) e denunciando o universo escuso dos cidadãos "de bem” com arte, prazer e razão; considerando o sexo como algo saudável e divertido, a peça não era pornográfica, o que também não lhe seria um problema, somente outro tipo de arte. Mesmo com a repressão havida, aquela geração já tinha imposto certas transformações. Portanto, após o episódio do CCC, o Oficina parece ter sentido a necessidade política de continuar "batendo" em quem não fazia nada contra o autoritarismo, voltando ao cartaz com o apoio "oficial" da Polícia Federal e uma segurança ostensiva própria, apesar do medo reinante.

No segundo atentado mencionado, já em 3 de outubro, cerca de trinta paramilitares e membros do exército agrediram e sequestraram os artistas após a estreia porto-alegrense, conduzindo-os à censura total. Analisando a temporada gaúcha, diante da distribuição de um panfleto acusatório, antes da única apresentação realizada em Porto Alegre, da pichação do teatro, em seguida (dizendo: "Fora, agitadores", "Abaixo a pornografia" e "Comunistas"), da apressada proibição da peça em todo o país, pelo Departamento de Polícia Federal, e da perseguição e ataque do Terceiro Exército aos artistas (próximo a um hotel e em uma casa, incluindo-se o sequestro da atriz Beth Gasper e do músico Zelão por policiais) - tudo terminado no retorno forçado a São Paulo, com um claro tom moralizante e repressor, típico do período político militar -, pode-se concluir, juntamente com Ventura (2008, p. 202-207), que o mais relevante "escândalo cultural" de 1968 mostrou uma face diferente do engajamento artístico brasileiro: 
A peça Roda viva transformou-se em autêntico show depravado, numa constante sucessão de cenas atentatórias à moral e aos bons costumes. Toda gama de atos libidinosos e de mímica pornográfica era apresentada no palco, culminando com um indiscutível ato sexual. Como se não bastasse, conclama "o público burguês" a se levantar, incitando-o a derrubar a "ditadura que se implantou no Brasil", objetivando a imposição de um "governo popular". Nem processo de ridicularização, apresenta artistas com indumentária de sacerdotes, soldados e, inclusive, a Virgem Maria sendo possuída pelo anjo. Há cenas de "mulheres com mulheres" e de "homens com homens" e muito palavreado subversivo. (Nota do DPF, apud VENTURA, 2008, p. 207)

A respeito do diretor, Costa (2016, p. 193) lembra da entrevista histórica de Zé Celso a Tite de $\operatorname{Lemos}^{21}$ (a ser abordada mais à frente, neste trabalho) para enfatizar o desenvolvimento solitário de sua criatividade cênica, sem um grupo propriamente dito, ao trabalhar com um jovem e diferente elenco e exercer a sua "arte da direção", deixando claras as intenções de ultrapassar as fronteiras textuais e de compor baseado em elementos técnicos:

[...] em Roda Viva o repertório foi desde felação envolvendo a figura da Virgem Maria à devoração de fígado (representando o coração do ídolo televisivo). Por isso, também neste caso, a análise do texto deve preceder às considerações sobre o espetáculo. (COSTA, 2016, p. 193)

Nessa corrente, Costa (2016, p. 194) pondera que a linha seguida por Chico Buarque em Roda Viva é a mesma do Show Opinião, cujo texto também foi considerado um roteiro à montagem: concordando com a censura branda, mesmo porque os palavrões de Mané e a trajetória de Benedito não eram coisa grave ou diferente demais, para a pesquisadora, o texto de Roda Viva continha "algo mais" do que um roteiro, passando à frente do Centro Popular de Cultura (CPC) e do Grupo Opinião: "E principalmente: se não for pensado como tentativa de dar continuidade à reflexão estética sobre os problemas levantados pelo Opinião, o esforço de Chico Buarque perderá o seu mais importante significado.” (COSTA, 2016, p. 194). Comprovando isso, Costa (2016, p. 194) argumenta que os universos criticados dos dois espetáculos são comuns: enquanto um visitava a problemática da inserção do artista da música na indústria cultural por meio do rádio, o outro explorou o crescimento do mesmo negócio pela via da aclamada e recente televisão; portanto, Chico não descortinou nada inédito, embora tenha adotado outros ritmo e intensidade no tema do enredo:

\footnotetext{
${ }^{21}$ Conforme objetiva mostrar a presente dissertação, sabe-se que inúmeros rompimentos dos entornos de 1968 também ocorreram no polo das esquerdas: abordando este ponto, naquele ano, Zé Celso concedeu uma entrevista plena de posição radical a Tite de Lemos, intitulada "A Guinada de José Celso", a qual consideraremos na conclusão deste trabalho, juntamente a "Que pensa você do teatro brasileiro?", de Boal, uma vez que as duas falas são extremamente significativas para cotejarmos os engajamentos dos dois grupos estudados, conforme aquele momento decisivo.
} 


\begin{abstract}
O caminho de Chico Buarque começava por fotografar o povo miserável entregue à alienação religiosa, passava pela denúncia nacionalista da invasão cultural americana expondo os seus métodos de manipulação e o papel de sócio no processo desempenhado pela imprensa e terminava dando conta, indiretamente, do processo de radicalização política em curso no país, prontamente rebatido pela indústria cultural com o lançamento de sua versão pasteurizada da moda hippie. [...] em Roda Viva o recorte sociológico vai privilegiar um tipo especial de trabalhador: o músico proveniente da classe média. Da mesma forma, quando surge a agitação política, os protagonistas são estudantes em passeata. O dramaturgo está, pois, perfeitamente afinado com a ordem do dia do período 1967-1968. (COSTA, 2016, p. 195)
\end{abstract}

Chico Buarque costumava comentar que o tema de Roda Viva não era autobiográfico, mas sim um desabafo pessoal feito na época, centrado na desmistificação de mitos para ele muito conhecidos, não sendo a peça exatamente tragédia ou comédia, antes uma farsa musical não realista, apenas expositora de um acontecimento pontuado por um coro (como os gregos). Querendo dizer coisas não exprimíveis em música e a menos pessoas, ele se aventurou por uma nova linguagem, sempre negando fazer um teatro comercial. $\mathrm{O}$ seu texto era, como dissemos, um roteiro sujeito a modificações da encenação - isso foi dito pela crítica e pelo próprio autor, que não enxergava traços políticos ou socialmente engajados de maneira clara em sua peça, a defendendo dos militares dessa forma, embora a tenha recheado de baques culturais e antilirismo, incompatíveis com a sua própria imagem de "bom moço" da MPB, vendida até então pela TV. Logo, estando ele de acordo com a originalidade, a ousadia e a agressividade da montagem cênica, da qual presenciou a feitura, conscientemente surpreendeu e chocou o seu público musical cativo com uma postura mais rebelde. Este público queria distanciar o espetáculo da reputação de Chico, mas ele próprio idealizou Roda Viva como uma maneira de acabar com esta fama, para ele cansativa, atrelada ao mecanismo de uma cultura de massas - prova disso foi o lançamento, ocorrido anteriormente, de sua música Roda Viva, aclamada em festivais e introdutora da intenção. Nesse sentido, através do teatro, o seu objetivo de mostrar a inexistência de crenças legítimas do povo brasileiro convergiu com o momento político insurgente e com a revolução teatral "oficineira". Consequentemente, conforme sabemos e certifica Silva (1981, p. 55-56), ao explorar a obra de Chico Buarque, Zé Celso ajudou a realizar as alterações de Roda Viva, que chegaram até à reescrita de certas passagens, aumentando-se o texto, já não clássico, de uma para duas horas e meia: o espetáculo pôs o enredo em um estúdio de televisão, com numerosos artifícios visuais e compulsória participação da plateia como auditório, além de ter ampliado o coro (de quatro para treze atores) e suas atividades e incluído mais músicas e ritmos; ainda, na ocasião do suicídio do ídolo, adicionou-se a beatificação e a crucificação, bem como alargou-se a crítica à "esquerda festiva". 
De acordo com essas ideias, Zé Celso utilizou o texto de Roda Viva para criar a polêmica encenação, estruturando a linguagem e algumas escolhas cênicas já exploradas em 1967, tanto que, para alguns pesquisadores, mas não para ele mesmo, o encenador poderia ser considerado o coautor da peça, mesmo tendo contribuído posteriormente na sua feitura: conforme veremos mais detidamente na entrevista-manifesto do diretor, por meio das indicações do "teatro da crueldade", ele queria atingir politicamente a plateia de classe média e de esquerda, estremecendo suas concepções, atitudes e posições sociais, supostamente estáveis e paralisadas, para fazer com que essas pessoas saíssem de uma tóxica zona de conforto e olhassem para o estado real das coisas no país (RABELO, 1999, p. 39-41).

Desse modo, sabendo que apenas a leitura da peça não nos daria a proporção exata do significado de Roda Viva em sua época, podemos dispor dela para rever seus argumentos. Assim sendo, concernente ao texto, na presente sessão da pesquisa, retomaremos os pilares minuciosos do enredo, entremeados e seguidos por comentários de relevância no exame do espetáculo musical "desconstruído", no qual significados foram modificados e/ou agigantados pelo diretor, tendo em vista o reconhecimento da dramaturgia sutilmente rebelde de Chico Buarque como "roteiro" para a criação de Zé Celso - esta sim, causadora de real escândalo por promover uma nova e explosiva relação com o público, não mais visto como cúmplice. Portanto, levantaremos alguns elementos e trechos deste escrito, utilizado pelo encenador e digno de memória, fazendo o exercício, conforme realizamos para o Teatro de Arena, de associar componentes de Roda Viva ao engajamento que pensamos estar presente no Teatro Oficina em 1968. Complementarmente, faremos o aproveitamento da fortuna crítica de referência, bem como de materiais da imprensa, de críticas especializadas e de entrevistas concernentes à montagem.

Conhecida como uma comédia musical escrita em dois atos, Roda Viva não foi dividida em cenas, mas podemos fazê-lo em função das canções e das entradas de personagens expressivos. Em síntese, o enredo é simples e, mapeando a desmistificação de ídolos, como dizia o próprio autor, trata da problemática do interesse comercial da indústria da cultura através das rápidas ascensão (glória) e queda (esquecimento e morte) de um ídolo popular criado pela televisão, que era ligada à massificação cultural daqueles anos. Ele, Benedito Silva, sambista empresariado e assediado por um Anjo (com traços ambiciosos de manager, lucrando demasiadamente em cima do artista), alvo constante das armadilhas do Capeta da imprensa sensacionalista (mancomunado com o Anjo para ganhar a "sua parte" na 
venda da imagem do jovem $)^{22}$ e relapso com o seu casamento, é ingenuamente engolido e descartado pela encantadora roda viva do entretenimento. Em seu exitoso início, o cantor sem muito talento compulsoriamente vira Ben Silver, um ídolo pop de nome americanizado com multidões de fãs, que, porém, logo deve morrer, de forma simbólica, para descansar a imagem vendida pelos jornais (é visto como um bêbado), já não agradável ao público nem viável comercialmente. Renascendo como o cantor de protesto Benedito Lampião, um novo sucesso brasileiro, violento e nacionalista, ele chega até mesmo a cantar no exterior; na volta, no entanto, é rejeitado pelos seus admiradores (também os de esquerda) por ter ido agradar aos imperialistas e por ter-se descoberto sobre o seu casamento. Por fim, cedendo às pressões de marketing do Anjo e diante do fracasso da sua popularidade degradada, Benedito comete suicídio para se redimir. Com isso, Juliana, sua esposa, toma o seu lugar de mito na indústria cultural como o novo ídolo hippie e/ou tropicalista Juju, dando a entender que as manias são efêmeras e que a roda viva deve continuar girando. Assim, temos, desde o título, a sugestão de arremetida a um sistema implacável e destruidor de humanidades.

A abertura da peça, um prólogo onde o coro toma a frente da situação, é marcada pela total miséria do povo (de alimento e de democracia social, numa possível alusão à ditadura) através de uma espécie de procissão, cega por uma religião ou mito, que canta epicamente o que lhe falta, como se essa fé fosse a única saída. É imprescindível relembrar o fato de o coro não ter sido previsto dessa maneira no texto buarqueano, na prática, sendo acrescido para ocupar a cena com seus treze atores fazendo as vezes de todo o movimento coletivo da história. Nesse ínterim, o protagonista irrompe, cercado por câmeras de televisão e alimentando os demais com "pão e circo", pois substitui crenças ao entrar no programa de auditório: de maneira épica e, ao mesmo tempo, televisiva, envolvendo o público, ele, um homem bonito no espetáculo, se apresenta e empola o discurso cada vez mais, de forma egocêntrica, ação seguida por um apelo ao consumo realizado pelas garotas-propaganda sobre a plateia do teatro. Essa intervenção consta em uma rubrica do texto e pode ser encarada como a primeira "agressão física" do coro, ao que a crítica tanto fez referência, demonstrando a montagem um indício de engajamento crítico à burguesia, levado a cabo de maneira antropofágica pelas macacas de auditório:

\section{BENEDITO}

(Voltando para a câmera, empostando a voz, perdendo a naturalidade.)

\footnotetext{
${ }^{22}$ Como assumiremos durante a análise, o universo religioso é profanado já no texto de Roda Viva, mais diretamente na realização dessas duas figuras, Anjo e Capeta, que nada têm de divinas e desencadeiam, por vezes conjuntamente, ações importantes da trama, principalmente as maléficas.
} 


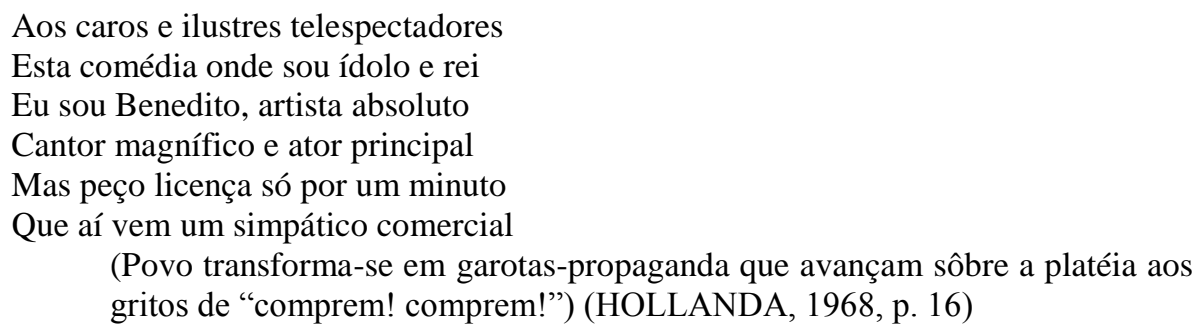

Fica claro que Roda Viva nos apresentará um processo de idolatria. Portanto, logo mais, temos a cena da paramentação, na qual o Anjo "molda" Benedito como um ídolo nacional e um produto: ele é despido por figurantes ao som de desfile e de fox. Com um terno prateado e militarizado (inteirado no período histórico), o novo estilo é agregador e eclético, mas há uma carência de personalidade no sujeito, manipulado pelas ações do empresário a fim de torná-lo célebre, vendê-lo e promover ideologias dominantes (algo não explícito). A própria linguagem já indica o aniquilamento do sujeito, que perde seus direitos, humanidades e autonomias para, progressivamente, tornar-se uma mercadoria rentável, atingindo multidões, em uma concepção cultural moderna. Não menos importante, é nessa sequência que o Anjo finge preocupação com o artista, lhe promete fama e dinheiro e reclama a sua parte de $20 \%$ nos lucros, circunstância questionada por Benedito, mas aceita inocentemente. Ainda, o empresário instiga o cantor a querer estar sempre na moda e acaba por dirigir-se epicamente à plateia, prescrevendo como deve ser um ídolo, diferentemente dos antigos artistas: uma imitação dos anteriores galãs americanos basta, visto que a cultura local é desvalorizada perante o surgimento de um mito ligado ao capitalismo.

No segundo momento, pela primeira vez, vemos Juliana, a esposa: o instante poderia se referir ao schwarziano encontro do universal com o particular, pois ela parece carregar o peso da tradição familiar e conjugal - inclusive, a rubrica informa que a moça faz tricô e ouve música caipira. Juntamente com Mané, figura a surgir na história, ela critica a metamorfose de Benedito e simboliza valores pessoais, como amor e amizade. Em cena, ela procura o marido e acaba conhecendo o Anjo, o qual demonstra intenções de modificar Benedito, algo não aprovado por ela. Duas coisas parecem ter mais importância nesse trecho: o índice de mudança do homem e o assédio velado (de aproximação física) em direção à Juliana, que insiste na valentia do marido para se defender, afinal ela é a "Juliana do Benedito". Sem acesso direto ao espetáculo original, acreditamos nessa passagem - quando Juliana se esquivava das investidas sexuais do Anjo - como exemplar da ocorrência de alusão profanadora entre a personagem e a Virgem Maria (malvista também por uma esquerda católica), dada muito em função das sugestões fálicas e das roupas aproximativas, 
pertencentes à indumentária religiosa, ainda a ser verificada em mais detalhes. Por fim e muito tranquilamente, o Anjo chega cada vez mais perto dela e se apresenta a todos, anunciando suas pretensões ao produzir um sucesso:

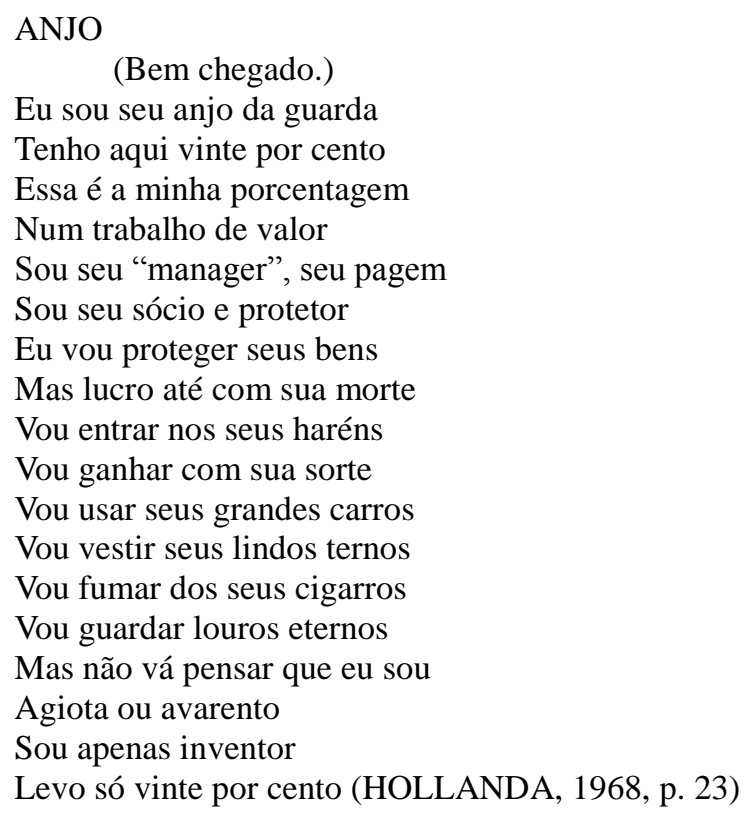

Em choque com as informações, Juliana tenta se afastar do empresário e, mais uma vez, clama por Benedito, que surge de maneira remodelada e sorri como se nada tivesse acontecido, sem se dar conta das modificações em sua vida particular - amostras disso são as relações estremecidas com a esposa e com o amigo Mané. Diante disso, o Anjo reage, misturando já pela segunda vez o Francês (item de eloquência e requinte) em sua fala e deixando o casal a sós; nesse momento, Juliana questiona o marido das intenções do empresário, inclusive sobre o assédio sofrido. Nesse caso, o que está sendo discutido pela peça e pelo espetáculo é a propriedade dentro da indústria cultural; logo, quem empresaria lucra, isto é, tudo pertenceria inegavelmente ao Anjo, o corpo da mulher e o dinheiro do artista. Ademais, ele também pertence, em termos de imagem, ao seu público. Frente à situação e afetado pelo deslumbre, Benedito não dá crédito à mulher e inocenta o vilão, agarrado ao mito da assexualidade de seu "chefe". Em seguida, Juliana demonstra repulsa ao novo jeito do marido, fazendo uma piada homofóbica (“cintilante feito bicha louca"), e ele, como já está transformado, repete a ação do outro personagem ao falar em línguas estrangeiras no meio do seu discurso, proferindo termos em inglês. Novamente, vemos que o preconceito à sexualidade não era uma preocupação dos artistas teatrais sessentistas, mesmo os mais conectados à realidade social, como vinha se demonstrando o Oficina.

Em nova tomada, Mané aparece no bar; por sua vez, o ritmo vai do samba ao chorinho 
cantado por Benedito, que encontra o amigo bêbado e anuncia um futuro individual de riqueza. Todavia, não sabemos se este é realmente o seu desejo ou se ele está somente sendo arrastado pela roda viva, seduzido e com ambições de ídolo. Ao final de sua exibição, ele se compara a Mané, depois ofende e magoa o amigo - esse personagem é um homem livre, apesar de o vermos sempre preso à sua mesa e à sua garrafa, pois não se vendeu:

\footnotetext{
Ô Mané, como é, não vai vibrar, babar de admiração? Pelo menos olha pra cima, que êste seu amigo resolveu vencer na vida! (Pausa) Mas o que é? Que é que você queria? Que eu ficasse aí vegetando a vida inteira feito você? Era só o que faltava! Continuar, por solidariedade eternamente bêbado, inútil, anônimo... Eu, hem? (Pausa). Que é que há, Mané? Diga alguma coisa! Afinal não é todo dia que um melhor amigo vira ídolo... assim de repente... prateado... pulseira... (HOLLANDA, 1968, p. 26)
}

Quando a conversa finda, Juliana ainda corre do Anjo, insistente nos assédios físicos e verbais, diante da inércia de Benedito, tratado como burro pelo empresário (ele explica grosseiramente o termo "eureka" ao cantor), que faz questão de lhe recomendar o uso do novo nome, Ben Silver, rejeitado por Juliana, mas excelente para a propaganda, segundo ele, "a alma do negócio”. Ben Silver é claramente um item do imperialismo americano, consumido por um país subdesenvolvido cultural, política e economicamente como o nosso (a chamada "periferia do capitalismo" descrita por Roberto Schwarz) - através disso, é enfatizada a crítica da peça ao período ditatorial brasileiro, durante o qual o regime era também alicerçado na invasão de capital americano. De maneira incisiva, talvez uma ironia do texto, o Anjo manda o seu agenciado crer e obedecer à televisão, como se esta fosse uma santidade (há uma reza coletiva à ela, em nova invocação religiosa), ensinando-lhe o bom comportamento na TV, controladora das massas: nisso, retomando a reza, ele faz analogias entre câmeras e serpentes, que podem pegar Benedito desprevenido, e reforça o agrado obrigatório à televisão como o objetivo último de um artista, mesmo sob fingimentos e aparências, tendo em vista a importância e o tamanho menores do público presente em comparação ao grande público atrás das lentes, a quem se deve servir a fim de atingir a glória, lugar fictício onde a voz e a arte não importam e a imagem é tudo.

No trecho seguinte, Benedito reflete acerca de seu novo nome e, estando a sós com Juliana, com quem sua relação desaba progressivamente, questiona-a, enquanto ela fica amedrontada pelos desdobramentos da tal mudança. Para amenizar a situação, ele diz querer ser chamado de (meu) Bem pela amada, que canta, romanticamente, Sem fantasia para ele. Ao final da cena de romance, um abraço do casal é separado pelo Povo (do coro), representando a impossibilidade de eles ficarem juntos. 
Logo, os parceiros Anjo e Capeta (personagens frequentemente associados para lucrar) adentram o centro da cena cantando uma marchinha e se vangloriando de serem contraditórios, relacionando si mesmos com o vigário e com Satanás - tal fato pode ser muito simbólico sobre a classe média brasileira, criticada pelo espetáculo, então bem relacionada com o governo e com a esquerda. Na mesma sequência, insinuando benefícios com a proximidade, o Anjo paga um dinheiro ao Capeta para este falar bem de Ben Silver: representando alegoricamente a imprensa (vista com maus olhos), ele o faz, e assim, o palco é tomado por uma multidão personificada pelo coro (parodiando as fãs da Jovem Guarda), antecipando a informação de que Ben Silver virará mania nacional. Entretanto, o empresário interrompe a bagunça para anunciar a presença do Ibope, uma espécie de "figura eclesiástica" e adorada, servidora da televisão a ser consultada para o sucesso. Como no caso do ídolo, esse personagem também tem relevância visual e, no espetáculo de 1968, foi interpretado por uma mulher ruiva e alta. Nesse instante, o coro canta o iê-iê-iê americano, e, além disso, há a apresentação do representante da TV pelo Anjo, em meio ao som. O ritmo musical, colocado aí, referencia a arte-mercadoria da forma mais cabal, visto que o iê-iê-iê era considerado pelo conjunto da MPB como algo não legitimamente brasileiro, mas superficial e para ser vendido - briga na qual os tropicalistas não tomaram posição definitiva, apenas "deglutindo" influências de ambos os lados.

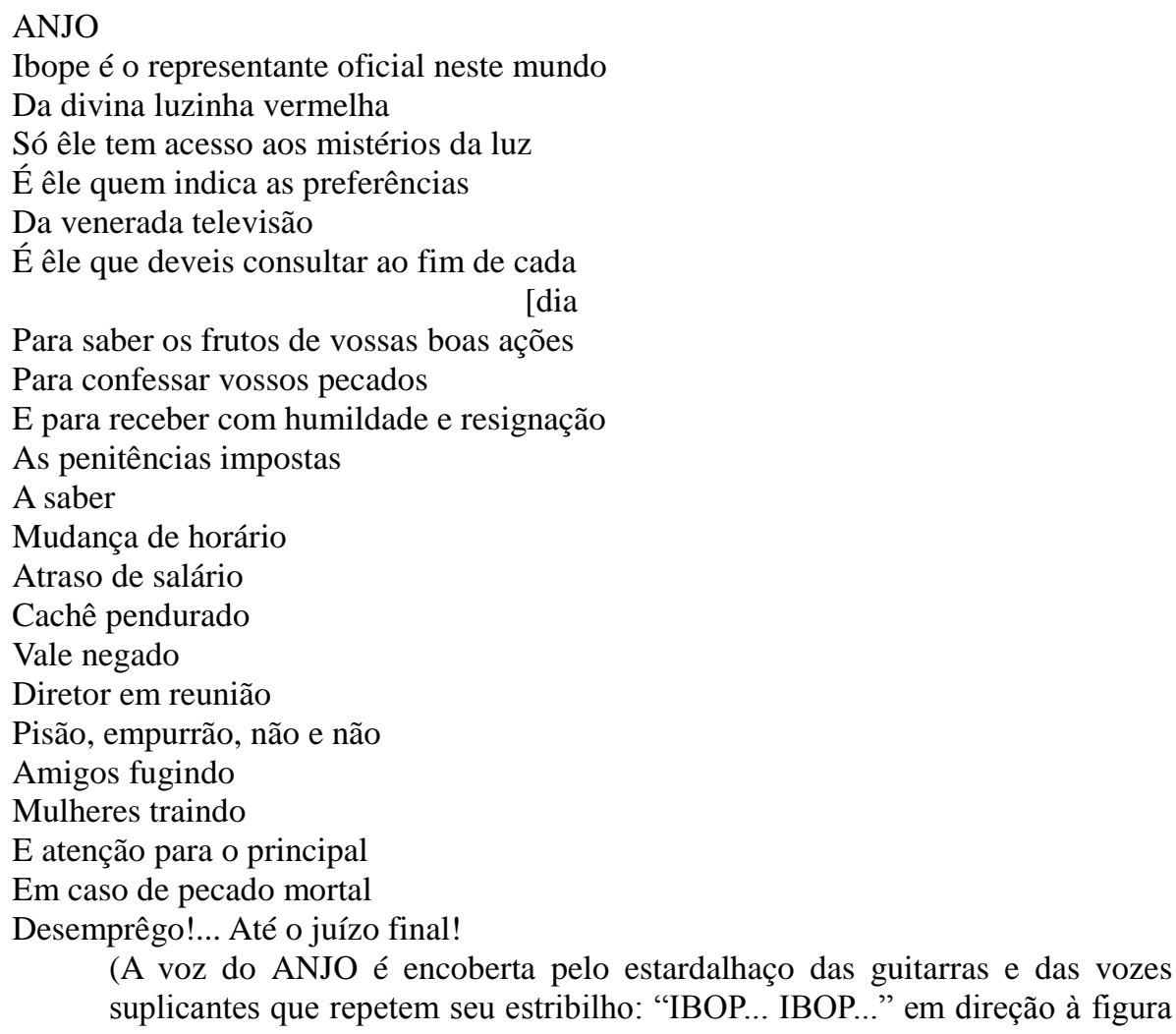


eclesiástica do IBOPE.) (HOLLANDA, 1968, p. 34)

Essa cena traduz muito bem a roda viva do entretenimento de massas, pois, diante do lançamento da maravilha do "novo ídolo", o Anjo substitui alguns artistas, "atirando-os" longe por vários motivos normalmente fúteis, como a idade. Afinal, os restantes competem pelo plano principal em frente às câmeras, e, como informa o texto, pela primeira vez na televisão brasileira, Ben Silver, é apresentado, entrando em cena coroado, nos braços do Povo e ao som do iê-iê-iê. Pode-se notar as alfinetadas do autor à Jovem Guarda (conjunto de artistas politicamente alienados), quando Ben canta paródias de dois sucessos contemporâneos à peça, Coração de papel e Era um garoto que como eu amava os Beatles e os Rolling Stones - o primeiro é de Sérgio Reis, e o segundo foi gravado por Os Incríveis. A renda disso é dividida entre o cantor, o Anjo, o Capeta e o Ibope, que cantam o Caxangá.

No final do ato, temos uma longa série de falas e cantorias de Benedito, que, extasiado, computa bens materiais e vantagens com a fama, primeiramente esquecendo-se de Juliana, uma vez que quer ter amantes; então, dará bebida para Mané e pão para o Povo, em mais uma referência a "pão e circo". Ademais, ele atira "restos" de dinheiro, como migalhas, para artistas inválidos e volta o fundo musical do Caxangá. Ainda refletindo sobre os ganhos, finalmente se lembra de Juliana, a quem dará anticoncepcionais para não ter herdeiros. Mais migalhas e mais solidão para Ben Silver. Logo, aparece Mané em seu cenário de bar junto ao som do frevo, o qual Benedito canta e dança, vangloriando-se de "felicidade" frente ao amigo, a quem ele oferece um autógrafo. A lucidez de Mané corta a música e as atitudes do ídolo com um seco palavrão - o personagem, cuja localização marginal e linguagem "imprópria" denotam sensação de não pertencimento, parece personificar a consciência do outro, característica controversa em relação ao fato de ele ser um bêbado. Porém, as fãs do Povo rodeiam o artista, inflando o seu ego novamente, depois, mendigos despem o seu corpo selvagemente (em tons de antropofagia) ao som da Macumba ritual do canto final: nele, o “feijão na nossa cuia" parece ser o próprio ídolo, esperança do Povo e "pão" que os alimenta, mas, por fim, jogado pelas macacas. A crítica é evidente: a sociedade brasileira (e nisso é incluído o desconfortável público) cria mitos para mascarar os problemas do povo, então, este povo "come" os ídolos fabricados e se sacia. Consequentemente, a selvageria é abruptamente sustada em termos de iluminação e sonoridade para o encerramento do ato.

O segundo ato, versando a respeito da roda viva delineada, tem início por meio de uma luz amena, posta sobre Juliana e Benedito, e uma declaração romântica (Sem Fantasia) cantada por este para a esposa, que o acompanha - a canção gira em torno da relação deles. 
Entretanto, a bonita cena é interrompida por câmera e música de TV: através de uma "Voz", o programa "O Artista na Intimidade" invade a privacidade de Benedito, que recompõe a sua pose de ídolo (uma imagem de Rei, em certa medida aproximada à de Roberto Carlos) e tenta camuflar Juliana, a quem o programa trata como sua mãe. Nesse instante, surge o Capeta da mídia desestabilizadora, dizendo saber de algo inédito: ele denuncia o fato de Ben Silver ser casado, situação não admitida pelas fãs (o Povo seria o seu dono), sendo o cantor visto com perfídia e desvalorizado enquanto produto. Após este rompante do Capeta, o Anjo intervém para dissimular e há uma sequência brilhante de texto entre os dois golpistas, em referência a mentiras enraizadas por trás da opinião pública: o empresário tenta desmentir a informação, afirmando que Juliana é a irmã do artista, e não a esposa, ainda oferecendo dinheiro por debaixo dos panos ao "fofoqueiro", que o explora até conseguir um pouco mais para, somente assim, espalhar a nova notícia. No fim, o Anjo dá uma lição no casal, pois gastou muito dinheiro com o descuido ou "brincadeira" deles.

No momento seguinte, Benedito, sempre seguido por olhares do Povo, encontra Mané em sua mesa de bar. $\mathrm{O}$ trecho referido expõe o metateatro: Benedito reclama da mudança do amigo, mas este responde estar do mesmo jeito desde o início da peça - em alusão à sua posição cênica e na vida, já que é "um Mané” -, sendo irônico, quebrando a ilusão teatral (epicamente) e pela primeira vez levantando-se para cantar:

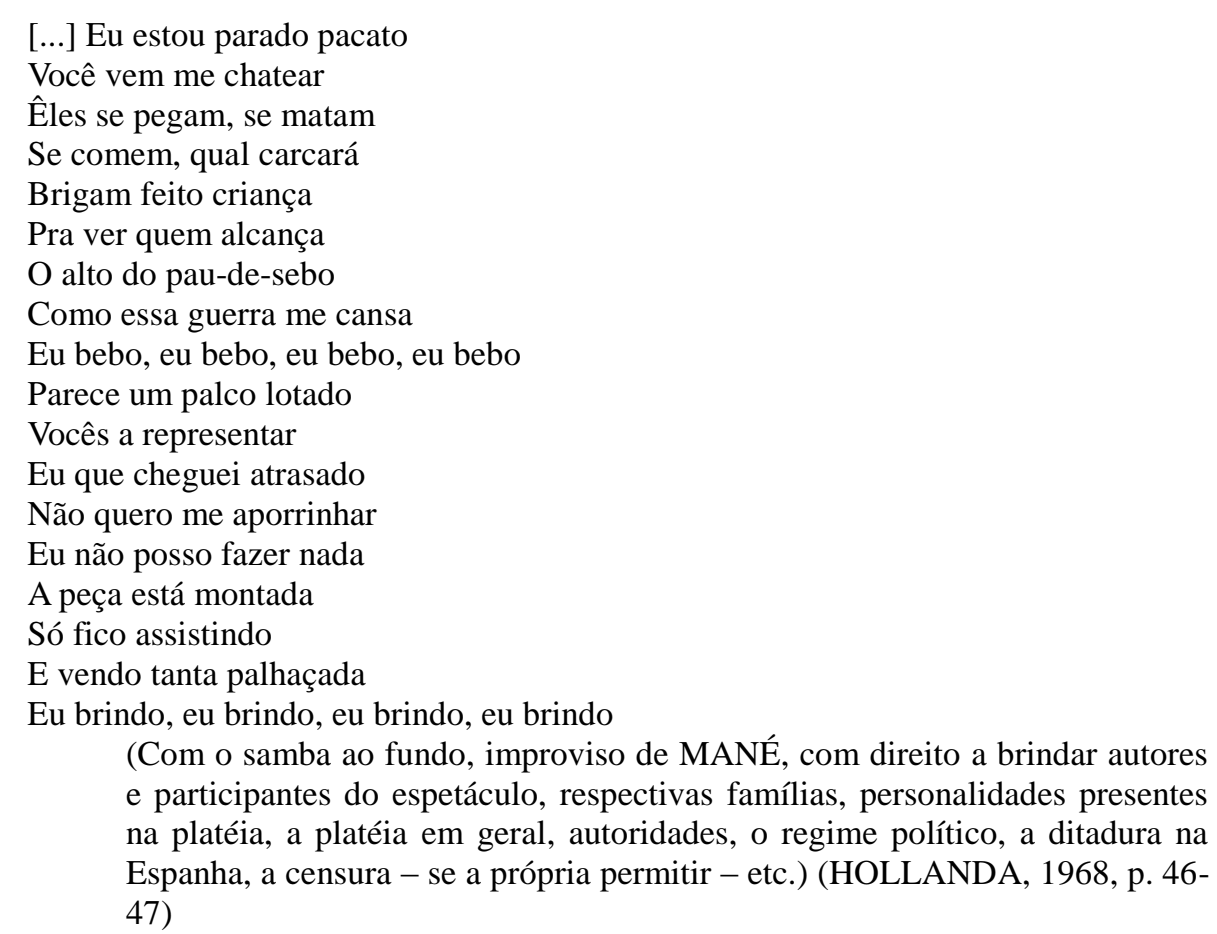

Nota-se que Benedito está conformado com a condição de ídolo, contudo, não sente 
fazer parte daquele universo. Representando seus momentâneos lapsos de lucidez, como dissemos, Mané recorda-o de como ele era antes de ser popular, apontando aquele velho militante político como o verdadeiro Benedito, e não a personagem criada e vendida pelo Anjo - isso igualmente dialoga com o período de estreia da montagem, de grandes agitações sociais. Após o desabafo do amigo, o cantor reflete acerca de ser ídolo do povo em uma série de falas intercaladas a palavrões e tiradas de Mané, possuidor de um vocabulário chulo já no texto, mais acentuado no espetáculo. Para Benedito, nada faz sentido; porém, a crítica da peça avulta novamente: a sociedade está desamparada e sem ter no que acreditar, à exceção dessas “coisas fabricadas pela mídia”; a esperança da população é o mito; há endeusamento em torno de si; e, por fim, ele sente um suposto e descontente arrependimento e uma vontade de parar de ser o ideal inalcançável.

Depois da reflexão e da falta de aprovação do companheiro, Benedito tem uma espécie de crise de consciência e declama desejos não ouvidos, calados por ele para continuar fazendo sucesso, chegando a contrapor a sua vida (de cantor regular, mas famoso de repente) à de um poeta brilhante, apesar de não aclamado pelo grande público - aqui, podemos afirmar que Chico Buarque retoma o lirismo de suas composições, presente em mais passagens da peça, como nas canções Sem fantasia e Roda Viva. Ainda, o personagem demonstra ter sido cooptado, como se fosse famoso sem querer ser, ou conduzido a sê-lo. Durante isso, o Povo canta Roda Viva ao fundo, marcando o impasse do momento e a ideia da maquinaria que nada perdoa, arrastando incessantemente para si a vida do artista. Este é o ponto alto do coro, junto à música-tema: à luz de Rabelo (1999, p. 31-33), a discussão da letra da canção nos mostra uma subjetividade anulada, em termos de renúncia, pela luta contra o dispositivo de massificação, representado pela temida roda viva presente no refrão, destruidora da "gente" diante do "mundo"; assim, a espontaneidade e os desejos são escamoteados (por exemplo, o destino, o samba, a viola, a roseira, a saudade) - os quatro versos iniciais das últimas três estrofes são os mais importantes para vermos isso; ademais, como os sonhos não são perseguidos, o sujeito, como um objeto, cai na armadilha, ação reafirmada a cada volta do refrão e nas acelerações de ritmo deste (corroboração também presente no vocabulário), o qual igualmente demonstra o consumo dos ditos sonhos e do tempo, um "agente deteriorador", e sinaliza a decadência da vida da "gente": ultrapassando a noção de sistema, roda viva seria a vida vivida em um mundo de provações, logo, o homem fica "como quem partiu ou morreu".

Com a música, os dois amigos bebem e conversam "felizes" sobre pessoas e acontecimentos do passado, não mais existentes diante da roda viva. Nesse encadeamento de assuntos, Benedito questiona Mané quanto ao Partido (Comunista), do qual ambos eram 
anteriormente membros, aparentemente aludindo à esquerda derrotada em 1964 - eles concluem que o Partido está falido, provocando parte da militância -; além disso, Mané acusa o outro de ter sido um "mau comunista" (assim como é então um mau amigo, mau marido, mau esquerdista, pois se vende à televisão, entre outras coisas). Ao final, os dois estão completamente bêbados, porém, mais conscientes, e cometem vários impropérios aos olhos públicos, tais como cantar, dançar e agredir o Povo - a agressão crítica do espetáculo, praticada sobretudo pelo coro, pode ser metaforizada através dessa passagem. As condutas são flagradas e registradas pelo Capeta, antevendo vantagens econômicas com a repercussão da "bomba" referente à queda do ídolo.

A sequência disso mostra a derrocada de Ben Silver, agora desdenhando de sua atual função. Há uma procissão coral de senhoras gordas, parecida com as Marchas da Família com Deus pela Liberdade (comuns na ditadura civil-militar), que canta, defendendo a caridade e a propriedade como valores morais, e denota o conservadorismo do tempo ditatorial, recusado pelo engajamento "oficineiro" - aqui, é fácil entrever as ácidas críticas de texto e cena à política e à religiosidade nocivas, setores interligados na época, em conformidade com o que comentamos no capítulo anterior. O Capeta, sem ficar para trás, espalha a notícia da "beberragem" do ídolo, adicionando o fato de que isso seria frequente. Benedito e Mané, por sua vez, caem de bêbados, rindo muito e sem pudores, e são julgados pelos olhares da procissão (o mesmo olhar da opinião pública e da constrangida plateia burguesa). Nesse momento, o Anjo novamente tenta amenizar a situação e a fofoca sobre a bebida, entretanto, como o artista está embriagado demais, suas ações fazem cair por terra a tentativa do empresário. Logo, temos um grande discurso do Anjo: “em off”, ele ofende Benedito, e, em público, faz promessas com o dinheiro do cantor para todos acreditarem em sua bondade:

\footnotetext{
ANJO

(Para BENEDITO.) Cala a bôca, animal! (Para o POVO.) O ídolo Ben Silver tem uma declaração ao povo e à imprensa em geral! O ídolo está empenhado numa vasta programação em benefício... (Para BENEDITO.) Larga do meu pé, imbecil! (Para o POVO.) Em benefício da velhice desamparada! (murmúrios.) Ainda no nobre intuito de colaborar com a sociedade... (BENEDITO e MANÉ derrubam o ANJO)... o ídolo destinará $20 \%$ de sua renda à construção de um orfanato! (murmúrios.) Mais $20 \%$ serão encaminhados a uma liga anti-alcoólica! (mais murmúrios.) Outros 20\% à liga das senhoras católicas! (alguns aplausos.) E 20\% à liga dos escoteiros! E 20\% para... para... 20\% para a Democracia!!! (O POVO explode em aplausos; as SENHORAS retiram-se bem satisfeitas, cantando em procissão; ANJO suspira aliviado, para BENEDITO.) Não é, Ben? (HOLLANDA, 1968, p. 58)
}

Ainda alcoolizado, Benedito faz algumas piadas, procurando o seu copo e, conforme se seguirá, querendo oferecer a sua ressaca ao Anjo, não somente o seu dinheiro. O Capeta, 
esperto ao presenciar o discurso, não se contém e explora mais uma vez o comparsa; em seguida, o traidor publica que Ben doará para a caridade os seus lucros, ou seja, ele propaga uma "fake news" patrocinada pelo próprio artista, por meio de seu empresário, com o fim de salvar a sua reputação. Finalizando o quadro, o Povo, representando possivelmente a classe média brasileira da década de 1960, repete os dizeres pela caridade e pela propriedade da procissão.

Estando Anjo, Benedito e Mané em cena, o primeiro reclama de prejuízo e continua ultrajando o cantor, este faz piada e o seu amigo segue proferindo palavrões e desconsiderando o agenciador. Além disso, o empresário tem uma ideia: por meio de novo uso da palavra "eureka" e de mais termos em francês ${ }^{23}$, muito didaticamente ele diz que Ben Silver precisa morrer, sendo isso uma solução de resguardo. Como produto, o ídolo está desgastado e deve dar lugar a um novo, proveniente da música popular brasileira - segundo a badalada "Time", esse gênero é o que haveria de melhor "para americano ver". Iniciando-se uma canção de baião, o Anjo planeja como será o novo item fabricado: ele faz alusões a cantores brasileiros (como Geraldo Vanderbilt, Chico Pedreiro e Maria Botânica, exemplos da comicidade de Chico Buarque em relação a si mesmo e aos seus célebres parceiros), ressalta o nacionalismo ("nacional da linha dura", "o mais nacional dos nacionais"), rotula e nomeia o artista como Benedito Lampião. Nisso, o coro surge como um bando de "agitadores", em referência à efervescência política do período, distribuindo enfaticamente gritos de revolução e panfletos na plateia e, em consequência, terminando contido por homens fardados - uma evidente e nova crítica ao regime militar, mas, também, à esquerda ineficaz. Por sua vez, Benedito reaparece como cantor de protesto, vestido de vaqueiro e cantando uma (falsa e populista) história de lutas, parodiando o sucesso Disparada e sendo muito aplaudido, já identificado ao povo - mais um traço cômico do autor, que, com A Banda, dividiu o prêmio de um dos festivais com a música de Vandré. Ao final, o palco é invadido pelo coro, simbolizando o público dos festivais da canção, onde as músicas de protesto eram aclamadas por serem politicamente representativas.

A cena de manifestação e celebração da sequência acima é um gancho para entendermos o que estava se passando naquele 1968 (ano de plena potência da ditadura), como determinadas parcelas da classe média achavam o ambiente ofensivo e o quanto esses tipos de ação da esquerda festiva (com um mercado de arte) ou da guerrilheira (ligada ao

\footnotetext{
${ }^{23}$ Nesse momento, o personagem diz "Le Roi est mort, Vive le Roi”!, uma conclamação comum em alguns países europeus no que tange à morte de um rei seguida pela admissão imediata de outro. Tal frase já foi bastante estampada na literatura francesa.
} 
movimento estudantil) eram fracos perante o Estado - fato "jogado na cara" do espectador, fosse o burguês insatisfeito e confortável, fosse o esquerdista tradicional "de sarau". Dessa forma, nota-se que o tema mais geral levantado pela peça, a atividade cruel da indústria cultural de massas, não foi exatamente a principal discussão do político espetáculo, que acusou o autoritarismo do período, bem como a falta de reação. O próprio Zé Celso constatou em entrevistas os graus de crítica do texto, mais grotesca, e do espetáculo, mais política; contudo, sempre expressou curiosidade pelo mito buarqueano, o qual deu margem a inúmeras leituras, nisso residindo a atração da peça, que, apesar de não esboçar uma ideologia, um raciocínio ou um engajamento mais apriorístico, é uma "tragi-comédia-orgia" rica em tomada de posição contra alguma coisa.

Retomando as rédeas da situação após o breve "ataque", o Anjo chama Benedito de Ben Silver, prontamente corrigindo o erro e anunciando-lhe uma proposta, supostamente ótima, de apresentação em Nova Iorque, nos Estados Unidos, o berço do imperialismo e da cultura de massas. Transformado em ídolo nacional e nacionalista (cheio de títulos cafonas), o cantor não compreende a viagem, mas o empresário garante-lhe que a entrada no mercado americano seria de muito mais valor, não sem antes mesclar novamente o francês em suas falas. Finalmente, Juliana é chamada e aparece de burro de carga, carregando malas; ainda, surge o Capeta, repelido pelo Anjo de forma esnobe; antes de sair com o casal, o empresário previne que o artista só dará coletivas internacionais, afirmando o estrelismo do astro, ambição frente à qual o Capeta promete "fazer o diabo", ameaçando se vingar. No palco, o Povo se divide entre quem irá apoiar, porque o mercado externo parece afastar o seu ídolo.

Sem demora, tem início o processo de vitimização de Benedito. Com luzes em cantos opostos e entre aplausos e vaias, o evento se resume a um confronto verbal baseado em notícias sobre a estadia de Benedito Lampião em Nova Iorque, ora lidas pelo Anjo (ele enfatiza o sucesso e as repercussões nos EUA, como o convite para tocar na Casa Branca), ora dadas pelo Capeta (ele acusa o entreguismo, a traição, o casamento e uma suposta homossexualidade), que pede mais escárnio - é o maniqueísmo puro aos olhos de todos. Assim sendo, o ícone é festejado em um lugar e visto como traidor em seu próprio país, tudo por conta de "fake news" (então negativas, com o propósito de arruiná-lo) e de ressentimentos do representante da mídia. Mais uma vez, o Anjo tenta dissipar a confusão: adotando a perspectiva do lado diabólico, o Povo renega o cantor, em sua volta, com vaias e objetos jogados contra ele (o gay vendido), embora o empresário tente acalmar a todos. Imediatamente, esses rompimentos fazem menção à realidade do país, pois, além da proximidade com os festivais na ocorrência da rejeição, a plateia passa a receber abaixo- 
assinados de estudantes, também feitos pelo coro, para que se defenda Benedito, ato interrompido por nova violência policial e muitas prisões - o trecho outra vez personifica uma esquerda impotente. Por fim, Benedito, Juliana, Mané e o Anjo permanecem em cena e tentam achar uma saída.

O desfecho da história ocorre a partir da tentativa de salvar o nome do artista, difamado em sua volta ao Brasil. No entanto, o Anjo enfatiza a sua nulidade igualmente para o público americano (sendo "laranja chupada" por lá); portanto, pondera-se a melhor opção diante da nova crise: fazê-lo morrer de verdade, como forma de expiação - pela primeira vez, ele estaria fazendo algo honestamente. Sem parecer impactado (ao menos no texto), Benedito consulta primeiramente Juliana, que chora, sendo este o seu "papel" nessa demagogia, segundo diz o Anjo, e depois, Mané, que solta um palavrão sincero, mostrando não se importar mais. O empresário, todavia, se interessa muito pela solução e, absurdamente, projeta maneiras de matar o ídolo decadente, concluindo que uma crucificação seria o bom caminho. Benedito discorda, com medo, argumento contraposto a uma série de outros do Anjo, como a necessidade de um mártir para o Povo.

Logo, o cantor se despede do amigo, já frio, e da esposa, a qual carinhosamente o chama de "Benedictus", potencializando a mitificação da sua figura. Ato contínuo, os personagens cantam uma ópera de despedida como fechamento da ação: Mané está decepcionado; Juliana está triste e o defende; o Capeta o acusa; e, enfim, Benedito parafraseia D. Pedro I (em uma ironia do texto ao "Dia do Fico") para o Povo, que repetidamente chama a sua morte:

\section{BENEDITO}

Como é para o bem de todos e felicidade [geral da nação.

Digo ao povo que morro

POVO

Que morra, que morra, que moorra

Que morra, que morra, que moorra

(Rufar de tambor; BENEDITO toma a direção de um automóvel; estrondo; BENEDITO cai fulminado; música religiosa.)

POVO

Aleluia

(Cantando.)

Foi-se o feijão da nossa cuia

Foi por nós um sacrifício

Ossos do ofício

Aleluuuuuia.

(O POVO amontoa-se sôbre o corpo de BENEDITO para devorá-lo.) (HOLLANDA, 1968, p. 72-73) 
Sendo apenas sugerida no texto, porém, aparecendo na encenação, a morte trágica do mito é efetuada através de um acidente não acidental, mas mirabolante: ele se joga na frente de um carro para ser atropelado, causando um estrondo que dá início a uma música religiosa. O Povo, tal como no início, cantando, lamenta a inexistência do "feijão da nossa cuia", considerando, entretanto, a morte do ídolo um mal necessário. O quadro termina com o Povo (a quem ele sempre pertenceu) em cima do corpo, devorando-o de forma canibal. O elemento antropofágico exposto remonta a $O$ Rei da Vela, espetáculo precedente do grupo de Zé Celso e primeiro exemplar do teatro ligado simultaneamente à realidade social, às vanguardas e ao recente Tropicalismo, como é sabido.

Por sua vez, o Anjo canta para Juliana, fazendo dela o novo produto na roda viva da cultura de massas, a qual deve continuar alimentando o Povo. Ela lhe dá um beijo, aceitando e mudando o seu posicionamento anterior, pois acaba de ser cooptada pelo sistema: "E assim a roda-viva do sucesso e da fama massificados vai esmagando ilusões e vaidades, enriquecendo alguns mais espertos, empregando matéria humana como combustível, mantendo a grande maioria em estado de ignorância e miséria." (RABELO, 1999, p. 37). Finalmente, todos estão no palco: o Capeta anuncia as duas notícias, a da morte de Benedito, ainda citado, e a da ascensão da viúva, chamada de Juju - ela é paramentada como uma novidade hippie e é carregada pelo Povo já como uma estrela. Por fim, sem a presença de Benedito e agora sem Mané (o amigo nunca concordou com os absurdos dos acontecimentos, apesar de viver "anestesiado" pela bebida), os restantes cantam respondendo com flores, um símbolo de renovação, mas, também, uma outra provocação à "esquerda festiva". Além disso, antes de jogar as flores ao público, quebra-se a quarta parede de maneira mais enfática (no texto, visto que no espetáculo, isso acontece constantemente): nesse trecho final, pede-se que quem não tenha gostado da peça fale mal dela. Quanto à última música, Rabelo (1999, p. 37) aponta a existência de duas estrofes "relacionadas ao plano ideológico da época", cheio de "dicotomias irreconciliáveis": na primeira, recorre-se ao mundo hippie e de tendências não politizadas; depois, às correntes mais engajadas em conflitos, e, por último, em um desenlace formalmente épico, conforme foi dito, refere-se ao próprio espetáculo, sendo convidativo à plateia.

Isto posto, ao denunciar os malefícios da indústria da cultura, na qual vários artistas populares sessentistas eram inseridos e mitificados sem realmente quererem, a peça resgata a problemática das classes mais pobres em uma época politicamente tumultuada pela opressão política e por valores morais dominantes. Assim, expõe-se a pobreza material (em analogia à cultural) levando o Povo à alienação em suas crenças, tudo por meio do culto de um mero ídolo fabricado pela manipuladora cultura imperialista, filiada às comunicações e ao regime 
ditatorial, o que preencheria o lugar de reais lideranças. Com uma linguagem atrelada ao mundo religioso, esta é a religiosidade moderna de Roda Viva, pela qual o enredo propõe desvendar a idolatria arquitetada pelas mídias. O cantor, por seu lado, colocado entre fanatismos e revoltas, sofre a cooptação da indústria agenciada pela televisão e a substituição nesse vicioso sistema, tendo no seu contraponto o sambista "de verdade", Mané (não rendido ao universo descortinado), e vai perdendo subjetividade e autonomia por não poder mais comandar a própria vida. A presente leitura, portanto, pretendeu dar amostras de como o contexto apresentado era muito sintomático do momento histórico de desolação e radicalização política de 1968 , sendo a roda viva uma representação do que seria a vida diante deste mundo.

Também, é interessante atrelar à análise um trecho da entrevista presente no folhetoprograma do espetáculo, no qual, posicionando-se contra a censura e a televisão, que incentivava o consumo de padrões prontos e não a divulgação cultural, Zé Celso define as novas urgências do teatro e delineia as intenções de Roda Viva:

Hoje em dia somente fazem sucesso as peças que tenham um sentido de choque cultural - Com TV à tôda, a única função do teatro será a de auto penetração coletiva e discussões de nossas mitologias mais recalcadas e profundas, de nossas neuroses coletivas - e são muitas!!! O teatro tem que exercer sua função de diálogo cara a cara com o público - e é êste encontro que nós brasileiros de classe média nos furtamos a todo momento: que se tem de acontecer que aconteça no teatro.

[...] Mas no Brasil onde existe todo um esquema de necessidade de revolução social e política a TV como se estrutura hoje é um ópio do povo. É neste sentido que ela aparece em "Roda Viva" - e ela passa a canalizar para seu universo de conformismo, tôdas as revoltas latentes. Assim no primeiro ato, todo o sentido religioso da TV fornecendo meios de satisfazer misticamente todo o anseio de consumo do povo que não poderá consumir: Ben Silver - o ídolo de prata. O ídolo é devorado e idolatrado enquanto representa aquêle membro da comunidade que consome mais que todos. No segundo ato a fossa do ídolo, o drama do ídolo vendido e alimenta tôda a "fossinha nacional", finalmente sua revolta política é logo canalizada para a festividade, para a bossa "Poder Jovem", para a grandiloquência de sê-lo comemorativo à TV, capitaliza e vende a imagem bossinha e esquerdinha do ídolo, até vender a sua morte. O espetáculo termina com mais uma mistificação. O "hippie" apalhaçado, importado, o culto da margarida e terminado o espetáculo - Programa de TV - tudo volta ao seu lugar, nada se passa - a banda passa - e tudo continua na mesma, muito barulho por nada. (BUARQUE; CORRÊA, 1968)

E em 1968 mesmo, após as repercussões:

Seu objetivo é mostrar tudo o que os meios de comunicação de massa utilizam, numa sociedade repressiva, para manter o cidadão distraído. Tudo o que aparece eles logo fagocitam, transformam, neutralizam, abstratizam e cospem a versão minorada e mixuruca da meia-satisfação. Rock and roll. Protesto político. Poder jovem. Etc. E depois de tudo, se vê a banda passar... (MARTINEZ CORRÊA, 1998, p. 120) 
Ao observarmos a obra em termos espaciais e temporais, vemos o seu desenvolvimento majoritário em um estúdio de televisão, algo público que adentraria a privacidade das casas dos espectadores. Para viabilizar isso no inovador espetáculo, segundo mencionamos, fez-se a mistura de palco e plateia dentro da ficcionalização de premeditados mau gosto e mal-estar, sem delimitação de espaço para os atores, que quebraram (e muito!) a “quarta parede". É interessante observar que no Rio de Janeiro, lugar da estreia, a montagem foi concebida em um palco do tipo italiano, sendo ressignificada e mais atrelada aos seus intuitos originais agressivos e de ocupação dos espaços em São Paulo, até porque coincidiu com a época das manifestações de rua.

Falemos especificamente a respeito do trabalho de Flávio Império na cenografia e na indumentária de Roda Viva. Apreciando o seu site, pode-se dizer que as notas agressivas da direção contagiaram estes aspectos estéticos, pois, apesar do estilo italiano de palco, é notável o fato de o artista ter adotado a indeterminação entre palco e plateia como um dos seus princípios de criação, na qual o público experienciaria fisicamente a peça, semelhante a um personagem, já que várias ações se passariam no espaço total da sala, como em uma roda. Reunindo, conforme vimos, uma atmosfera ao mesmo tempo sacra e de estúdio de televisão, uma passarela saída do palco (o "palco-televisão", um altar dos protagonistas), uma composição de coro que lembrava o candomblé, projeções de slide nas paredes internas do teatro formando um círculo ritualístico, um São Jorge e uma grande Coca-Cola marcando cada lado da cena, o "pequeno mundo" de Mané em sua mesa de bar (de onde ele podia assistir a tudo), três tempos e seus três ídolos explicitados em mudanças visuais (o ídolo pop e suas gola rolê e roupa prateada, o artista de protesto e sua cara de mau, debaixo de um chapéu de vaqueiro, e a estrela hippie de manto, como a Virgem Maria), entre outros elementos, Império confessou a sua aposta na intuição de Zé Celso para fazer Roda Viva em estrutura de missa, num catolicismo inverso, e confirmou certas finalidades politizadas, desbancando tabus com um "kitsch nacional":

Percorri então todo o baixo catolicismo carioca. [...] Juntei tudo isso a imagem de um Santo que achei sempre com cara de iê-iê-iê, que é o "Menino Jesus de Praga". Acho que porque ele tem sempre um manto todo prateado e uns grandes punhos ao redor da mão. Um microfone naquilo resolveria, na minha opinião, a imagem do santo glorificado por uma platéia que confunde muito gente com herói. Achei esse gancho. O Zé montou uma estrutura em cima da missa e começamos a trabalhar os intervalos que iam desde a coisa conservadora do pensamento brasileiro até aquilo que parece ser a coisa menos conservadora do pensamento brasileiro, a chamada vanguarda. Entre um e outro foi ficando caracterizada uma visão distante e crítica dos momentos de glória do cantor de rock, dos momentos de glória nordestinos, dos momentos de glória do cantor festivo, dos momentos de glória de todos os cantores e do processo de venda desses cantores que a televisão faz. Então o palco era a 
grande boca de cena de televisão. No alto, São Jorge e um vasinho com uma rosa bem grande, como se fosse uma coisa "pop" (estávamos no tempo dos "Lichtensteins") e do outro lado coloquei uma grande garrafa de Coca cola e o Pereio [Paulo César Pereio, o ator que interpretava Mané] sentado a uma mesinha que era o bar. A coisa aconteceu nesse universo que eu via como se fosse uma mesinha brasileira de canto de sala, que vai desde as saletas da favela até os salões, onde está situado o aparelho de televisão. Só que cada espectador se via refletido, de algum modo, no personagem que estava em cena. Foi uma leitura mais sociológica, digamos assim, que eu comecei a fazer em cima dos personagens, criando um imaginário simbólico para cada um. (IMPÉRIO, 1983, inclusão e grifos nossos)

Visto que ninguém ficava realmente nu, o figurino também compreendia desde um avental e asas escuras, utilizados pelo Anjo, malhas colantes aos corpos do coro, nas quais se podia desenhar esqueletos, e até uma boina e um livro do Mao Tsé-Tung para compor o Ibope.

O diretor, por sua vez, vendo a obra de autoria do cenógrafo e figurinista "santeiro" nascer junto à sua - de acordo com o andamento dos ensaios, na convergência das suas antropofagias -, fez questão de destacar os paramentos litúrgicos, o trabalho manual de Império e de sua equipe nos figurinos e a sacralidade e ritualidade da proposta, na qual as paramentações oferecidas aproximavam demais os personagens de santos e/ou mitos, com o coro vestindo e despindo o protagonista a ser devorado (ora carregado pelo Povo, ora despedaçado pelas fãs):

\footnotetext{
Os figurinos eram roupas rituais. [...] O Flávio fez figurinos rituais, de tal maneira que, no momento em que você entra em um deles, está incorporado. Ele desenvolveu essa história de paramentação de uma maneira muito especial e original, uma forma ritualística de criação que me lembra o Bispo do Rosário, curtida em cada detalhe por suas próprias mãos.

Quer dizer, Roda viva, foi, é uma revolução. Todo o meu trabalho a partir de então, se transformou radicalmente. (CORRÊA, 1983)
}

Ainda, frente à ausência de indícios de tempo, à presença da televisão, surgida na década de 1950 no Brasil, e aos artistas e canções parodiados, costuma-se localizar o enredo no momento contemporâneo ao de escrita e montagem da peça, no final dos anos 60 . Ademais, formalmente, o texto registra a variação entre canto, verso e prosa, usos que evidenciam a não ocorrência de um só gênero dramático, mas que também complicam a nossa leitura tardia - à exceção das ações principais, é difícil saber com precisão quando um personagem canta, diz ou declama algo, e de modo similar, não havendo acesso ao espetáculo original de 1968, não se sabe ao certo o grau de adesão de Zé Celso às partituras de Chico Buarque, nas quais há algumas indicações sobre partes cantadas, e quais das rubricas presentes na edição da Sabiá são marcas da direção para o coro, incorporadas após a encenação. No que tange à forma, igualmente podemos assinalar uma inadequação ao realismo (afinal, vemos um Anjo e um 
Capeta em cena e há desobediência às convenções de tempo e de passagem entre espaços); assim, o emprego de disformidades se justificaria pela vontade de Chico de criticar a realidade corrente, expondo uma história com distanciamento - o recurso épico ${ }^{24}$ objetivando uma reflexão do destinatário, não a sua identificação, como é sabido (RABELO, 1999, p. 24).

Dando início efetivo às contribuições críticas disponíveis, selecionamos algumas referenciais para o cotejo a seguir. Debruçando-se sobre o texto de Roda Viva, Rabelo (1999, p. 23-24) expõe algumas considerações de importância a respeito dos gêneros, a saber: o pesquisador afirma que uma veia cômica dessa "comédia musical" se dá através de elementos da farsa e da comédia mais tradicional (por exemplo: expressões de Bem e Mal em personagens, como Anjo e Capeta; o anti-herói e a moça pura; jogos lexicais; movimentações intensas; conversas prosaicas; intertextos e diversificação de ritmos), havendo também ingredientes da tragédia (como o coro, que sublinha a história e é feito por Povo, músicos, imprensa e por Mané; as cenas rituais, mas profanadoras; e ainda, a situação de abrangência do artista por uma "superestrutura") e do drama burguês ("a crise de consciência" de um protagonista comum), concluindo-se pelo uso variado de gêneros teatrais, em um diálogo, desta vez do texto de Roda Viva, com o Teatro de Arena e o seu brechtianismo declarado.

Ligado a esse aspecto, é válido ressaltar o fato de a obra teatral buarqueana retratar criticamente a geração e a sociedade amordaçada presenciada pelo autor, sendo muito conectada ao seu tempo; logo, conforme Rabelo (1999, p. 23), Roda Viva precisa ser lida à luz de seu momento histórico, exibido tanto na dramaturgia contestadora quanto na encenação radical. Estudando a figura de Chico Buarque como dramaturgo, Rabelo (1999, p. 38) demonstra a origem do interesse geral por Roda Viva (um texto simples, início do compositor no teatro) dado pelo debate trazido pela obra sobre a cultura sessentista no pós-golpe: o ambiente dos festivais da canção, os ramos da música popular brasileira em eclosão e comercialização (a seção de protesto, a Jovem Guarda e o Tropicalismo), as versões críticas e paródicas de artistas e músicas conhecidas, o emprego de línguas estrangeiras no vocabulário para conotar "domínio cultural”, a presença de ideologias e lutas pela liberdade então calada, entre demais coisas. Nisso, uma das saídas para a expressão foi o uso do palavrão frequente, exposto na peça e amplificado no palco (dando liberdade de improviso ao ator, como vimos), prática que, para Rabelo (1999, p. 38-39), aliada à agressividade, era excessiva e justificável no teatro daquele momento de crise econômica e cultural, no qual havia demasiada "ira e

\footnotetext{
${ }^{24}$ Produzida ao final da década de 1960, Roda Viva, semelhantemente a Arena conta Zumbi e a Arena Conta Tiradentes, utilizou alguns tópicos épicos, indicando o desenvolvimento dos procedimentos de Brecht em nosso teatro, tais como: a não adoção do realismo, a crítica de situação (levando o espetáculo a uma crítica social), o distanciamento e a presença da música (RABELO, 1999, p. 38).
} 
contrariedade" da classe artística a respeito das políticas de extrema direita em voga e das liberdades oprimidas - dessa forma, dentro de uma sala e diante de uma plateia pertencente à mesma classe social que os artistas da cena, em sua maioria, o levante era irrestrito, embora pequeno, se pensarmos em termos de nação e o quanto essas atitudes eram isoladas, além de os protestos mais ousados e revoltosos serem barrados pela repressão, oficial ou não.

Como é hábito declarar, em $O$ Rei da Vela, as novidades diziam respeito ao desligamento, e mais, à mescla de experimentos cênicos já experienciados pelo Oficina, estética e ideologicamente (tais quais Brecht e Stanislavski), adicionando-se a isso "tradições antiliterárias" ou marginais nossas - no caso de a referência de gosto ser burguesa -, como o circo, a revista, o carnaval e a chanchada, entre outros, como foi dito anteriormente e segundo ilustra Silva (1981, p. 48; 158); assim, trabalhando sobretudo uma descolonização com "o deboche, a anarquia e uma certa irracionalidade", a companhia negou o teatro mais realista, o comercial e o musical politizado, distanciando-se do Arena, grupo que consolidava o importante Sistema Coringa em sua técnica e desenvolvia o pensamento crítico racional e político, ao passo que o Oficina encantava-se por "um novo filão para a cena brasileira", mais anárquico: igualmente aos olhos do pesquisador, portanto, Roda Viva fez parte de um processo de rompimento iniciado por Zé Celso em $O$ Rei da Vela e nela radicalizado, em forma e conteúdo.

Sendo o objetivo do Oficina sensibilizar politicamente e desconcertar o público (com ênfase na burguesia progressista, na qual havia forte presença esquerdista, isto é, basicamente a conhecida recepção do Arena, com a sua "esquerda festiva"), no sentido de tirá-lo do conforto e de vitimizações, Silva (1981, p. 158-159) também menciona a importante entrevista de Zé Celso, a ser visitada pelo presente trabalho, enfatizando a violência até então nunca vista de Roda Viva:

A agressão indireta e a anarquia da forma de $O$ Rei da Vela em Roda Viva atingiriam
o limite de um espetáculo dos mais violentos e desconcertantes que o teatro
brasileiro pôde testemunhar. José Celso, após a experiência com o texto de Oswald,
adquiriu a segurança de que necessitava para, com todo o rigor, mergulhar de corpo
e alma numa experiência artística, onde prevalecia uma anarquia total, a coragem
provocativa que rompia totalmente com o espaço tradicionalmente destinado à
ficção e invadia a platéia para agredi-la, de um modo contundente, no seu
comodismo mental e, por vezes, em sua segurança física. (SILVA, 1981, p. 160)

Uma das prováveis influências da época ao encenador, Artaud foi celebrado no início da década de 1960 e, conforme diz Silva (1981, p. 160), o seu irracionalismo, junto ao humanismo stanislavskiano e aos tópicos políticos e sociais brechtianos, criava um "triângulo" 
norteador ao teatro (europeu e brasileiro); porém, o Oficina talvez fosse mais artaudiano:

\begin{abstract}
A grande saída, segundo José Celso, estaria no rompimento com todas as teorias humanistas e filosóficas de caráter racionalista do Ocidente e, na procura, dentro do próprio ato da criatividade, de soluções imaginosas, para sair do marasmo em que viviam as classes médias brasileiras, aquelas que podiam freqüentar os teatros. (SILVA, 1981, p. 160-161)
\end{abstract}

Sabemos que, apesar de cultivar algumas sementes do Teatro da Crueldade (por exemplo: os momentos de ritual, como o da morte quase sagrada de Benedito, marcada por ritmos de religiões; as profanações religiosas; a antropofagia da devoração do fígado, símbolo do coração do ídolo; as cenas de paramentação; o espaço indeterminado, com as ações crescendo para o exterior do palco e compreendendo a plateia até fisicamente na história; e o uso do texto como roteiro para a encenação, de linguagem teatral autoral), Roda Viva não é um espetáculo artaudiano por excelência, mas, juntamente com Silva (1981, p. 161-163), podemos afirmar a antropofagia de seu diretor desde $O$ Rei da Vela, ao deglutir variadas estéticas, e, principalmente, ao modificar Artaud: questionando essa influência na agressão aparelhada por Zé Celso, fica indicado pelo pesquisador que a mistura espacial entre artistas e espectadores, tida como item de comunhão no teórico, foi o que proporcionou abertura para provocações morais, gesticulações obscenas, contatos físicos e agressões à recepção, tal como acontecia na cena da Nossa Senhora vestida de biquíni e rebolando diante da fálica televisão, em outras ações contendo sugestões sexuais (e de homossexualidade) e nas passagens exageradas em palavrões do personagem Mané.

Comentando o tópico da agressão, também à luz da famosa entrevista, Silva (1981, p. 163-165) destaca que fora a parte "moral e física", a peça seguia com a desconstrução estética de $O$ Rei da Vela, rompendo ainda mais os padrões de público e crítica: sem um estilo harmonioso e acabado, propriamente dito, a ênfase da montagem recaía nas saídas criativas e na geração de impacto; portanto, a aparente falta de rigor e preocupação com gestos (parecendo improvisados) e minúcias era intencional e constituía um desafio ao elenco, perante as ideias estéticas congeladas de quem o assistia, pois, desde o espetáculo anterior, enfrentando esses paradigmas com a realidade nacional e popular, os atores obtinham mais oportunidades de bom desempenho pela negação de regras do que pelo "mero domínio artesanal de interpretação".

Fixando impressões de maneira um pouco distinta em torno de Roda Viva, Costa (2016, p. 199) assevera que o diretor dispunha da matéria buarqueana e das influências de Artaud e Grotowski, podendo realizar uma montagem agregadora entre o texto-pretexto e a vanguarda 
vinda da Europa: do primeiro teórico, ele teria adotado a perspectiva do "teatro da crueldade", na qual a plateia seria frequentemente agredida pelo elenco, até mesmo no nível físico e com a inclusão de muitos palavrões; e do segundo, teria feito o aproveitamento da cena da Pietà, atingindo a profanação da religião católica; ainda, adicionando a antropofagia adquirida com Oswald de Andrade em $O$ Rei da Vela, ele mostrou bem a noção de canibalismo (através do fígado cru). Contudo, não concordamos com a pesquisadora no tocante aos materiais mobilizados pelo encenador, uma vez que ele não chegou a admitir um uso direto de Artaud em suas concepções, no máximo provocadoras, mas não teatro da crueldade em si.

Diferenciando autor e diretor ao focalizar os seus diferentes alvos e associações com o público, Costa (2016, p. 199-200) defende que o texto, cheio de símbolos, denota "um nítido grão de moralismo", objetivando, na verdade, reconstruir a conhecida história do artista vendido: na época, Chico Buarque confiava na viabilidade da "arte de resistência" (fora da esfera comercial), igualmente apurada em Zé Celso; como vimos na peça, esta possibilidade estaria personificada em Mané, o sambista "autêntico", não vendido à indústria e "consciência culpada" do amigo Benedito, este, um cantor (simpático ao autor) "desenraizado e sem convicções firmes", levado pelas circunstâncias mercantis e cuja vida desvendava a tese de Chico sobre cooptação. Por outro lado, o espetáculo depreciava a esquerda "festiva" e se relacionava com a neomarginalidade, sublinhando o viés moral e fazendo um arranjo entre este e a agressão - conforme Costa (2016, p. 200), que externa a sua crítica (supostamente preconceituosa) a Zé Celso ligada a tal aspecto, completando:

Moralismo porque, com a trajetória de enfrentamentos entre o personagem e o sistema atenuada pelos reiterados desafios lançados ao público (criando a sensação de "anarquia" criativa), foi acentuado o lado subjetivo do processo vivido por Benedito, o lado do "artista que se vende", diluindo-se em referências metafísicoalegóricas o lado do mecanismo que o "compra". José Celso, como ele mesmo explicou em sua histórica entrevista [a qual trataremos de pormenorizar adiante], tratou de identificar o público consumidor (a plateia) ao sistema produtor da mercadoria consumida - confusão que Chico Buarque jamais faria - e, à falta de disposição (política) para acentuar criticamente o material oferecido pelo texto, optou por atacar e responsabilizar por tudo o elo final e visível do processo, com a vantagem de contar com a sua presença física, ao alcance da mão. No texto, como vimos, o povo faminto, miserável, sem direitos políticos e entregue à alienação religiosa - que a plateia é cerimoniosamente convidada a representar - é apresentado como vítima do sistema. Tão manipulada quanto o ídolo-mercadoria que lhe é oferecido para consumo derivativo. Não tendo o espetáculo interesse em fazer uma crítica mais elaborada sobre o sistema que lhe deu vida, restringe-se a contar uma história com pretensões edificantes, agredindo o público, previamente culpado pela própria alienação. Daí a profusão de símbolos católicos "profanados" com ousadia discutível, cenas que despertam reações de repugnância, como a devoração de um fígado cru, e até mesmo agressões físicas como sentar no colo de espectadores, sujar suas roupas etc., num comportamento regressivo [...], dependendo da forma de sua reação [do público], o andamento do espetáculo. (COSTA, 2016, p. 200-201, inclusões e grifos nossos) 
Portanto, tendo em vista as diferenças de vínculo com o público entre dramaturgia e encenação, fica sugerido o que o diretor fez da sua plateia: em vez de identificá-la com o povo manipulado vítima do sistema, promoveu a implicação desta ao sistema aniquilador e a sua culpabilização. Como reação, Costa (2016, p. 201), diz ter havido previsibilidade - no geral, tinha-se uma "adesão masoquista à proposta", em identificação ao agressor, ou "a rejeição total”, com as pessoas saindo do teatro -; porém, como também vai apontar Roberto Schwarz (1978), a participação ambicionada pelo texto, envolvendo todos no abaixo-assinado e na passeata, foi impedida pelas agressões e, no limite, impossibilitada - motivos a serem discutidos à luz de Anatol Rosenfeld (1996).

Desse jeito, debruçando-se sobre a arte comercializada, algo atual em 1968, uma era de debates em torno do mercado cultural (do qual o próprio Oficina não ficou de fora, realizando "teatrão"), Roda Viva quis atingir o poderio das comunicações de massa, gritando com o consumidor deste processo. É importante relembrar que o espectador de montagens como O Rei da Vela e Roda Viva era de classe média e de esquerda, equivalente ao do Arena, considerando-se, ao menos até 1967, o Oficina do mesmo lado; todavia, depois, já em 1968, a recepção burguesa começou a se afastar mais do que a aderir a esse novo tipo de protesto do teatral, anteriormente poderoso com sua crítica incisiva.

Explicando sua hipótese, Costa (2016, p. 202-203) enuncia que, após a responsabilização da classe média (supostamente conformista e à qual boa parte da esquerda detonada em $O$ Rei da Vela também pertencia) pela situação política, Zé Celso investiu na desmistificação de ideias como a de que essa classe seria vítima do imperialismo, das classes mais altas e/ou da ditadura, tendo ela de passar por "um tratamento de choque" para sair de dentro da sua bolha alienante e conservadora de mitos - outra observação feita através da entrevista-manifesto:

De acordo com a 'nova' teoria política adotada pelo diretor, esses mitos, todos forjados pela esquerda (herdeira do pensamento racionalista), além de servirem como justificativa ideológica para a inércia geral, impedem que todos vejam as verdadeiras causas de seus medos e de sua "petrificação". (COSTA, 2016, p. 202)

Assim, Costa (2016, p. 203) conclui pela inexistência de tendências prontas para encaixarmos os objetivos do líder do Oficina, nem mesmo a do teatro crueldade, pois o teatro "novo" deveria ser "cruel, anárquico e grosso"; fora isso, a implantação da dita agressão seria compreensível, já que Zé Celso sabia dos limites da reação da plateia aos seus ataques. 
Então, mesmo reconhecendo a força da agressão, Costa (2016, p. 203) afirma a imprescindibilidade da desmistificação no espetáculo Roda Viva, de cujo texto foi retirada a proposição (moralista), indo além: sendo a religião "a mais fértil fábrica de mitos", um público médio (sobretudo católico) seria desmistificado a partir da profanação religiosa; no entanto, se a dramaturgia somente expôs certos elementos religiosos e insinuou relações entre instituições e fé (como, por exemplo, a aparição do Ibope em forma de bispo e a visita do Anjo à Juliana, que, igual à Maria, o recebe para falar do "salvador"), por meio de armas de convencimento e verdades em comum, a sua montagem foi herege e blasfemadora, tendo forjado audácias ante a temerosa plateia, crente na simbologia ali desmoralizada. Contudo, não é forçoso encontrar algumas dessas indicações profanadoras no texto, sendo mais acertado dizer que elas foram ampliadas em cena com vistas à defrontação com o público presente.

Já Ventura (2008, p. 85-86) recupera o significado de Roda Viva na carreira de Chico Buarque, que, como comentamos, alvoroçou a "chicolatria" ao aliar-se intencionalmente a um iminente "mau comportamento" revolucionário; aliás, a canção Roda Viva, música-título da polêmica peça, com a qual ele havia tirado o terceiro lugar no III Festival de Música da TV Excelsior, em 1967, antecipava a pequenez do artista envolvido pelo poder aniquilador da indústria cultural, feita para um novo tipo de consumo - adiantado e insatisfatório na canção, o tema foi potencializado e, em nossa opinião, teve a sua sisudez carnavalizada "na mais inconveniente, exasperante e agressiva expressão teatral do ano" pela audácia de Zé Celso. Entretanto, o jornalista vê um movimento curioso, levando em consideração que o diretor, antes, tinha se aproveitado da anarquia de Oswald para a sua subversão e, depois, foi abastecer com a sua virulência uma obra aparentemente sem raiva, contando com o aval do autor a respeito da atuação em cima do escrito; apesar disso, a polêmica inicial foi justamente sobre o grau das contribuições a mais no espetáculo: certas opiniões afirmavam que Zé Celso havia modificado a obra de Chico, distanciada dele próprio, outras, que ele agregava valor ao texto substancial (VENTURA, 2008, p. 86-89).

Entre as cogitações de Ventura (2008, p. 87-88) referentes a Roda Viva, são destacáveis as nuances de Tropicalismo dentro da austeridade do período; também, temos o impacto de denúncia da peça relativamente à época de ouro da televisão; e ainda, musicalmente, ao usar estilos do momento, como "iê-iê-iês, paródias de ópera, canções de protesto e dois sambas sérios", além da tropicália, sugerida por estar na moda, o comportado enredo virou revolucionário no palco e deu ensejo a uma importante primeira "explosão visual, sonora e gestual" do nosso teatro, que, por esse tempo, conhecia o Teatro da Agressão - de 
ataques ao espectador e às formas estéticas e artísticas precedentes e esquerdistas.

Anteriormente, informamos do enorme sucesso dessa "loucura" provocadora de reações, até porque muitos ficaram curiosos (tanto pelo fato de o autor ser Chico Buarque, quanto pela montagem avassaladora); por outro lado, dissemos que parte da audiência teatral passou a ter receio de frequentar certas salas, assim como a crítica, ligeiramente atenta para os perigos de um teatro esteticamente libertário - talvez por isso não tenhamos muitas críticas especializadas sobre o espetáculo -, igual fez a esquerda mais racionalista, reafirmando a eficácia de afastamento objetivada pelo diretor (também questionada, conforme veremos, pois, supostamente, não houve retornos nivelados com a proposta) (SILVA, 1981, p. 57; 166).

A propósito, a crítica havia sido condescendente com $O$ Rei da Vela, mas, sem apresentar boas tolerância e compreensão, de certo modo, condenava Roda Viva, enquanto a recepção comum se fragmentava entre opostos, segundo Ventura (2008, p. 88-89): Zé Celso, radical dentro e fora dos palcos (quanto às suas falas), foi acusado de não se importar muito com o texto, o que era apenas a sua tendência de usá-lo como pretexto; ademais, ele alcançou o abono e a divisão almejadas no enorme público, atiçado por Chico, diante de um novo teatro detentor de metáfora e de agressão presentificadas - os artistas chacoalhavam tudo, crendo no debate político, e ocorriam diversas reações na plateia (inclusive violentas, já que o coro tocava provocativamente as pessoas). Logo, o êxito da montagem foi considerado uma solução da direção para a crise eterna do teatro:

Roda viva foi um sucesso de público, e num primeiro momento isso parecia provar
que José Celso não só encontrara a forma revolucionária de conscientizar pelo
choque, ou melhor, pela porrada, como descobrira comercialmente o filão
masoquista do público. Como há dois anos, pelo menos, vinha-se discutindo a crise
do teatro - sem se desconfiar que a discussão seria eterna -, estava ali a solução. O
espectador gostava de apanhar e estava disposto a pagar por isso. (VENTURA, 2008,
p. 90)

Segundo Ventura (2008, p. 90-91) - que percorre um impreterível ensaio de Anatol Rosenfeld, concordando com este -, embora o teatro fosse uma das mais fortes frentes de resistência ao regime político, ficando sob constante ameaça (no início não tão explícita) e crescente censura, as reações ou falta delas não melhoravam o quadro; de resto, a insurgência de traços violentamente irracionais do trabalho de Zé Celso poderia representar um risco, política e esteticamente.

É importante dizer que Rosenfeld (1996, p. 45-46) enfatiza o caráter violento e agressivo, cada vez mais aumentado, do teatro mundial e nacional contemporâneo a si: com relação ao público, isso se dá de maneira indireta, sobretudo verbalmente e do palco, como 
acontece em $O$ Rei da Vela, ou direta, mediante ações, barulhos e/ou comportamentos com a participação da plateia atacada, como vemos em Roda Viva, podendo-se misturar as duas formas. Concentrando-se sobre o fazer teatral de Zé Celso, Rosenfeld (1996, p. 46) o escolhe enquanto "expoente virulento" de um teatro agressivo no Brasil, abordando a entrevista histórica do diretor - já mencionada e da qual falaremos adiante -, em que este, explorando uma posição agressiva contra a audiência de $O$ Rei $d a$ Vela, se diferenciou dos artistas de esquerda, no geral. Assim sendo:

O teatro agressivo tem, de fato, a grande tradição do antitradicionalismo e antiacademicismo, típica da arte moderna, cujos movimentos vanguardeiros muitas vezes se distinguem pela revolta violenta. A ruptura com os padrões do "bom comportamento", do "bom gosto" e da "ordem consagrada" é traço essencial da maioria dos movimentos artísticos do nosso século, desde o futurismo, expressionismo e dadaísmo. (ROSENFELD, 1996, p. 47)

Tendo essas ideias em vista, Rosenfeld (1996, p. 50) tece considerações referentes a $O$ Rei da Vela e Roda Viva e alude novamente ao "manifesto-entrevista" para afirmar a possível preferência de Zé Celso por seguir Artaud (teatro da crueldade) em vez de Brecht (teatro épico), ao menos na época de tais montagens: pai de "uma forma original, bem brasileira de encenação" e menos racionalista, ele pleiteou "um teatro de crueldade brasileiro". Isto posto, Rosenfeld (1996, p. 50-51) traz as convicções do diretor do Oficina à tona para explicar o teatro agressivo, dizendo que o surgimento da "ira recalcada" carrega noções de justiça e sinceridade, além do possível "desejo quase religioso de catarse, de uma grande purgação coletiva", desnudando legitimamente a falsidade conformista do mundo, colocado perante realidades horríveis através de "recursos fortes" - o pesquisador chega a citar Eric Bentley, lembrando a subversão, o perigo e a anarquia envolvidos na arte cênica. À urgência da ira “oficineira”, Rosenfeld (1996, p. 51-52) relaciona ligeiras mudanças e crises, concernentes a sociedade e cultura, em seguida, parecendo defender um certo engajamento:

É dever dos intelectuais e artistas, cujas funções incluem a da crítica, analisar criticamente semelhantes contradições e, se necessário, manifestar a sua revolta em face delas. Cabe-lhes advertir e chamar a atenção sobre a necessidade urgente de adaptar, na medida do possível, a realidade aos valores oficialmente consagrados ( $\mathrm{p}$. ex., democracia, igualdade, liberdade) e quase sempre inscritos nas próprias constituições. É imperativo categórico, para o intelectual e artista, desmascarar a perversão semântica dos termos e o uso mistificador das idéias e dos ideais. Quando a tensão entre as metas e a realidade, entre a verdade e a retórica, entre a necessidade de transformações e a manutenção do status quo, entre a urgência da ação e o conformismo geral se torna demasiado dolorosa, são inevitáveis a "ira recalcada" e a violência das manifestações artísticas. (ROSENFELD, 1996, p. 52) 
Finalmente, em sua definição de Teatro Agressivo, Rosenfeld (1996, p. 55-56) expõe a sua crítica ao Oficina (ou ao menos ao que Zé Celso gostaria de fazer, pondo em debate a criatividade virulenta de Roda Viva), sem dizê-la diretamente, mas questionando toda a arte teatral em exercício em nosso panorama de caráter irracional crescente (ele não fala abertamente do encenador) e dialogando com Schwarz (1978), conforme distinguiremos: o teatro agressivo pode ser viável esteticamente e ter justificativas plausíveis para uns, contudo, isso não significa acatar o "seu valor geral" e a "sua eficácia necessária" de estremecimento de uma plateia conformada; ainda, admitindo o sucesso da violência ultimamente empregada, o ensaísta elogia Zé Celso, porém, desaprova o uso desta violência como "princípio supremo" - um hábito "contraditório e irracional" -, pois deveríamos tê-la apenas como componente estético:

\begin{abstract}
Contraditório porque uma violência que se esgota na "porrada" simbólica e que, por falta de verba, nem sequer se pode permitir o arremesso de numerosos violões, tendo de limitar-se ao lançamento de palavrões e gestos explosivos, é em si mesma, como princípio abstrato, perfeitamente inócua. Contraditório ainda porque a violência em si, tornada em princípio básico, acaba sendo mais um clichê confortável que cria hábitos e cuja força agressiva se esgota rapidamente. Para continuar eficaz - isto é, chocante - ela teria de crescer cada vez mais até chegar às vias de fato. Num happening desta ordem a companhia deve nutrir duas esperanças contraditórias: 1) (por razões de eficácia e orgulho profissional) a de que o público, vigorosamente provocado, responda com vigor e 2) (por razões financeiras) a de que haja um número bem maior de espectadores do que de atores, de modo que estes apanhem violentamente.

Além disso é completamente irracional uma violência que, desligada da "exatidão sociológica" e, possivelmente, da validade artística e da interpretação profunda da realidade, se apresenta como único critério da eficácia de uma peça. É irracional na medida em que é concebida apenas como explosão de "ira recalcada", sem ser posta a serviço da comunicação estética, incisiva e vigorosa, de valores positivos ou negativos, valores em conflito, valores criticados ou exaltados. A mera provocação, por si só, é sinal de impotência. É descarga gratuita e, sendo apenas descarga que se comunica ao público, chega a aliviá-lo e confirmá-lo no seu conformismo. O público burguês, de antemão informado pela crítica e pelos conhecidos, paga dinheiro para ser agredido e insultado e os gourmets em busca de pratos requintados adoram engolir sapos e jibóias, quando não há necessidade de esforço intelectual. Quanto à companhia teatral, fornece docilmente os insultos e sapos encomendados. Deste teatro neoculinário, que estabelece uma situação morna de conluio sadomasoquista, o público burguês acaba saindo sumamente satisfeito, agradavelmente esbofeteado, purificado de todos os complexos de culpa e convencido do seu generoso liberalismo e da sua tolerância democrática, já que não só permite, mas até sustenta um teatro que o agride (no íntimo, porém, sabe perfeitamente que um teatro que é provocação, apenas provocação e nada mais, não o atinge de verdade). (ROSENFELD, 1996, p. 56-57)
\end{abstract}

Portanto, acima, há um claro reconhecimento das qualidades inescusáveis do teatro “oficineiro" em um tempo de inações, mas, também, há inquietação do ensaísta em relação ao lado irracional da violência utilizada, uma vez que seria preciso fazê-la servir ao viés estético 
das obras. Sendo assim, poderíamos afirmar ser esta "ira recalcada" o diferencial do engajamento do grupo estudado, porque constituía a matéria-prima da revolução propagada o próprio diretor chegou a falar disso.

Todavia, discordando das irracionalidades, segundo já revelamos, em 1969, Zé Celso esclareceu as chamadas agressões (sentidas dessa forma por uma perspectiva específica) e indicou como origem do epíteto "Teatro de agressão" a mídia e antigos preconceitos:

\begin{abstract}
A expressão vem da imprensa, não é minha.... Eu nunca disse que pretendia agredir ninguém. O teatro, pela sua própria forma, é uma relação pessoal, como o diálogo, como o amor. O pequeno burguês que vê no teatro um meio de diversão tranqüilo, que prefere uma coisa tipo TBC é o espectador-tipo que vai se sentir agredido quando, durante um espetáculo, é obrigado a ter uma conversa de homem a homem. [...] O problema dos atores tocarem no público é uma coisa que, no meu entender, não tem nada demais. Não vejo qual o risco que corre uma pessoa ao ser tocada por outra. É apenas um preconceito. Um preconceito do século XIX e que numa sociedade futura deve acabar completamente. (MARTINEZ CORRÊA, 1998, p. 148)
\end{abstract}

Na mesma ocasião, noticiando um passado de simpatia pelo fascismo quando jovem, o encenador relativizou o seu radicalismo:

Quanto a ser radical, depende. Se ser radical é, como diz Oswald de Andrade, ir à
raiz das coisas, aí eu sou. Politicamente eu não tenho posiçoses radicais. As situações
são criadas e elas nos levam ou não ao radicalismo. Em arte, porém, é diferente.
Todo artista é um radical. O artista que compactua, que faz média, não faz nada. O
artista tem que se dar ao luxo de viver em revolução permanente. [...] Ele não pode
ser estático. Assim, eu sou um artista radical. (MARTINEZ CORRÊA, 1998, p. 150)

Do mesmo modo, durante uma entrevista retrospectiva, Zé Celso procurou afastar de si a conceituação de teatro agressivo e a qualidade de irracional (pertencente a uma impotência perante a realidade), corrigindo a crítica acadêmica clássica de Roberto Schwarz e de Anatol Rosenfeld, não conhecedores de linguagem corporal - no caso, as agressões visavam somente ao gosto do público; entretanto, como este era burguês e tradicional, Zé Celso automaticamente recebeu a fama de agressivo, negada por ele. Logo, haveria uma diferença de nível entre a autoimagem da peça (revolução cultural que desejava sim uma reação) e a compreensão crítica (produtora da pecha de irracional): localizando a existência, neste espetáculo, de uma violência revolucionária e legítima do que é novo no teatro, resultado de um movimento mundial de renovação, para o diretor, brutalidade violenta foi o que o elenco sofreu nos atentados já descritos, com o adendo de que, como rompia com o pensamento acadêmico e idealista, parte do esquerdismo da época deixou a companhia desamparada: 
Tudo o que vem de Roda viva é ligado ao coro, é ligado à idéia do coletivo, a toda uma linha de valorização do movimento de massa, da revolução cultural, da crítica ao stalinismo e fruto de toda uma linha pacifista por um novo tempo. Não tem a ver com violência para machucar, para ofender ou subjugar. Ao contrário, se é violenta, se foi violenta, era a violência do nascimento, do parto, da luta pela vida que ela colocava em cena. (MARTINEZ CORRÊA, 1998, p. 309)

Não habituado a separar forma e conteúdo ou teoria e prática, Zé Celso alega preferir ser visto como um artista dialético: pôr o corpo nas lutas políticas faz o indivíduo produzir um pensamento dialético. Então, "adornianamente", poderíamos dizer, ele entende que o privilégio do conteúdo faz parte do idealismo burguês, e ainda, que a esquerda clássica nunca superou a potência do inconsciente.

Já a respeito da agressividade da encenação, o diretor promove ligações com rituais de exaltação e leituras de Grotowski:

Eu tinha lido Grotowski. E o Grotowski diz que você sempre tem que fazer um trabalho de autopenetração: a personagem tem que penetrar em você, e você tem que exaltá-la para depois acabar com ela. Então nós fazíamos uma coisa exaltatória o tempo todo. Era uma peça cheia de Deus, religiosa mesmo. Era um auto religioso popular e orgiástico. Próximo de um carnaval, de uma macumba. E como foi um nascimento que veio da terra, foi considerado agressivo. Uma vitalidade excessiva brotou ali. Não cabia nos cânones do comportamento comum do público de teatro. (CORRÊA, 2012, p. 7)

Dando seguimento ao assunto, julgamos significativo considerar, mais uma vez, Schwarz (1978), que ensaia uma longa caracterização para o Teatro Oficina, distanciado do Teatro de Arena, anteriormente descrito com traços populistas:

Também à esquerda, mas nos antípodas do Arena, e ambíguo até a raiz do cabelo, desenvolvia-se o Teatro Oficina, dirigido por José Celso Martinez Corrêa. Se o Arena herdara da fase Goulart o impulso formal, o interesse pela luta de classes, pela revolução, e uma certa limitação populista, o Oficina ergueu-se a partir da experiência interior da desagregação burguesa em 64. Em seu palco esta desagregação repete-se ritualmente, em forma de ofensa. Os seus espetáculos fizeram história, escândalo e enorme sucesso em São Paulo e Rio, onde foram os mais marcantes dos últimos anos. Ligavam-se ao público pela brutalização, e não como o Arena, pela simpatia; e seu recurso principal é o choque profanador, e não o didatismo. A oposição no interior do teatro engajado não podia ser mais completa. Sumariamente, José Celso argumentaria da forma seguinte: se em 64 a pequena burguesia alinhou com a direita ou não resistiu, enquanto a grande se aliava ao imperialismo, todo consentimento entre palco e platéia é um erro ideológico e estético. É preciso massacrá-la. Ela, por outro lado, gosta de ser massacrada ou ver massacrar, e assegura ao Oficina o mais notável êxito comercial. É o problema deste teatro. (SCHWARZ, 1978, p. 85-86)

Referindo-se a métodos estéticos inovadores e a relações hostis com o público burguês, 
o professor resume bem o embate do período e a face do Oficina pós-revolução interna (um palco de esquerda questionável, como ficou definitivamente famoso), mostrando uma contradição: para Schwarz (1978, p. 86), ao negativar a sua audiência inteira, a companhia acabou entusiasmando estudantes, especialmente os não identificados com o populismo, que se sentiam mais próximos a quem agredia: "De fato, a hostilidade do Oficina era uma resposta radical, mais radical que a outra, à derrota de 64; mas não era uma resposta política." (SCHWARZ, 1978, p. 86). Contudo, tal asserção pode ser analisada como uma reflexão pessoal do autor, porque, conforme defendemos (e ele mesmo insinuará), as radicalidades “oficineiras" não deixaram de ser politizadas e de responderem à conjuntura ditatorial, apenas seguindo outra forma - se tomarmos como ponto de partida a esquerda artística paulista de 1967-1968. Assim sendo, entre atrasos e progressos, Schwarz (1978, p. 86) afirma o fato de a agressividade violenta do Oficina (legitimada pelas vanguardas internacionais) ter crescido com destino às "idéias e imagens usuais da classe média, os seus instintos e sua pessoa física", como ocorrera em Roda Viva - na época, uma enorme ofensa, diferente do que acontece na montagem atual, pois a recepção foi modificada em cinquenta anos:

\footnotetext{
Imitação e indignação, levadas ao extrêmo, transformam-se uma na outra, uma guinada de grande efeito teatral, em que se encerra e expõe com força artística uma posição política. A platéia, por sua vez, choca-se três, quatro, cinco vezes com a operação, e em seguida fica deslumbrada, pois não esperava tanto virtuosismo onde supusera uma crise. Este jogo, em que a última palavra é sempre do palco, esta corrida no interior de um círculo de posições insustentáveis, é talvez a experiência principal proporcionada pelo Oficina. (SCHWARZ, 1978, p. 87)
}

Ao visitar tomadas chocantes de Roda Viva, Schwarz (1978, p. 87) advoga ali a combinação de dois itens artisticamente distintos, sexo e dinheiro, "imagens de um naturalismo de choque, caricato e moralista", relacionados à "ação direta" (crítica e cultural) exercida na plateia; no entanto, as experimentações libertárias, partilhadas com grupos como o Living Theatre, no Oficina, possuíam uma nota terrorista insultante: “O espectador é tocado para que mostre o seu medo, não seu desejo. É fixada a sua fraqueza, e não o seu impulso. Se acaso não ficar intimidado e tocar uma atriz por sua vez, causa desarranjo na cena, que não está preparada para isto." (SCHWARZ, 1978, p. 87-88).

Ainda, Schwarz (1978, p. 88) critica o procedimento de choque do Oficina - sobretudo no que concerne à sua ineficácia política de identificação empática e à contradição formal de convencionalização -, o qual, podemos supor, tem como premissa a moralidade do pensamento burguês e adquire vigor através da sua parte visual. Isso põe a companhia em diálogo direto com o que foi dito sobre engajamento por Eric Bentley (1969), segundo já 
verificamos: o Oficina prova-se engajado para a perspectiva bentleyana ao desnudar e acusar a postura confortável de uma classe social (a média, de onde também havia saído o grupo) em meio ao capitalismo industrial (ligado ao regime ditatorial no Brasil), do qual faz parte a cultura de massas, realizando tudo isso dentro do teatro e utilizando o poder demonstrativo da arte cênica:

\begin{abstract}
A dessolidarização diante do massacre, a deslealdade criada no interior da platéia são absolutas, e repetem o movimento iniciado pelo palco. Origina-se uma espécie de competição, uma espiral de dureza em face dos choques sempre renovados, em que a própria intenção política e libertária que um choque possa ter se perde e se inverte. As situações não valem por si, mas como parte de uma prova geral de força, cujo ideal está na capacidade indefinida de se desidentificar e de identificar-se ao agressor coletivo. É disto que se trata, mais talvez que da superação de preconceitos. Por seu conteúdo, este movimento é desmoralizante ao extremo; mas como estamos no teatro, ele é também imagem, donde a sua força crítica. O que nele se figura, critica e exercita é o cinismo da cultura burguêsa diante de si mesma. Sua base formal, aqui, é a sistematização do choque, o qual de recurso passou a princípio construtivo. Ora, a despeito e por causa de sua intenção predatória, o choque sistematizado tem compromisso essencial com a ordem estabelecida na cabeça de seu público, o que é justamente o seu paradoxo como forma artística. Não tem linguagem própria, tem que emprestá-la sempre de sua vítima, cuja estupidez é a regra de explosivo com que ele opera. Como forma, no caso, o choque responde à desesperada necessidade de agir, de agir diretamente sobre o público; é uma espécie de tiro cultural. Em consequência os seus problemas são do domínio da manipulação psicológica, da eficácia - a comunicação é procurada, como na publicidade, pela titilação de molas secretas - problemas que não são artísticos no essencial. Quem quer chocar não fala ao vento, a quem entretanto todo artista fala um pouco. E quem faz política, não quer chocar... (SCHWARZ, 1978, p. 88)
\end{abstract}

Por fim, questionando a contribuição do Oficina para com a esquerda, Schwarz (1978, p. 88) localiza o grupo e o vanguardismo proposto dentro da vazia ideologia burguesa e atuando de acordo com o contexto, transformando em "habitável, nauseabundo e divertido o espaço do nihilismo de após-64". Entretanto, não se pode negar o início da companhia como aliada política e o seu crescimento para cima dos poderes dominantes.

Encerrando a discussão do presente capítulo por críticas especializadas, sabemos que as colaborações da época sobre o espetáculo são dificilmente encontradas hoje em dia, mas é válido enfatizar que parte da imprensa buscou ultrapassar as questões morais de querelas com a política, procurando perceber Roda Viva enquanto acontecimento teatral, com determinados tempo, espaço e ideias. Dessa forma, embora inovadora, para uma importante crítica de Tite de Lemos (apud SILVA, 1981, p. 165-166), a encenação faria parte de um processo desencadeado por Onde Canta o Sabiá, texto de Gastão Trojeiro montado por Paulo Afonso Grisoli, em 1966, também passando por Terra em Transe no cinema e o desdobramento disso em $O$ Rei da Vela, influenciador de outras obras, mesmo que se saiba da preponderância do 
surgimento de Roda Viva no seu momento, tendo em vista a sua tamanha polemização:

Em Roda Viva... o teatro parece agonizar sob as machadadas de um bando de selvagens. O ciclo de "purificação pela carne", iniciado com o Sabiá, tem em Roda Viva o seu instante de exacerbação máxima, num espetáculo que faz explodir toda a energia erótica reprimida ao longo de muitos anos no inconsciente do teatro brasileiro.

A par disso, porém, Roda Viva é o primeiro espetáculo do ciclo a introduzir ostensivamente e a encaminhar de modo orgânico o debate em torno do raio de ação cênica do teatro. A violação deliberada dos limites físicos impostos pela geografia do palco à italiana não era em Roda Viva a mera concretização de um capricho infantil compulsivo de agressão ao espectador... Muito mais do que isso, essa desobediência era uma questão de princípio: uma tumultuada meditação acerca do próprio destino do teatro do século XX, crucificado entre a rala elite que pode pagar para ver-se desempenhada, aconchegada e petrificada em suas sólidas posições de bem-estar e a necessidade de testemunhar, verdadeira e eficazmente, contra o establishment... Roda Viva operou precisamente a radicalização que o pensamento oficial não podia tolerar, e todas as velhas gramáticas dos especialistas estabelecidos puseram-se a corar de vergonha ante os pronomes mal colocados e a mistura de tratamentos... (LEMOS, apud SILVA, 1981, p. 165-166)

É igualmente oportuno mencionar os entornos da estreia, quando, pelo Jornal do Brasil, Yan Michalski observou aquela confusão já conhecida de inúmeras fãs de Chico Buarque diante do teatro de Zé Celso, a quem o crítico atribui laivos de individualidade exacerbada:

Será difícil, aliás, encontrar uma platéia que possua reais afinidades com este happening, este ritual pagão que José Celso criou, com uma ousadia suicida, com um talento admirável, mas também com uma selvageria que desta vez me pareceu decididamente exagerada. A impressão que o espetáculo me deixou é a de que se trata, antes de mais nada, de uma catarsis particular do diretor, de sua luta pessoal contra os seus demônios interiores, com o qual o público tem muito pouco a ver. (MICHALSKI, 1968)

Dividido entre suas opiniões referentes ao malogro e aos atributos da montagem, na mesma redação, Michalski destaca a potência inicial da peça, em violência e beleza, logo encaminhando advertências ao diretor a respeito de suas finalidades chocantes (ponto explorado por Anatol Rosenfeld, como vimos), das quais o autor e o público de Roda Viva não teriam culpa alguma e que transformavam o espetáculo em um dos "mais alienantes e alienados dos últimos tempos". Evidentemente, discordamos da expressão do crítico, no intuito de desvendar incisivamente as suas características engajadas ou com potencial para tal:

[...] Roda-viva se transforma cada vez mais numa frenética sessão de exibicionismo histórico e, como tal, deixa aos poucos de atrair o interesse do espectador. É claro que este é submetido, do início até o fim, a um violentíssimo tratamento de choques; mas se esse tratamento, tão importante e saudável no teatro contemporâneo, é perfeitamente legítimo quando se quer chocar em nome de alguma coisa, ele me 
parece altamente discutível quando - como acontece aqui: existe apenas a vontade de chocar em nome do próprio choque. Não vejo, sinceramente, que tipo de enriquecimento uma tal realização pode trazer ao espectador. E não sei se no estágio atual do teatro brasileiro temos o direito de convidar os espectadores, com tanta falta de cerimônia, a nunca mais voltar ao teatro. (MICHALSKI, 1968)

Em uma crítica datada de 30 de janeiro de 1968 sobre a temporada carioca de Roda Viva, Michalski (2004, p. 111-112) aponta a carência de importância do texto de estreia de Chico Buarque, no entanto, assumindo que, ao tatear uma nova linguagem para si, o compositor soube externar suas qualidades de dramaturgo - entre elas, a preocupação cênica e a pertinência do debate - e fazer uma denúncia válida à indústria cultural, já que era um artista ilustre. Dessa maneira, a peça seria relevante como um documento com este fim. Defendendo um espetáculo "mais convencional" para a Roda Viva de Chico, na verdade apagada pelo exibicionismo de Zé Celso, Michalski (2004, p. 113) talvez não capte o desejo do autor de justamente mudar a sua doce imagem até então divulgada, combinável com suas canções; portanto, o crítico conclui confirmando a fragilidade do escrito ao ter de abarcar, para além da manifestação original, os protestos e a linguagem incutidas pelo diretor "contra o poder corruptor da televisão, contra a burguesia, contra a polícia, contra os Estados Unidos, contra a igreja e contra alguns males menores". Porém, admitindo que a montagem deu mais importância ao texto, Michalski (2004, p. 113-114) frisa o paradoxal aumento de insignificância da peça quando esta entra na roda do encenador.

Um dia depois, em uma crítica que julgamos ter maior mérito, Michalski (2004, p. 114) indica os prós e os contras da realização e, embora reconhecendo o talento de Zé Celso, faz uma grande ressalva, ligada à linha tênue entre o encanto e o exagero da obra:

\footnotetext{
O espetáculo de José Celso Martinez Correia é em grande parte frustrado; mas é, ao mesmo tempo, fascinante, pelo virtuosismo e pela beleza de muitos momentos da sua mise-en-scène, e pela inaudita violência da sua concepção.

[...] Faltou pouco para que José Celso fizesse de Roda-Viva um espetáculo inesquecível. Quando ele se limita a deixar fluir a sua inspiração, a fazer funcionar os seus raros dons de orquestrador cênico, e a inventar símbolos de irresistível força poética, Roda-Viva é uma experiência emocionante para o espectador capaz de se despir de qualquer atitude preconcebida. A empostação ritual de uma grande parte do espetáculo, apoiada num bem imaginado paralelo entre determinados ritos da liturgia católica e a trajetória do ídolo que o leva aos ápices da glória e depois ao supremo sacrifício, consegue criar, muitas vezes, um clima místico de excepcional densidade. [...] A própria selvageria primitiva da encenação, principalmente quando expressa através de inspiradas intervenções do dinâmico coro, é emocionante e bela, enquanto fica contida dentro dos limites de um fenômeno cultural e não descamba para gratuitas manifestações de histérico exibicionismo. (MICHALSKI, 2004, p. 114-115)
}

Na mesma crítica, Michalski (2004, p. 115) ataca principalmente a mistura de influências do espetáculo de Roda Viva, para ele, não bem absorvidas pela concepção cênica, 
que somente agredia e chocava as pessoas com uma montagem "infantil e simplista". O crítico ainda traz uma fala do próprio diretor sobre os seus objetivos, de chacoalhar também a esquerda, como sabemos:

“... Enquanto o método convencional de comunicação [TV] é usado para fazer o espectador esquecer-se permanentemente, eu o obrigo a participar: assinar manifesto, levar pancada da polícia, tirar mendigos de entre as pernas. Quando ele está totalmente envolvido, agarrado e atado por todos os seus mitos, eu e Chico o profanamos. Assim, em vez de um distanciamento crítico, ele leva uma bofetada. É por isso que ninguém consegue assistir ao espetáculo quieto, muda de lugar, reclama, comenta, faz o diabo. E sai de seu estado de torpor para uma reação individual. É obrigado a agir." (CORRÊA, apud MICHALSKI, 2004, p. 115, inclusão e grifos nossos)

Portanto, questionando as ordens de ação deste teatro ao seu ouvinte (sem explicações de como e quando), Michalski (2004, p. 115-116) sublinha o quanto um despertar chocante para agir, quando acontece, é momentâneo, isto é, raramente expandido ao plano social e geralmente terminado no tempo de uma apresentação, com o fim de cortar o incômodo da não participação - no limite, o maior eco de Roda Viva em sua plateia poderia ser a de afastá-la dos palcos, conforme foi visto, pois a adesão à agressão como vítima causaria estranhamento. Fora outros detalhes, por fim, o crítico elogia o aguerrido elenco, mas fica visível a sua perspectiva estigmatizadora de teatro agressivo ao generalizar o conservadorismo dos espectadores, os quais começavam a enxergar o teatro, já não mais encabeçado pelo TBC, como um espaço de subversão - de fato, as classes mais altas, visavam a uma higienização da cultura.

Por outro lado, ao qualificar Roda Viva em seu livro, Michalski (1989, p. 35) enfatiza o esforço do teatro nesse cenário desolador, trabalhando com uma raiva justificável e relacionada ao radicalismo dos movimentos estudantis:

A expressão mais incisiva dessa raiva é o espetáculo mais polêmico do ano, Rodaviva, de Chico Buarque, cuja estréia no Rio, logo no início de janeiro, desencadeia uma tempestade de protestos e de adesões entusiásticas. José Celso - desta vez numa produção independente, fora do Oficina - leva aqui mais adiante os seus conceitos de um teatro violento, agressivo e provocador, que começara a formular em $O$ rei da vela (que, por coincidência, entra em cartaz no Rio pouco antes de Roda-viva). Em termos de qualidade artística, Roda-viva é uma realização ingênua, não obstante alguns momentos de grande beleza ritualística e a magnífica música e Chico; mas a sua ousadia o credencia como um intérprete autêntico do seu tempo.

A presença simultânea em cartaz de $O$ rei da vela e Roda-viva torna evidente a existência de um novo teatro, zangado e debochado, que assusta o público tradicional e parte da crítica. Polêmicas veementes sobre a legitimidade dos princípios que o inspiram ocupam espaços significativos na imprensa. (MICHALSKI, 1989, p. 35) 
Durante a trajetória do Teatro Oficina, foi possível perceber que não houve uma teoria norteadora explícita, como foi possível estabelecer para o Teatro de Arena (com um apego mais inicial por Stanislavski e, no tempo dos musicais de protesto, por Brecht). De sua parte, o grupo da Jaceguai pesquisou e devorou de tudo um pouco, por vezes, concomitantemente, de maneira antropofágica - incluindo-se nisso a influência decisiva dos dois teatrólogos citados. Zé Celso chegou a confessar estudos de Artaud e de Grotowski em sua época presumidamente agressiva, mas não desenvolveu uma teoria a partir daí. Por consequência, podemos concluir que, desde o nascimento, o Oficina se mostrou mais aberto do que o seu conviva Arena a um repertório internacional e a tensionar os limites da arte, sendo heterogêneo em tendências e abusado cenicamente e politicamente; assim, realizou montagens inovadoras (quanto a si mesmo e à linguagem teatral), experimentou elementos épicos e cruéis e deu relevo cada vez maior para a figura de seu encenador e para a criação coletiva. Dentro disso, Roda Viva, feita a partir de um texto crítico da sociedade de consumo burguesa (o próprio público), em um tempo de lutas populares, foi um trabalho no qual esse ramo da oposição também defendeu uma ideia, contendo um engajamento particular dentro de si, pela via do que escolhemos chamar de "irracional lúcido". Sem ser considerado totalmente de esquerda, até porque tomou distância do teatro tradicionalmente engajado em algumas esferas formais - contudo, obras brasileiras revolucionárias e/ou conscientizadoras comumente são vistas como subversão esquerdista -, o espetáculo teve a preocupação de revelar o caos do contexto brasileiro por meio de um baque estético e político, fisicamente empurrando a todos para a ação social, mesmo não demonstrando claramente a sua crítica; logo, no emaranhado da multidão do coro, do fígado cru, dos palavrões e dos mitos em sequência, há quem pense que a recepção apenas se chocava, mas um caminho ficou aberto com essa "revolução" político-cultural que rendeu na forma.

Resumindo o argumento engajado da companhia, cremos que muito já se indagou sobre os influxos dessa simbólica peça na realidade prática brasileira de 1968, uma vez que a sua encenação pretendeu recriar e criticar tal conjuntura social através de contatos drásticos e então novos com o público; ao mesmo tempo, repreendeu-se em demasia a sua "ira irracional", que somente expressava um cansaço selvagem da amordaçada sociedade sessentista, atormentada antes do AI-5. Portanto, em mais uma objeção à ditadura (como o Arena já havia feito e como o próprio Oficina já teria fomentado, em termos racionais), a crítica se tornava violenta e física, política e formal, e sempre por liberdade, embora parecesse utópica. Ademais, a estética agressiva, apesar de ter sido pioneira em demonstrar uma contestação alternativa, hoje em dia é pontual: após renovações nas plateias, não de forma, mas de 
conteúdo (por exemplo, o Teatro Oficina é majoritariamente frequentado pela esquerda e pelas classes médias intelectuais), o escracho é visto hoje como uma técnica que não choca tanto e a violência como um discurso, conforme segue a realização celebratória de 2018. Nisso reside o "problema" de somente a esquerda frequentar teatro político ainda hoje: a arte continua discutindo a problemática do autoritarismo, podendo chegar a significar "pregar para convertido" - no momento, tal saída é até positiva, pois precisamos nos empolgar novamente com as nossas escolhas políticas.

Enfim, a recente remontagem de Roda Viva traz de volta a sua atmosfera, mesmo sendo uma atualização (não fiel) do espetáculo de 1968, expondo figuras políticas e artistas mistificados em nosso tempo com sua sempre ferrenha crítica, que mira em um alvo - do público progressista burguês de 1968 à classe média de direita em 2018 - querendo incomodá-lo. Transpondo isso de forma admirável, confiamos que a descolonização teatral tão desejada por Zé Celso - esteja ocorrendo nos atuais espaço cênico e recepção: todos devem se livrar daqueles paradigmas de bom, ruim e normal para adentrar o Oficina da nova Roda Viva, onde a descolonização acontece em tudo, ampliando as nossas perspectivas de entendimento do mundo e exigindo que desconstruamos o corpo e a mente (treinados ao drama burguês). O novo Roda Viva é uma festa, ao mesmo tempo libertadora e politicamente engajada. 


\section{CONCLUSÕES PARCIAIS}

Depois de evidenciar os alvos comuns dos engajamentos do Teatro de Arena e do Teatro Oficina, apesar de não nos determos no momento presente do Brasil, não devemos deixar essas obras e orientações políticas dos anos 60 - somente passíveis de existência do jeito que foram - no esquecimento, tendo em vista o período tão delicado e retrocedente pelo qual estamos passando. É necessário se engajar para não o repetir. Diante disso - e como cada capítulo anterior já teve o seu fechamento -, através de um artigo de programa de Augusto Boal e de uma entrevista de José Celso Martinez Corrêa, ambas de 1968, iremos visitar essas respectivas posições políticas, renovadas com o passar da década.

Em “A Guinada de José Celso", entrevista referenciada durante o capítulo anterior por alguns estudiosos do Oficina, o diretor conversa com Tite de Lemos sobre as profundas mudanças ocorridas no interior do coletivo (houve a passagem de um teatro essencialmente estrangeiro para um teatro brasileiro e mais agressivo com o público) e em nosso teatro desde a sua montagem de $O$ Rei da Vela, texto do modernista Oswald de Andrade estreado em 1967, sendo possível captar a euforia causada no entrevistado por conta de seu trabalho em Roda Viva, de Chico Buarque, espetáculo que, em plena carreira no ano de 1968, completava o processo de revolução desencadeado pouco antes. Em um fluxo de consciência, ao falar da eficácia do teatro de 1968 diante do panorama político, ele dá uma aula de politização na primeira resposta, apurada abaixo.

Inicialmente, Corrêa (1968, p. 116) define politicamente e ataca a recepção dos "teatros progressistas", formada pela pequena-burguesia e pela alta-burguesia estudantil, a qual, no geral, busca "[...] consumir uma justificativa da mediocridade de soluções que seu status oferece, enquanto participação na vida nacional”. Localizando-se como vítima (do militarismo, dos americanos ou da burguesia de direita), a plateia não obtém tal participação e acaba rindo ou chorando disso no teatro, o seu purgatório, conforme indica Corrêa (1968, p. 116-117) - todavia, ainda nessa etapa, quem sustenta o teatro paulistano e embasa a oposição é a audiência decorrente do Teatro Brasileiro de Comédia (TBC), "a burra e provinciana burguesia paulista" -; para ele, diferente disso, público superior é aquele que ambiciona por "pelo menos uma ideologia na cultura e não simplesmente uma badalação", embora este se aproxime do outro em sua vontade de mistificação - logo, com desmistificação e chamada de atenção ao verdadeiro posto dessa gente privilegiada (pagantes), o teatro teria um papel político determinado e não pedagógico (como cultivava o Arena), oferecendo contra desejos aos burgueses: 
O teatro tem hoje a necessidade de desmistificar, colocar êste público no seu estado original, cara a cara com sua miséria, a miséria de seu pequeno privilégio feito às custas de tantas concessões, de tantos oportunismos, de tanta castração e recalque e de tôda a miséria de um povo. O importante é colocar êste público em têrmos de nudez absoluta, sem defesa, incitá-los à iniciativa, à criação de um caminho nôvo, inédito, fora de todos os oportunismos até então estabelecidos - batizados ou não como marxistas. A eficácia política que se pode esperar do teatro para êste setor que êle atende - para a pequena burguesia - é a eficácia de ajudar a estabelecer em cada um a necessidade de iniciativa individual - a iniciativa de cada um começar a atirar sua pedra contra o absurdo brasileiro. [...] Depois de tudo, o teatro como único lugar fora das comunicações de massa, sem os entraves dos produtores e sem a necessidade de encarar o espectador como simples cifra de consumo tem que se encaminhar no sentido de despertar a iniciativa individual. [...] O teatro não pode ser um instrumento de educação popular, de transformação de mentalidades na base do bom meninismo. A única possibilidade é exatamente pela deseducação, provocar o espectador, provocar sua inteligência recalcada, seu sentido de beleza atrofiado, seu sentido de ação protegido por mil e um esquemas teóricos abstratos e que sòmente levam à ineficácia. Num momento de desmistificação, o importante é a procura de caminhos que levem a ações novas. Nêste momento portanto o sentido da inovação, da descoberta, do rompimento com o passado no campo de teatro deve ecoar, ser o reflexo e ao mesmo tempo refletir todo um esquema de projetos e de conscientização de nossa realidade. (CORRÊA, 1968, p. 117)

Defendendo, antes do conhecido teatro político de "peça bem pensante e ultra bem conceituada, cheia de verdades estabelecidas", a excitação criativa estética como propulsora de ações políticas, Corrêa $(1968$, p. 117) parece se colocar contra o que o Arena vinha fazendo por meio dos musicais, além de sugerir o engajamento de seus próprios dois últimos espetáculos. Portanto, frente à urgência de solução para o que chama de "uma situação nacional insustentável" e ao caráter hostil dos tempos de "terceira guerra mundial", Corrêa (1968, p. 118-119) advoga pela violência do teatro, esse observador do mundo, com o fim de trazer aos palcos a condição social habitual e derrotar a dormência culpada de quem o assiste:

[...] a eficácia do teatro tem que estar ligada à existência dêste mundo de violência, a tão grande distância dos caminhos do transformismo, do reformismo, da educação das massas e tudo o mais. [...] O importante não é denunciar sòmente os generais americanos. É mostrar que enquanto nós nos entregamos ao nosso oportunismo, somos os beneficiários do estado de coisas que êles nos criaram. E não adianta chorarmos ou rirmos nos teatros em que isso é mostrado. Estamos colaborando. A eficácia do teatro político hoje é o que Goddard colocou a respeito do cinema: a abertura de uma série de Vietnames no campo da cultura - uma guerra contra a cultura oficial, a cultura do consumo fácil. Com o consumo não só se vende o produto, mas também se compra a consciência do consumidor. O sentido da eficácia do teatro hoje é o sentido da guerrilha teatral. Da anticultura, do rompimento com tôdas as grandes linhas do pensamento humanista. Com todo descaramento possível, pois sua eficácia hoje sòmente poderá ser sentida como provocação cruel e total. (CORRÊA, 1968, p. 118)

Enquanto diretor, levando em consideração que não se dispõe de circos, mas de limitadas plateias pagantes, pertencentes à camada social dos artistas, Corrêa (1968, p. 119- 
120) preconiza, querendo acordá-la, "a violência da arte", não "o cartilhismo e o pedagogismo barato" dos palcos políticos, o racionalismo já desacreditado por ele e o "pequeno teatro da crueldade"; com isso, o fundador do Oficina introduz o seu discurso pelo "teatro da crueldade brasileira" e pela insurgência da "ira recalcada", dos quais tanto se falou depois do acontecimento de Roda Viva - segundo ele, a porrada incentiva a adoção de posição por parte da recepção teatral e a arte sem compromissos pode se mostrar a mais politicamente competente em uma transformação:

\begin{abstract}
Para um público mais ou menos heterogêneo que não reagirá como classe, mas sim como indivíduo, a única possibilidade é o teatro da crueldade brasileira - do absurdo brasileiro - teatro anárquico, cruel, grosso como a grossura da apatia em que vivemos. A eficácia política numa platéia que não vai se manifestar como classe não será medida pela certeza do critério sociológico de uma peça, mas pelo nível da agressividade. [...] A única possibilidade de eficácia é obrigar a se tomar posições e fazer êste país, uma ditadura de classe média, tentar sair do seu marasmo. Não se trata mais de proselitismo, mas de provocação. Cada vez mais essa classe média que devora sabonetes e novelas estará mais petrificada e no teatro ela tem que degelar, na base da porrada. Com isso, depois dêste golpe uma coisa ganhou sentido. $\mathrm{O}$ sentido de fazer a arte, a arte pela arte. Nada com mais eficácia política do que a arte pela arte, porque a arte em si é um fenômeno de criação, de descompromisso com fórmulas feitas, é sentido de reivindicação e portanto de subversão. [...] A agressividade, a violência que tem a arte é mais forte, no campo do teatro que mil manifestos redigidos dentro de tôda prudência que a política exigiria. A arte não tem compromissos e nêste país parado, onde não acontece nada, onde você passa matando o tempo e o tempo matando você, a arte sôlta e livre poderá vir a ser a coisa mais eficaz possível. [...] E todo mundo tem mêdo da arte que se fará necessàriamente agora no país. Pois ela será ameaçadora, perigosa e testemunhará, se não fôr de encomenda, tôda esta fase violenta e descarada que o Brasil e o mundo estão atravessando. [...] $\mathrm{O}$ importante é, como artistas, nos manifestarmos sem o menor preconceito dentro e fora de nosso tempo de atividades. Hoje mais do que nunca é um momento de se confiar na arte e dar uma guinada enorme. (CORRÊA, 1968, p. 119-120)
\end{abstract}

Descortinando a ideia de reação dos oportunistas progressistas, por fim, Corrêa (1968, p. 120) revela a sua descoberta do "poder de subversão da forma" artística (igualmente de conteúdo) - a qual não deve ser, mas tem sido recalcada -, mediante $O$ Rei da Vela, e anuncia a "arte brasileira violenta" do porvir, sem dúvida despertada por Oswald e pela antropofagia, com vistas à revolução: “A eficácia política é devorar tôda a mitologia dêste país.” (CORRÊA, 1968, p. 120). Após conscientizar pela violência, no restante da entrevista, o diretor se concentra em sua montagem de $O$ Rei da Vela, já visitada nesta dissertação.

Em 1968, a esquerda política aparentava acordar para a nova atualidade e se radicalizar, vendo que a ditadura havia vencido as batalhas iniciais - isso se refletia no entusiasmo das produções artísticas, principalmente das mais críticas à realidade penosa do país e da cultura, como o teatro. Nesse sentido, a arte era plural, mas geralmente alicerçada no 
desalento dos artistas com relação ao futuro da nação e da arte; assim, a diversidade de objetivação dava ensejo a reflexões inquietas como a de Boal, expressa na concepção da $1^{a}$ Feira Paulista de Opinião, ocorrida pouco antes da promulgação do ameaçador AI-5 em forma de espetáculo agregador (de obras relevantes), cujo tema foi um questionamento em cima da arte e da sociedade brasileira. Na apresentação da Feira, por meio do texto-manifesto “Que pensa você da arte de esquerda?" (posteriormente publicado como "Que pensa você do teatro brasileiro?"), o diretor coteja as diferenças da arte de esquerda posta em debate a fim de proporcionar uma conduta a ser compartilhada por todo este lado da história contra o poder do regime autoritário - perante os limites impostos logo após, companhias teatrais preocupadas com a história, como o Arena, vieram a se desfazer.

Iniciando a argumentação e em certa medida respondendo ${ }^{25}$ a Zé Celso, Boal (1979, p. 41) diz que para fazer frente à cisão da esquerda, ambicionada pela direita reacionária, e à consequente derrocada de si mesmos, os artistas esquerdistas ("nós - festivos, sérios ou sizudos") devem ficar alertas, mesmo desejando mudanças culturais e sociais ligeiramente distintas umas das outras: "Nós que, em diferentes graus, desejamos modificações radicais na arte e na sociedade, devemos evitar que diferenças táticas de cada grupo artístico se transformem numa estratégia global suicida." (BOAL, 1979, p. 41). Por outro lado, embora não denote a força maior de uma das correntes - a serem superadas - e sempre anteveja a finalidade artística e cidadã de contrariar o estado das coisas, Boal (1979, p. 41) esclarece que não se pode escamotear as discrepâncias existentes no seio da arte de esquerda, pois as suas linhas são compreendidas quando equiparadas: "Dentro da esquerda, portanto, toda discussão será válida sempre que sirva para apressar a derrota da reação. [...] Assim, antes que a esquerda artística se agrida a si mesma deve procurar destruir todas as manifestações direitistas." (BOAL, 1979, p. 41).

Enxergando a calamidade do repertório contemporâneo a si, permeado por um teatro de inverdades (ou de alienações criminosas), Boal (1979, p. 41) expõe a cega avidez deste pelo mercado de consumo - "O dinheiro, este sim, é o verdadeiro demiurgo do gosto artístico posto em prática." - e dá as coordenadas para uma renovada esquerda ir em direção ao povo legítimo, já que considera o consumidor da arte como o definidor da forma e do conteúdo das

\footnotetext{
${ }^{25}$ É notório que, em 1968, Boal estava se radicalizando com o Arena (cada vez mais longe dos ex-CPC, dentre os quais alguns haviam se rendido ao "apelo comercial" com o Opinião e queriam participar da frente ampla junto ao Partido Comunista, como fez Vianinha); o Oficina, nesse ponto, já havia se radicalizado, montando duas peças brasileiras. Para o Arena, a pedra de toque é uma obra de 1965, cuja forma de engajamento foi criticada por Zé Celso em 1968. De certa forma, Boal também o reprovou em 1968, na Feira, colocando os tropicalismos e os imperialismos no mesmo balaio. O importante é ver que o Oficina, em seu empenho político, não estava preocupado com a recuperação do comunismo, apesar de se importar com a democracia e a liberdade nela implicadas.
} 
obras:

\begin{abstract}
O mercado consumidor de teatro é, em última análise, o fator determinante do conteúdo e da forma da obra de arte, da arte-mercadoria. E esse mercado, nos principais centros urbanos do país, é formado pela alta classe média, e daí para cima. O povo e a sua temática estão aprioristicamente excluídos. Este fato grave tem deformado a perspectiva criadora da maioria dos nossos artistas que se atrelam aos desejos mais imediatos da "corte burguesa", da qual se tornam servís palhaços, praticando um teatro de classe, isto é, um teatro da classe proprietária, da classe opressora. A consequiência lógica é uma arte de opressão.

Assim, o primeiro dever da esquerda é o de incluir o povo como interlocutor do diálogo teatral. E, quando falo povo, mais uma vez falo concretamente: "povo" é aquela gente de pouca carne e osso que vive nos bairros e trabalha nas fábricas, são aqueles homens que lavram a terra e produzem alimentos e são aqueles que desejam trabalhar e não encontram emprego. Nenhum destes freqüenta os teatros das cinelândias e, portanto é necessário fazer com que o teatro freqüente os circos, as praças públicas, os estádios, os adros, os descampados em cima de caminhões. A inclusão sistemática dessas platéias fará mudar o conteúdo e a forma do teatro brasileiro. Não basta que o Teatro de Arena de São Paulo e outros poucos elencos se disponham a fazê-lo como têm sempre feito: é necessário que toda a esquerda o faça, e que o faça constantemente. (BOAL, 1979, p. 41)
\end{abstract}

Concernente aos elogiados tempos dos Centros Populares de Cultura (CPCs), de quem se aproxima, Boal (1979, p. 41-42) conta que o interesse do povo por arte espantou a direita e que o fato de a popularização teatral inexistir nos "planos de auxílio" governamentais atuais teria a ver com os benefícios dela causados no povo - chega-se a ter estudantes nas plateias, algo insuficiente, uma vez que, para o diretor, o teatro socialmente transformador precisa ser proporcionado aos agentes da sua transformação.

Como sabemos, no geral, o teatro primeiramente resistiu à violência decretada no golpe de 1964 também com violência, segundo Boal (1979, p. 42), que montou seus musicais de protesto logo em seguida: "Variava a forma, o estilo, o gênero, mas a essência era a mesma exortação, o mesmo berro: esta era a única arma de que dispunha o teatro. As forças populares estavam desarmadas e não puderam assim, com arte apenas, vencer as metralhadoras." (BOAL, 1979, p. 42). Dessa forma, Boal (1979, p. 42) informa que a homogeneidade da esquerda artística se desmantelou depois, dando origem a três tendências fundamentais dentro do seu teatro restante, as quais devem ser superadas por meio de um embate em conjunto contra "o teatro burguês".

A princípio, Boal (1979, p. 42) descreve "O Neo-Realismo" teatral, já experimentado pelo Arena, veia que se esforça em "mostrar a realidade como ela é" através da vida do povo brasileiro e da forma genuína. Contudo, a esse tipo de teatro impõe-se o desafio de não acarretar uma "empatia filantrópica" no público, como denominaria Anatol Rosenfeld, isto é, uma espécie de esmola ou caridade, conforme Boal (1979, p. 42): 
O realismo enfrenta, de início, um obstáculo principal: o diálogo não pode transcender nunca o nível de consciência do personagem; este nada dirá ou fará que não possa ser feito ou dito na realidade desse próprio personagem. E como na maioria dos casos, os camponeses, operários ou lumpens retratados não têm verdadeira consciência dos seus problemas - daí resulta que os espectadores ficam empaticamente ligados a personagens que ignoram sua verdadeira situação e os verdadeiros meios de superá-la. Essas peças, portanto, tendem a transmitir apenas mensagens de desesperos, perplexidades e dores.

Trazendo o exemplo de Eles não usam black-tie, Boal (1979, p. 42) ainda reconhece a possibilidade de criação de personagens conscientes, mas lembra da relevância "mais documental do que combativa" (a última seria mais necessária) do realismo, ao exibir "a vida brasileira".

Muito presente no Arena daquela época, a segunda corrente explicada por Boal (1979, p. 42) é a "Sempre de Pé", ou exortativa, a qual usa fábulas maniqueístas com o fim de exprimir a realidade, visando politicamente ao combate da opressão; porém, a audiência suscitada por tal teatro estaria na base daquela opressão. Então, para não incorrermos em falência, o povo deve ser o interlocutor dessa verdade. O autor é categórico:

O teatro "sempre de pé" só tem validade no convívio popular.

A exortação, os processos maniqueístas, as caracterizações de "grosso modo", as simplificações analíticas gigantescas, foram também constantes nos espetáculos dos CPCs. Esta é a linguagem do teatro popular. A verdade não era nunca tergiversada apenas a sua apresentação era simplificada. (BOAL, 1979, p. 42)

Com sinceridade, Boal (1979, p. 43) defende o maniqueísmo, utilizado por ele em Arena Conta Zumbi, como vimos: para o diretor, a técnica é primordial nessas peças, sendo muitos dos seus inimigos de direita apoiadores de uma duvidosa neutralidade (a igualdade de maldade e bondade de todos os homens). Consequentemente, Boal (1979, p. 43) reafirma a validade dos métodos apresentados e volta a sublinhar o povo enquanto "o verdadeiro interlocutor deste tipo de teatro", a ser feito nas praças públicas e, como ferramenta, pela boa transformação social.

Por último, Boal (1979, p. 43) aborda a linha "Chacrinha e Dercy de Sapato Branco", ou "o tropicalismo chacriniano-darcinesco-neo-romântico", cujos representantes não se acusaram claramente e nem elucidaram os seus objetivos. Referente a isso, Boal (1979, p. 43) traz uma série de trechos da entrevista histórica de Zé Celso (sem nomeá-lo) como exemplos da falta de noção das alegações do movimento, denunciando-o: 
na rua, e portanto, prisioneiro de sua platéia burguesa, vocifera. Mas ao mesmo tempo resvala perigosamente para o reacionarismo quando (sem perceber que seus interlocutores são apenas e tão somente a burguesia) pede ao teatro burguês que incite a platéia burguesa a tomar iniciativas individuais... (BOAL, 1979, p. 43)

Mesmo sem conseguir definir o Tropicalismo, posto entre o tudo e o nada, Boal (1979, p. 43) - apesar do fortalecimento do retrocesso, levado a cabo pelos traços mais comuns do segmento - identifica o diálogo despertado e os deslocamentos positivos provocados por ele no Oficina. Portanto, para Boal (1979, p. 43-44), o Tropicalismo é negativamente "neoromântico", "homeopático", "inarticulado", "tímido e gentil" e "importado", sendo mais prejudicial do que tudo a sua carência de lucidez, associada à falta de fixação de posições:

Esta terceira tendência do teatro brasileiro atual é a mais caótica e é, também, aquela que, tendo sua origem na esquerda mais se aproxima da direita. Sabemos que os seus principais integrantes não renunciam à condição de artistas porta-vozes do povo. Mas não ignoramos, também, o perigo que corre todo e qualquer movimento que teme definições. (BOAL, 1979, p. 44)

Ao final, Boal (1979, p. 44) conclui pela falta de abertura para trocas entre as tendências apresentadas, visto que as classes sociais seriam impenetráveis e que a aparente democracia foi desmistificada com a ditadura; logo, perante as dificuldades da cultura, a verdade e o povo (buscados na Feira) são a salvação do quadro de realidade mais recente:

\footnotetext{
Maniqueísta foi a ditadura. Contra ela e contra os seus métodos deve-se maniqueisticamente levantar a arte de esquerda no Brasil. É preciso mostrar a necessidade de transformar a atual sociedade; é necessário mostrar a possibilidade dessa mudança e os meios de mudá-la. E isto deve ser mostrado a quem pode fazê-lo. Basta de criticar as platéias de sábado - deve-se agora buscar o povo.

[...] Necessário, agora, é dizer a verdade como é. [...] É necessário pesquisar nossa realidade segundo ângulos e perspectivas diversas: aí estará seu movimento. Nós, dramaturgos, compositores, poetas, caricaturistas, fotógrafos, devemos ser simultaneamente testemunhas e parte integrante dessa realidade. (BOAL, 1979, p. 44)
}

Assim, vemos que o manifesto, clarificando os três tipos de arte de esquerda daquele momento socialmente complicado, mostra muito bem o tom do engajamento do diretor do Arena em 1968, sobretudo apontado contra a arte de direita e os tropicalistas (incluindo o Oficina). Adotando a posição delineada, Boal se dedicou ao Teatro do Oprimido na década de 1970, após o fechamento da sua companhia.

Atentando para o final da década de 1960, quando Arena e Oficina encabeçavam o teatro paulista de oposição renovadora, Arantes (1981, p. 36) nota as disputas entre eles, em termos políticos e formais, ocasionando as escolhas por públicos: 


\begin{abstract}
A escolha de um público é decorrência necessária, pois nenhum dos dois grupos admite estar produzindo sob medida: ambos têm em comum a crença de que são portadores de verdades das quais o público carece e as quais devem expor, maniqueisticamente ou na base da porrada. Verdades diferentes, públicos diferentes, mas o mesmo modo de conceber a relação entre produtores e consumidores [...]. Assim, não é o consumidor que determina a forma e o conteúdo do produto legítimo, mas é o produto legítimo, e porque é legítimo, que escolhe seu consumidor. É certo que a relação produtor/consumidor aparece sob formas bem diferentes para Arena e Oficina, mas ambos coincidem na proposta de uma produção que é progressista porque não se subordina às leis de mercado, e como tal pode ser portadora de uma verdade. (ARANTES, 1981, p. 36)
\end{abstract}

Sem ignorar as demandas do mercado progressista, Arantes (1981, p. 36-37) sustenta, já nos anos 80, que se deve considerar os "os efeitos de seu jogo na produção, distribuição e consumo de produtos culturais" - ele coteja as representações feitas pelas duas companhias mencionadas, com suas respectivas consciências, da criação "estético-política" e da ligação com a recepção. Assim, salientando a complementaridade dessas propostas descombinadas, Arantes (1981, p. 40) diz que haveria uma mesma crença, referente à "eficácia política direta do teatro sobre o conflito social", ou seja, ambas viam no teatro um veículo de verdades, acatadas pela plateia a ser influenciada:

Ao Arena interessa contribuir para o desencadeamento de uma ação eficaz de
oposição; [...] o público correto é aquele que já é um exército em guerra, embora não
o saiba, sendo assim necessário tratá-lo como tal, despertar seus valores
adormecidos e apontar-lhe o inimigo a ser vencido (exortação e maniqueísmo). O
Oficina enfrenta a missão, um pouco mais árdua e antipática, de desmistificar as
ilusões dos que se julgam os verdadeiros soldados, colocá-los em nudez absoluta e
despertar a necessidade da ação individual. Daí decorrem técnicas diferentes: no
Arena todos os recursos que possam romper qualquer consenso entre o público e a
cena. Comentava-se na época que a diferença fundamental entre Arena e Oficina era
que Boal amava seu público, enquanto J. Celso o odiava. O fato é que,
independentemente dos sentimentos dos dois diretores, o público afluiu em massa às
duas casas de espetáculos. E, o que talvez merecesse maior atenção, era
essencialmente o mesmo público. (ARANTES, 1981, p. 40)

Enfim, argumentando a favor de uma definição engajada menos limitadora e mais política (à esquerda), é possível reafirmar o engajamento de Arena e Oficina através das obras de arte mimética estudadas, até porque Roda Viva incomodou tanto as autoridades políticas e os valores sociais estabelecidos quanto Arena Conta Zumbi (e até mais, em termos de protesto), do grupo mais conhecido como engajado. Sem longas reiterações, conclui-se que as duas peças sucedem a chamada crise de público, contando com praticamente a mesma plateia; logo, há conexão entre essa "morte" do teatro (antevista por Boal em 1966 e exposta com Arena Conta Tiradentes) e o surgimento de novas tendências, assumidas pelo Oficina e só 
encaradas pelo Arena na ocasião da Feira. Por sua vez, identificando recepção teatral e mercado consumidor, Zé Celso era contrário à chamada "ditadura de classe média" na cultura e a um teatro conscientizador dessa camada (da deleitosa "esquerda festiva"), defendendo a apresentação de espetáculos feitos "na base da porrada" para desmistificar as consciências, provocar as pessoas e não recalcar as criações, reivindicando um teatro de manifestação das mazelas postas sob privilégios e incentivando uma nova oferta. Ambos questionadores do período estudado, podemos sugerir que, ao passo que o Arena constituiu um teatro de ideias atrás das trincheiras, o Oficina propôs a experiência corporal de comportamentos sociais inconformados. Diversamente, os teatros engajados de Boal e Zé Celso tomaram novos caminhos nos anos 70, tornando-se mais radicais ou experimentais, porém, o "povo" continuou distanciado de Arena e Oficina, pois em ambos o público era massivamente formado por estudantes e pela classe média frequentadora de teatro, havendo, no máximo, revolução em termos de costumes no seio desta mesma classe. 


\section{REFERÊNCIAS}

ADORNO, Theodor Wiesengrund. Engagement. In: ADORNO, Theodor Wiesengrund. Notas de literatura. Rio de Janeiro: Tempo Brasileiro, 1973. p. 50-71.

ALMADA, Izaías. Teatro de Arena: uma estética de resistência. São Paulo: Boitempo editorial, 2004.

APOlinÁRIO, João. A crítica de João Apolinário: memória do teatro paulista de 1964 a 1971, volume 1. Organização Maria Luiza Teixeira Vasconcelos. São Paulo: Imagens Conteúdo \& Forma, 2013.

ARANTES, Urias Corrêa. Arena e Oficina: Cenocracia? Arte em Revista, São Paulo, n. 6, p. 36-42, out. 1981.

AUGUSTO, Sérgio. Peça era uma alegoria do autoritarismo. Folha de S. Paulo, São Paulo, ano 73, n. 23481, 17 jul. 1993, Folha Ilustrada, p. 4-4.

BENTLEY, Eric. O teatro engajado. In: BENTLEY, Eric. O teatro engajado. Rio de Janeiro: Zahar editores, 1969. p. 150-178.

BOAL, Augusto. Hamlet e o filho do padeiro. São Paulo: Cosac Naify, 2000.

BOAL, Augusto . Que pensa você do teatro brasileiro? Arte em Revista, São Paulo, n. 2, p. 40-44, jul./ago. 1979.

BOAL, Augusto. Teatro do oprimido e outras poéticas políticas. São Paulo: Cosac Naify, 2013.

BOAL, Augusto. Tentativa de análise do desenvolvimento do teatro brasileiro. Arte em Revista, São Paulo, n. 6, p. 8-10, out. 1981.

BOAL, Augusto; CORRÊA, José Celso Martinez. Depoimentos sobre o teatro brasileiro hoje: Augusto Boal, José Celso Martinez Corrêa. aParte, São Paulo: TUSP, n. 1, p. 17-26, mar./abr. 1968.

BOAL, Augusto; GUARNIERI, Gianfrancesco. Arena Conta Zumbi. Revista de Teatro da SBAT (Sociedade Brasileira de Autores Teatrais), Rio de Janeiro, n. 378, p. 31-59, nov./dez. 1970.

BOAL, Augusto; GUARNIERI, Gianfrancesco. Vivemos um tempo de guerra. Programa do espetáculo Arena Conta Zumbi. São Paulo, 1965.

BORGES, Stephanie da Silva. Machado e Chico: dois dramaturgos no espelho da história. 2012. Trabalho de Conclusão de Curso (Licenciatura em Letras) - Instituto de Letras, Universidade Federal do Rio Grande do Sul, Porto Alegre, 2012. Disponível em: http://hdl.handle.net/10183/56152. Acesso em: 8 mar. 2019. 
BRECHT, Bertold. Estudos Sobre Teatro. Tradução de Fiama Pais Brandão. 2. ed. Rio de Janeiro: Nova Fronteira, 2005.

BRITO, Terezinha Maria de; PEREIRA, João Batista. Roda mundo, roda gigante: Roda-Viva e as imagens da indústria cultural. In: MACIEL, Diógenes André Vieira; ANDRADE, Valéria (org.). Por uma militância teatral: estudos de dramaturgia brasileira do séc. XX. Campina Grande: Bagagem / João Pessoa: Idéia, 2005. p. 167-183.

BUARQUE, Chico. Como falar ao povo? [Entrevista]. Veja, São Paulo, n. 517, p. 70-72, 2 ago. 1978.

BUARQUE, Chico; CORREAA, José Celso Martinez [Entrevista]. Programa do espetáculo Roda Viva. São Paulo, 1968.

BUARQUE, Chico; PONTES, Paulo. Gota d'água (Uma tragédia brasileira). Rio de Janeiro: Civilização Brasileira, 2009.

BYLAARDT, Cid Ottoni. Arte engajada e arte autônoma no pensamento de Theodor Adorno. Pandaemonium Germanicum, São Paulo, v. 16, n. 22, p. 84-100, dez. 2013. Disponível em: https://www.revistas.usp.br/pg/article/view/80105/83987. Acesso em: 22 jan. 2018.

CAMPOS, Cláudia de Arruda. Zumbi, Tiradentes (e outras histórias contadas pelo Teatro de Arena de São Paulo). São Paulo: Perspectiva; Editora da Universidade de São Paulo, 1988.

CANDIDO, Antonio. Literatura e Subdesenvolvimento. In: CANDIDO, Antonio. A educação pela noite \& outros ensaios. São Paulo: Ática, 1989. p. 140-162.

CIVILIZAÇÃO BRASILEIRA. Rio de Janeiro: Editora Civilização Brasileira, ano IV, n. 15, jul. 1968.

CORRÊA, José Celso Martinez. A, E, I, U, Ó - A história do Oficina. Arte em Revista, São Paulo, n. 6, p. 44-46, out. 1981.

CORRÊA, José Celso Martinez. A Guinada de José Celso - Entrevista a Tite de Lemos. [Entrevista concedida a] Tite de Lemos. Civilização Brasileira, Rio de Janeiro, ano IV, n. 15, p. 115-129, jul. 1968.

CORRÊA, José Celso Martinez. Depoimento de José Celso Martinez Corrêa - Exposição Rever Espaços, Centro Cultural São Paulo. FLÁVIO IMPÉRIO, Seção Roda Viva, 1983. Disponível em: http://www.flavioimperio.com.br/galeria/508075/508084. Acesso em: 20 de fevereiro de 2019.

CORRÊA, José Celso Martinez. Encontros. Organização Karina Lopes e Sergio Cohn. Rio de Janeiro: Beco do Azougue, 2008.

CORRÊA, José Celso Martinez. Oficina. Arte em Revista, São Paulo, n. 1, p. 61. 1979.

CORRÊA, José Celso Martinez. O tempo rodou num instante: Entrevista com Zé Celso Martinez Corrêa. [Entrevista concedida a] Nina Nussenzweig Hotimsky. Traulito, São Paulo, n. 5, p. 4-9, abr. 2012. 
COSTA, Iná Camargo. A hora do teatro épico no Brasil. 2. ed. São Paulo: Expressão Popular, 2016.

CURRICULUM. TEATRO OFICINA, São Paulo, 15 mar. 2008. Disponível em: http://teatroficina.com.br/curriculum/. Acesso em: 22 de fevereiro de 2019.

DENIS, Benoît. Literatura e engajamento: de Pascal a Sartre. Tradução de Luiz Dagobert de Aguirra Roncari. Bauru, SP: EDUSC, 2002.

DIONYSOS. Rio de Janeiro: SNT, n. 24, out. 1978.

DIONYSOS. Rio de Janeiro: SNT, n. 26, jan. 1982.

EGG, André; FREITAS, Artur; KAMINSKI, Rosane (org.). Arte e política no Brasil: modernidades. 1. ed. São Paulo: Perspectiva, 2014.

FARIA, Alexandre. Um tiro no Sabiá. CHICO BUARQUE, Seção Crítica - Roda Viva, 1999. Disponível em: http://www.chicobuarque.com.br/critica/crit_roda_faria.htm. Acesso em: 20 de fevereiro de 2019.

FARIA, João Roberto. O teatro na estante: estudos sobre dramaturgia brasileira e estrangeira. São Paulo: Ateliê Editorial, 1998.

FARIA, João Roberto (dir.); GUINSBURG, J.; FARIA, João Roberto (ed.). História do Teatro Brasileiro - volume 2: do modernismo às tendências contemporâneas. São Paulo: Perspectiva; Edições SESCSP, 2013.

FAVARETTO, Celso. Tropicália, alegoria, alegria. 4. ed. Cotia, SP: Ateliê Editorial, 2007.

FERNANDES, Rinaldo de (org.). Chico Buarque do Brasil: textos sobre as canções, o teatro e a ficção de um artista brasileiro. Rio de Janeiro: Garamond, 2004.

FERNANDES, Rofran. Roda Viva. In: FERNANDES, Rofran. Teatro Ruth Escobar: 20 anos de resistência. São Paulo: Global editora, 1985. p. 65-69.

FIGURELLI, Roberto. Sartre e a literatura engajada. Revista Letras, Curitiba, v. 36, p. 89111, 1987. Disponível em: https://revistas.ufpr.br/letras/article/view/19255/12544. Acesso em: 22 jan. 2018.

FRANCIS, Paulo. Teatro paulista - De Guarnieri a Jorge Andrade. Revista Senhor, Rio de Janeiro, n. 41, p. 73-75, jul. 1962.

GIRON, Luís Antônio. Comando de Caça aos Comunistas diz como atacou 'Roda Viva' em 68. Folha de S. Paulo, São Paulo, ano 73, n. 23481, 17 jul. 1993, Folha Ilustrada, p. 4.

GIRON, Luís Antônio. Seleção soviética inspirou nome do CCC. Folha de S. Paulo, São Paulo, ano 73, n. 23481, 17 jul. 1993, Folha Ilustrada, p. 4-4. 
GOLDFEDER, Sonia. Teatro de Arena e Teatro Oficina - o político e o revolucionário. 1977. Dissertação (Mestrado em Ciências Sociais) - Instituto de Filosofia e Ciências Humanas, Universidade Estadual de Campinas, Campinas, 1977. Disponível em: http://repositorio.unicamp.br/jspui/handle/REPOSIP/279099. Acesso em: 7 nov. 2018.

GOMES, Dias. O Engajamento é uma Prática de Liberdade. Civilização Brasileira, Rio de Janeiro, ano IV, n. 15, p. 7-17, jul. 1968.

GUARNIERI, Gianfrancesco. Entrevista com Gianfrancesco Guarnieri. In: PEIXOTO, Fernando. Teatro em movimento. São Paulo: Hucitec/Secretaria de Estado da Cultura, 1985. p. $44-60$.

GUARNIERI, Gianfrancesco. Gianfrancesco Guarnieri - Depoimento. [Entrevista concedida a] Décio de Almeida Prado, Flávio Rangel, Mario Masetti e Miriam Muniz. In: ALMEIDA, Abílio Pereira et al. Depoimentos V. Rio de Janeiro: SNT, 1981a. p. 62-92.

GUARNIERI, Gianfrancesco. O teatro como expressão da realidade nacional. Arte em Revista, São Paulo, n. 6, p. 6-7, out. 1981b.

GUIMARÃES, Frederico Moreira. Literatura e engajamento em Sartre: um estudo de Que é a literatura? 2010. Dissertação (Mestrado em Filosofia) - Pontifícia Universidade Católica de São Paulo, São Paulo, 2010. Disponível em: https://tede2.pucsp.br/handle/handle/11841. Acesso em: 21 jan. 2018.

GULLAR, Ferreira. Cultura posta em questão, Vanguarda e subdesenvolvimento: ensaios sobre arte. Rio de Janeiro: José Olympio, 2002.

HOLlANDA, Chico Buarque de. Roda Viva. Rio de Janeiro: Editora Sabiá, 1968.

IMPÉRIO, Flávio. Depoimento de Flávio Império a Margot Milleret. FLÁVIO IMPÉRIO, Seção Arena Conta Zumbi, 1985. Disponível em: http://www.flavioimperio.com.br/galeria/507872/507876. Acesso em: 20 de fevereiro de 2019.

IMPÉRIO, Flávio. Trecho de entrevista de Flávio Império a Maria Thereza Vargas e Mariângela Alves de Lima - Exposição Rever Espaços, Centro Cultural São Paulo. FLÁVIO IMPÉRIO, Seção Roda Viva, 1983. Disponível em: http://www.flavioimperio.com.br/galeria/508075/508079. Acesso em: 20 de fevereiro de 2019.

IORI, Cristina. Zé Celso, e sua nova Roda Viva. Jornal da Tarde, São Paulo, p. 18 - A, 22 nov. 1985.

LESSA MATTOS, David José. Entrevista com David José. In: ALMADA, Izaías. Teatro de Arena: uma estética de resistência. São Paulo: Boitempo editorial, 2004. p. 109-115.

LUIZ, Macksen. O cru e o cozido no teatro de agressão. Jornal do Brasil, Rio de Janeiro, ano XCVI, n. 145, p. 7, 31 jul. 1986.

MACIEL, Diógenes André Vieira; ANDRADE, Valéria. Da militância teatral num universo de letras. In: MACIEL, Diógenes André Vieira; ANDRADE, Valéria (org.). Por uma militância 
teatral: estudos de dramaturgia brasileira do séc. XX. Campina Grande: Bagagem / João Pessoa: Idéia, 2005. p. 7-15.

MACIEL, Luiz Carlos. Geração em transe: memórias do tempo do tropicalismo. Rio de Janeiro: Nova Fronteira, 1996.

MACIEL, Luiz Carlos. Quem é quem no teatro brasileiro. Civilização Brasileira, Rio de Janeiro, ano IV, n. 15, p. 49-68, jul. 1968.

MAGALDI, Sábato. Panorama do Teatro Brasileiro. São Paulo: Difusão Européia do Livro, 1962.

MAGALDI, Sábato. Um palco brasileiro: o Arena de São Paulo. São Paulo: Brasiliense, 1984.

MANDAGARÁ, Pedro. Engajamento e "engajamento" - Sartre, Adorno e Augusto de Campos. Todas as Letras - Revista de Língua e Literatura, São Paulo, v. 19, n. 2, p. 47-57, mai./ago. 2017.2 Disponível em: http://editorarevistas.mackenzie.br/index.php/tl/article/view/9239/6603. Acesso em: 22 jan. 2018.

MARTINEZ CORRÊA, José Celso. Primeiro ato: cadernos, depoimentos entrevistas (19581974). Seleção, organização e notas Ana Helena Camargo de Staal. São Paulo: Editora 34, 1998.

MICHALSKI, Yan. Primeira Crítica. CHICO BUARQUE, Seção Crítica - Roda Viva, jan. 1968. Disponível em: http://www.chicobuarque.com.br/critica/crit_roda_yan.htm. Acesso em: 20 de fevereiro de 2019.

MICHALSKI, Yan. O teatro sob pressão: uma frente de resistência. Rio de Janeiro: Jorge Zahar, 1989.

MICHALSKI, Yan. Reflexões sobre o teatro brasileiro no século XX. Organização Fernando Peixoto. Rio de Janeiro: Funarte, 2004.

MOREIRA, Mayara Franca. Em torno da literatura engajada: Sartre e o debate estético. 2012. Trabalho de Conclusão de Curso (Bacharelado e Licenciatura em Filosofia) - Instituto de ciências Humanas, Universidade de Brasília, Brasília, 2012. Disponível em: http://bdm.unb.br/handle/10483/4033. Acesso em: 20 jan. 2018.

MOSTAÇO, Edélcio. Teatro e política: Arena, Oficina e Opinião (uma interpretação da cultura de esquerda). São Paulo: Proposta Editorial, 1982.

NANDI, Itala. Teatro Oficina: onde a arte não dormia. Rio de Janeiro: Nova Fronteira, 1989.

NAPOLITANO, Marcos. A arte engajada e seus públicos (1955/1968). Revista Estudos Históricos, Rio de Janeiro, v. 2, n. 28, p. 103-124, jul./dez. 2001. Disponível em: http://bibliotecadigital.fgv.br/ojs/index.php/reh/article/view/2141/1280. Acesso em 22 jan. 2018. 
NAPOLITANO, Marcos. Coração Civil: a vida cultural brasileira sob o regime militar (19641985) - ensaio histórico. São Paulo: Intermeios: USP - Programa de Pós-Graduação em História Social, 2017. (Coleção entre(H)istória)

PARANHOS, Kátia Rodrigues. História \& teatro, teatro \& história: uma relação tão delicada (History \& theater, theater \& history: a delicate relationship). O eixo e a roda: Revista de Literatura Brasileira, Belo Horizonte, v. 26, n. 2, p. 187-205, ago. 2017. Disponível em: http://www.periodicos.letras.ufmg.br/index.php/o_eixo_ea_roda/article/view/11534/10601.

Acesso em: 22 jan. 2018.

PEIXOTO, Fernando. Teatro oficina (1958-1982): Trajetória de uma Rebeldia Cultural. São Paulo: Brasiliense, 1982.

PRADO, Décio de Almeida. Exercício Findo. São Paulo: Perspectiva, 1987.

PRADO, Décio de Almeida. O Teatro Brasileiro Moderno. São Paulo: Perspectiva, 2009.

PROJETO Balanço Geral. Programa do espetáculo Roda Viva. São Paulo, 1985.

RABELO, Adriano de Paula. A melodia, a palavra, a dialética: o teatro de Chico Buarque. 1999. Dissertação (Mestrado em Literatura Brasileira) - Faculdade de Filosofia, Letras e Ciências Humanas, Universidade de São Paulo, São Paulo, 1999. Disponível em: http://www.teses.usp.br/teses/disponiveis/8/8149/tde-03052007-

162030/publico/DissertacaoAdriano.pdf. Acesso em: 10 jan. 2019.

RIDENTI, Marcelo. Em busca do povo brasileiro: Artistas da revolução, do CPC à era da TV. Rio de Janeiro: Record, 2000.

'RODA Viva' prova que ainda é transgressiva. Folha de S. Paulo, São Paulo, ano 65, n. 20686, 21 nov. 1985, Folha Ilustrada, p. 41.

ROSENFELD, Anatol. O mito e o herói no moderno teatro brasileiro. São Paulo: Perspectiva, 1982.

ROSENFELD, Anatol. O teatro agressivo. In: ROSENFELD, Anatol. Texto/Contexto I. São Paulo: Perspectiva, 1996. p. 45-57.

ROSENFELD, Anatol. O Teatro Épico. São Paulo: Perspectiva, 1985.

ROUX, Richard. Le Théâtre Arena. Aix: Université de Provence, 1991.

SARTRE, Jean-Paul. Que é literatura? Tradução de Carlos Felipe Moisés. Petrópolis, RJ: Vozes, 2015.

SCHWARZ, Roberto. Cultura e Política: de 1964 a 1969 - Alguns esquemas. In: SCHWARZ, Roberto. O pai de família e outros estudos. Rio de Janeiro: Paz e Terra, 1978. p. 61-92.

SILVA, Armando Sérgio da. Oficina: do teatro ao te-ato. São Paulo: Perspectiva, 1981. 
TAVARES, Renan. Teatro Oficina de São Paulo: seus dez primeiros anos [1958-1968]. São Caetano do Sul, SP: Yendis Editora, 2006.

TEATRO Oficina. TROPICÁLIA, Seção Ruídos pulsativos: Geléia geral. Disponível em: http://tropicalia.com.br/ruidos-pulsativos/geleia-geral/teatro-oficina. Acesso em: 22 de fevereiro de 2019.

TELES, Edson; SAFATLE, Vladimir (org.). O que resta da ditadura: a exceção brasileira. São Paulo: Boitempo, 2010.

TOLEDO, Paulo V. Bio. Debates sobre teatro e sociedade após o golpe de 1964: reflexão e trabalho teatral de José Celso Martinez Corrêa e Augusto Boal. 2018. Tese (Doutorado em Artes Cênicas) - Escola de Comunicações e Artes, Universidade de São Paulo, São Paulo, 2018. Disponível em: http://www.teses.usp.br/teses/disponiveis/27/27156/tde-17072018170648/publico/PauloViniciusBioToledo.pdf. Acesso em: 7 nov. 2018.

VENTURA. Zuenir. 1968: o que fizemos nós. São Paulo: Planeta do Brasil, 2008.

VIANNA FILHO, Oduvaldo. Um pouco de pessedismo não faz mal a ninguém. Civilização Brasileira, Rio de Janeiro, ano IV, n. 15, p. 69-78, jul. 1968.

VIANNA FILHO, Oduvaldo. Vianinha: teatro, televisão, cinema. Seleção, organização e notas: Fernando Peixoto. 2. ed. São Paulo: Brasiliense, 1983. 